Florida International University

FIU Digital Commons

$11-5-2018$

\title{
Economic Development on U.S. Native American Reservations: A Case Study of the Tribes of Florida
}

Diane Benitez

dbeni005@fiu.edu

Follow this and additional works at: https://digitalcommons.fiu.edu/etd

Part of the Public Administration Commons, and the Public Policy Commons

\section{Recommended Citation}

Benitez, Diane, "Economic Development on U.S. Native American Reservations: A Case Study of the Tribes of Florida" (2018). FIU Electronic Theses and Dissertations. 3910.

https://digitalcommons.fiu.edu/etd/3910

This work is brought to you for free and open access by the University Graduate School at FIU Digital Commons. It has been accepted for inclusion in FIU Electronic Theses and Dissertations by an authorized administrator of FIU Digital Commons. For more information, please contact dcc@fiu.edu. 
FLORIDA INTERNATIONAL UNIVERSITY

Miami, Florida

ECONOMIC DEVELOPMENT ON U.S. NATIVE AMERICAN RESERVATIONS:

A CASE STUDY OF THE TRIBES OF FLORIDA

A dissertation submitted in partial fulfillment of

the requirements for the degree of

DOCTOR OF PHILOSOPHY

in

PUBLIC AFFAIRS

by

Diane Benitez

2018 
To: Dean John F. Stack, Jr.

Green School of International and Public Affairs

This dissertation, written by Diane Benitez, and entitled Economic Development on U.S. Native American Reservations: A Case Study of the Tribes of Florida, having been approved in respect to style and intellectual content, is referred to you for judgment.

We have read this dissertation and recommend that it be approved.

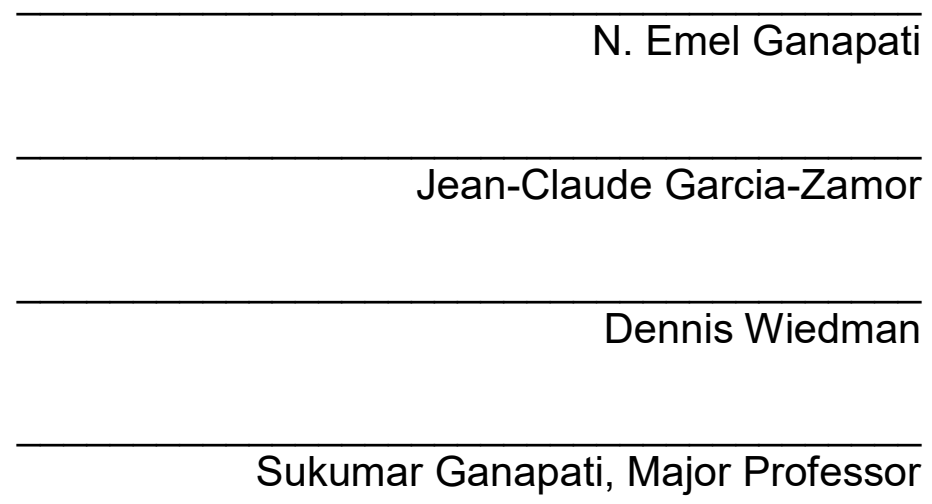

Date of Defense: November 5, 2018

The dissertation of Diane Benitez is approved.

Dean John F. Stack, Jr. Green School of International and Public Affairs

Andrés G. Gil Vice President for Research and Economic Development and Dean of the University Graduate School

Florida International University, 2018 
(c) Copyright 2018 by Diane Benitez

All rights reserved. 


\section{DEDICATION}

I dedicate this dissertation first, to the thoughtful and helpful members and the coworkers of the Miccosukee and Seminole tribes. Their assistance, sensitivity and understanding have made this work possible.

I would be remiss if I fail to thank my family, who helped in so many ways.

Michael and Edward, you mean the world to me. Without your patience and understanding, without your constant love, I would not have been able to accomplish this work. 


\section{ACKNOWLEDGMENTS}

I also want to thank the many people that have helped me along the way. My committee, foremost among them I want to thank my chair and primary confidant, Dr. Sukumar Ganapati, forever pointing me in the right direction as I stumbled through this process and never failing to get me to determine what exactly I am trying to say. Dr. Emel Ganapati, for your guidance through all of this as well as your training in the use of nVivo. Jean-Claude Garcia-Zamor for providing support and believing in me enough to agree to join my committee, the courses you taught on developing nations proved valuable in ways not normally foreseen. Dennis Wiedman, for the introductions and prodding in ways I could not have imagined. Thank you all so much for your patience.

Most importantly, I thank the members of the Seminole and Miccosukee tribes, for sharing with me all your thoughts on my topic and acceding to my incessant appeals for assistance. You have all been so very kind and understanding. Without you this work has no true standing. Thank you all so much for all that you have done for me. My hope is that this dissertation will find its way to assisting U.S. government administrators as well as tribal government administrators in creating the bridges needed to support the required mutually respectful relationship. 


\author{
ABSTRACT OF THE DISSERTATION \\ ECONOMIC DEVELOPMENT ON U.S. NATIVE AMERICAN \\ RESERVATIONS: A CASE STUDY OF THE TRIBES OF FLORIDA
}

by

Diane Benitez

Florida International University, 2018

Miami, Florida

Professor Sukumar Ganapati, Major Professor

Unlike most Native American reservations in the United States, the Seminole and Miccosukee Tribes in Florida are more economically developed. The purpose of this research is to understand this economic development process of these two tribes in Florida. Accordingly, there are three key questions guiding this study:

1. What have been the priorities of the Native American reservation population in conceptualizing sustainable economic development?

2. What external institutional factors have enabled or hindered economic development on Native American reservations?

3. What internal tribal governance factors affected sustainable economic development on Native American reservations?

I interviewed Seminole and Miccosukee tribe members and leaders to obtain insights into answers for the above research questions. I conducted 42 interviews, spanning tribal council members, tribal members residing on and off the reservations, and others working directly with the tribes. 
My main findings are as follows. The Seminoles as well as Miccosukee have placed much emphasis on education. They actively value their sovereignty, taking independent decisions on their development priorities, including education and environment. They have not depended on extensive federal assistance. Moreover, they have successfully managed their gaming operations to the benefit of their members, in supplying education, healthcare, and other services generally undertaken by municipalities. Internally, there are key differences between the Miccosukee and Seminoles. Whereas the Seminoles have sought to integrate with the mainstream economy (for example, they own the Hard Rock Cafe, a large international franchise), the Miccosukee have been focused on their local ecology to sustain their environment. Governance wise, the Seminoles have an elaborate internal governance structure, rivaling any municipality. The Miccosukee have is smaller, indigenous structure of direct democracy.

From a policy perspective, the main recommendation is that the Native American tribes be allowed to exercise their sovereignty to fulfill their own economic development goals. External federal and state government relationships should be based on mutual respect and reciprocity in relationships. Distrust could be inimical to the tribes' economic progress. Support should be provided to the tribes to develop their own governance structures appropriate to their economic development priorities. 


\section{TABLE OF CONTENTS}

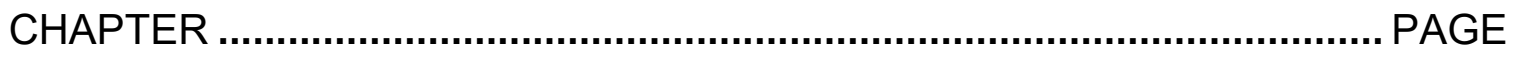

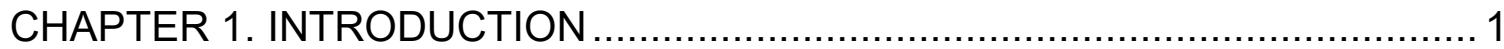

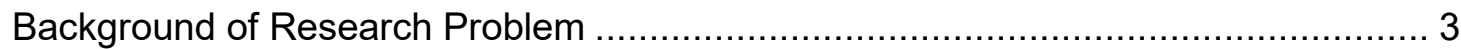

Economic Development of Native American Reservations..................................... 6

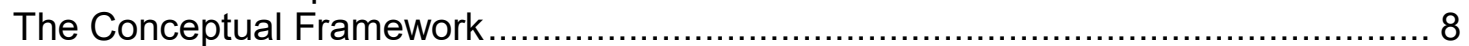

Theoretical Perspective …...........................................................................

Economic Development in Seminole and Miccosukee Reservations........................11

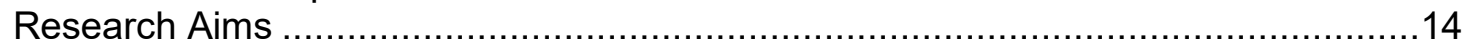

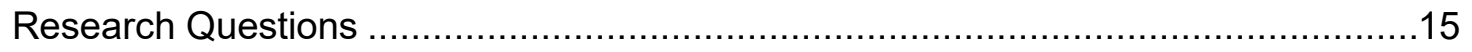

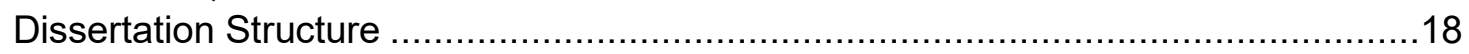

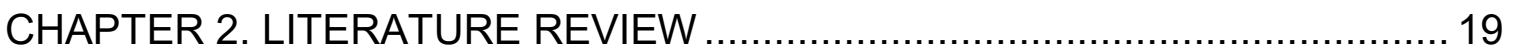

Sustainable Economic Development Theory ..............................................19

Community or Rural Economic Development...................................................21

Native American Economic Development ………………………………......22

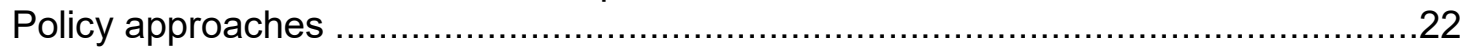

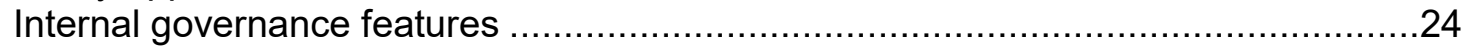

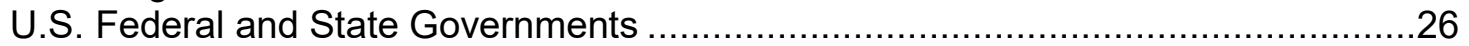

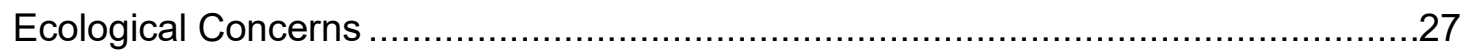

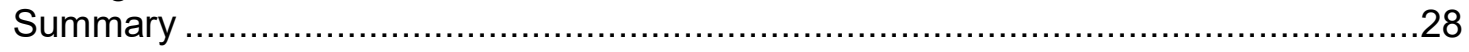

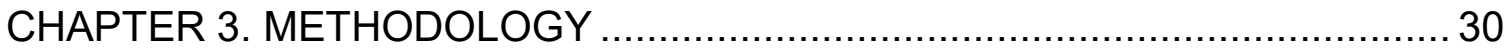

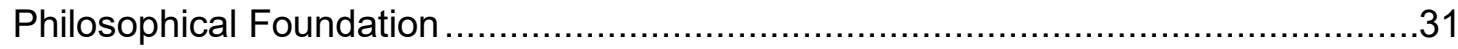

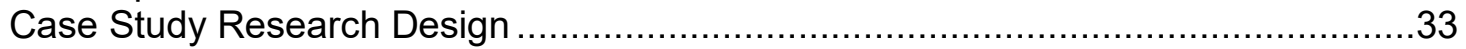

Institutional Review Board Process ...............................................................

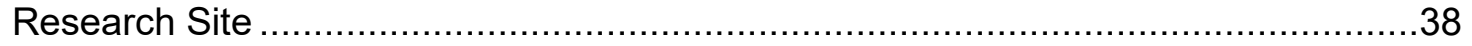

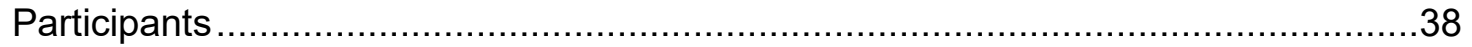

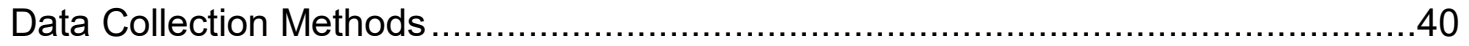

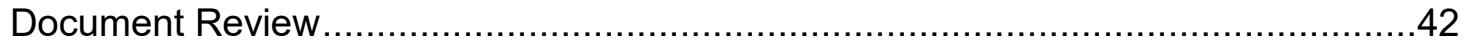

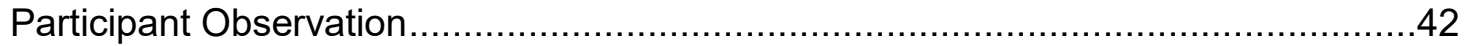

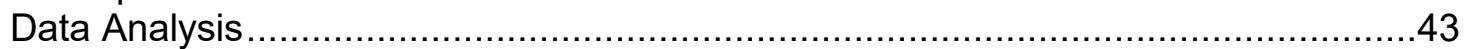

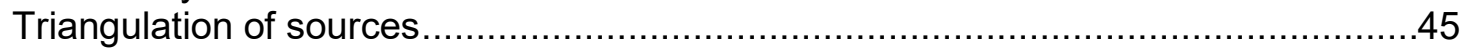

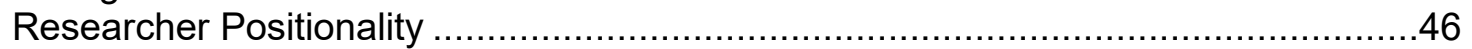

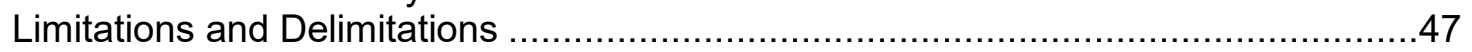

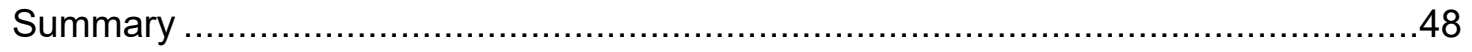

CHAPTER 4. HISTORY OF THE SEMINOLE AND MICCOSUKEE TRIBES .... 50

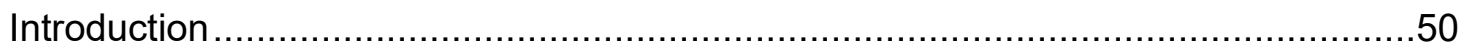

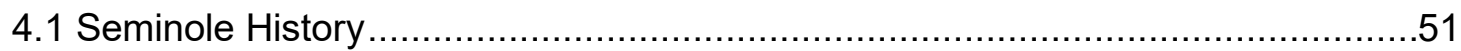

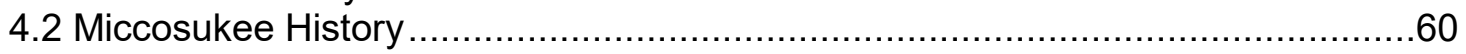

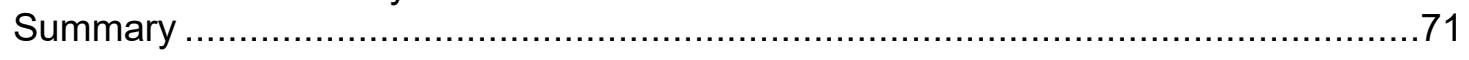

CHAPTER 5. SUSTAINABLE ECONOMIC DEVELOPMENT PRIORITIES .......73

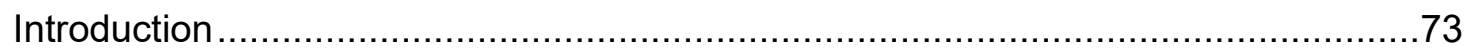

5.1 Economic Development Priorities of the Seminole Tribe ..................................75

Cultural and Historical Sharing ......................................................................

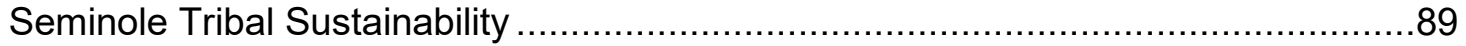

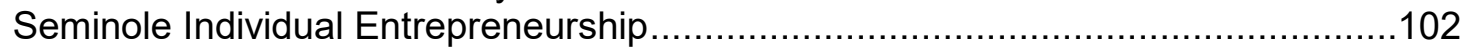


5.2 Economic Development Priorities of the Miccosukee Tribe of Indians of Florida

Cultural and Historical Sharing.....

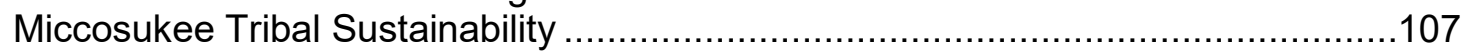

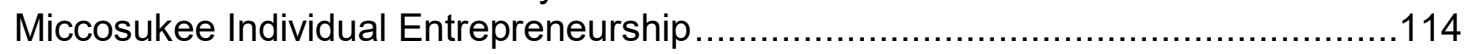

5.3 Shared Economic Priorities and Concerns ...................................................115

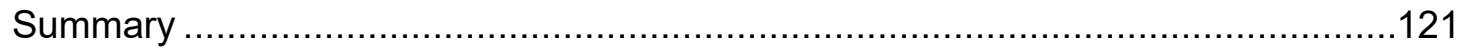

CHAPTER 6: INTER-GOVERNMENTAL FACTORS ….............................. 124

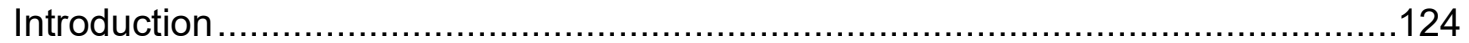

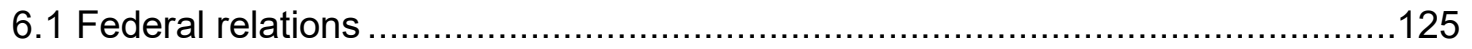

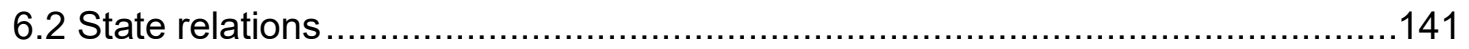

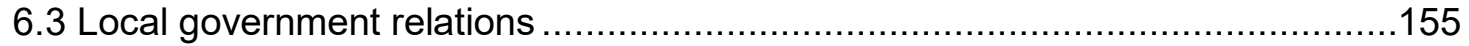

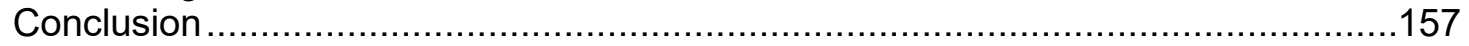

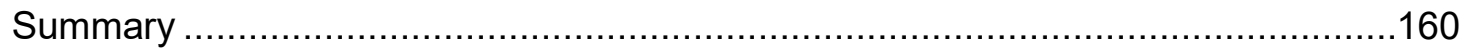

CHAPTER 7: TRIBAL GOVERNMENTAL FACTORS .................................. 163

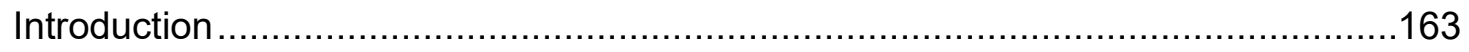

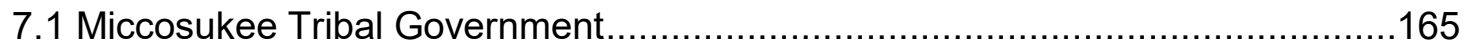

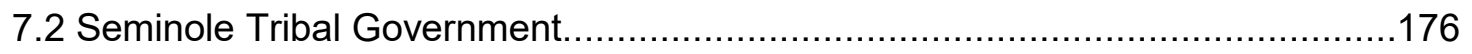

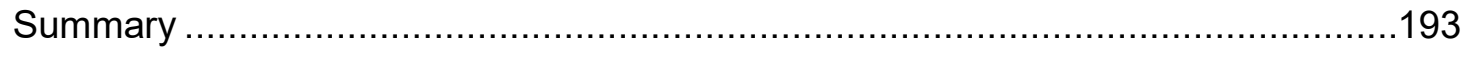

CHAPTER 8: CONCLUSION AND RECOMMENDATIONS ........................... 197

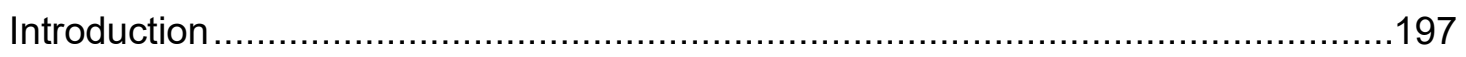

8.1 Theme 1: Native Americans should be able to determine their own economic development priorities..........................................................................20

8.2 Theme 2: External agencies should be empathetic to Native American

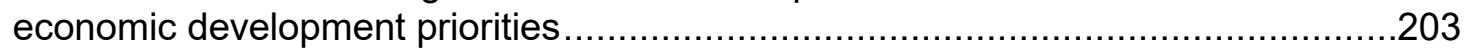

8.3 Theme 3: Support tribes to develop their own governance structures appropriate to their economic development priorities …….................................205

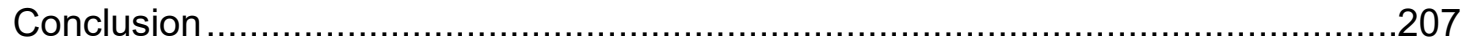

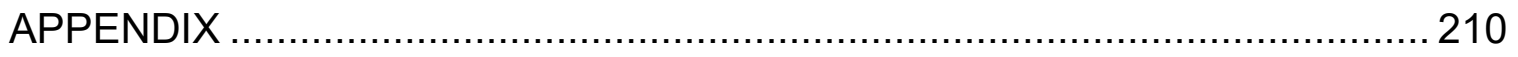

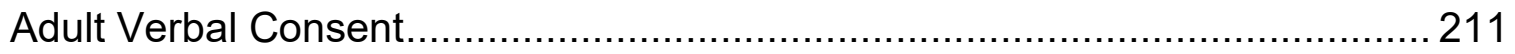

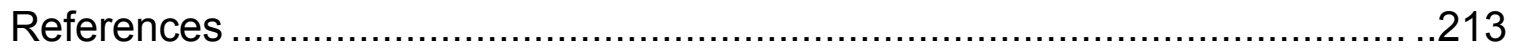

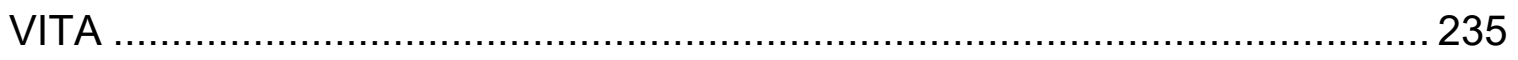




\section{LIST OF TABLES}

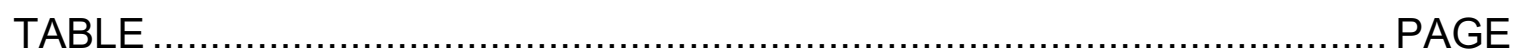

Table 3.1 Age Distribution of Interviewees ....................................... 39

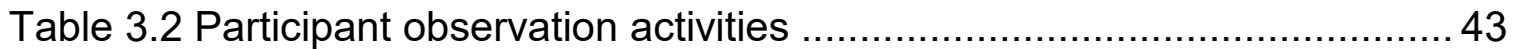

Table 6.1 Table of 2014 Casino contributions to states............................ 148 


\section{LIST OF FIGURES}

FIGURE PAGE

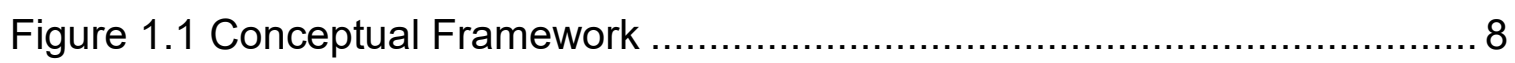

Figure 2.1 Seven Dimensions of Triple Bottom Line..................................... 20

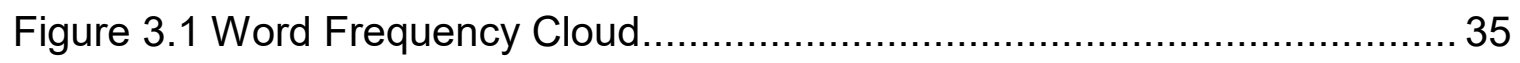

Figure 4.1-4.2 Event flyer and picture of original Miccosukee......................... 54

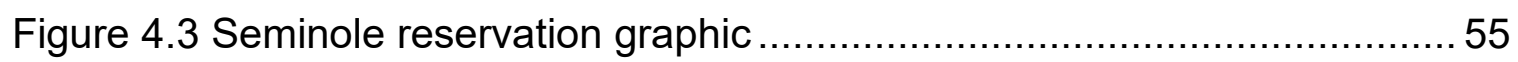

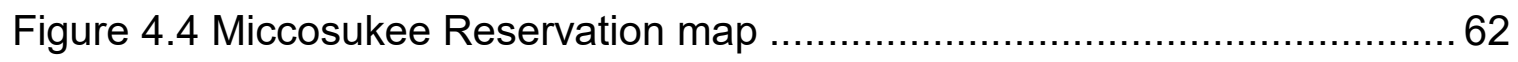

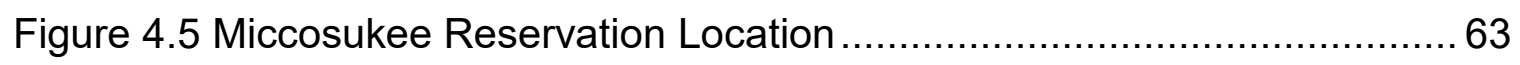

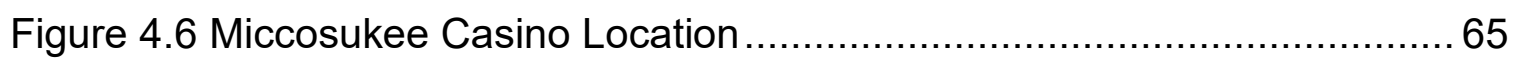

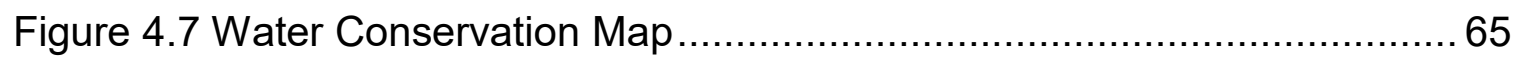

Figure 4.8 Photo of Tribal Government Flags at Standing Rock ...................... 70

Figures 5.1-5.3 Seminole Pow-wow activities and flyer, 2018 ….................... 78

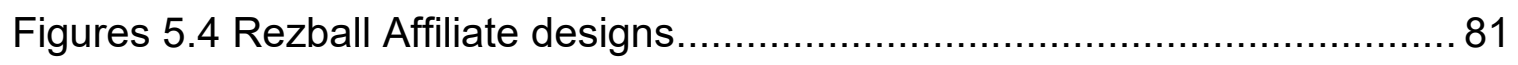

Figures 5.5-5.7 Seminole Recreation Facility in Hollywood ............................. 82

Figures 5.8-5.10 Graphics provided by the Ah-Tah-Thi-Ki Museum for the

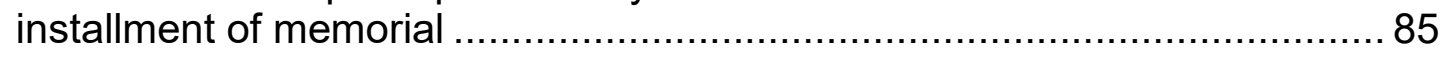

Figures 5.11-5.12 Photos taken at the Red Barn at the Brighton Reservation .. 87

Figure 5.13 Photo provided by Ah-Tah-Thi-Ki Museum.................................. 88

Figure 5.14 Photo taken at Ah-Tah-Thi-Ki Museum anniversary celebration ..... 89

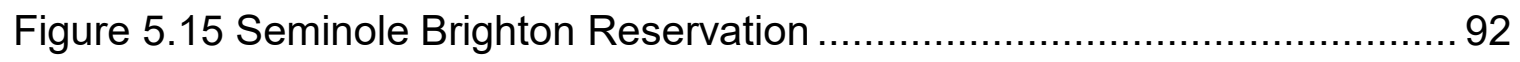

Figure 5.16 Photo of Seminole Brand Water ................................................ 94 
Figures 5.17-5.20 Construction of Hard Rock Hollywood 98

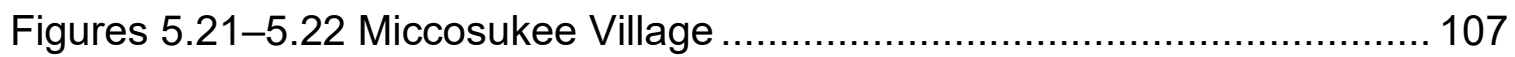

Figure 5.23 - 5.24 Overviews of the Miccosukee Golf Course ......................... 109

Figures 5.25-5.29 Aerial photos of land identified as Miccosukee owned........112

Figures 5.30-5.33 Photos of farmers markets supported by Miccosukee tribe.

Figures 5.34-5.37 GIG lunch for walkers at FIU …................................. 119

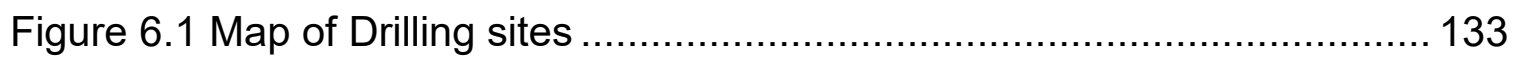

Figure 7.1 Depiction of Miccosukee Government Structure .......................... 165

Figure 7.2 Photo of Buffalo Tiger and Don Osceola .................................... 168

Figure 7.3. FFWL personnel training volunteers and signage at school event......

Figure 7.4 Everglades Water Sample Map .............................................. 174

Figure 7.5 Photo of Volunteering with Love the Everglades cleanup............... 176

Figure 7.6 Graphic Depiction of Seminole Government Structure ................... 177

Figure 7.7 Aerial View of Seminole Aviation Strip........................................ 182

Figure 7.8 Aerial view of Seminole Water plant ........................................ 189

Figure 7.9 Aerial View of Seminole Veterans Building ................................... 191

Figures 7.10-7.12 Iwo Jima Memorial ....................................................... 192

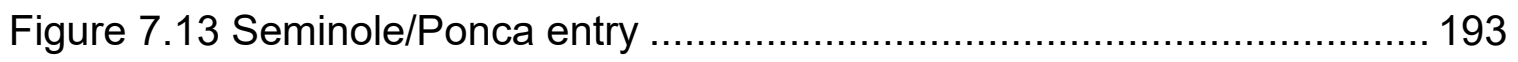

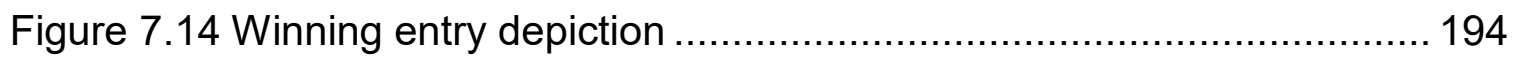




\section{ABBREVIATIONS AND ACRONYMS}

ED (Economic Development): Refers to sustainable economic development, both mainstream and upon Native American reservations.

CED (Community Economic Development): Refers to the inclusion of the community in deciding the most effective path for economic development.

BIA (Bureau of Indian Affairs): Refers to the Federal agency which interacts with Native American Tribal Entities for the Federal government.

TEK (Traditional Ecological Knowledge): Refers to knowledge known through traditional teachings within the Native American population. Science has begun to understand teachings which Native American populations have passed down through traditional generational teaching.

TBL (Triple Bottom Line Concept): Refers to economic, environmental and social value of investment that may increase outside organizations' financial bottom line.

NGO (Non-Governmental Organization): Refers to a non-profit, voluntary group organized on a local, national, or international level.

DED (Department of Economic Development): Refers to a department within the Department of Interior that provides economic development policy when dealing with Native American economic development.

IGRA (Indian Gaming Regulatory Act): Refers to a 1988 US federal law that set up the jurisdictional framework which governs Indian gaming.

CDFI (Community Development Financial Institution): Refers to institutions created as part of the Department of Treasury under the Riegle Community Development and Regulatory Improvement Act of 1994.

SFWMD (South Florida Water Management District): Refers to the regional governmental agency that oversees water resources from Orlando Florida to the Florida Keys.

ISDEAA (Indian Self Determination and Education Assistance Act): Refers to the legislation that affords authority in decision making to the tribes. 


\section{CHAPTER 1. INTRODUCTION}

This dissertation is an examination of economic development of Native Americans. The Native American reservations have been ignored by the formal economic development processes for decades. The lack of economic development has resulted in Third-world like conditions in the reservations. As President Obama stated in 2014, Native Americans have a much higher poverty rate than the national average, and their school dropout rates are twice the national rate. He contended that these high rates are a "moral call to action". Despite the dire economic conditions of the reservations, the scholarship on economic development of the Native American reservations is very limited. The dissertation study aims to fill this wide gap on sustainable economic development in Native American reservations. Sustainability is a key aspect, since most of the reservations are on ecologically sensitive lands, where the tribes have a close relationship with nature. It further fills the gap in literature on Native American governance.

The empirical focus of this dissertation is on the reservations of the two Florida tribes of Seminole and Miccosukee. The formal names for the two tribes are the Seminole Tribe of Florida and the Miccosukee Tribe of Indians of Florida. The former is referred to as Seminole and the latter is referred to as Miccosukee in this dissertation. These two tribes have been quite entrepreneurial, unlike most other Native American tribes. They have advanced economically on several indicators. The Hard Rock Café, one of the most successful American franchises, with a prestigious global presence, is owned by the Seminoles. At the same time, 
the tribes face challenges similar to other Native American reservations in terms of social and physical infrastructure. Studying these two tribes has been useful for obtaining insights into the factors that enable (or constrain) the economic development activities of the Indian tribes. The two Florida tribes have received very little attention in the scholarly literature. The limited literature on Native American economic development has largely focused on other tribes like the Apaches, Cherokees, Navajos, and so on. However, the reservations of the two Florida tribes also require examination, especially because of their relative entrepreneurial success.

The overall purpose of this dissertation is to identify the factors influencing the entrepreneurial successes and challenges facing the two Florida tribal reservations. Towards this end, the study has three aims. The first is to identify the tribes' sustainable economic development priorities. The strategies of economic development vary by the community's context, depending on these priorities. The second aim is to identify the external institutional forces that enable or hinder the reservations' economic development. Native American reservations are considered sovereign nations, which have government to government relationships with federal, state, and local governments. The nature of these relationships shapes the economic development in the Native American reservations. The third aim is to identify the internal features of tribal governance that have impacted the economic development process. As sovereign nations, the internal features of the Native American reservations are crucial to their ability to pursue their own economic development priorities successfully. 


\section{Background of Research Problem}

In the United States, there are 566 federally recognized tribes living on 334 reservations which are state or federally recognized. The reservations, which are legally defined geographic areas under federal and tribal jurisdictions, comprise of about 56.6 million acres of land in the continental United States (Wood, 1994). According to the 2010 U.S Census, the tribal population (people who identify themselves as American Indian and Alaska Native, either alone or in combination with one or more races) was over 5.2 million in the United States (Norris, Vines, \& Hoeffel, 2012). The tribes form a small minority (about 1.7\%) of the country's population, but constitute a significant group often left out of the mainstream economic development processes.

The economic indicators of the Native Americans are generally below that of other minority groups in the United States. Although a few reservations have access to funds through oil drilling, and some reservations have gaming operations, Native Americans are generally poor and face economic development challenges (Miller, 2012). There are innumerable examples of the disparities between the living conditions of the Native American reservation population and the average U.S. population. As per Sarche and Spicer (2008, p. 126), "More than one-quarter of the American Indian and Alaska Native population is living in poverty, a rate that is more than double that of the general population and one that is even greater for certain tribal groups." According to 1990 census data, unemployment rates range from $14.4 \%$ to as high as $35.3 \%$ within some reservations (Sanderfur \& Liebler, 1997, p. 98). 
Per capita income of the Native Americans living on the reservations is less than half the U.S. average, consistently falling far below that of Hispanics, African Americans, and Asian Americans (Akee \& Taylor, 2014). Between 2007 and 2011, poverty rates among the American Indian and Alaska Natives were above 27 percent, compared to $16.2-26.3 \%$ for Hispanics, and $25.8 \%$ for Blacks (Macartney, Bishaw, \& Fontenot, 2013). The 2013-14 school year graduation rate for the American Indian and Alaska Natives was about $69.6 \%$ compared to $76.3 \%$ for Hispanics and $72.5 \%$ for Blacks (National Center of Education Statistics, 2015). Unemployment levels in the reservations have historically ranged between 20 and 80 percent (Miller, 2012). The White House's 2014 Native Youth Report concluded that the Native American youth's social, education, health, and other barriers are "nothing short of a national crisis" ( $p$. 38).

The economic plight of the Native Americans in the reservations has received very little scholarly attention. Indeed, Native American tribal governance is "missing" from public administration literature, as observed by Aufrecht (1999) and echoed by Ortiz (2002). Very little has changed since then-even Ronquillo's (2011) critical review of Aufrecht shows disparate "unassembled" coverage of Native Americans' governance. The literature on economic development of the Florida reservations is even thinner. Studies by the prestigious Harvard Project on American Indian Economic Development have focused on several Native American tribes over the last two decades. However, the Harvard project has not conducted substantial studies of the two Florida tribes of Seminole and 
Miccosukee. One exception is Cattelino's (2008) study, which focused on the nexus between gaming and identity among Seminoles. The dissertation gains significance in this context, aspiring as it does to fill an all too obvious gap in the literature on economic development in Native American reservations in Florida.

In the context of the lack of economic development in Native American reservations, the two Florida tribes are particularly intriguing, since they have undertaken successful entrepreneurial activities. The Seminole population is about 3,680 on about 90,000 acres of trust land, a prime part of which is urban. The Miccosukee population is about 589 , spread over 74,872 acres of trust land, though much of the land (about 54,812 acres) is under water. The Seminoles have successfully developed their gaming enterprises, which has been emulated by several other Indian tribes. Notably, they bought the Hard Rock Hotel and Casino chain for nearly a billion dollars in 2006 (Hansen \& Skopek, 2011). They have developed successful tourist attractions such as the Ah-Tah-Thi-Ki Museum and Billie Swamp Safari. They operate their own school, and members have modern housing and access to health care. The Miccosukee tribe has similarly maintained a successful tourism and entertainment industry, including casino and wetlands tourism (Wiedman, 2010). At the same time, the Seminole and Miccosukee tribes have faced economic development challenges of education, housing, physical infrastructure, etc., similar to other Native American tribes. In this context, an examination of the factors that enabled the Seminole and Miccosukee tribes to be entrepreneurially successful becomes particularly relevant. 


\section{Economic Development of Native American Reservations}

The economic development of Native American reservations can be partly traced to the governance structures resulting from the Native Americans' historically strained relationships with the federal government. Since 1934, the relationship between the U.S. federal and Native American tribal governments has been paternalistic, with the former often intent on the assimilation of Native American citizens into mainstream society through destruction of Native American culture and expropriation of their landed property (Miller, 2012). The Indian Restoration Act of 1934 sought to restore the landed property and rehabilitate tribal governance and economic activities. However, the termination policy (Public Law 280 passed in 1953, in effect until 1968) imposed state level criminal and civil jurisdiction on the reservations, terminated federal recognition and aid to over 100 tribes, and emphasized physical relocation from reservations to urban areas. Over two million acres of trust land was no longer protected, resulting in sale of the land to non-Native Americans.

The termination policy became an embarrassment during the civil rights movement in the 1960s, which ultimately prompted a change in policy direction toward self-determination and self-governance. The Indian Self Determination and Education Assistance Act (ISDEAA) of 1975 (and amendments since then) increased tribal participation in the management of Federal Indian programs (Williams, 2011). The ISDEAA gave Native Americans the first opportunity to provide input into programs affecting their lives. Native Americans could now take control of their children's education by operating their own schools, which 
allowed them to resurrect their language, culture, and traditions. Since then, federal agencies affecting Native Americans, such as the Bureau of Indian Affairs and the Indian Health Services, have increasingly entered into self-determination and self-governance compacts and contracts with the different tribes. Federal laws have also provided space for greater control to Native Americans over the reservations. The 2012 Helping Expedite and Advance Responsible Tribal Homeownership (HEARTH) Act enabled tribes to control their lands by allowing them to develop and implement their own laws governing the leasing of reservation lands for residential, business, renewable energy, and other purposes without federal approval.

As sovereign nations, the federally recognized tribes on the reservations have government to government relationships with the federal and the state governments. The federal government has a fiduciary trust responsibility ("moral obligation of the highest responsibility and trust," as per the Supreme Court ruling in Seminole Nation v. United States, 1942). The trust relationship entails the protection of property on the reservations and the promotion of self-governance. State governments do not have regulatory authority over the reservations; the states typically do not have civil or criminal jurisdiction over the reservations (except when allowed under Public Law 280) (Aufrecht \& Case, 2005). The tribes thus have the prerogative of self-governance, with their own government structures, laws (civil and criminal), and regulations (e.g., licenses, taxation, zoning, etc.) (Ortiz, 2002). Recognized tribes have their own constitutions and 
distinctive legislative bodies (often in the form of tribal councils) and law enforcement agencies.

\section{The Conceptual Framework}

The conceptual framework for the dissertation draws on the above two dimensions of how external institutional forces and internal governance processes have influenced the economic development of the Native American reservations. The conceptual framework is graphically represented in Figure 1.1.

Figure 1.1 Conceptual Framework
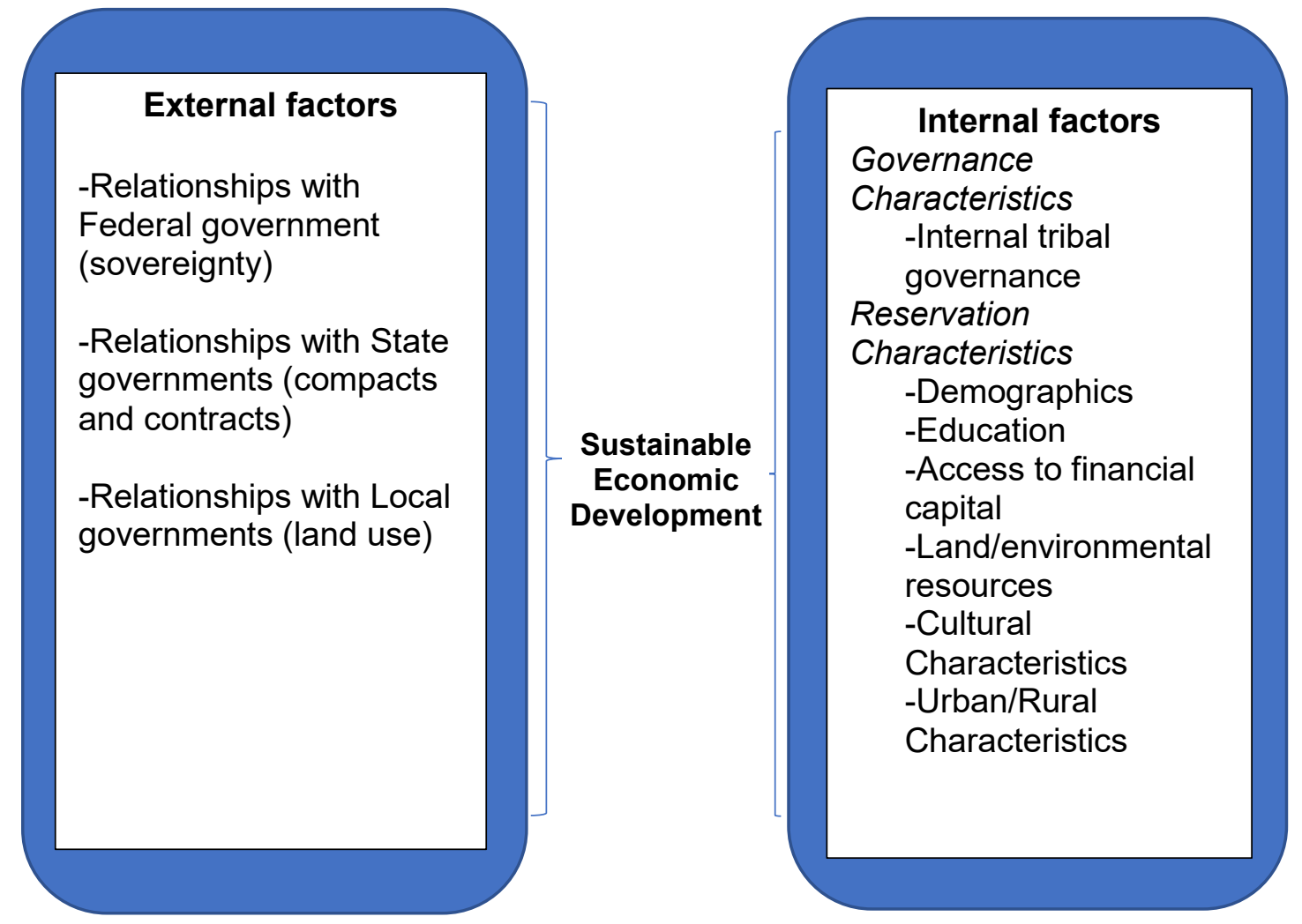

At the external institutional level, as the abovementioned historical evolution of the Native Americans shows, the reservations are sovereign nations, 
and have government to government relationships with the federal as well as other governments. The institutional relationships with the federal, state, and local governments influence the economic conditions of the reservations (Zaferatos, 1998; Ragsdale, 1991; Wagner, 2008). The federal government has a direct fiduciary responsibility for the reservations through the Bureau of Indian Affairs (which is located within the Department of the Interior). The state governments do not have such direct relationships, since the states have no regulatory authority. However, the reservations may have agreements such as compacts and contractual arrangements with the state governments to pursue economic activities (such as gaming). The relationships with the neighboring local governments matter for the reservations due to the geographical spillovers. Local land use of the neighboring communities, for example, influences the economic activities of the reservations.

Concomitant with the external relationships, the internal features of the Native Americans in the reservations form another set of factors influencing their economic development. Indeed, the sparse literature that exists on Native Americans' economic development emphasizes the significance of selfdetermination and self-governance in the reservations' economic growth (Miller, 2012; Van Otten \& Vasquez, 1992). Cornell and Kalt (1992; 2007) privilege nation building from within the tribal reservations as the preferred strategy. The tribes must exercise their sovereign decision-making power and leadership in shaping their priorities of development; they must also have effective institutions of self-governance for implementing strategic development. Tribal control over 
natural resources (e.g., oil, land, etc.) provides opportunities for economic development (LeBeau, 2001). Vinje (1996) notes that gambling has become a prominent strategy of economic development, at the expense of promoting public/ private employment, use of natural resources, and manufacturing. $\mathrm{He}$ argued for privileging education as a means of uplifting the economic conditions in the reservations. Mika (1995) claimed that private non-Indian investments in the reservations are attractive for economic development but could have the unintended consequence of assimilating the Native American population into mainstream American society. Some lawyers and economists go a step further to advocate instituting market mechanisms on the reservations (e.g., individual property rights as opposed to communal property rights) for effective development (Anderson \& Benson, 2006; Rosser, 2005).

\section{Theoretical Perspective}

This dissertation is guided by the grounded theory approach. Pragmatism and symbolic interactionism (Corbin \& Strauss, 1990) form the basic principles of grounded theory. There are two important principles, drawn from the traditions which build this method. The first is change, because phenomena are in a state of constant flux, reacting to interacting conditions. The second is nondeterminism, the rejection of strict "determinism". There are always choices to make, even the refusal to make a choice is in effect a choice. Grounded theory looks not only to reveal conditions but also to understand how stakeholders respond to those conditions and the consequences of their actions. Grounded 
theory is a general theoretical framework which reveals emerging patterns within collected data (Scott, 2009).

\section{Economic Development in Seminole and Miccosukee Reservations}

The Seminole and Miccosukee people have both been groundbreaking in undertaking entrepreneurial activities for economic development. The overt entrepreneurialism is especially exhibited in their leading role in the gaming industry, which has since been emulated by several other Native American tribes nationally. They have fiercely guarded the casino and related operations, both through litigation and cooperation with the state government. The Seminole tribe was the first to utilize litigation to ensure sovereignty, solidifying their ability to utilize casinos to generate economic development. The Seminoles established the first Bingo hall in 1979. The establishment was challenged in a legal suit filed by Bob Butterworth, a Broward Sheriff and later Florida State Attorney (Seminole Tribe of Florida v. Butterworth), who argued that Bingo operations violated state gambling laws. The state of Florida lost in federal appellate court on the grounds that the Seminole tribal sovereignty protected gaming from state taxation and regulation (Cattelino, 2008, p. 344). This decision resulted in an opportunity for all tribal governments to seriously look at establishing casinos for additional income. Subsequent increase in the tribes adopting gaming operations, consequent tensions with state governments, and federal interest in gaming resulted in the federal government passing the Indian Gaming Regulatory Act (IGRA) in 1988. The IGRA established a separate National Indian Gaming Commission (NIGC) to regulate the gaming activities. Indeed, gaming became 
one of the significant means for Native Americans to improve their economic condition over time. The gross gaming revenues increased from $\$ 100$ million to over $\$ 28$ billion, as the number of tribal gaming operations increased from 30 to 450 between 1988 and 2013 (Akee, Spilde, \& Taylor, 2015). The IGRA identified three tiers of gaming: Class I (low stakes, regulated entirely by the tribe), Class II (games of chance such as bingo, overseen by NIGC), and Class III (high stakes card and other casino games, regulated by NIGC and in agreement with state governments). The IGRA required the state governments to negotiate with tribes in good faith with respect to the Class III games and enter into compacts.

The Seminole Hard Rock Hotel and Casino and the Miccosukee Resort and Gaming flourished over the years (Cattelino, 2008). The state government received funds from tribal compacts. The Seminole tribe had promised to spend over a billion dollars to upgrade the Hard Rock Casinos in Hollywood and Tampa, build two new hotels and add another 4,000 permanent jobs to the tribal payroll if their renegotiated compact of a new long-term deal with the state was approved. The Seminoles' negotiation over the compact, as the old compact expired in July 2015, was tenacious, lasting well into 2018. Controversies stemming from competition with other private gaming operators in the state had stalled negotiations. Although the state governor entered into a compact with the tribe in December 2015, the compact failed ratification by the state legislature. The Seminoles have sued the state government under the IGRA, requiring the state to negotiate in good faith. 
Just as the Seminole tribe was a pioneer in opening casinos as a means of economic development, the Miccosukee tribe led the way regarding implementing federal contracts. In 1970, the Miccosukee tribe determined that they should operate and control their own school program and all other social services provided by the Bureau of Indian Affairs (BIA). Despite the resistance to disbursing funds directly to the tribes, with the support of the then Senator Lawton Chiles of Florida, the Miccosukee tribe became the first American Indian tribe to implement direct contracting with the federal government (Tiger \& Kersey Jr., 2002, p. 149).

Although gaming has been one of the manifest economic growth engines for the Native American reservations, the National Gambling Impact Study Commission (1999) highlighted the loss of culture as a common concern accompanying the growth of tribal gaming. Cattelino (2008), however, argues that the intersection of the rise in income from gaming and the loss of culture is quite complex, and is not related to the increase in wealth alone. She claims that the "casino-based bureaucratization of cultural production has shifted both the politics and the locus of culture in the Seminole Country" (Cattelino, 2008, p. 66).

In addition, the overt attention to tribal gaming has overlooked the indigenous economic development priorities of the Native Americans. Indeed, although the tribes have taken remarkable economic strides with the gaming revenues, the gains mask the weak economic conditions of the tribes. The per capita income of Native Americans is still less than half the national average; education levels are lower, and poverty is three to four times the national 
average; labor force participation is much less than the national average. Tribal schools face high dropout rates. The reservations also face housing challenges (overcrowding and lack of plumbing) and infrastructure deficiencies (roads and sewage disposal) (Akee, Spilde, \& Taylor, 2015, p. 187, Table 1). Cattelino (2008) also notes the failures in casino wealth distribution, although the casinos have helped fund many schools and social activities. The indigenous economic priorities of the Seminoles and Miccosukee tribes thus need further investigation, in order to comprehend the overall economic development process of the tribal reservations.

\section{Research Aims}

Seminole and Miccosukee tribes have carried out successful entrepreneurial activities on their reservations, but they also face economic development challenges at the same time. The overall purpose of this dissertation is to identify the factors influencing the entrepreneurial successes as well as the economic challenges facing the two Florida tribal reservations. Towards this end, the study has three aims. The first aim is to identify the tribes' sustainable economic development priorities. Identifying these priorities is important to understand the tribes' educational, cultural, and social goals. While the casino revenues have improved the tribes' economic conditions, identifying the priorities provides insights into the alignment between the development outcomes and the tribes' preferences.

The second aim is to identify the external institutional forces that enable or hinder the reservations' economic development. The Native American 
reservations are considered sovereign nations, which have government to government relationships with federal, state, and local governments. The nature of these relationships shapes economic development in the reservations. The Seminoles and Miccosukee have had both collaborative and conflicting relationships, through compacts and litigation over the rights to conduct economic activities like the casinos. Moreover, since many of the reservations are close to the Everglades, the relationships also affect the natural resources which many of the activities depend upon.

The third aim is to identify the internal features of tribal governance that have impacted the economic development process. As sovereign nations, the internal features of the Native American reservations are crucial to their ability to pursue economic development strategies successfully. The governance structures of the Seminoles and Miccosukees are slightly different-whereas the Seminoles have separate councils for governance and business development, the Miccosukees have a single council that overlooks both. The governance structures could also influence how the tribes distribute their resources, such as those generated through the casino revenues.

\section{Research Questions}

Consistent with the above research aims, there are three exploratory research questions guiding this dissertation. The questions and the methods are set out below. 
Question 1: What have been the priorities of the Native American population in conceptualizing sustainable economic development in the Florida reservations?

Drawing from the prior discussion, the guiding hypothesis is that the Seminoles and Miccosukees have distinct priorities of economic development, which may include but are not limited to gaming, environment, and tourism. I explore the extent to which the tribes value education, employment, and private business development. Identifying the priorities helps in understanding the extent to which the present strategies meet the tribes' goals in Florida.

To explore this question, I conducted secondary document analysis of publications archived at the Ah-Tah-Thi-Ki Museum, which is a facility sponsored by the Seminole tribe to preserve their records. I also reviewed relevant newspapers such as the Seminole Tribune (a paper published by the tribe) and the Miami Herald (a regional newspaper, often covering events and news about the reservations). I was a participant observer in many of the events and activities conducted by the Seminole and Miccosukee tribes. Lastly, I conducted in-depth interviews with key tribal members of the Seminole and Miccosukee tribes.

Question 2: What external institutional factors have enabled or hindered economic development in the Florida reservations?

The guiding hypothesis is that the intergovernmental relationships with external governments (federal, state, and local) have influenced economic development. Federal policies circumscribe the fiduciary trust relationships as the 
tribes are sovereign nations; collaborative (or conflicting) relationships with state governments (e.g., through compacts) impact the tribes' economic activities; and local government relationships are significant for the local activities.

To answer this question, I reviewed the policy documents at the federal, state, and local governments that pertain to economic development aspects in the reservations. The documents reveal the nuances of the policies and intergovernmental relationships that have influenced the economic activities on the reservations.

Question 3. What internal tribal governance factors have affected the sustainable economic development of the Native American reservations in Florida?

From the foregoing discussion, the guiding hypothesis is that the institutions of self-governance are critical for sustainable economic development. The Seminoles and Miccosukees have distinctive governance features, guided by their constitutions. Their reservations are also distinctive, with a close relationship to the Everglades.

To explore the question, I analyzed the constitutions of the Seminole and the Miccosukee tribes for the distinctive elements of the formal governance structures. I examined newspaper articles (e.g., in the Seminole Tribune and other local publications) as to how the tribal governance structures have impacted economic development projects. I interviewed elected and other community leaders about how they have shaped their major programs (beyond the casinos). The interviews provided insights into how the formal and informal 
governance structures have influenced the tribes' economic development activities (e.g., gaming, tourism, infrastructure development, education) in the reservations. I observed the open tribal community meetings as well as local government public meetings pertaining to the tribes.

\section{Dissertation Structure}

This chapter provided an introduction to the dissertation study, with an overview of the background of Native Americans' economic development. Although Native American reservations in general lack economic development, the Seminoles and Miccosukee have been successful entrepreneurially. Hence, this dissertation is an examination of their development priorities and the external and internal factors that have influenced such priorities. Chapter 2 reviews the literature on economic development, focusing on Native American reservations and the challenges faced within these locations. Chapter 3 outlines the research methods. Chapter 4 discusses the background of the Seminole and Miccosukee tribes. Chapter 5 provides the perspectives of the Miccosukee and Seminole tribes of Florida on sustainable economic development priorities. Chapter 6 gives an insight into the external institutional factors affecting their sustainable economic development. Chapter 7 offers insights into the internal tribal governmental factors affecting sustainable economic development. Chapter 8 concludes the study with policy recommendations for Native American reservations. 


\section{CHAPTER 2. LITERATURE REVIEW}

There is a dearth of scholarly literature in the public administration discipline about Native American populations. Most research concerning Native American populations, especially on the reservations, concentrates on medical and health issues (Allison, Rivers, \& Fottler, 2007; Koithan \& Farrell, 2010). Healthcare includes the difficulties resulting from unemployment, poverty, and cultural oppression, as also traditional Indigenous medicines and the benefits thereof. Advancements in economic development have improved medical and health issues, though this calls for continued efforts. Although the Native American reservations have traditionally lagged behind in economic development, they have not received much attention from public administration scholars. Consequently, this chapter reviews the general economic development approaches and their suitability in the context of Native American reservations.

\section{Sustainable Economic Development Theory}

The UN General Assembly suggests that sustainable economic development should occur in ways that meet the needs of current generations while ensuring conditions and opportunities for future generations to do the same thing (World Commission on Environment and Development, 1987). The Global Reporting Initiative (GRI) of 2001 facilitated the communication of economic development impacts on issues of climate change, human rights, and corruption by businesses, governments, and other organizations. John Elkington advanced the triple bottom line (TBL) concept as the economic, environmental, and social value of investment (add or destroy) outside a corporate financial statement 
(Elkington, 1999). He pointed to a global cultural revolution where businesses will drive development decisions, rather than governments or NGOs. He identified seven aspects of sustainable economic development (Figure 2.1). He argued that markets will become more competitive, both at the domestic and international levels. Values will be a key driver in consumer choices. For example, major oil companies cannot keep out of controversial value laden issues like human rights violations or mistreatment. Such violations cannot be kept out of the news cycles and out of consumers' minds through secretive large court settlements. Due to the collapse of traditional authority and the melding of value systems as international trade evolves, stakeholders will demand much information about the businesses for benchmarking and comparisons.

Figure 2.1 Seven Dimensions of Triple Bottom Line

\begin{tabular}{|l|l|l|}
\hline & Old Paradigm & New Paradigm \\
\hline Markets & Compliance & Competition \\
\hline Values & Hard & Soft \\
\hline Transparency & Closed & Open \\
\hline Life-cycle technology & Product & Function \\
\hline Partnerships & Subversion & Symbiosis \\
\hline Time & Wider & Longer \\
\hline Corporate Governance & Exclusive & Inclusive \\
\hline
\end{tabular}

Source: Elkington "Enter the Triple Bottom Line"

The forming of partnerships, where "sworn enemies" find ways to work together, were posited as the "keys to success" in Elkington's framework. Rather 
than keeping up with ever-changing events, Elkington suggested that the importance of 'just in time' preparation will give way to the longer run development outcomes. Finally, corporate governance changes will loom large as concerns rise about the proper balance between shareholders and stakeholders. Elkington suggested that a key driver of these changes in basic assumptions stem from the unsustainability of the current patterns of wealth creation and distribution, placing pressure on both corporations and governments to transition. TBL concepts posit an inevitable pattern shift from an old to a new paradigm of economic development. TBL's theories and prescriptions for global economic development resonate with Native American reservation economic development.

\section{Community or Rural Economic Development}

Community and rural economic development policies can be relevant to some of the reservations' economic development issues. Rural Black and Latino communities have suffered persistent poverty resulting due to isolation of such communities from economic development opportunities. The Native Americans have also long suffered from such economic isolation, where they have been denied development opportunities due to various constraints. Community Economic Development (CED) principles focusing on underdeveloped, primarily minority neighborhoods, call for equitable development. CED advances economic self-sufficiency and property ownership as the means to economic development while also maintaining the struggle for civil rights and social equity as espoused by Booker T. Washington (Cummings, 2001, p. 410). These 
concepts may be vital in addressing Native American reservations that are far away from urban areas and where gaming may not be feasible.

\section{Native American Economic Development}

\section{Policy approaches}

The existing research about economic development of Native American tribes has happened primarily in the western and northeastern reservations. The western Navajo, Lakota and Dakota Sioux, Apache, and Inupiaq (Inuit) are subjects of much research (Hosmer \& O’Neill, 2004; Ruffing, 1976; Benson, Lies, Okunade, \& Wunnava, 2009). Northeastern Cherokee, Mohawk, Iroquois, Oneida, or Mohican reservations have also drawn much attention from scholars (Cornell \& Kalt, 2005; Goodman-Draper, 1994; Austin, 2013). This dissertation research fills the literature gap by focusing on the Florida Tribes.

This research highlights the priorities of sustainable economic development from the perspectives of the Seminole and Miccosukee. Those public administrators who wish to bridge the divide between U.S. policy and the needs of the Miccosukee and Seminole tribes should understand the priorities involved. This research is undertaken from the tribes' perspective of sustainable economic development. Understanding less capitalistic atmospheres open to definitions of successful economic development can help communities both on and off tribal reservations.

There is abundant scholarship on Native American history, particularly on the history of U.S. policies that have affected tribal governance (Johnson \& Hamilton, 1995). Such research includes the ability of indigenous people to 
decide on their own form of government, their tribal membership requirements, taxation, and administration of justice (Ortiz, 2002). The research covers tribal governance as it relates to achieving community goals and the impediments in achieving such goals. Policy suggestions for improve these conditions include incorporation of reservation interests under the tribal government, favoring cooperation over confrontation, and improving tribal political capacity to engage with outside forces (Zaferatos, 1998). Within the political realm, Zaferatos argues that tribes can build a cooperative relationship with the state, county, and local governments allowing for both tribal and nontribal interests to become interwoven. However, there are issues which may cause tension in this form of cooperation. Among such issues are the tensions emanating from mutual resentment (perceived or real) between state, local, and tribal governments. Prior research suggests that public administrators "are a part of the solution to the problem of declining trust in government because high performing government organization can play a pivotal role in building trust and fighting cynicism toward government" (Marlowe, 2004, p. 96). Public administrators should understand the views of Native American populations that may be unfamiliar to them, both to address the needs of cultural sensitivity and to understand and address resentments, regardless of cause or direction.

There are also legal cases suggesting that tribal economic development depends on the tribal entity's sovereignty over resources, regulatory standards, taxation, etc. In other words, economic development depends on selfdetermination policies (Graham, 2004). Although the U.S. government has 
broadly recognized the Native American sovereignty, some U.S. Supreme Court cases have not recognized the link between sovereignty and the right to development. The lack of recognition creates institutional and legal challenges for tribal people trying to improve their lives.

\section{Internal governance features}

Literature on economic development has traditionally recognized the importance of culture, entrepreneurship, and self-supporting structures in the community's economic progress. In the context of Native Americans, the scholarship on the preservation of tribal culture is abundant, often suggesting that at the federal level there should be legal and economic protection from capitalist markets for the indigenous people (Ragsdale, 1991). The literature purports that federal officials should be stewards of the tribes. Proponents have argued for the protection of tribes from market forces and that they should be free of local taxation. However, government agencies need to be sensitive to the cultural aspects of economic development, to help the tribes.

Tribal self-governance is arguably necessary to advance economic development in Native American reservations according to their own priorities. However, tribal self-governance itself is at various levels of maturity. According to Baker (1994), who studied two tribes at contrasting levels of development, there are distinctive features of the tribes with low and high development. The tribe with higher development was governed by people who were more knowledgeable of political systems, who acted in a legislative role, and hired who were more educated. The less with lower development had a tribal council with 
political appointments, with people who did not know the political systems and were less educated.

Development scholars have suggested that entrepreneurship is another key to economic development. In his review, Naude (2013, p. 15) suggests policies should be oriented toward improving entrepreneurial ability and "reduce the need for necessity entrepreneurship." In the tribal reservations, there are barriers to entrepreneurship due to their geographical isolation and resultant lack of resources. Yet, there are many micro-entrepreneurs in the reservations who own small businesses. Colbourne (2017) argues that Native American entrepreneurship is not just about commercial development; it is also creating entrepreneurial ventures that promote history, tradition, culture and language and traditional territory. Entrepreneurship in this sense should be undertaken by Native American peoples for the benefit of Native American peoples.

In terms of support structures, the National Congress of American Indians, has been the main advocate for Native Americans concerning tribal government initiatives and policy. Founded in 1944, the NCAI works with tribal governments, citizens, and organizations for advocating the causes of the Native American tribes. According to NCAI, Native American communities are mostly rural, but the tribal governments make significant contributions to the economic health of their communities and their surrounding economies.

Native Capital Access (NCA) is another non-profit corporation that squarely focuses on economic development priorities of the Native American reservations. It is a Native Community Development Financial Institution (CDFI) 
certified by the U.S. Department of Treasury. The NCA assists in the financing of community and economic development projects, primarily in the Southwestern Native American tribal reservations. It provides capital, credit, and financial services in underserved locations. In addition, scholars have argued that the tribes should be treated as "accredited investors" under the U.S. Securities and Exchange policies, so that tribal entities could invest in other tribal enterprises through private equity or venture capital investment (Clarkson, 2008).

\section{U.S. Federal and State Governments}

The U.S. federal government has direct sovereign relationships with Native American tribes. This is a result of the first treaty negotiations, when treaties were set up at the federal level. The sovereignty has existed since before the 1835 removal of the Cherokee from the state of Georgia by Andrew Jackson. Following legal disputes after the removal, the Supreme Court affirmed Cherokee sovereignty in 1832 (Garrison \& Dobbs, 2015). The ruling reinforced the sovereignty of the other Indian reservations as well. The federal government holds the reservation lands in trust on behalf of the Indian tribes.

The Indian tribes are generally overseen by the Bureau of Indian Affairs, which is a part of the U.S. Department of the Interior. Economic development policies for the reservations are managed through the Division of Economic Development (DED). The DED offers technical assistance in three ways: (a) link tribal and Native businesses with federal and private sector procurement opportunities for creating jobs and stimulating the economy in the reservations; (b) build the legal infrastructure required for economic development; and (c) 
provide training through online primers to the tribal economic development managers. The U.S. Department of Agriculture and the Small Business Administration also have specific programs targeted towards enhancing entrepreneurship and small businesses in the reservations.

There are, however, other relationships with state and local governments that may also affect economic development outcomes. The most important is the relationship between the state governments and the Indian gaming. In 1988, the Congress passed the Indian Gaming Regulatory Act (IGRA), which governs casinos and other gaming activities in the reservations. The law circumscribed the state government's role with gaming on the Indian reservations (Cattelino, 2008, p. 3032). The Native Indian tribes' relationship with state governments has sometimes been contentious with the state governments as a result of the sovereignty of tribal governments. According to Kersey (1996, p.3), "state legislatures opposed the idea of independent tribal governments within their territories". Private cattle owners and timber stakeholders have resented the sovereignty since they could not use reservation land for private gain.

\section{Ecological Concerns}

Most Native American reservations are on ecologically sensitive lands and have geographically isolated locations. At the same time, some of the reservations have natural resources like petroleum. The Native American tribes often have symbiotic relationships with the nature, as they are economically dependent on farming. Such stereotyping of the "ecological Indian" however belies the complicated relationships between the Indian reservations and the 
environment (Krech III, 1999). Extracting and transporting natural resources, especially water, has met with great deal of resistance regardless of tribal affiliation. Recent efforts to stop both the Keystone XL pipeline and Dakota Access Pipelines (DAPL) have brought dozens of tribal entities together in an effort to protect and safeguard their water resources.

Intrusion into waterways has also affected the Seminole and Miccosukee tribal reservations. Much of their reservations are in the Florida Everglades, a vast slow-moving river in the peninsula. Draining and redirecting natural waterways for building and expanding west throughout Florida has had a devastating effect on the Everglades. Many leading environmentalists and conservationists have argued for saving the Everglades from such depredations. Prominent among them is the efforts by Marjory Stoneman Douglas, whose book "The Everglades: River of Grass" in 1947 was a pioneer in environmentalism. It reconceptualized the Everglades as a required waterway rather than a swamp that needs to be conquered. Pittman and Waite (2009) also equated the Everglades to the Rain Forests as a much needed, naturally designed, system that effectively and efficiently cleans our waterways, allowing for ecological balance throughout the waterways of the world.

\section{Summary}

In this chapter, I summarized economic development approaches particularly in the context of Native American reservations. Economic development is often posited as the efficient use of resources for the development of wealth. I also summarized the major dimensions of economic 
development of the Native American reservations. As I have highlighted, the sovereignty plays a key role in the development of the reservations. Sovereignty defines the relationship between the Native American tribal governments and the U.S. federal government. Other external relations with the federal and state governments (for example, with respect to gaming) have also influenced their development process. Many authors have also highlighted how the tribes' internal governance features are key to their economic development. Ecology has been a major concern for most tribal reservations. In the case of the Seminole and Miccosukee tribes, much of the reservations are located in the Florida Everglades, which is an ecologically sensitive area. 


\section{CHAPTER 3. METHODOLOGY}

I followed a qualitative research method because this is an exploratory study. The Seminole and Miccosukee reservations are hard to reach populations, where there is little prior study. Exploratory study seeks to identify the lived experiences and the cultural dimensions. In general, qualitative research methods give weight to people's individual experiences, addressing ontological or social questions. Luton argues that there are two reasons why public administration researchers should use qualitative research: "1) it helps us in our search for knowledge, and 2) it helps us engage personally and meaningfully with practitioners" (Luton, 2010, p. 7). Practitioners have suggested that meaningful qualitative research delivers the most relevant information in an effort to offer solutions to unresolved issues, referring to this as an "action research approach" (Luton, 2010, p. 12). Luton also suggests that we gain emic, idiographic knowledge based on an insider's perspective by using qualitative research; in this research I seek the Native American's perspective. In 2003 the U.S. General Accounting Office (GAO) found that this culturally based perspective approach aided in improving agency programs, policies, and procedures ("Ethnographic studies", 2003, p. 1). Neil deGrasse Tyson said while interviewing Katie Couric that "statistics versus personal story- the story has a larger impact" due to the vividness effect (Star Talk with Neil deGrasse Tyson, 10/23/2017). The purpose of this study is to find the Native American perspective on economic development and the policy developments needed to positively affect the economic development on U.S. Native American reservations. 
Qualitative research methods are often used in exploratory research, when there is a desire to decide the why of a dilemma where a researcher seeks in-depth understanding about a topic, providing "a window into understanding why people do what they do and think what they think" (Given, 2016, p. 20). For this study, I explored participants' thoughts and experiences of economic development, businesses that they either had, desired to start, or had experiences with, discovering what barriers or positive experiences they had by asking the questions: (a) How do you view your experience with your business within economic development for the Miccosukee/Seminole? (b) Are there things that the Tribal or Federal government can do to help in business development? (c) What is the belief of other companies that may wish to develop or partner with tribal members to set up businesses on the reservation?

Qualitative research is the best approach when trying to understand social processes in context. A qualitative study builds an understanding of the feelings or thought processes, impossible to explore through quantitative research methods (Strauss \& Corbin, 1998). For this study, I explored the beliefs and experiences of Miccosukee and Seminole economic development. This study allows the participants to articulate their understanding of economic development and to inform others of what they view as important to them. This chapter defines and discusses each of these components in connection with this study.

\section{Philosophical Foundation}

The epistemology framing this qualitative dissertation research is constructivism. This epistemological approach is a philosophy supporting 
knowledge and is "constructed" based on convention, human belief, and the social experiences of those experiencing the event. Constructivism emphasizes that different people construct meaning and understanding in diverse ways, based on personal experiences. The knowledge and understanding of an event can be completely different for each person, even those experiencing the same event at the same time (Tavory \& Timmermans, 2014). Crotty argues that "meaning is not discovered, but constructed" (Crotty, 1998, p. 15). Humans share interpreted meaning and understanding through communication with one another: "only through dialogue can one become aware of the perceptions, feelings and attitudes of others and interpret their meaning and intent" (Crotty, 1998, p. 86). The research interpretations and findings in qualitative research are situation-specific. This dissertation's research is based on the interpretations of tribal members and others who have had experiences related to economic development on Native American reservations. Of interest are the ways that tribal members made meaning of events and policies within the tribal, local, state, or federal government. How they interacted with policy makers or because of policy actions affecting economic development is complex and reflects the constructivist epistemology. In terms of analysis, the background of interpretive theoretical viewpoint gives the ability to understand the ways that tribal members understand economic development policy. This study was specifically interested in discovering how tribal members interpreted events and how this understanding guided and informed decision making about economic development. Interpretive research tradition emphasizes that researchers should explore through the 
context of those studied, through observed actions and through inquiry, rather than predisposed assumptions. Interpretive study shows that the researcher is interested in understanding how participants make meaning of a situation or phenomenon. The researcher-as-instrument helps understand the meaning. Researchers submerge themselves in the setting of the population they are studying (Esterberg, 2002). We construct all social reality, which is formed or changed by the social stakeholders involved according to constructivist and interpretive approaches. As Stake (1995, p. 99). argued, "most contemporary qualitative researchers nourish the belief that knowledge is constructed rather than discovered. ...The world we know is a particularly human construction".

Using this worldview, I used a constructivist approach to examine and understand tribal members' beliefs and experiences on reducing barriers to economic development on their reservations. Constructivist researchers should focus on a considered understanding of the meanings that people hold about the issues studied by exploring the experiences using open-ended questions (Crotty, 1998). For this study, I conducted interviews with 42 Miccosukee and Seminole tribal members, reviewed relevant documents, and continually analyzed these data to understand and construct meaning of my participants' insights and understanding of the possibility of reducing barriers to economic development.

\section{Case Study Research Design}

This section describes the background of case study research, defines case study methods, examines the relevance of case study methods, explores the characteristics and misconceptions of case study methods and describes 
case study research designs as coming from case study research. All components of the research design connect but are not set in stone. Maxwell used a rubber band analogy in describing qualitative design, as being something with generous flexibility but with the various parts forcing limitations on the other parts. Violation of these restrictions makes the design ineffective (Maxwell, 2012, p. 6). For this dissertation research, I relied on case study approaches prescribed by Stake (1995) and Yin (2014).

Flyvberg (2006) believed that greater number of good case studies would strengthen the social sciences, but warned that researchers should be aware of the five greatest misunderstandings about case study research: 1) theoretical knowledge is more valuable than practical knowledge; 2) generalizations cannot be made from a single case; the single case study cannot contribute to scientific development; 3 ) the case study is most useful for generating hypotheses, while other methods are more suitable for hypotheses testing and theory building; 4) the case study contains a bias toward verification; and 5) it is often difficult to summarize specific case studies.

Case study is an approach to investigation that enables a researcher to gather in-depth knowledge of various issues, events, programs, or individuals. Time and activity set up the periods, and scholars collect in-depth information during that period using various means of collecting data. For this study, the phenomenon under inquiry was economic development on U.S. Native American reservations and the impediments or enrichment undergone by tribal members. Case studies are collections of a variety of information using various data 
collection procedures. For this study, I collected data through in-depth interviews and participant observation and reviewed documents provided by various tribal members and associations where I conducted the study. Specifically, I conducted interviews using either extensive notes or digital recordings, and then transcribed the recordings into NVivo qualitative data analysis software. Other documents were either imported or notated and coded, and I reviewed the data for emergent themes. Themes developed include:

Theme 1: Participants' priorities for the purposes economic development serves

Theme 2: Participants' experiences with large outside organizations

Theme 3: Participants' concerns about outside influences on Native American sovereignty

Figure 3.1 Word Frequency Cloud

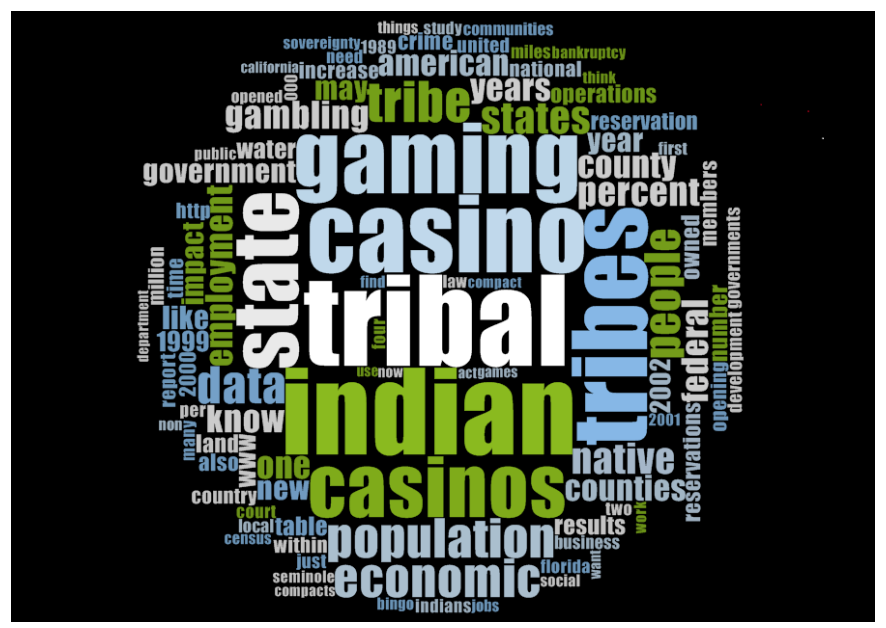

Another part of the case study approach is the unit of analysis, defined as the area of focus of the study (Yin, 2014). For this study, the unit of analysis were 
the tribal reservations, Miccosukee and Seminole. The word cloud in figure 3.1 illustrates the frequency of words taken from the interview material.

Yin (2014) names five components of effective case study research design: 1) research questions; 2) propositions or purpose of study; 3) unit analysis; 4) logic that links data to propositions; and 5) criteria for interpreting findings. The most appropriate questions for this type of qualitative case study research are "how" and "why" forms of questions. Specifically, I asked tribal members how they view economic development, and about attempts to assist economic development by tribal or outside governing forces. I also made inquiries as to their views on partnerships with non-tribal entities.

The second part of case study research design is to define the study purpose. The purpose statement is the part most commonly recognized. My purpose in this case study is to understand the experiences of the tribal members, and how these experiences have shaped economic development. The third part of the case study research design is the unit of analysis. Yin (2014) described the unit of analysis as the area of focus that a case study analyzes. I directly tied my research questions to the unit of analysis. This study's units of analysis are the reservations (cases studied); specifically, the Miccosukee and Seminole reservations.

The fourth part of the case study research design is to connect data to propositions, making connections following the data collection phase, as themes appear. Analyzing data, the researcher tries to match patterns that appear in the data to the theoretical propositions of the case study. The themes that appeared 
in this study served to answer the research questions posed in Chapter 1 . The fifth part of case study design includes the criteria for interpreting findings. The case study researcher codes the data prior to developing themes (Yin, 2014). Following the theme development stage, I carefully extracted meaning from the findings to formulate recommendations for practice and future research.

\section{Institutional Review Board Process}

Florida International University mandates Institutional Review Board (IRB) approval for any research which involves human beings. This research was approved by the IRB under exemption category \#3, which involves interviews, surveys, observations and public officials or candidates. There were no risks of discomfort of participants nor were there any risks of criminal or civil liability or damage to participants' financial standing, employment or reputation. There was no deception of the participants. No health questions were asked. Questions relating to personal identity were also not asked.

All participants were read the adult verbal consent to participate in this research and agreed to participate. The document which was read is located at the end of this dissertation. All participants were assured of anonymity and that their information would be kept confidential. All participant information was kept in an encrypted password protected file, with no other person having access to that file or information. Participant information was coded for use in this report which could be linked back to the master file, but no identifiable data is used in this dissertation. Participant content is coded using the designations of $S(X)$ for Seminole or $M(X)$ for Miccosukee where $X$ is a number assigned in the master 
table. This designation assures anonymity. Any hard copies of personal information were destroyed after the use as expressed in the IRB documentation.

\section{Research Site}

Fortunately, there were no barriers to finding suitable research locations to conduct this study. Since the nature of the study was to understand what promotes or impedes economic development on U.S. Native American reservations, I chose the Seminole and Miccosukee tribes because of their successful efforts in economic development as compared to other U.S. Native American reservations. This study also resulted in benefits for me: as the researcher of the study, I was interested in the overall results of my research. As a child of a Native American father and a student of public administration, it was enlightening to learn about tribal culture and beliefs through the eyes of the participants. Making connections with the tribal members gave me comfort in learning that there was still a level of shared experiences and understandings that I had not lost.

\section{Participants}

I used purposeful sampling (Maxwell, 2012) to select participants for the personal interviews. The choices were based on information learned during participant observation and conversations gleaned during these events. The choice of participants for this study was based on a strategy referred to as, "purposeful selection", which Maxwell suggests is a setting, person, or activity selected deliberately to provide information that through other choices you 
cannot achieve as well. Selecting members for this study was purposeful, in that they were either leaders of their respective tribe and would be able to share information about views on economic development or would be able to direct me on best understanding cultural differences. Others of interest were those members that have either worked in management of private or tribal businesses or those who wanted to start private business but experienced difficulties, both resolved and unresolved, that they could share. These individuals would be able to share these complications and their resolutions or instances needing further resolution. Since all these circumstances allow for the understanding of growth or opportunities for growth, they were all of value.

Table 3.1 Interview Breakout by Tribe/Gender

\begin{tabular}{|llrr|rr|}
\hline & Gender & Count & Totals & $\begin{array}{l}\text { Percentage } \\
\text { Of Tribal } \\
\text { Population }\end{array}$ & $\begin{array}{r}\text { Percentage by } \\
\text { Gender }\end{array}$ \\
\hline Miccosukee & Male & 7 & & 1.50 & 77.78 \\
& Female & 2 & 9 & & 22.22 \\
\hline Seminole & Male & 14 & & 0.35 & 60.87 \\
& Female & 9 & 23 & & 39.13 \\
\hline Other & Male & 6 & & N/A & 60.00 \\
& Female & 4 & 10 & N/A & 40.00 \\
\hline & Total Interviews: & 42 & & 64.29 \\
& & & & & 35.71 \\
& & & & & 100 \\
\hline
\end{tabular}

Table 3.2. Age Distribution of Interviewees

\begin{tabular}{|r|r|r|r|rr|}
\hline $\begin{array}{r}\text { Percentage } \\
18-25 / \text { Total }\end{array}$ & $\begin{array}{r}\text { Percentage } \\
\text { 26-35/Total }\end{array}$ & $\begin{array}{r}\text { Percentage } \\
\text { 36-40/Total }\end{array}$ & $\begin{array}{c}\text { Percentage } \\
\text { 40- } \\
50 / \text { Total }\end{array}$ & $\begin{array}{c}\text { Percentage } \\
\text { Over } \\
50 / \text { Total }\end{array}$ & Total \\
\hline 14.29 & 21.43 & 7.14 & 14.29 & 42.86 & 100 \\
\hline
\end{tabular}


Tables 3.1 and 3.2 show demographic information about interviewees. The 'Other' group in Table 3.1 indicator relates to those who were not Miccosukee or Seminole members but work with or for the tribal governments in some role or may be from other tribes that are married to Seminole or Miccosukee members. Table 3.2 presents the interview demographics as a total of all interviews by age group rather than gender.

\section{Data Collection Methods}

Yin (2014) suggests that a well-conducted case study benefits from having multiple sources of evidence, which ensures that the study is as strong as possible. The concept of methods refers in general to the proper use of techniques of data collection and analysis. In a case study, it is important to converge sources of data, also referred to as triangulation, which ensures comprehensive results that reflect the participants' understanding as accurately as possible. Added sources of data allow the case study researcher to create a story that honors participants' meaning-making processes. Based on the scope of this research, I selected interviewing as the primary data collection vehicle, and then thickened the data with more data points: interviews with non-tribal business collaborators and participant observation.

As a rule, I conducted interviews carefully to ensure a reliable case study. I conducted purposeful sampling, including the consideration of an individual versus a group focus, the sample size, and proper participants to choose for the interviews. I conducted interviews as a conversation between the interviewer and interviewee, in which the interviewer asks questions and the interviewee 
responds. I found who the "gatekeeper" of the knowledge is and was able to access the best resources to ensure as rich a data sample as possible. In this case, I found tribal business leaders, past or present, to be "gatekeepers". First because they knew the process best, and secondly, I needed their support and cooperation with the project to obtain added data.

When conducting interviews, a relationship and rapport is set up, and has to be coupled with trust if "the participants' perceptions and understanding of you and your research is to develop, creating useful and ethically appropriate relationships with them" (Maxwell, 2012, p. 102). Members of the tribal community that had participated in organized events with this researcher felt comfortable sharing information for this research. "Conversation is a nonstructured method of gathering knowledge" (Kovach, 2009, p. 918). Kovach suggests that the term interview does not capture the full essence of this approach. Participants shared their stories and their experiences, which served as the primary method of this research.

With participant approval, I audio recorded the interviews to ensure correct transcription. As a first step in the interview process, I reminded participants of the purpose of the study, their right to withdraw from the study at any time, and protection of confidentiality. Confidentiality was maintained through password protection of the file which was only located on this researcher's computer. A backup copy was stored on a USB drive, which was also password protected. I also gave information about myself to build rapport and gain the trust of the participants. I used a semi-structured interview approach with open-ended 
questions but allowed the conversation to occur organically to gain the most information offered by the participant. Probing and/or follow-up questions to encourage participants to elaborate on or clarify information provided in the interview followed. I used email often for this purpose. To ensure precision in the transcription, I reviewed each transcript while listening to the audio files. I offered the transcripts to the interview participants for their review to insure accuracy.

\section{Document Review}

Although interviews were the primary method of data collection, I also collected and reviewed documents. This method helps solidify my participants' statements and to ensure a thorough understanding of the case (Glaser \& Strauss, 1967; Esterberg, 2002). Documents included historical documents, Acts of Congress, social postings, and newspaper articles, both tribal and mainstream.

\section{Participant Observation}

Table 3.3 shows the participant observation activities. Many times, the participation solidified relationships and led to added invitations to events. The colors show the event leadership, with red for Miccosukee, white being organizers outside the tribes or in dual coordination with the tribes, and the black being Seminole. Outside organizers include organizations like the Florida International University Global Indigenous Forum working to bring the indigenous voice to the campus or non- profit organizations in the community such as the Love the Everglades organization focused on environmental issues. This 
enhanced opportunities to build relationships and meet more people, besides generating snowball sampling opportunities, done where participants are difficult to access. This is the case with many isolated populations, which include many Native American U.S. reservations. The Miccosukee population has remained a difficult population to approach.

Table 3.3 Participant observation activities

\begin{tabular}{l}
\multicolumn{1}{c|}{ Participant Observation } \\
\hline \multicolumn{1}{|c|}{ Miccosukee Events } \\
Met with Miccosukee General Council \\
Addressed Collier County Council with Miccosukee members \\
Miccosukee Arts and Crafts Festival - 2015-2016-20017 \\
Love the Everglades Symposium 2-3 day event- 2016 \& 2017 \\
Bobby C. Billie Interfaith Talk \\
Miccosukee School Days Volunteer-2016 \\
Perez Art Museum - Walk along presentation of Chain Link Chickee \\
Love the Everglades Cleanup \\
Global Indigenous Group Lunch for Walkers 2017 \\
$\quad$ Joint Events \\
Walk for future generations - 2 of the 5 day walk across Florida 2016 \\
Global Indigenous Forum: Canoeing along New River \\
Intertribal Celebration 2015-2016-2017 \\
Canoe Creation on Display - Upper Room Gallery \\
Seminole Events \\
Seminole Rezball Tournament - 2016 \& 2017 volunteer \\
Seminole Pow-wow and Tribal Fair - 2016 \& 2017 volunteer \\
Tribal Fair Organization meetings 2017 (Several weeks) \\
Shanahan House Seminole Days \\
Big Cypress Reservation Oak Tree Dedication \\
Seminole Climate Change \\
Ah-Tah-Thi-Ki Museum 20th Anniversary
\end{tabular}

\section{Data Analysis}

Qualitative research studies involve continuous interplay between data collection and data analysis (Strauss \& Corbin, 1998). For that reason, I began analysis following the first interview to begin finding patterns. Thematic analysis 
of interview transcripts followed the collection of data, giving the aforementioned themes.

This research study followed Creswell's (Creswell, 2003) six steps during the data analysis process and, although the steps are in linear order, Creswell described "an interactive practice" to analysis. The process is not a static or linear order of analysis, but recursive and iterative.

Step 1: Organize and prepare the data for analysis. During this step, I reviewed the audio tapes from interviews.

Step 2: Read through the data. This step also aligns with Esterberg's instruction to "get to know your data". I thought about the overall meaning to gain a general sense of the information and ideas conveyed by the participants.

Step 3: Begin detailed analysis with the coding process. I followed Creswell's procedure of organizing the material into segments or nodes by taking the text data and segmenting sentences into categories. I then labeled those categories with terms based on the actual language from participants.

Step 4: Use the coding process to generate a description of the setting or people as well as categories for analysis. I used this process to generate codes for the descriptions, which then led to generalizing a small number of categories or themes.

Step 5: Advance how the description of the themes represents the qualitative narrative. For this step, I intertwined the emergent themes into narrative passages, so that the findings appeared logically from the participants' responses. 
Step 6: Interpret the meaning of the data. Creswell recognized that a researcher's background plays an important part in the meaning-making process. During my own interpretation process, my experiences informed my understanding of the participants' stories. I focused particularly on what they were saying, the conclusions they drew, and their intentions. The themes that appeared from this study came directly from my awareness of the healthy tension between my own biases and the participants' attempts to inform during interview.

\section{Triangulation of sources}

Because qualitative research entails the researcher taking an active role in the collection and interpretation of others' thoughts, to be credible, qualitative researchers should be good and trustworthy. Stake (1995) warned qualitative researchers against narrow thinking, and instead suggested that researchers learn to understand their research as their participants do, rather than imposing their own assumptions. In qualitative research, these protocols come under the name of "triangulation" (Maxwell, 2012, p. 110).

To increase the trustworthiness of the study's findings, I employed strategies suggested by renowned qualitative researchers. To decrease the threat to credibility, I triangulated data using multiple sources of data (Maxwell, 2012; Stake, 1995; Yin, 2014). I performed added member checks by sending participants a copy of their interview transcript and asking them to verify the accuracy of the content as well as requesting them to review my findings as they emerged. To increase dependability, I kept notes of data collection and analysis methods, including how I made decisions. 
A sound case study is significant and complete, uses alternative perspectives and enough evidence, reported in an engaging manner (Yin, 2014). In addition to triangulation, and member checks, Maxwell (2012) recommends that credible and trustworthy researchers also ensure the following qualities.

Reflexivity: the influence of the researcher on the setting or individuals studied—engaging in critical self-reflection about assumptions, biases and the relationship to the study, which may affect the investigation.

Engagement: allowing for suitable time to collect data, such that it allows for saturation.

\section{Researcher Positionality}

One important distinction between qualitative and quantitative research is the role that the researcher plays in the process. The primary instrument for data collection and analysis in case study research is the researcher. As a researcher progresses through the research process, the researcher must acknowledge they are an instrument and the primary research tool. It is important to consider their own biases, limitations, and views throughout the data collection, interpretation, and reporting phases of the process. Qualitative research assumes that researchers' biases and values affect the outcome of the study; however, as communicated by Maxwell, "validity in qualitative research is not the result of indifference, but of integrity" (Maxwell, 2012, p. 135). To allow for any audience to evaluate the validity of conclusions extrapolated from the data, researchers should counterbalance their biases by stating them explicitly and as fully as possible. "The key issue is how plausible and how serious these unavoidable 
threats are" (Maxwell, 2012, p. 146). For this study, in the interest of full disclosure, intending to guard against unethical or unintentional influences on my interpretation of what influences impact economic development on Native American reservations, the following discussion outlines my experiences germane to this study.

My ethnic background includes a Native American lineage. My father was of the Lakota tribe, while my mother was German American. My father was born in 1909 in Oklahoma, which became the "Indian Territory" following the U.S. government's policy of moving Native American populations to the Oklahoma territory. The circumstances of his childhood are mostly unknown, since he refused to discuss his heritage for fear that the government would take his children. We did not understand his reasoning until this research happened, where I learned that the taking of Native American children for adoption by nonNative families occurred quite often. Therefore, my inclination has been to accord credibility to what the interviewees said, using triangulation to confirm. I grew up in the Midwest and as an adult became aware of Native American populations and issues. I moved to Florida over thirty-five years ago and routinely attended the Seminole pow-wows, ensuring that my children were aware of their connection to the culture and the traditions that I could enlighten them about.

\section{Limitations and Delimitations}

There are limitations and delimitations to this study. Although I conducted the study at various locations in association with the Seminole and Miccosukee tribes, limits to the scope of the study included those involved in business and 
economic development or governmental association with business and economic development of the Seminole or Miccosukee tribes. To bring depth to the data, I included others who may not currently be involved in business or economic development but have tried to start businesses. Since information obtained during the interview was dependent on the interviewees and what they were willing to share, limits on the nature of their information arise from the fact they reflect their own perspective and lived experiences.

There are delimitations, that is, the narrow scope of the study (Creswell, 2003). Some consider using only two Native American tribal reservations a delimitation. Although you could gain a distinct perspective collecting data from each recognized tribal reservation, each tribal reservation varies from other reservations, whether of the same size, larger, or smaller. For that reason, I discourage speculation that this study's results would be like that on any other reservation. Data sources, which included semi-structured interviews, participant observation, and then relevant documentation review, added to the narrow scope of the study.

\section{Summary}

Chapter 3 outlined the epistemological and theoretical grounding, the methods used for this study, and the ways in which these decisions affixed the research design and process of analysis. I described the constructivist paradigm along with the rationale for qualitative research methodologies. This chapter also gave the rationale for the methodological decisions for this study. The theoretical perspectives and methods helped to illuminate the various intricacies and 
experiences of the tribal members included in this case study research:

economic development process, analysis, and problem-solving with respect to governmental/intergovernmental issues, impairments, and resolutions used. The chapter concluded with a discussion of the strategies used to enhance the trustworthiness of the findings. The next chapter presents a brief history of both the Seminole and Miccosukee tribal governments. 


\section{CHAPTER 4. HISTORY OF THE SEMINOLE AND MICCOSUKEE}

\section{TRIBES}

\section{Introduction}

Knowledge about the history of the Seminole and Miccosukee gives the background to which the current condition of these tribal governments could be attributed. This background follows the history as understood from the literature and the interviews conducted. Much of the history is well documented. It should be noted that there are some individuals in both reservations who have not registered as either Seminole or Miccosukee. As one participant explained, some do not believe in registering, feeling that they do not need recognition to know that they are Native American, whereas others still do not trust US officials and are "hiding in plain sight". They retain their tradition and history as the Sovereign Miccosukee Seminole Nation, also known as the Everglades Miccosukee Seminole Nation, unrecognized by the US or Florida government. This traditional government holds the tribal members as the general council and the representatives of the eight clans to be the executive council. Three co-chairmen act as authorized spokespersons to attend to matters. The constitution reads Constitution of Everglades Miccosukee Tribe of Seminole Indians, while other documentation shows the original name as the Sovereign Miccosukee Seminole Nation (MSN) (1951-2004). 


\subsection{Seminole History}

The Seminoles of both Florida and Oklahoma are believed to be descendants of the Creek Nation. In the mid-1700s several small groups and families of Creek members left the area now known as the state of Georgia and settled along the grassy plains in the area of southern Georgia and northern Florida, becoming known as the Seminoles (Alderson, 2013). Maskoki tribes in Alabama, unhappy with outcomes forced upon them by Andrew Jackson, migrated to Florida, where they joined members of other tribes in Florida.

Those Native Americans who collected in Florida thought of themselves as "yat'siminoli" or free people, because their ancestors battled for so long to resist attempts by both the Spanish and English settlers to "conquer and convert" the various indigenous populations. During negotiations with the British, the Oconees, the Hitchiti speaking people, desired treatment as an independent tribe from other Creeks to the north, earning them the name Semanoles or Seminoles as early as 1765 . Loosely translated, the term Seminole means renegade or rebel. Seminole members say the term means wild, as in wild boar. Eventually, the U.S. population would call the collective group of Native Americans in Florida "Seminoles" (Weisman, 1999). The Seminole people state that following the Spanish landing on la Florida, they attempted to use Indian labor for their cattle production. The Spaniards saw Indians leaving their villages, families, and clans to escape Spanish control. The Spanish called them cimarrones, or runaways, because they refused to stay where the Spanish wanted them. When the Indians pronounced this word in their native language, the English heard it as 
"Seminolie", pronounced today as "Seminole". The Hitchiti are now known as Miccosukee and Maskoki, now commonly referred to as Creek.

Author and historian Patsy West states, "there are two distinct, unintelligible languages spoken by the Florida Indians: Mikasuki (i:laponathli) and Creek (or Muscogee)" (West, 1998, p. 8). There is speculation that these distinctions are what divide the two culturally similar people. Alderson states that the Miccosukee spoke a language descended from the lower Creek Indians while many Seminoles spoke Muscogee, a language of the upper Creeks. In 2000, some estimated that there were 200 Seminole tribal members that spoke the Creek/Muscogee language and 1600 the Mikasuki language (Cattelino, 2008, p. 1233).

Political differences also distinguish the two tribes. The Miccosukee sought separate recognition from the Federal government, which happened in 1962. This political difference referred to the differences in "whether and how to reorganize" following the 1934 Indian Reorganization Act (IRA). There are suggestions that the authorities forbid Seminoles from living within the Everglades National Park in 1947, thereby forcing many to move their communities (Cattelino, 2008, p. 493). The Miccosukee were more traditional families who kept camps near the Tamiami Trail, adamantly opposed to earlier dealings with the federal government. Miccosukee members viewed earlier dealings as compromising their lifestyle and they vehemently opposed a $\$ 50$ million claim filed with the Indian Claims Commission by a group of Seminoles living on a Seminole reservation (Kersey Jr., 1996, p. 19). The Miccosukee did 
not want money, they wanted the return of land, including the land seized when the Seminoles were removed from Florida in the 1800's.

On October 1, 1953 Ingraham Billie, the official interpreter at the time for the General Council of the Seminole Indians of the State of Florida, with witnesses Leo M Alpert and Buffalo Tiger, sent a notarized letter stating that they have "no desire or intent, now or in the future, to accept money from the United States Government". The 1954 Miccosukee Seminole Nation "Buckskin Declaration of Independence" was hand delivered to then President Dwight D. Eisenhower followed. The Declaration indicated that US treaties with Spain, in 1821, agreed to recognize property rights to lands "recognized by Spain". The following excerpt expresses the displeasure the Miccosukee felt on payment for the land taken by the US Government:

We, the Mikasuki Tribe of the Seminole Nation, have made.no requests of any kind upon your government since the McComb Treaty of 1839. We have never asked for not taken any assistance, in money or in any other thing, from your Nation. We have for over one hundred years lived on lands in the Everglades, some of which were established as Indian Reservations, and for over one hundred years we have not been discontent with our relationship, because you let us alone and we left you alone. For over one hundred years we have not allowed the conduct we have received from your government to disturb us in spite of many insults to our Nation, chief of which has been the deliberate confusion of our Mikasuki Tribe of Seminole Indians, governed by our General Council, with the Muskogee Tribe of Seminole Indians in order to avoid recognition of our tribal government, independence, rights and customs. Now, and for the first time in over one hundred years, we are obliged to address ourselves to your government. There has been filed before the Indian Claims Commission in your government, without our authority, a claim, supposedly by us, and supposedly to compensate our Tribe with money for lands taken from us by the United States Government in the past. We want no money. 
Ingraham Billie, Sam Jones Mico, Jimmie Billie, Oscar Hoe, Frank Charlie, Jimmie Henry, William Jim, George Osceola, Jack Clay, and Tommy Buster signed the buckskin as translated, interpreted, and seen by Buffalo Tiger. The Buckskin, which was recovered from the garage of one of Eisenhower's aides and placed into the Dwight D Eisenhower Presidential Library in Kansas, was on loan to the Ah-Tah-Thi-Ki Museum in 2016. Figures 4.1 and 4.2 are the flyer for the event and a picture of the buckskin declaration.

Figure 4.1-4.2 Event flyer and picture of original Miccosukee
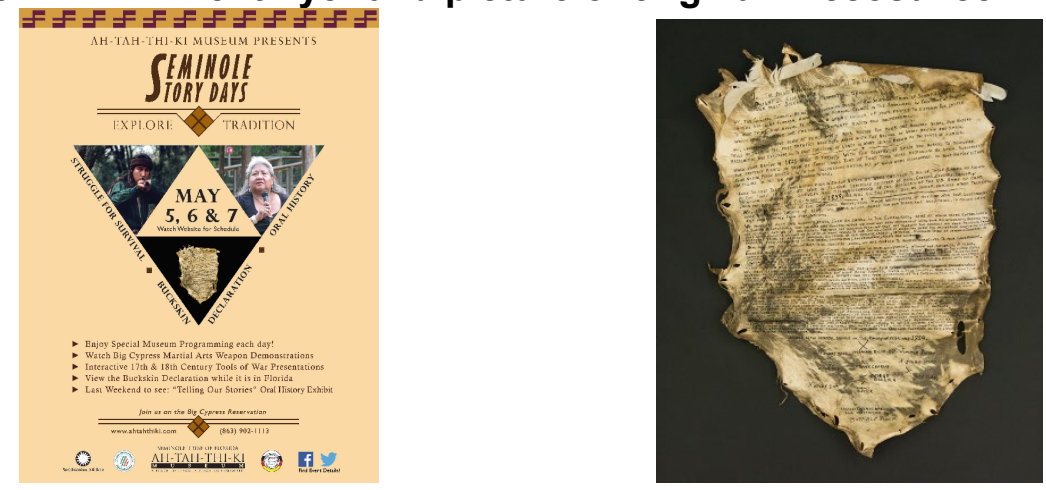

Source: Ah-Tah-Thi-Ki- Museum

It appears that the Miccosukee Tribe of Florida and the Miccosukee

Seminole Nation of Florida started as the same group. Indian Claims Commission Docket No. 73-A refers to a settlement offer of fifty thousand dollars $(50,000)$ in exchange for 99,000 acres of Everglades National Park and 104,000 acres in Broward and Palm Beach counties. This document indicated that 400500 members of the Seminole Tribe of Florida lived on each of three reservations and two other groups, 400 members of Miccosukee Tribe of Indians of Florida on state reservation in southern Florida and the Everglades Miccosukee Tribe of Seminole Indians, 40 persons in and around Naples Florida. The two other 
groups referred to are not affiliated with the Seminole Tribe of Florida according to the document (Indian Claims Commission: Additional Findings, 1977).

The Seminole Tribe of Florida has several reservations throughout Florida. Each has various enterprises including casinos on the reservations in Tampa, Brighton, Hollywood, Immokalee, and Coconut Creek, Florida. Figure 4.3 is a map identifying the various Seminole reservation locations. The Seminole Tribe also offers cultural tourism operations on several Seminole reservation locations. Some reservations have campsites, fish stocked lakes for fishing, airboat rides, rodeos and gift shops. The Seminole also have citrus groves and cattle production enterprises.

Figure 4.3 Seminole reservation graphic

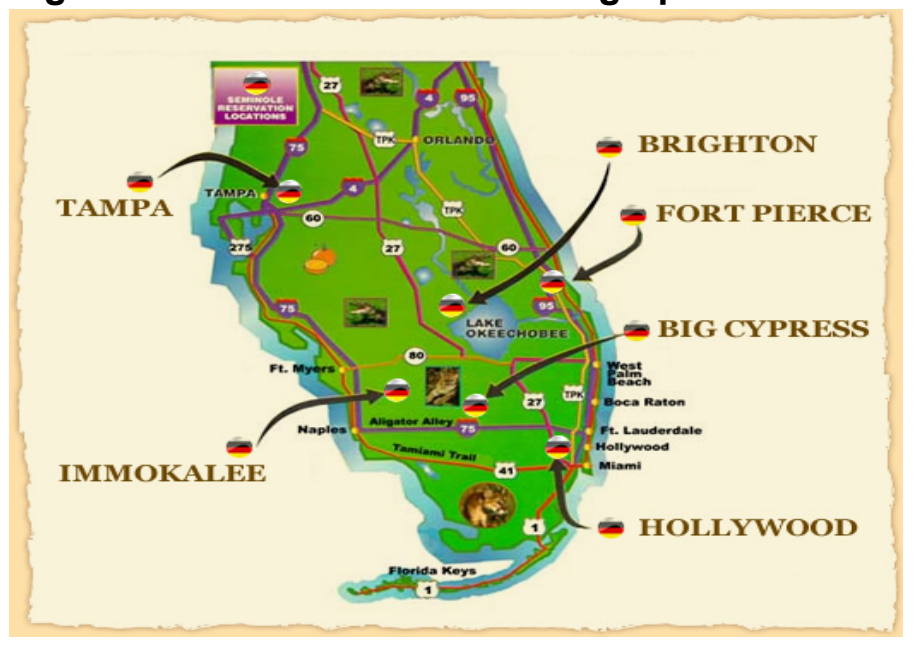

Source: Seminole Web Page

When the Indian Removal Act happened, the effort to move approximately "3000 men, women and children from Florida to the Oklahoma" started the second Seminole war ("Seminole History," n.d., para. 7). Following the last of three Seminole wars, the Seminole people, using their hunting, trapping, and 
fishing skills to sustain themselves, remained in Florida. They also set up trading with non-Native populations at frontier outposts and they became the premium tourist attraction of Florida, living in villages on display (West, 1998).

The cultural tourism of the early 1900s through the 1930s was more about tribal crafts produces by tribal members, sometimes as part of a tourist experience of watching Native Americans in their natural element. The tribal members would carve dolls, cypress canoes, and chickees, which are thatch covered traditional Seminole housing. They still wear Seminole patchwork clothing, sewn today. Alligator wrestling is still displayed as a traditional cultural skill and performed for audiences (West, 1998); these demonstrations continue at the Seminole tribal fair and the Miccosukee village.

In the early 1920 s the Seminole economy suffered as non-indigenous populations continued to migrate into Florida, having a negative effect on crops, fish, and game, compounded by the effects of droughts and serious hurricanes. Many Seminole and Miccosukee families worked in cultural tourism villages often set up by non-native business and property owners. Some indigenous members from the tourism villages also traveled around the U.S. to several World's Fair operations, promoting Florida with the Miami Chamber of Commerce's Everglades Committee under Ernest R. Graham (West, 1998, p. 1423). Utilizing the Seminole attraction, Ernest Graham would promote Florida's newly reclaimed land, specifically the towns of Opa Locka and Hialeah which are two cities in South Florida with names originated by Native Americans. Opa Locka started as "Opa-tisha-wocka-locka", meaning a big island covered with many trees and 
swamps. Opa Locka resulted from the shortened name. The Muskogee are the origin of the name Hialeah, meaning pretty prairie or Seminole origin meaning Upland Prairie. Florida elected Ernest Graham to the Florida Senate in 1937.

In the 1930s the Seminole population received the opportunity to move into a reserved area consisting of more than 80,000 acres of land in the Big Cypress National Preserve, Hollywood, and Brighton areas of Florida. Due to both the distrust of government intentions and the fact that the Seminole people did not want dependence on government, few Seminoles moved onto those reservation areas at the time. Some believed that moving onto the reservation land was a ploy to collect them into one area where the government would then force them westward to present day Oklahoma (Cattelino, 2008, p. 2419).

The Seminole Tribe of Florida achieved official recognition in 1957 under the Indian Reorganization Act after creating their constitution. Their constitution set up the tribal council, which is the governing body that oversees the Seminole police department, human resources, the gaming enterprises, and other economic enterprises. The Seminole members also approved a corporate charter, which oversees "further economic development of the Seminole Tribe of Florida" by conferring upon the tribe certain corporate rights, powers, privileges, and immunity to secure economic independence and to provide for the proper exercise by the Seminole Tribe of the various functions previously performed by the Department of Interior (Seminole Board of Directors, n.d., para. 3). The Seminole nation has kept a cattle production company since before the USA came into existence. Records show that upon the arrival of cattle with Spanish 
ships in 1521, the Seminole leader known as "Old Cowkeeper" developed a herd in the Alachua prairie numbering $7,500-10,000$ head. The Seminole people throughout the $1600 \mathrm{~s}-1700$ s maintained vast herds of cattle and wealth. Settlers and the U.S. Army, according to Seminole records, presented a constant threat of cattle rustling. When the Indian Removal Act of 1830 was promulgated, along with the Seminole Wars, destruction occurred of both the tribal members and the cattle herds. As the Seminole said, "the tribe went from 5,0000 homesteaders to 200 fugitives within a generation, lacking the resources to farm or ranch" (Seminole Pride Beef, n.d., para. 3). Federal authorities assigned reservation land in the 1930s, and donations of 400 head of cattle were given to the tribe in 1957, with individual owners dividing the herds following federal recognition. In the 1960s the University of Florida worked with the tribe and the Seminole cattle owners and started the cattle program. The Seminole have worked with the USDA's Natural Resources Conservation Service (NRCS) since the early 1980s. By 1982 the cattle operation exceeded 15,000 cattle on 30,000 acres.

In 1973, the Seminole Tribe sought compensation from Florida for 16,000 acres of reservation land flooded in Conservation Area No. 3. Since Florida had donated the land to the Seminole, the compensation for flooding the 16,000 acres of easement, Florida contended, belonged to Florida, not the Seminole nation, since the land was under Florida title before donation. In 1974 the Seminole filed litigation contending that the land was originally the property of the Seminole Tribe. In 1985 the Seminole Tribe threatened to oppose South Florida Water Management Districts' (SFWMD) construction of the $\$ 20$ million flood 
control project planned by the Corps of Engineers (Godfrey \& Catton, 2011, p. 230). In 1986 Florida paid a settlement giving the Seminole $\$ 11$ million in return for withdrawing any objections to the threatened project. A compact recognized the Seminole tribal request for water rights, acknowledging the responsibility to preserve water quality and setting up a tribal water department with water code. Seminoles took responsibility for water management on their reservations. The compact recognized tribal sovereign power to administer reservation water resources, according to legal counsel for the Seminole Tribe, contrary to the subordination of tribal interests that SFWMD desired. The Seminole Indian Land Claims Settlement Act of 1987 states that the compact has "the force and effect of Federal law for the purposes of enforcement of the rights and obligations of the tribe" (Doc No. Public Law 100-228, 1987, p.5).

Standing Rock was the site of one of the largest actions tribal people have taken to bring awareness to mainstream populations about water insecurity. For Native American populations, there is a basic concern about water use and contamination. When tribal people suggest "protect the sacred", the sacred is the very essence of life, water. The Dakota Access Pipeline (DAPL) is an oil transportation system of pipes installed under Lake Oahe and the Missouri river. This is upstream from the Standing Rock Sioux reservation, and is the waterway that feeds the reservation's water supply. The concern for the reservation population is that when, not if, the pipeline leaks, it will contaminate the water that feeds the reservation. As of May 2017, the pipeline had already suffered three leaks. On March 3, 2017, 84 gallons leaked affecting snow and soil, 
sparing the waterways and wildlife. On March 5, 2017, another 20 gallons leaked due to an above-ground valve malfunction. On April 4, 2017, another 84 gallons of oil leaked before containment (Rice, 2017). On April 23, 2017, 168 gallons leaked near Patoka, Illinois, causing soil contamination and removal. On November 14, 2017, 21 gallons spilled from a welded crack at a pump station (Brown, 2018). So far, there has been no water contamination, nor enough leaking to be categorized as "significant", which is 210 gallons or more.

Those people watching Native American activity saw this issue grow aggressively. This was the first time in 140 years that all seven Sioux tribes of the Sioux Nation came together. The Battle of Little Big Horn, resulting in the destruction of General Armstrong and his troops, was the last previous instance when this had happened. They joined peacefully on this event to protect the water (Mike Anderson Journal Staff, 2016).

S2 suggested that the tribal populations on reservations, where there are oil reserves, have divided views about the issue of pipelines. Some reservation occupants want the funds that the oil reserves can give, while others feel that the dangers outweigh the profits. Surprisingly, the differences between the tribal populations, according to S2, are comparable to the conflicts in northern Iraq, often summarized as conflict over who should control the money within the area.

\subsection{Miccosukee History}

There was one tribe prior to 1961 consisting of Seminole and Miccosukee people, so that the advancements of the Seminole nation prior to 1961 were advancements for the Miccosukee as well. The US government slighted the 
Miccosukee when they first sought independent recognition, viewing them as just another faction of the Seminole Tribe. In 1959, two years after Seminole recognition and shortly after Fidel Castro took control in Cuba, the then tribal leader Buffalo Tiger, along with other Miccosukee officials, visited Cuba and the Cuban government recognized them as an independent nation (Kersey Jr., 1996). This caught the attention of the U.S. government, which resulted in federal recognition of the Miccosukee tribe in 1962, with the tribe agreeing that they would not travel to Cuba again. Many believe this to have been a calculated political move on the part of Buffalo Tiger, while others believe that it just so happened this had a positive political outcome despite lack of intent.

The Everglades Miccosukee Tribe of Seminole Indians are the group that traveled to Cuba (Kersey, 2001). The Miccosukee Tribe of Indians of Florida separated from the Everglades Miccosukee Tribe of Seminole Indians in 1961 and organized the third tribe in 1962. Homer Osceola said that "the US Department of Interior is pushing ahead with its plans to organize a third tribe of puppet Indians to wreck the many years of negotiation and agreements with our Miccosukee Tribe" (Siniard, n.d., para. 27).

The "Original Miccosukee Simanolee Nation of Florida" indigenous members not enrolled in either Tribe, exist as "independent". The U.S. or Florida state governments do not recognize this group, because they refuse to register as either Seminole or Miccosukee. They continue to claim Florida land as their rightful land. All three groups, Seminole, Miccosukee and independent or Original Miccosukee Simanolee, all recognize one another as relatives (Cattelino, 2008). 
These families show the independent traditional faction forming a community at Immokalee "after fifty years of strife reconciling their traditional systems of governance with the political realities of a modern world" ("An Understanding," n.d., para. 4).

Figure 4.4 Miccosukee Reservation map

\section{Tamiami Trail}

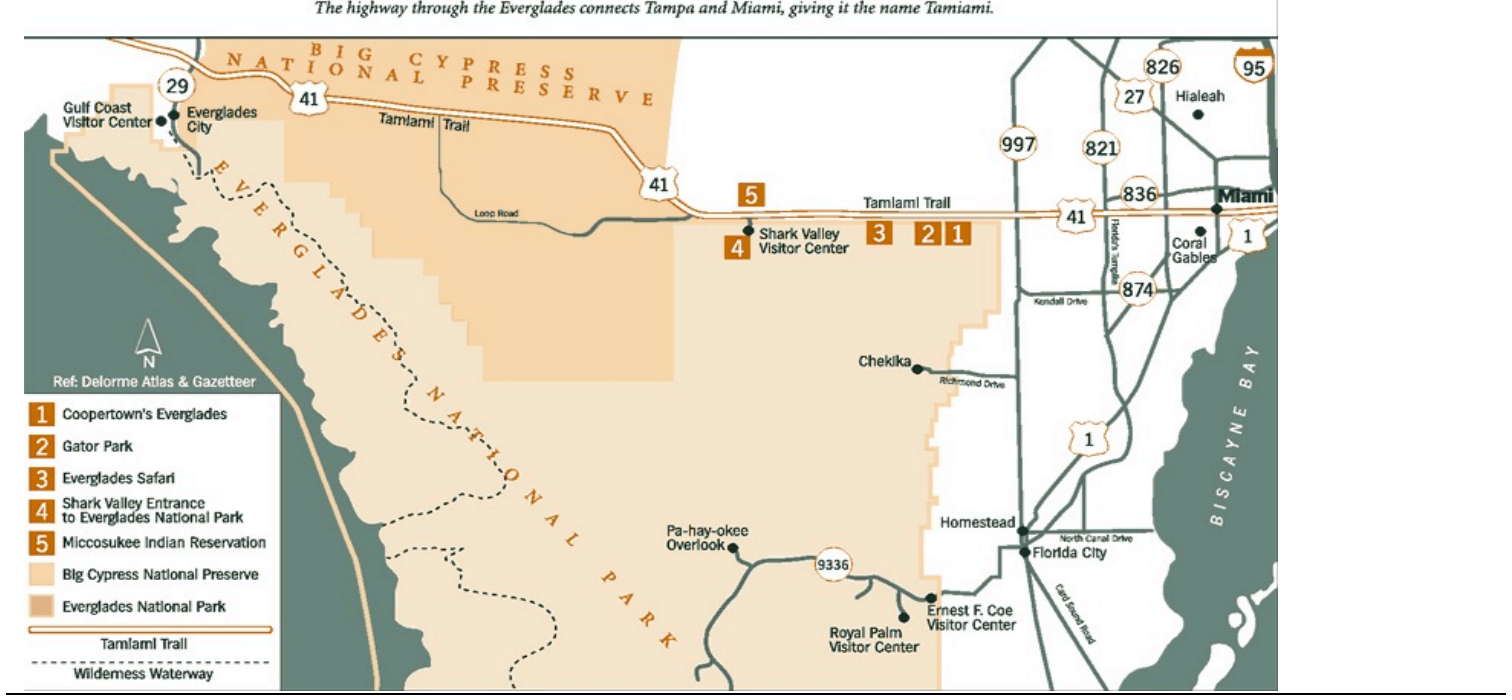

Source: Miccosukee Web Page

The Miccosukee reservation consists of four parcels of land found on

Tamiami Trail, as shown in the graphic above (Figure 4.4). Traveling west from Krome Avenue on U.S. 41 you enter onto the Tamiami Trail parcel which is five miles long and 500 feet deep. It was originally under a 50 -year use permit from the National Park Service, but under the 1998 Public Law 105-313, also titled Miccosukee Reserved Area Act, the land was placed into exclusive right to use and develop by the Miccosukee people (Public Law 105-313, 1998). The Tamiami Trail reservation is the area most Miccosukee families occupy. The 
names of the villages are "Indian Village" or "Indian Family", marking the driveway entry to the family home. Alligator Alley is the largest reservation area. The Alligator Alley Reservation is $74,812.37$ acres, found west of Fort Lauderdale on the north and south sides of State Highway 84 (Alligator Alley), although 55,000 acres of this are wetlands. This location has the Miccosukee Service Plaza, which is a modern service station with gasoline and diesel fuel accommodating auto and large tractor trailer vehicles, a Miccosukee police substation, and 13,000 acres of land leased for cattle grazing. This area also has 15,000 acres of tribal wetlands upon which the Miccosukee nation issues temporary occupancy and access permits. Figure 4.5 shows the reservation area in dark blue.

\section{Figure 4.5 Miccosukee Reservation Location}

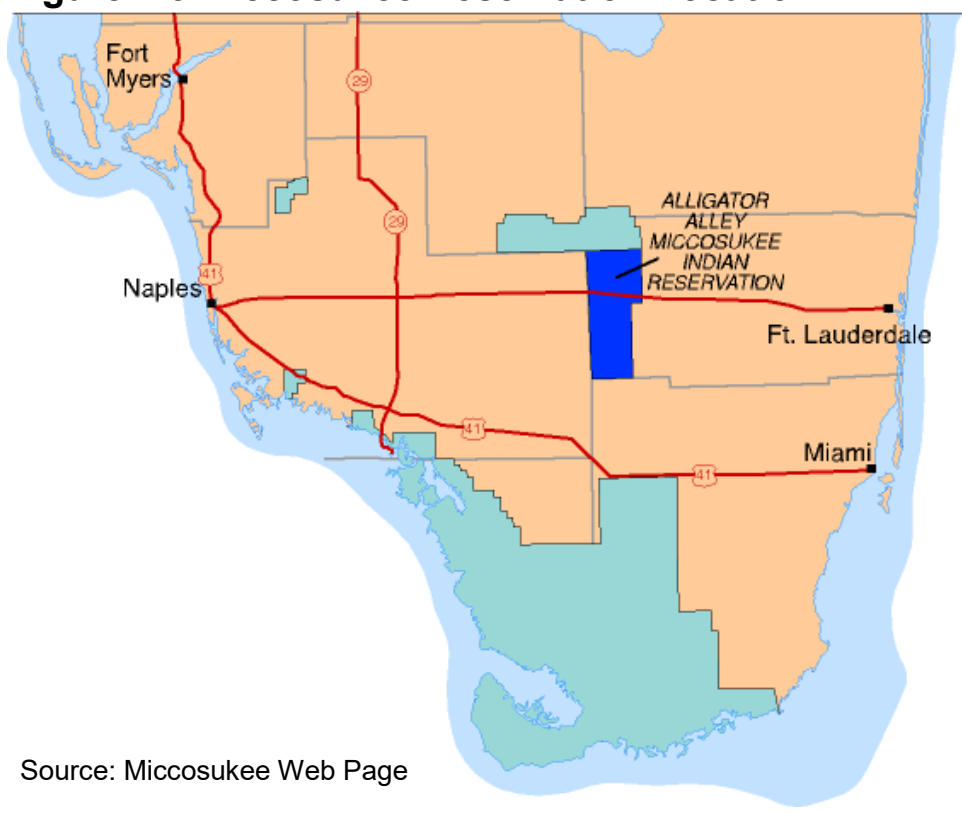

The permits are for non-Natives who keep hunting camps which they use on the land. The last are two areas at Krome Avenue and U.S. 41 on the North 
and South side of U.S. 41 or local $8^{\text {th }}$ street. They consist of a total of 25 acres found on the northwest corner which holds the Miccosukee resort and gaming facility shown on figure 4.6. The area is large enough to accommodate RV parking for those not staying in the Hotel. There is another .92 acres on the southwest corner which holds the Miccosukee tobacco shop (Miccosukee Tribe Reservation Areas, n.d.). The Miccosukee also have a perpetual lease for 189,000 acres shown on figure 4.7, used for hunting, fishing, frogging, and subsistence agriculture to ensure that the traditional Miccosukee way of life continues (FPL Socioeconomics report for Turkey Point 6 \& 7, 2010, p. 53). 
Figure 4.6 Miccosukee Casino Location

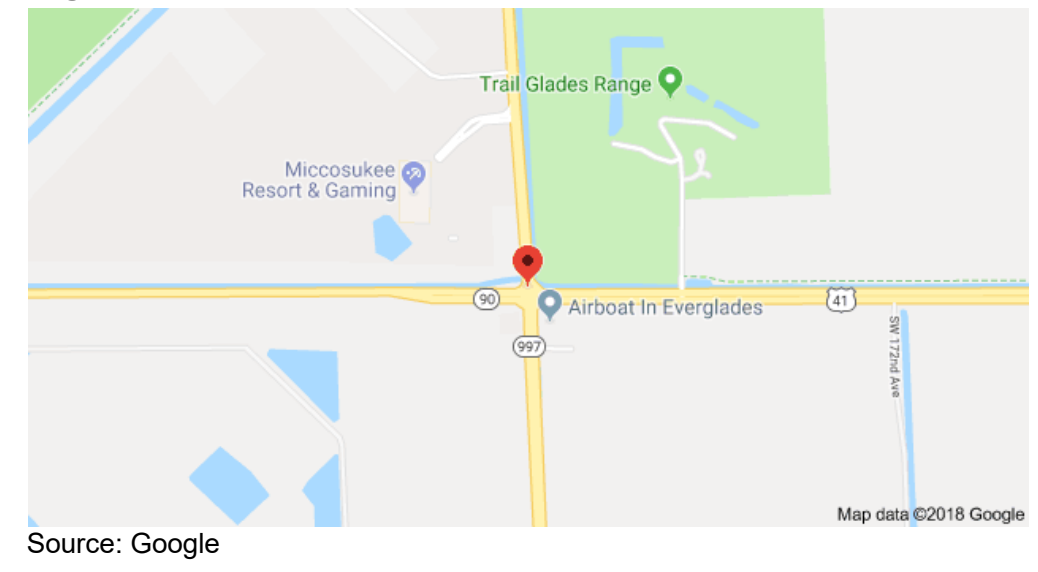

Figure 4.7 Water Conservation Map

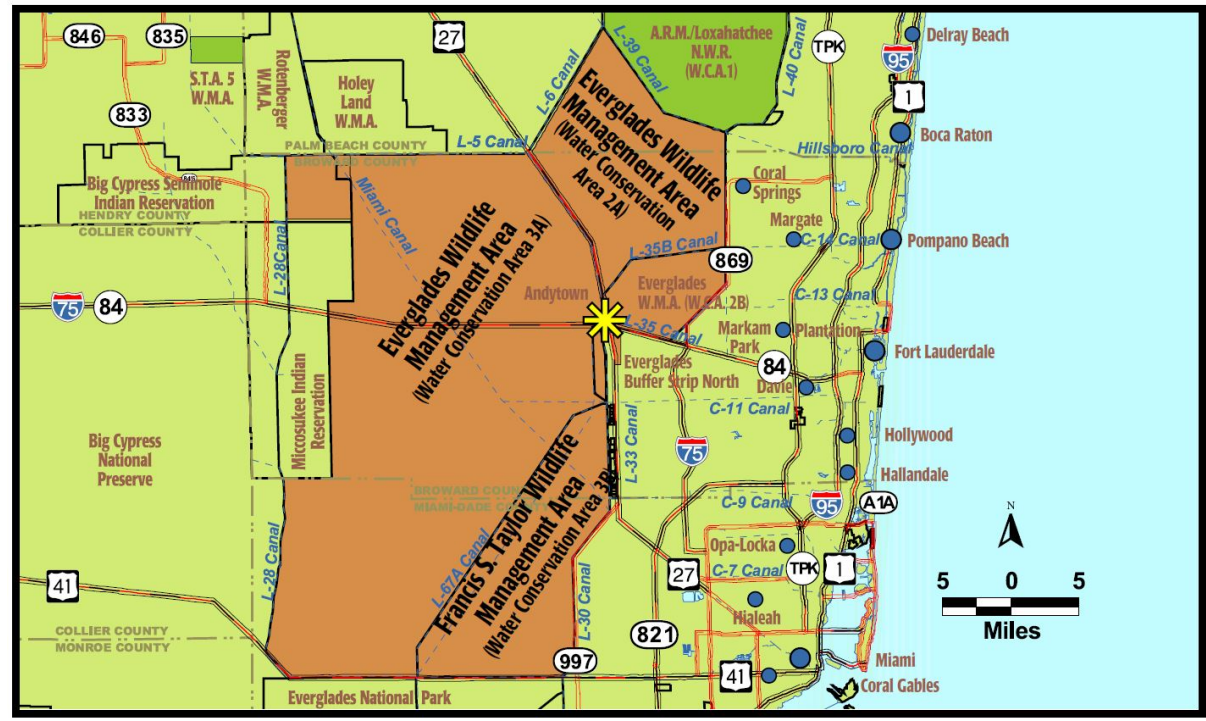

Source: SFMWD

The 1962 Miccosukee constitution set up the General Tribal Council as the governing body. The General Tribal Council needs members to be 18 years of age or older. The election of Council officers is to four-year terms, with elections taking place in November. The General Tribal Council also has a Miccosukee Business Council, overseeing the development and management of the tribal resources. Unlike the Seminole, the Miccosukee have not incorporated 
and spun the economic development off to a separate council. Buffalo Tiger ensured that they could add a separate council later and that it was not necessary at the time of establishment. The BIA also assured him that the council could be added later (Tiger \& Kersey Jr., 2002, p. 96).

Neither Florida nor the U.S. government recognizes other tribal people in Florida. Other tribes include the Panokee people, who participate in Native American rituals. They have registered on the pow-wow website for upcoming events held by them in Florida. Interviewee N1, who helps tribal entities register for recognition, said that there are a substantial number of tribal entities that the U.S. government has refused to recognize, much like the Miccosukee from before the Cuban visit. The Bureau of Indian Affairs (BIA) Office of Acknowledgment (OFA) has an active website that lists the petitions for recognition, including active petitions in process, petitions that will be in process once they provide supplementary information, and those unfortunately denied for assorted reasons. The Panokee tribe is not on any of the BIA's pages, but I did see the active petition for the Miscogee Nation of Florida, which was initiated in 2015 for Federal recognition. Indian Country Today, a web periodical for indigenous North American people, wrote an article about problems with tribal recognition. The author, Mark Rogers, showed that the largest obstacle for most tribal governments in looking for State or Federal recognition were other tribes. Limited Federal resources may force previously recognized tribes to deny petitioning tribal recognition. When discussing this issue with both Miccosukee and Seminole members, both said they would never deny anyone the right to 
recognition, but even more, it is disturbing that tribal entities must seek recognition to formally exist.

The 1985 project that the Seminole threatened to oppose concerned the Miccosukee also. Repeatedly reassuring the Miccosukee, the South Florida Water Management District (SFWMD) entered into a memorandum with the Miccosukee assuring them that no harm would come to their water quality and interests in water quality and vegetation in Conservation Area No. 3. The Miccosukee also withdrew their objection. The Miccosukee needed concessions requiring SFWMD to monitor discharges into Conservation Area No. $3 \mathrm{~A}$ and on tribal land for pesticides and water quality, as well as quarterly reports from SFWMD to the Miccosukee business council preventing "excessive nutrient enrichment". In 1988 Lake Okeechobee hit the highest phosphorous levels recorded. SFWMD proposed diverting the nutrient-rich water from conservation areas affecting Seminole and Miccosukee land. Both Miccosukee and Seminole areas experienced changes threatening fish and wildlife; melaleuca, nonindigenous trees, and cattails, another non-indigenous plant, overrun the Everglades sawgrass. The water diversion added 45.4 metric tons of phosphorus annually. The creation of a Scientific Advisory Committee for the Everglades brought state, federal, and local agencies, including Seminole and Miccosukee representatives together.

From this point forward, negotiations were separate for each Tribe. The Seminole Tribe and SFWMD continued negotiations between 1993-1995 detailing water quality on Big Cypress and Brighton reservations. Water source 
and treatment were the primary discussion points, but restricted phosphorous to $50 \mathrm{ppb}$ for water entering and leaving the reservations. Environmentalists and Miccosukee objected, together with Truman Duncan Jr., the Miccosukee Water Resources Director, recommending to both SFWMD and the Seminole that the Miccosukee intended to set phosphorus limits at $10 \mathrm{ppb}$ for the Miccosukee reservation. Research by Florida International University's (FIU) Ron Jones showed that any standard above $10 \mathrm{ppb}$ is ineffective for Everglades protection. Following protests from environmentalists and the Miccosukee, the latter requested and received permission from the EPA to set their own water quality standards, giving the Miccosukee "treatment as state" recognition under the Clean Water Act. The conditions of this permission required that the reservation water is under Miccosukee control, publication of the proposed standards, including public hearings, and opportunity for comments also applied. Both Florida Sugar Cane league and SFWMD objected to the more stringent restrictions, with SFWMD specifically objecting to the Seminole/Miccosukee difference in standards for the same body of water. In December 1997, the Miccosukee adopted their phosphorus restriction level at $10 \mathrm{ppb}$ and sent it to the EPA for approval. The approval process, which normally took sixty days, dragged on for two years. The Miccosukee received approval in May 1999.

The Miccosukee, under a special use permit, found the objections from the Everglades National Park Superintendent to the construction of housing on the land unacceptable. The Miccosukee worked with Florida legislators, Alcee Hastings and Carrie Meek, to expand the area to 660 acres and grant the 
Miccosukee rights to govern the land. Florida legislature approved the Miccosukee Reserved Area (MRA) Act in 1998. The Miccosukee applied their water quality restrictions to this area as well, affecting the Everglades National Park, with the EPA approving in October 1999.

The Miccosukee also protect the Everglades ecosystem through litigation. Lawsuits at this time state that the National Park Service, in protecting the endangered cape sable seaside sparrow, requested SFWMD to deviate from the regulation schedule of Conservation Area 3A, violating the Endangered Species Act, now threatening the wood stork and the snail kite within 3A.

There is a clear divergence in policy development and implementation between the Seminole and the Miccosukee. The Seminoles used peacemaking or appeasement, while the Miccosukee, believing the Everglades were dying and would never recover from the damage, forced attention on the issue through litigation. Several Miccosukee attended Standing Rock, collecting clothing, mostly for cold weather, and food, and traveled to South Dakota with these supplies. The Miccosukee Government sent a Miccosukee flag to fly in solidarity with the other tribal flags. Figure 4.8 below shows the multitude of flags in attendance. 
Figure 4.8 Photo of Tribal Government Flags at Standing Rock

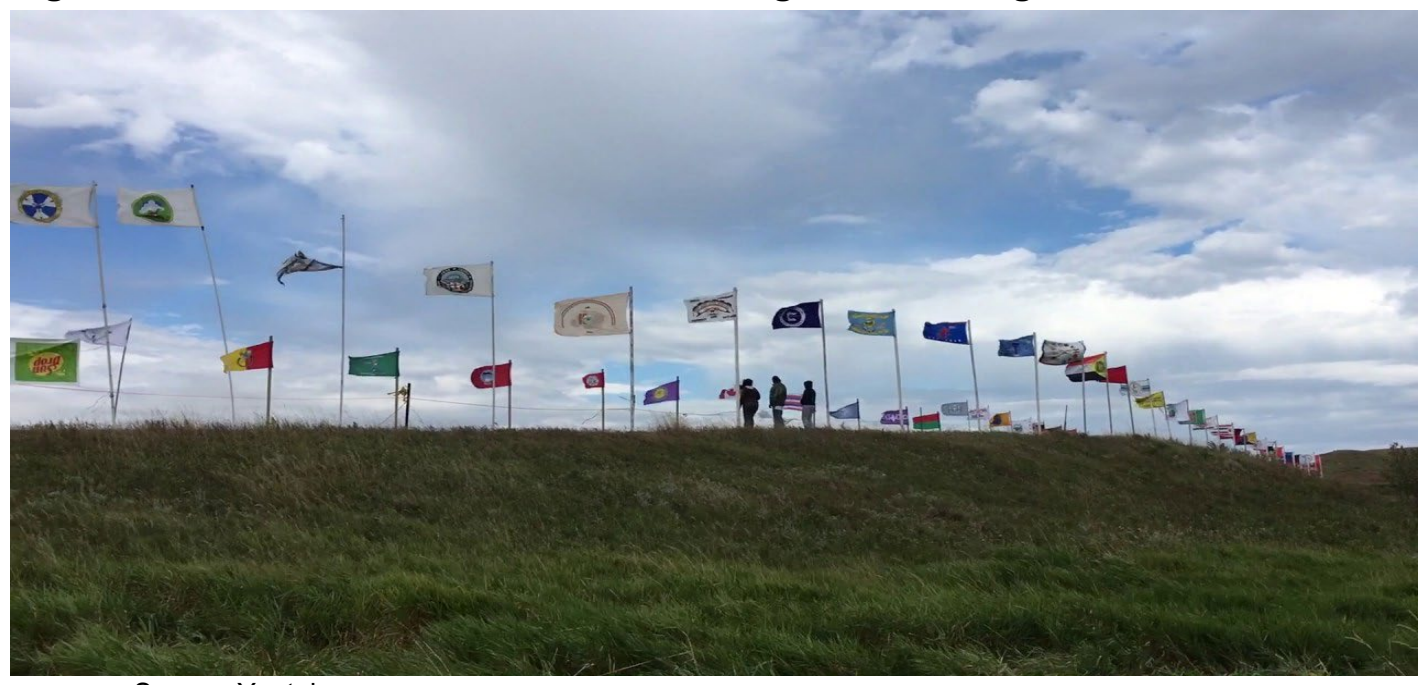

Source: Youtube

This is not the only time the Miccosukee members have reached out to help those in need. After Hurricane Harvey hit Texas in August 2017, Betty Osceola, helped fund a group of volunteers referred to as the 'Florida Navy' who travelled to Texas to help victims trapped by the flood waters. She additionally collected donations of food, clothing and other items and delivered them to Louisiana in the 2016 flooding. The Miccosukee tribe allows members to set up collection points in the Miccosukee Resort and Gaming and in their tribal office which donated linens for them to take. Betty was later interviewed multiple times regarding the Miccosukee experience of predicting and surviving hurricanes in South Florida (Sainato, 2017).

The Miccosukee and Seminole tribes are very conscious of the need for sustainability in economic development. The Miccosukee are much more engaged in ecological efforts, but they have a diversity of economic development 
among the few business enterprises that they have. The income generated is not as abundant as from the Seminole enterprises, but they are much smaller in number and much more remote, albeit by choice. The Miccosukee might be able to invest more in their economic development, if they were not constantly litigating to maintain ecological safety for themselves and others affected by the harsh treatment of the Everglades.

\section{Summary}

Chapter 4 discussed the joint beginnings of the Seminole and the Miccosukee, as well as the various reasons behind the need for distinction from each other as they set up their constitutional existence and their relationship with the US Federal Government. Following their establishment as two diverse tribal entities, current activity reflects better the priorities of the two governments in developing and implementing policy. The Seminole Tribe are more willing to work with state agencies seen as minimalizing water quality or have a willingness to accept Florida agencies' expert opinion. The Miccosukee, unyielding in their insistence that the opinion of their expert and of Ron Jones of FIU prevail, have preserved the health of the Everglades ecosystem, which they believe is more important than appeasing state officials.

Chapter 5 presents the economic development started by the Seminole and Miccosukee governments. Sustainable economic development priorities for each tribe are based on conversations with tribal members and the development trends that have evolved thus far. Documented interviews with early leaders 
assist in understanding the struggles experienced by tribe members and leaders in the course of development of various types of commerce. 
CHAPTER 5. SUSTAINABLE ECONOMIC DEVELOPMENT PRIORITIES

\section{Introduction}

The priorities of the Seminole Tribe of Florida and Miccosukee Tribe of Indians of Florida is the focus of this chapter. Issues were grouped together after examining interviews for recurring topics. This resulted in the top three issues by count, deciding the importance by frequency. Unlike the extant literature (e.g., Cattelino, 2008), I show that the casinos are but one factor of their economic development and that their development is sustainable for more reasons than casino revenue.

The economic development priorities of the Seminoles and the Miccosukee are similar in several aspects, but there are a few key differences as well. Sovereignty and education are the two main concerns for both tribes. However, while economic independence is a major concern for the Seminoles, the Miccosukee place significant value on their ecological environment.

The priority for both the Seminole and Miccosukee Tribes center around a sharing of history and culture. Much like the ties between cultural integrity and economic development (Smith, 2000, p. 367), economic development can promote education or learning in many areas. The terms used most often centered around teaching and learning, as in educating people about tribal uniqueness and history. There is a desire to share history as an inclusive story, viewed in an alternative perspective to the Eurocentric outlook common to U.S. society. The Seminole and Miccosukee Tribes encourage tribal members to 
know their rich histories. They pass knowledge between themselves traditionally, through verbal communication and storytelling. Preservation through libraries and museums gives opportunities for the non-indigenous to learn about Seminole and Miccosukee histories and culture in a way familiar to them. People not engaged with tribal members, who believe that Indians should assimilate into mainstream society, would be able to better understand the significance of the Native American tribes through these shared cultural experiences. What some see as the preservation of their culture and history are educational experiences in various forms by tribal members. As S17 stated, "Education feeds the economic development, in turn, economic development feeds education".

The second priority for the Seminole Tribe is independence. Though the term "independence" comes up multiple times during several interviews, the term mainly implies control over their own governance. For example, they seek control over their own businesses and control over their destiny, rather than other governments, businesses, or organizations exercising a form of control, which affects the Seminole Tribe in some form or the other. For the Miccosukee Tribe, the environment and the impacts on the environment and therefore their people, was the second priority. The third priority of both the Seminole and Miccosukee tribes is sovereignty. Respect and recognition as a separate people with a separate government caring for their people best describes the sovereignty context. The conventional understanding of sovereignty still stands: law suits against the tribal government or the U.S. government cannot occur without their 
consent, and one level of government cannot charge another level of government any tax.

The Miccosukee tribal members originally chose not to be part of the Seminole Tribe of Florida when they sought recognition due to political differences. Political differences surfaced in a reluctance to accept the settlement by the Indian Claims commission for payment for Florida land taken by the U.S. military. Seminole members are also less private than the Miccosukee members, placing more tension in the solidarity between the two tribes. Whereas the Seminole members may be comfortable with sharing cultural information with outsiders, Miccosukee may not be as comfortable sharing such information with outsiders. The U.S. government set up a payment for land taken from the Seminole and Miccosukee members, which was to be divided between the Seminole Tribe of Florida, the Seminole Tribe of Oklahoma, and the Miccosukee Tribe of Indians of Florida; however, the Miccosukee Tribe of Indians of Florida never accepted the payment. Indeed, the Miccosukee buckskin declaration highlighted that they didn't want the money, they wanted their land. Many of the members said that the land is more valuable than any amount of money they could receive.

\subsection{Economic Development Priorities of the Seminole Tribe}

\section{Cultural and Historical Sharing}

Indian tribes generally confer with one another through pow-wows, which are cultural settings for the tribes to share their rich heritage. In the case of the Seminole Tribe of Florida pow-wow, it is an opportunity to share and compete in 
traditional dance (ceremony) for prize money. There is a pow-wow circuit which travels, much like the rodeo, around the country with different events at various times of the year and at many locations. In February 2018, the Seminole powwow attracted hundreds of families from across the United States and Canada to the competition. Many of them drove to the Seminole Big Cypress reservation and stayed at the various camp grounds provided by the Seminole Tribe of Florida. Whole families, including babies to grandparents, enjoyed the adventure and camaraderie of the pow-wow. The various dances even included little tots and children showing their cultural skills in traditional dance as they circle around the arena. The competitions had various forms of dance in cultural regalia for prize money. The men's dances include Straight (Hethuska) dancing, Chicken dancing, Fancy Feather dancing, Grass dancing, and Northern Traditional dancing. The men also compete with drum groups. Age groups delineate competitive groups as follows; Golden age is $55+$, Senior is $36-55$, and Junior is 18-35. Women have the same age breakout, but compete in Fancy dancing, Jingle dancing, Northern Cloth dancing, Southern Cloth dancing, Northern Buckskin dancing, and Southern Buckskin dancing. Teen boys and teen girls compete with one another as well and there was also a sweetheart special dance where couples competed against one another doing their preferred dance. The 2018 dance competitions have prizes ranging from $\$ 1200$ for $1^{\text {st }}$ place to $\$ 600$ for $4^{\text {th }}$ place. The 2018 drum competition ranged from $\$ 20,000$ for $1^{\text {st }}$ place to $\$ 2,000$ for $7^{\text {th }}$ place, with another three consolation prizes. These prizes show the importance placed on cultural knowledge and skills. The Seminole withhold taxes 
for U.S. registered tribal members winning prize money. Canadian members receive checks in full. Not all pow-wows have prize money for competition; there is, however, traditional dance and drums, sometimes in demonstration and always in ceremony with others. The flyer and photographs below are from the 2018 Seminole Tribe of Florida Pow-Wow. Figure 5.1 depicts a photo taken during the Grand Entry which allowed those competing to enter the arena displaying their regalia and the various dancing styles. Figure 5.2 is a photo of one of the drum groups that was competing, and Figure 5.3 is the flyer which also appeared as billboards in various locations around Broward County. This type of ceremonial participation and dancing acts as a sustaining, rather than restorative activity as observed in the Amazon by Plotkin (Plotkin, 1993).

Cultural tourism is another longstanding enterprise that continues to grow and evolve. The Seminole Tribe promotes tourism tied directly to their reservation and accommodations but also has developed the Native American Travel (N.A.T.) The agency can book international and domestic travel at negotiated rates for both air travel and cruises. 
Figures 5.1-5.3 Seminole Pow-wow activities and flyer, 2018
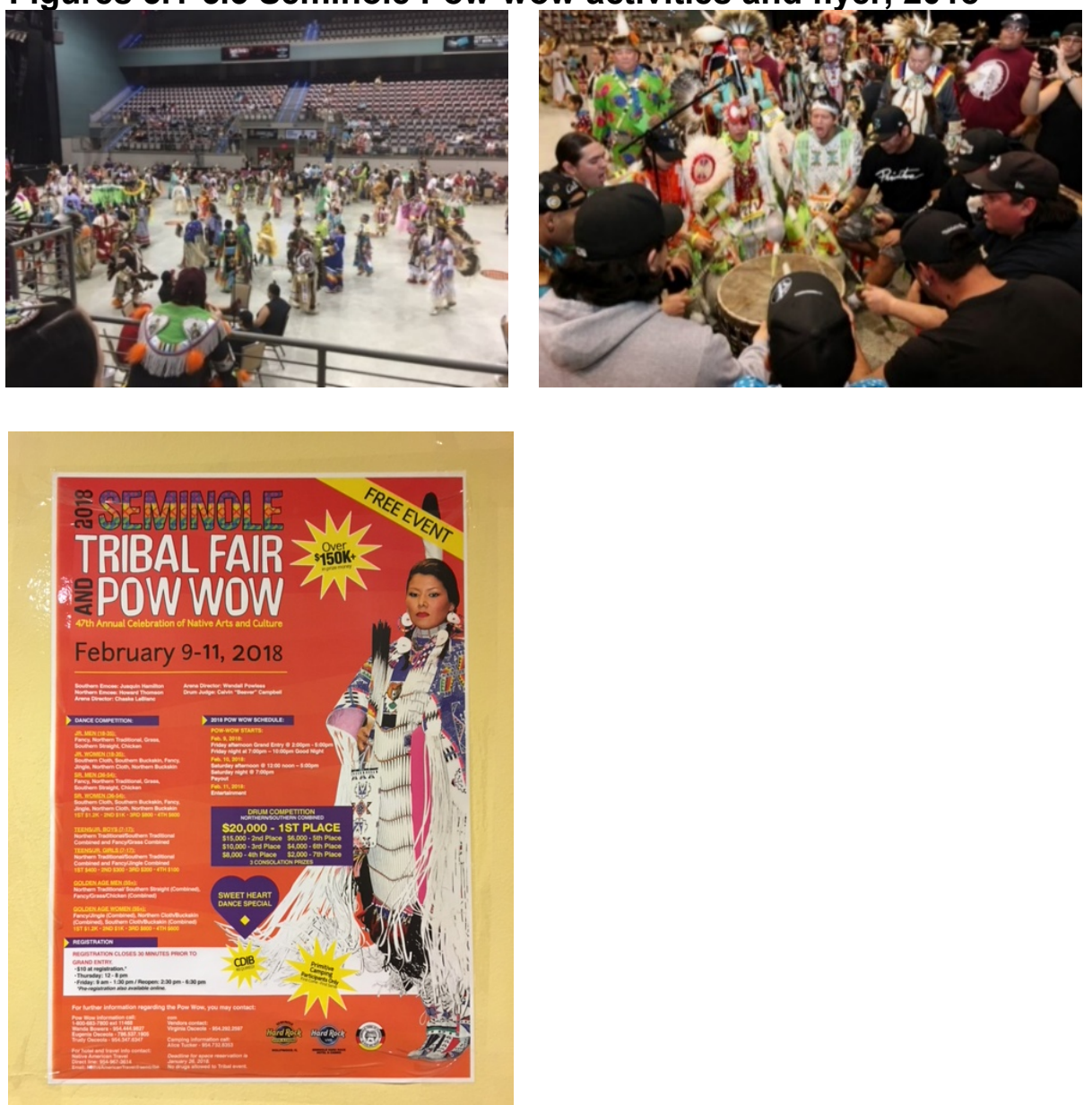

Source: Author (photo of flyer above - flyer created by Seminole Tribe

\section{Sports}

The use of cultural activities and sports as an economic development tool and means for conflict resolution has been emphasized in scholarly research. Sports can be used as a team building exercise and for constructing a sense of solidarity or a sense of family and to build harmony (Zhao \& Roper, 2011). Teamwork helps develop group skills through games like basketball. Anticipation skills, for example, have shown to become keen with basketball. Some critics, 
however, have argued that sports promote individual achievement, are susceptible to the neo-liberal development image, and are likely to be unsustainable. In economic policy terms, neo-liberalism results in the rich becoming richer while the poor become poorer. This criticism does not recognize the individual achievement used to reach a team goal. Sports can indeed challenge the ideology of individual achievement through team sports (Darnell, 2010).

Rezball, which is another name for basketball played among Indian tribes from different reservations, has become a popular sport. Teams of players from different reservations compete against one another. This competition also offers prizes. There are different age brackets for male teams, female teams, and mixed male/female teams which are generally played from Thursday through Saturday the week of the tournament. The teams compete through multiple rounds until one team from each bracket stands. Competition consists of grueling 16-hour days of dynamic play by these teams. The team names sometimes stand for their general location, like "Plainsmen", or clan names, like "Big Town". The competition is intense, and the players' endurance is impressive. Time after time the same team would play, resulting in the elimination of another team. The courts at the Hollywood reservation are also impressive, rivaling any modern college or community center. The Native American Basketball Invitational (NABI) supports Rezball and has appeared in newspaper articles and on ESPN. Nike has also designed a basketball shoe specifically for Native American players (Colorlines, 2013). Since the first Nike design, Kevin Durant, a U.S. professional 
basketball player, has collaborated with Nike on various shoe designs to support Native American youth (Nike, 2013). Collaboration between large and small firms, according to research, creates interdependence or symbiotic relationship building, bringing benefit to both firms (Etemad, Wright, \& Dana, 2001). In addition to recognition by college recruiters, the NBA, and athletic apparel icons like Nike, other businesses have also begun to cater to Rezball. RezBall Affiliate, for instance, which designs and produces uniforms and active wear, uses Native American symbolism and colors. Attendees and participants at the Seminole Tribal competition were wearing assorted items with the RezBall Affiliate logo 㑩. The designs are unique and eye-catching. In addition to teams buying uniforms to play in, fans also show unity by wearing their teams' colors. RezBall Affiliate has been growing over the years, which is a good instance of Rezball's impact as an economic multiplier. Youth sports and supporting industries are a multi-billion-dollar industry with an upward trend, including uniform manufacturing and sports tourism, according to a recent University of Florida Study ("UF Economy of Youth Sports," 2015). Figure 5.4 shows Native American designs used in the sports. 
Figures 5.4 Rezball Affiliate designs
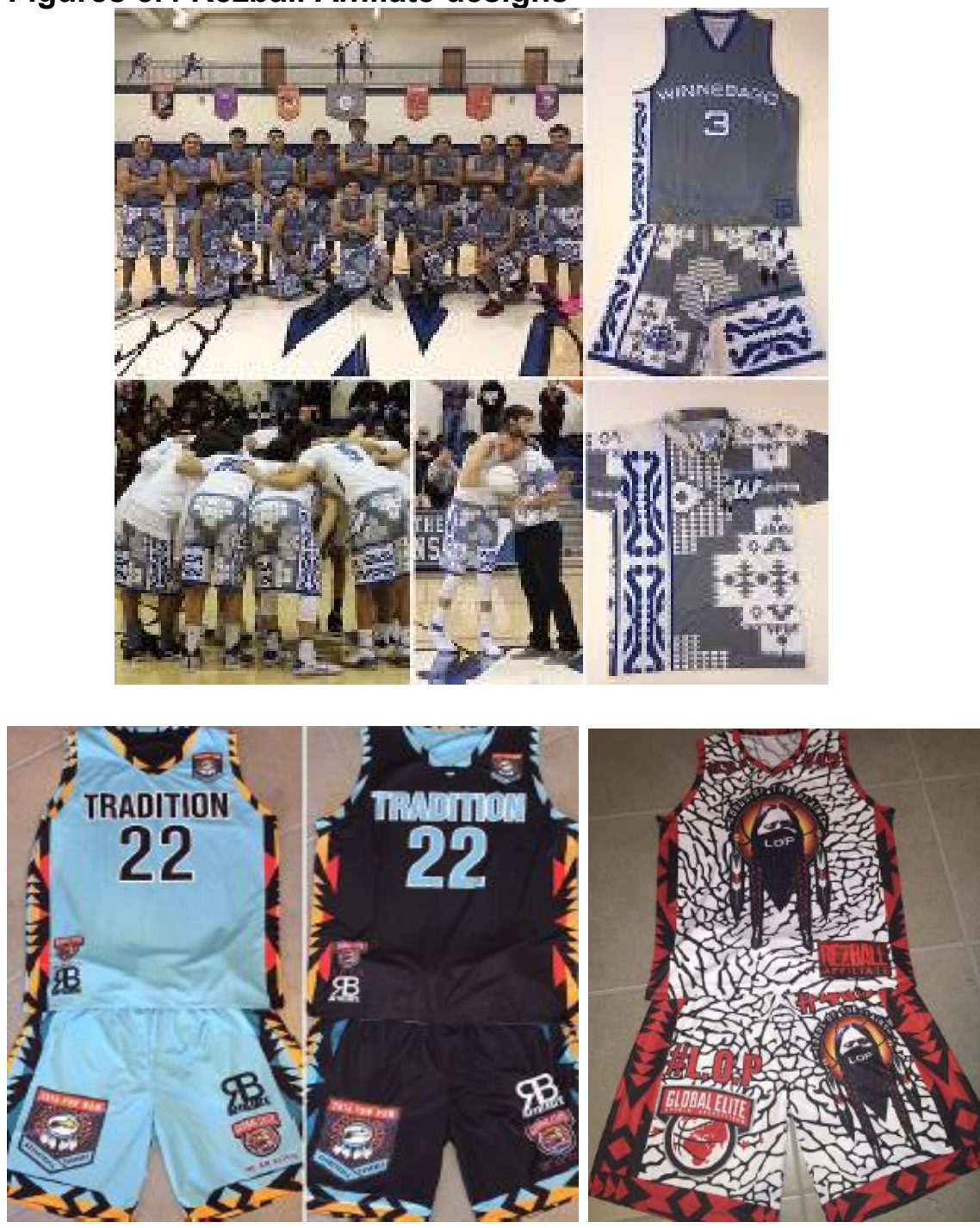

Source: Rezball Affiliate

The Seminoles hold the Rezball competition annually as an inter-tribal activity. The Pow-wow and tribal fair occur the weekend after the RezBall tournament. The tribal committee has invited students from both Miami-Dade college and Florida International University, to help in the efforts for the past two years. The Rezball competition takes place at the Seminole Tribe of Florida's 
Howard Tiger Recreation Center, built by Seminole Board Construction LLC. The center houses two large basketball courts that break down into smaller half courts for the youngest competitors. The same recreation center houses the boys \& girls club, a fitness center, and other teaching rooms. A room labeled cultural center holds sewing machines used in learning the Seminole patchwork used on traditional clothing. There are also display cases with photos and awards on the main floor. Various buildings owned by the Seminole Tribe of Florida display this type of memorabilia. This expression of accomplishments continues to promote pride in the heritage and reminds members of their history. Figures 5.5 to 5.7 below display the facilities. Figure 5.5 shows the exterior of the building while Figure 5.6 and 5.7 show the basketball courts. The recreation center is modern and carries the traditional colors of red, black, yellow, and white. The building has all the amenities one would expect to find in expensive health clubs found off the reservation. A manned guard house and gate ensure secure entrance to the grounds. Several students who helped with Rezball scoring and t-shirt sales commented how they had not expected the facilities to be as modern and contemporary, while some mentioned the resemblance to military installations.

Figures 5.5-5.7 Seminole Recreation Facility in Hollywood

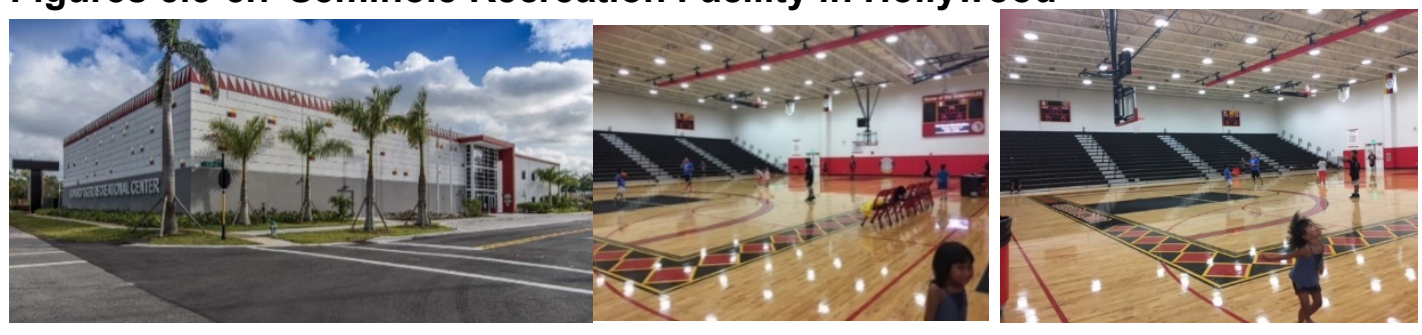

Source: Author 
Other historical events celebrated by the Seminoles includes the dedication of the Big Cypress Tribal Oak. The Ah-Tah-Thi-Ki Museum conducts these dedications at the various Seminole reservations to preserve historical markings such as the Tribal Oak at Big Cypress reservation and the Red Barn at the Brighton reservation, both of which are landmarks where tribal members met to decide how their constitution would develop, as they prepared for federal recognition. These landmarks serve to remind members and teach others who the Seminole Tribe are as a people and continue to reinforce their resolve as a tribe. The Tribal Oak is an oak tree found on the Big Cypress reservation. The address where it stands is 30901 Josie Billie Highway, shown as the Frank Billie historic camp on various maps. Frank Billie served as the first President of the Board of Directors for the Seminole Tribe of Florida Inc. (Seminole Tribune, n.d.). Events are often open to the public, allowing anyone who wishes to learn about the tribal history and to take part. This specific oak tree served as the meeting place for the members of the Big Cypress reservation community, to discuss issues of importance. The stories shared about early entrepreneurship with members setting up across the street from the oak tree with gasoline cans for travelers going across the state of Florida were fascinating. They spoke about travelers having few choices for driving from coast to coast across South Florida. They knew that people would travel Alligator Alley, which at the time was a twolane highway going right through Big Cypress Preserve where some Seminole Tribe members live. They laughed as they reminisced about taking shifts with one another, waiting for travelers to realize that they needed gasoline, then 
discovering that there were no official gas stations nearby. When the travelers would stop to ask where to buy gasoline from the tribal members, gasoline stored in gas cans was available. The members would also offer fruit, water, soft drinks, and many other items, including souvenirs. They shared stories highlighting their entrepreneurial spirit. They would be hot and uncomfortable, with the sun beating down on them, but knowing that someone had to "make sure that folks made it across the state", and laughter would erupt. They did not have the casinos then and times were hard, but they had spirit, their knowledge, and their land. After the dedication, the museum invited everyone to the nearby gymnasium for lunch, again open to the public and offered free of charge. Upon arrival, the Ah-Tah-Thiki museum offered a booklet of pictures available to everyone. The booklet carried several pictures of tribal members during the time that the meetings under the tribal oak took place. 
Figures 5.8-5.10 Graphics provided by the Ah-Tah-Thi-Ki Museum for the installment of memorial
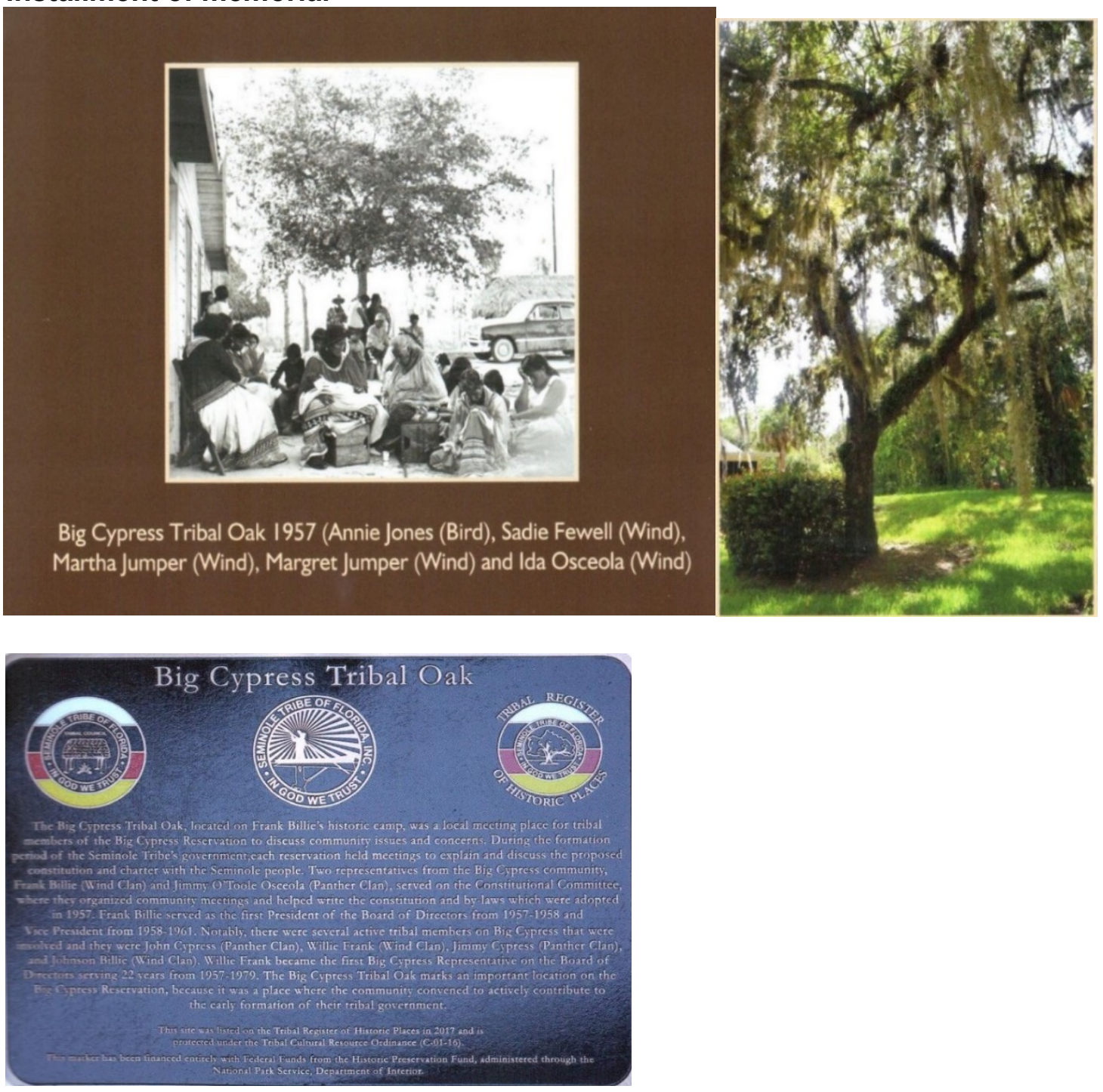

I watched one such dedication where the members named their relatives in the pictures. Interviewee S17 said she misnamed one of her family members when speaking at the museum, another tribal member, an elder, corrected her, telling her who the person in the photo really was. The interviewee thought that the member in the photo was a cousin, only to learn later that it was her uncle. Members found uncles and cousins, and laughter would ring out as "Oh you're 
right" resonated. The experience was like attending someone's family reunion and hearing all the conversations declaring their memories to one another. It was such an uplifting experience to share in this event with the tribal members. Figures 5.8-5.10 are a few of the photos from the event. Interviewee S6 is an activist who often travels to Washington D.C. with a motorcycle group advocating for recognition of tribal sovereignty. Interestingly, she shared that she finds the name Seminole Tribe of Florida a bit offensive, since this was a name given by non-native people. Believed to be a Creek word for renegade or wild, or a mispronunciation of the Spanish cimarrones (runaway), Creek was also what the non-native people called those who had made their villages along the Ocmulgee Creeks of Georgia. Upon creating their constitution, the Seminole Tribe of Florida chose this designation. There is a forced acceptance of colonization, to meet the criteria. In seeking recognition, a tribe must prove their existence prior to colonial settlement. Since tribal records were not in English, nor written, acceptable records of existence only occur when recorded by non-native entities using their European norms and language. The Brighton reservation had a similar meeting place called the Red Barn. The Red Barn in Brighton (Figure 5.11) is also where the cattle enterprise for the Seminole Tribe had its meetings about their constitutional beginnings. Figure 5.12 shows the marker chosen for the Red Barn. 
Figures 5.11-5.12 Photos taken at the Red Barn at the Brighton Reservation
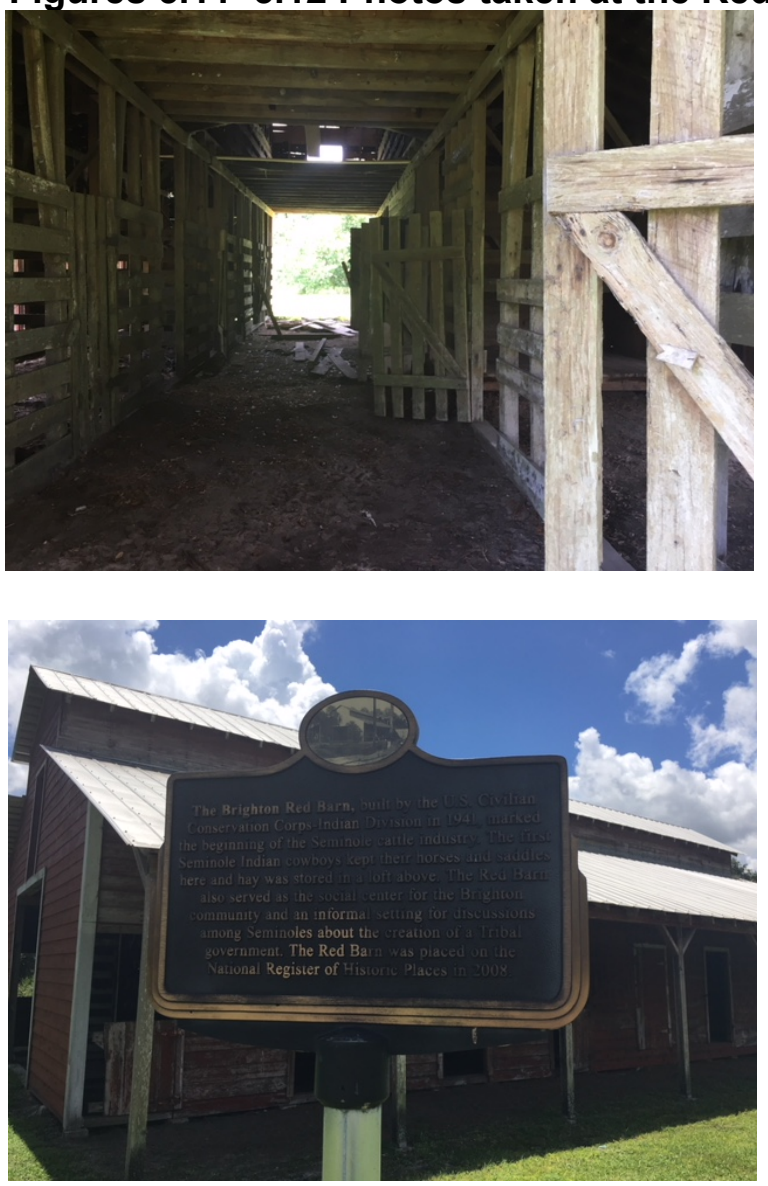

The events which show permanent landmarks in Seminole Tribe history and on Seminole tribal land are through the efforts of the Ah-Tah-Thi-Ki Museum. One of the first ground breakings that the Seminole Tribe had was that of the museum. The name Ah-Tah-Thi-Ki means "a place to learn" or "a place to remember". Developing the museum and collecting their history ensures preservation and a shared history throughout the future. They also wanted to share their history with non-natives who may find museums easier to relate to. "Native Americans have been eliminated" or "Indians do not exist" is a painful comment to hear. For anyone to hear that they no longer exist implies that they 
are irrelevant or forgotten. Seminole and Miccosukee members spoke of hearing these things. The invisibility of entire populations can explain why the topic of ensuring that people knew they are not gone appeared often. Figure 5.13 is a photograph of the Ah-Tah-Thi-ki Museum ground breaking.

\section{Figure 5.13 Photo provided by Ah-Tah-Thi-Ki Museum}

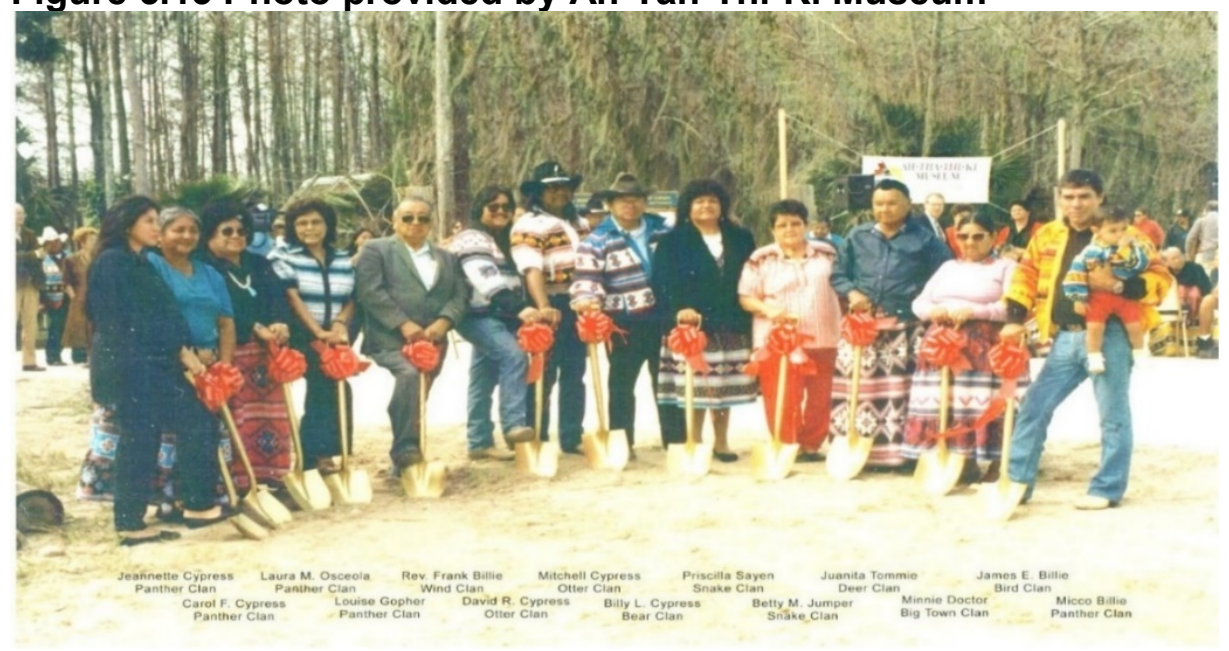

The Ah-Tah-Thi-Ki Museum celebrated their $20^{\text {th }}$ anniversary during this research, another opportunity to learn from tribal members and for the public to attend. The photo below (Figure 5.14) shows myself, my good friend, my daughter, and the Seminole Tribe of Florida member dressed in traditional clothing. The metal plates on the Seminole member's chest are three shiny plates in vertical alignment. Traditional regalia now incorporates these plates which Spanish travelers originally gave to the Seminole. Each plate has clan and personal identification symbols pressed into them, which look to be composed of silver. He also wears traditional beads which hang around the plates. 
Figure 5.14 Photo taken at Ah-Tah-Thi-Ki Museum anniversary celebration

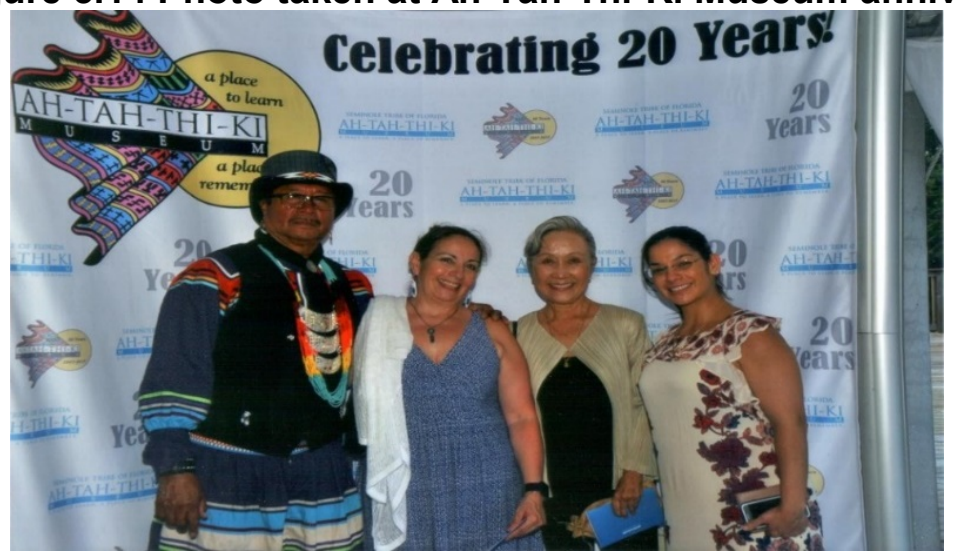

\section{Seminole Tribal Sustainability}

The Seminole Tribe of Florida has both a natural resource director and an economic development director. Interviewee S2 said, "We've always been sustainable, you never take from the land more than the land has to offer". This is a common Native American conviction, that the Creator gives the resources you need but no one should take more than needed. The Seminole Tribe cattle program, one of the oldest tribal operations, is a leader in the cattle industry. The tribal operation perfected the sale of cattle by using video auctions, electronic animal identification, and creating the 'Seminole Pride' brand. In 2008, the Seminole Tribe of Florida, under a U.S. Department of Interior joint venture, considered collaborating with other Native American tribal beef production organizations. This venture included the Native American meat processing company in Wichita, Kansas and a Midwest meat company. The president of the Midwest meat company, a Sioux nation member (name unknown), may explain the inclusion in this collaboration. The plan was to have cattle raised, processed, and packaged with the Seminole Tribe of Florida Logo (STOF) stamped on it, 
which the organization would distribute to hotel chains, U.S. military bases, retail outlets, and tribal casinos and restaurants. The business plan called for beef distribution using the West Palm Beach based Cheney Brothers company. Interviewee S2 said that under these types of agreements, it is particularly difficult to ensure standards. He spoke about Publix supermarket, a southeast U.S. grocery chain, requesting to sell Seminole Beef, but the current production level could not meet such a demand. Since there is not enough reservation grazing land, expanding the Seminole beef production to meet this type of demand requires alternative solutions. The joint venture with the Department of Interior would allow them to meet such demands but has created concerns about independence and decision-making control. Due to apprehensions about compromising the quality standards of Seminole Pride Beef, they have remained a local producer, choosing instead to cooperate with local farmers rather than collaborate with the Department of Interior. The cooperative with local farmers allows the Seminole Pride products to remain under Seminole Tribe control, maintaining their standards while expanding the production and profitability, and helping both local farmers and the Seminole Tribe of Florida. They have plans to expand next into Georgia, co-opting local independent cattle ranches there.

Seminole Pride ${ }^{\mathrm{TM}}$ Beef is a natural lead into another traditionally maintained organization, the Seminole Tribe of Florida Rodeo. The rodeo, with all their competitions and demonstrations, runs the same weekend as RezBall, just prior to the tribal fair. Culturally, this too is a maintenance of skills not lost within the Seminole Tribe. 
Contrary to the myth perpetuated by early Hollywood Westerns, the original "cowboy" was in fact the Native American. Florida has the distinction of having the first American cowboys, known as the "Cracker Cowboys". The Seminole Tribe of Florida speaks of this history in the Seminole Tribune (Soler, 2013, para. 1), and Tom Correa, a former marine and western history blogger also offers historical accounts (American cowboy chronicles, n.d.). The Seminole Tribe of Florida has held demonstrations of a "cracker", which is a cowboy using a whip to make a cracking noise, during the tribal festivals. These demonstrations are part of the visit to the historic village. The Ah-Tah-Thi-Ki museum supports the village located near the museum. The demonstrating cowboy gives you the opportunity to stand in place while he wraps the whip around your legs, or waist, generating the sound of a snap (the crack) as the whip completes its journey. The cracking sounds as if there should be pain, but there really is none. There is sound, but no physical discomfort. What looks like a painful way of moving the cattle to where you want them turns out to be comparable to slapping a newspaper on your hand when disciplining a dog, it is more about the sound.

The Seminole Tribe of Florida owns several brands run by the Seminole Tribe of Florida, Inc. Seminole Petroleum is a petroleum distributor with bulk plants and transportation fleets distributing both fuel and lubricant to various businesses throughout Florida. While visiting Brighton reservation, this truck was outside the convenience store (Figure 5.15), in an area of the reservation where they have the Brighton RV resort and four cabins that they rent, promoting 
cultural tourism. There are 25 acres with 56 campsites including water, electric, and sewer hookups. The convenience store is open 24 hours a day and there is a swimming pool and laundry facility available.

\section{Figure 5.15 Seminole Brighton Reservation}

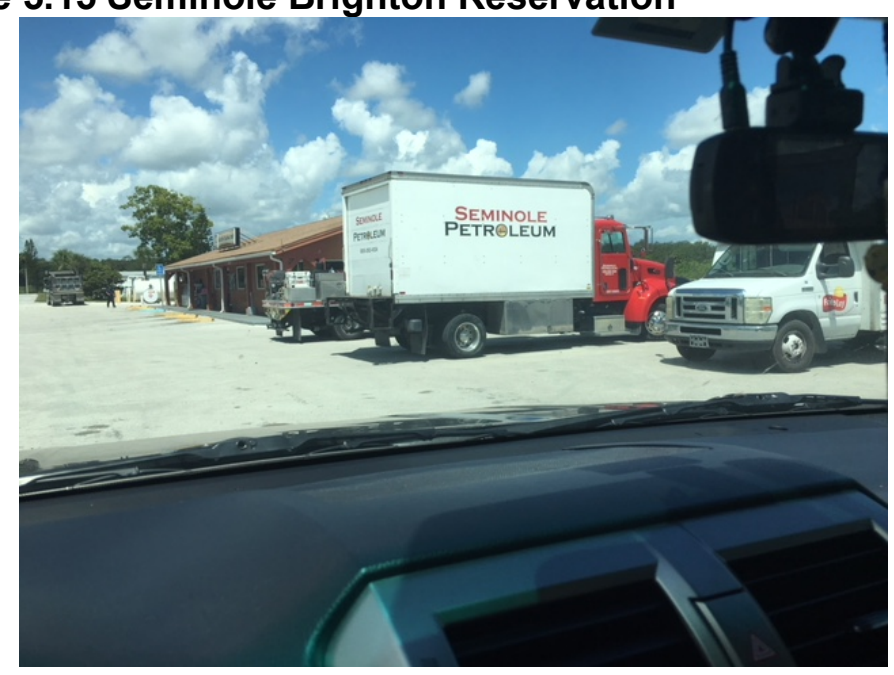

Inside the Brighton reservation convenience store, employees were a bit guarded. Eventually they shared that they are related to each other by marriage and do not live on the reservation. The Seminole Tribe of Florida restricts reservation residency to members with a minimum one quarter (1/4) Seminole blood quantum. This is a measure taken to ensure sustainability of the reservation. The Seminole Tribe of Florida Constitution, ratified in 1957, says, "any person of Seminole Indian blood, whose name appears on the Census Roll of the Seminole Agency of January 1, 1957, shall be eligible for enrollment, regardless of blood quantum or place of residence". This has not changed, the tribe enrolls the children as tribal members, but the children do not live on the reservation. The children are family and know their heritage and share in the 
culture. The reservation is a preserved fixed commodity, so there is a limit to the use. Living off the reservation is not unusual either. Interviewee S15 is blood quantum qualified to live on the reservation and told me, "My family has never lived on the res, it was not something unusual. It was always felt that the government wanted to hold you there or trick you. So, they just never went but we stay close, and we attend ceremony". S15 was referring to the annual gathering for the Green Corn Dance, a private ceremony for both the Seminole Tribe of Florida and the Miccosukee Tribe of Indians of Florida.

Seminole Pride ${ }^{\mathrm{TM}}$ Premium Fresh Fruit grows through sustainable agricultural practices following Seminole Tribe of Florida tradition. They preserve the ecological system while producing Naturally Native ${ }^{\mathrm{TM}}$ products. The trademark, Seminole Pride ${ }^{\mathrm{TM}}$, comes after a partnership with the Noble company that marketed orange juice under the Seminole brand. Interviewee S2 explained that, just as with the beef, working with other companies sometimes restricts the amount of control and partners sometimes do not meet the standards that the Seminole brand wants to keep. While attending the Sacred Oak dedication, the museum provided bottled water labeled with the Seminole name (Figure 5.16). The OWV water is naturally alkaline spring water sourced from Orange Springs Florida, found near Ocala National Forest. OWV water, pronounced "ooh-wah" in the Seminole language, reinforces the preservation of land and water in Florida, again showing traditional values. In addition, OWV water has been certified Kosher, showing concern and cultural sensitivity toward the beliefs that others have. 


\section{Figure 5.16 Photo of Seminole Brand Water}
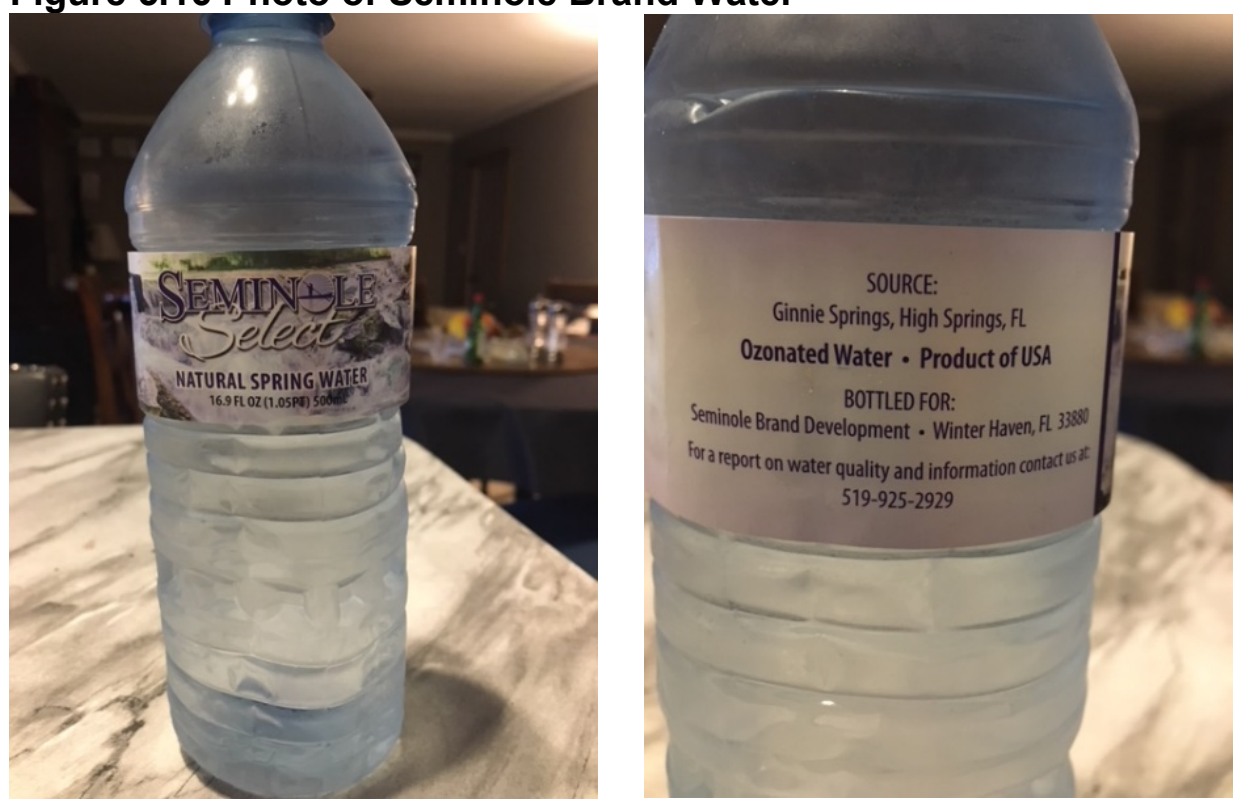

Another well-established Seminole Tribe of Florida enterprise is the Brighton Mining Operation. They excavate and process material from mines, selling several products to the public either as construction grade or as department of transportation (DOT) approved products like fill dirt, shell rock base or cobblestone rocks used to build roads, pads for houses, etc. This is a long-standing enterprise.

As the Seminole Tribe of Florida has continued to set up and build enterprises much like non-reservation businesses. When the Seminole Tribe of Florida decides that they need or can offer a service or product, they think competitively. They decide on the feasibility of creating their own company to competitively provide the service. The auto industry is an example. Auto company subsidiaries create parts needed for assembly of the auto. General 
Motors Corp. in 1999 spun off the Delphi parts company. Likewise, the Seminole Commercial Cleaning and Maintenance Services of Florida started Jani-King as a commercial cleaning and maintenance service company. Jani-King started in 2012 to offer customers nearby and on the various reservations commercial cleaning services. Executives of Seminole Commercial Cleaning and Maintenance Services of Florida (SCCMSF) manage Jani-King.

One of the unique new ventures of the Seminole Tribe is an Asian-cuisine restaurant featuring Vietnamese and Chinese dishes, named The BOL. They boast of Feng Shui principles in the design of the restaurants. Feng Shui is a Chinese method of spatial arrangement and orientation that attracts positive energies while keeping negativities at bay. There are two of these new restaurants. One restaurant is in the Seminole Hard Rock Hollywood casino near the main entrance and the other is at the Seminole Casino Coconut Creek, the original bingo hall.

The largest enterprise for the Seminole Tribe of Florida, which garnered the most publicity, was the near one billion-dollar (\$965 million) purchase of Hard Rock International in 2006. At the time, Max B. Osceola Jr. said, "Our ancestors sold Manhattan for trinkets. We're going to buy Manhattan back one burger at a time" (De la Merced, 2006, para. 3). Financing of Hard Rock International is through equity from the tribe and through debt under an operating company which controls Hard Rock. Some people quickly assumed that the Seminole Tribe of Florida was extremely wealthy, having taken on this purchase. However, the methodical and pragmatic steps taken both before and after assuming this 
massive debt exposes the sustainability of the Seminole Tribe of Florida. They do not spend money wildly; they account for any spending, much like any corporate entity would. The Seminole Tribe of Florida is very measured in how they plot steps to advance their economic development.

Thanks to the efforts of the Seminole Tribe of Florida, all Native American tribal people can develop casinos on tribal land, though this may not be practical for isolated reservations. Following the landmark win against the state of Florida, and the establishment of the Indian Gaming Regulatory Act of 1988, a compact has developed between the state of Florida and the Seminole Tribe of Florida. Governments, unable to tax tribal governments, receive casino revenue through compacts. Only if the state allows prohibited games, exclusively on tribal land, are compacts developed.

Though they already owned the casinos in Hollywood and Tampa before 2004, in 2004 the Seminole Tribe of Florida licensed the Hard Rock name for those two casino hotels. By 2006 the two locations were generating $30 \%$ of Hard Rock International's total profits through these licensing deals alone. When Rank Group, the Hard Rock licenser, put their complete collection of Hard Rock Hotels and Casinos up for sale, the Seminole Tribe of Florida made the purchase of the Hard Rock International chain which included 124 restaurants, 7 hotels, 2 casinos and 2 concert venues in 45 countries. In 2016 the Seminole Tribe of Florida bought the remaining rights of the Hard Rock Hotel and Casino brand, taking over global ownership. From a licensing deal to the ownership of the entire brand and properties internationally is impressive. 2016 marked the first time in 
over 35 years that the Hard Rock Brand had been under one owner. As of 2016, Seminole Hard Rock owned or licensed 168 cafes, 23 hotels, 11 casinos, and 5 concert venues, with a presence in 68 countries. The original two casinos, in Hollywood and Tampa Florida, are among the top five most profitable casinos in the country, with Tampa being number one. As of 2016 there were another 25 Hard Rock hotels planned, and they also bought Hard Rock Las Vegas and all licenses held by BREF HR, LLC. In 2006 when they bought Hard Rock International, the Las Vegas property was not part of the purchase, because Morgans Hotel Group bought it for $\$ 770$ million. With the 2016 total ownership rights, they took control of the Las Vegas property and locations in Lake Tahoe, Nevada, Sioux City, lowa, Tulsa, Oklahoma, and Vancouver, Canada. The Hollywood Hard Rock location is under heavy development now, building an iconic hotel designed in the shape of a standing guitar. 
Figures 5.17-5.20 Construction of Hard Rock Hollywood
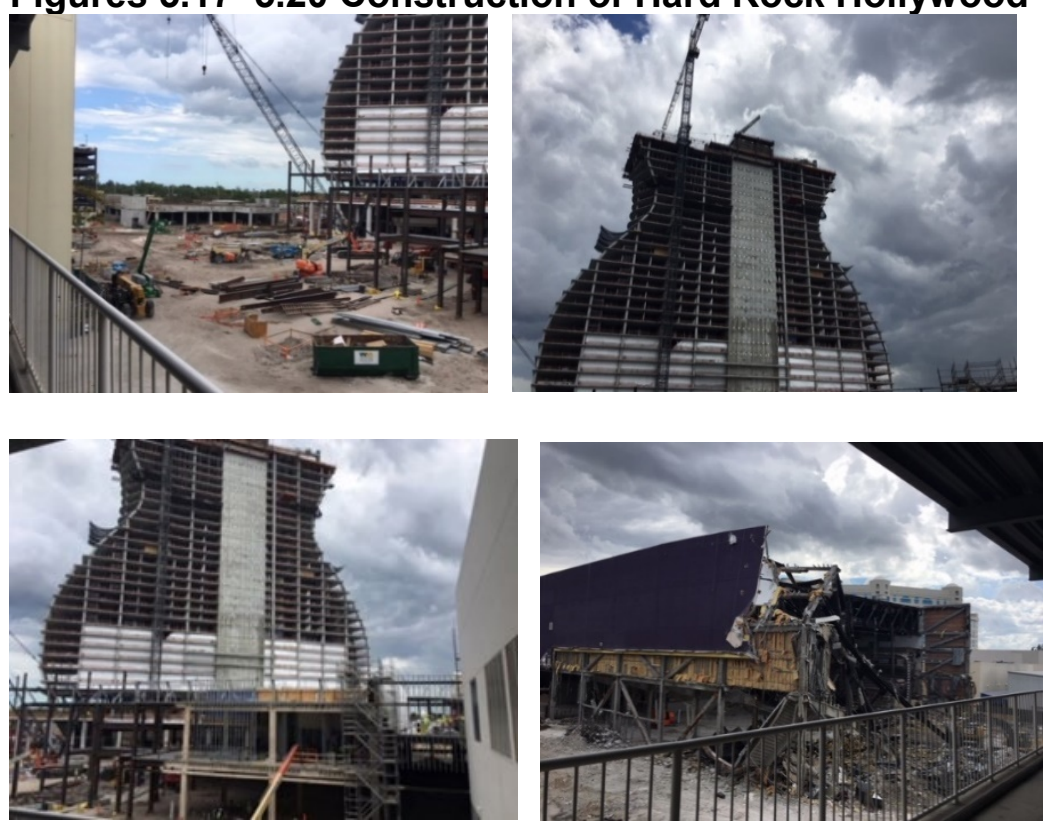

The ability to grow in a market that has challenged many similar organizations also speaks about the sustainability of the Seminole Tribe of Florida. In efforts to continue the growth of Hard Rock International, on March 1, 2017 the Seminole Tribe of Florida announced their expansion activities. They are the majority owner in a partnership with the Morris and Jigoli families in forming an investment group. Together they bought the boarded up former Trump Taj Mahal from billionaire Carl Icahn in Atlantic City New Jersey. Icahn closed it four months prior to that amid a crippling strike. The investment group said that they would be investing over $\$ 300$ million in the renovation and reopening of the casino. As of May 3, 2018, the investment group has installed the slot machines, and removed all the Taj Mahal inspired decorations. The iconic Hard Rock oversized guitar entrance and music memorabilia scattered 
around the casino updates the look (Figure 5.17). They announced on May $3^{\text {rd }}$, 2018 that they had just hired their $3,000^{\text {th }}$ employee and were looking to hire another 3,500 before opening in June 2018. The newest of the Hard Rock International hotels has received over 20,000 applications, so finding the right 3,500 should not be too difficult (Rosica, 2017; Parry, 2018).

Things move constantly and fast where Hard Rock International is concerned. On March 31, 2018, Richard Branson, Virgin Group founder, bought the Hard Rock Hotel \& Casino in Las Vegas. Virgin Hotels Las Vegas will be the new name, but it will remain Hard Rock until the renovation is complete, expected at the end of 2019 .

To continue building name recognition, the Hard Rock licensed the branding of the Miami Dolphins' football stadium, turning it into the Hard Rock Stadium. This is an 18-year deal costing $\$ 250$ million, slightly less than $\$ 14$ million per year. Marketing with the repetition of the name Hard Rock occurs in the advertising of all football games, which include the Miami Dolphin professional and University of Miami college games, along with any concerts or other events held at the stadium. They also added the Miami Open to the Hard Rock Stadium lineup of events. The Miami Open placed even more value on the licensing deal. Key Biscayne, near Miami, previously held the Miami Open. The Miami Open is a tennis tournament held in the spring, usually around March thru April annually. Football season is in the fall, September thru December, with post season following. Additionally, the Brazilian national soccer team will play 6-7 games at the Hard Rock Stadium over the next several years, bringing more 
name recognition to Hard Rock in Latin America. In 2017 the Hard Rock Stadium hosted Real Madrid and Barcelona, and in 2018 they hosted Peru and Croatia in soccer tournaments. This year-round scheduling of events ensures the Hard Rock name recognition. The National Football League (NFL) forbids any association with casinos, but association with music, entertainment, and food, all of which Hard Rock stands for, allows the naming rights of the stadium. Using the Hard Rock International name allows the freedom to use the name to bring sustainability. The use of Hard Rock brings a flood of advertising to all the Hard Rock locations, 43 in the U.S. and 8 within Florida alone. The hope is that name recognition alone might etch in the minds of people that "Indians" still exist and are not going away.

The actions of the Seminole Tribe of Florida are not just money-making ventures. The enterprises display the high priority they place on independence, as well as sustainability and economic development. As stated earlier, the purchase of the Hard Rock International chain, now including the licensing of that name, placed the Seminole Tribe of Florida in a highly leveraged position. However, they are very pragmatic and if they execute their business plan carefully, the profits will eventually pay off the debt. The annual events of the tribal fair, trading of crafts and food, the pow-wow, Rezball, and the rodeo all offer opportunities for members of other tribal entities as well as Seminole Tribe members to learn and take part in cultural events. The opportunity to share funds by way of cultural competition could help other tribal members also start businesses or aid in their economic development. This shows the Seminole 
desire to build strength and their desire to participate in the success of other sovereign nations and their people as well.

The idea of a grocery store seemed important to another Seminole Tribe member. S1 confided that he had asked about getting a grocery store on the reservation, but that the business council had not decided feasibility or tribal support for a grocery store. Interviews with S2 revealed that the Seminole Tribe had done a cost-benefit analysis. Many of the members either live off the reservation, or at the outer edges of the reservation. They think wisely about whether to have independence by having a grocery store inside the reservation or support an existing grocery outside the reservation. They take into consideration how the grocery location would affect an outside store. S2 stated, "In this case, such an investment is difficult to justify". In addition to other business factors, the Seminole Tribe of Florida factors in the benefits to the surrounding communities. Employment at the various casinos, restaurants and events, as well as construction employment for new buildings, provide benefits to the surrounding community. While investing in a grocery store on the reservation may help members living on the reservation who may have to travel large distances to get to a grocery store, it would also negatively affect those grocery stores which members currently frequent. This concern for the surrounding areas attests to the Seminole Tribe of Florida being good corporate citizens (Matten, Crane, \& Chapple, 2003) found to be a common cultural virtue in collectivist societies. 
People who work for the Seminole Tribe of Florida were incredibly happy with their work and felt that the treatment of employees is extremely good. They often spoke of feeling like a part of the Seminole family. This also expresses the balance of life and self-determination (Nissenbaum \& Shadle, 1991; Smith, 2000). As an organization, the investments made in economic development are extremely diverse, with consideration for sustainability of land, tribal members, and the surrounding communities. Ensuring sovereignty and independence are deeply important to the Seminole Tribe of Florida.

\section{Seminole Individual Entrepreneurship}

Several Seminole Tribe members also have independent businesses of their own. Often these entrepreneurs display their products at the tribal fairs, like jewelry, t-shirt designs, traditional clothing, and various forms of art. The Ah-TahThi-Ki museum and The Upper Room Art Gallery hold various art shows and displays of artistic activity of Seminole members. For a while, the Upper Room Art Gallery in Fort Lauderdale worked with a Seminole member who, as one of the last people with the knowledge and skills to hand carve a cypress canoe, would do so on display. While he would carve for a few hours, people could watch, ask questions, take pictures with the artist and collect shavings as fire starters or as souvenirs. Other members have had art shows at the Ah-Tah-ThiKi museum presenting paintings and showing various art forms for the public. A few Seminole members set up food tents where fair goers can get refreshments while attending. Others have local shops that sell items normally found at the fair 
and items more delicate in nature. Many Seminole members have their own business locations or use a pop-up location where that is more beneficial.

Two women at a demonstration event at the Stranahan House in Fort Lauderdale revealed that on the $15^{\text {th }}$ of every month the Seminole members hold a sale/trading event at the Big Cypress Senior Center. Like many of the Seminole Tribe of Florida members, the ladies were at the event to show their artistry. They show the art of making traditional dolls that the Seminole Tribe have sold since the early days of Florida tourism. There were also traditional clothing displays at the Stranahan House for the event. Interviewees S17 and S18 made jewelry they had designed. They displayed beaded rings and bracelets in addition to the traditional dolls that were also available for purchase. The ladies were senior in age and extremely friendly. They shared their Indian names, though pronouncing or spelling them is quite difficult. Interviewee S18 shared, "When I was a baby, the government stole me from my family and gave me to a white family. I didn't know who my parents were until I was old and much of my family had died". She was a Ho-Chunk, formerly known as the Wisconsin Winnebago tribe. In 1974 there was a $1600 \%$ increase in likelihood of the removal of Indian children from their families in Wisconsin (Wilkins \& Stark, 2018) and this has continued to occur as recently as 2013 , nationally. In building rapport with these ladies, we exchanged personal histories and I received a warning not to share background heritage, because the government would take family members. Interviewees, including S18 and S19 shared a great many stories of Native American babies taken from their birth families and adopted by non-Native American families 
(Mannes, 1995; U.S. Department of the Interior, 2016), during this research. Ethnocentrism with Eurocentric ideals has led to misguided policies, in this case state policies, resulting in ripping children from the comfort of their families and raising them counter to their traditional cultural values and causing disruption in tribal cohesion. S18 stays with the Seminole member, learning her own culture while experiencing tribal ways with her Seminole friend.

Interviewee S13 teaches martial arts. He also takes part in demonstrations at some of the Seminole Tribe events about the Seminole wars and showing how they would win in hand to hand combat against U.S. troops is his specialty. S13 also teaches Seminole history, in this case the history of how the Seminole came to learn Jiu-Jitsu. S13 states that monks who came to the area from Asia via Europe shared martial arts knowledge with Seminoles while the Seminoles shared their hand to hand combat and other techniques of survival in the harsh environment of Florida. S13 continues to teach martial arts, together with a group of trained members, and they show Seminole combat methods at various functions as well.

Artistic creativity is common for the Seminole Tribe. Several members have advanced degrees in graphic design and related skills. Redline Media Group has had quite a bit of success and continues to build an employee pool of talented artists. Redline employees may not all be Seminole Tribe members, but their goal is talent, regardless of ethnic background. Redline Media creates video productions used on television and in internet commercials starting with Seminole Hard Rock and expanding into Nike N7, Serta, Kia, and Harley 
Davidson, to name just a few. Producing online commercials is a specialty which they have done for CW networks and Frigidaire, as well as celebrity chef Robert Irvine.

S19 caters various events. Attempts were made to set S19's business up as a Florida International University approved vendor because many of the attendees of a student club event, catered by S19, voiced their desire to hire the business for their own events. A meeting occurred, where I offered to help with the process of setting things up so other clubs and faculty could use the services. Though S19 seemed grateful for the offer, a quiet fell upon the conversation, at his sudden look of embarrassment. S19 said, "I got sick and while I was sick I let someone have power of attorney, so they could run the business. When I got back, things were so bad, I couldn't believe it". The sadness and embarrassment were palpable. "I can't do that right now. My books don't look good right now," S19 stated. Noting that S19 displayed discomfort, the interview changed topics.

In recent times, Native or Indigenous food preparation has become quite the niche trend. Sean Sherman of the Oglala Lakota, known as the Sioux chef, and Baca who identifies himself as an "indigenous food activist" prepare what they refer to as "decolonized" meals with no pork, beef, dairy, processed cane sugar or wheat flour, which are all ingredients introduced to the indigenous diet. They believe that avoiding these ingredients is healthier, hoping to address the health hardship that statistically, according to the Indian Health Service, affects Native American health the most, heart disease. 


\subsection{Economic Development Priorities of the Miccosukee Tribe of Indians of}

\section{Florida}

\section{Cultural and Historical Sharing}

Just as the Seminole Tribe of Florida has an annual tribal fair, usually held early in the year, the Miccosukee Tribe of Indians of Florida also have a tribal fair, usually the week between December $25^{\text {th }}$ and January $1^{\text {st }}$. In 2017 when advertising the tribal fair, and to inform the public about the Miccosukee beliefs and traditions, the Miccosukees ran a public awareness television commercial. The commercial depicts a Miccosukee elder, Joe Cypress, paddling a traditional Miccosukee cypress dugout canoe. While navigating the Everglades a man named Talbert Cypress speaks and in the background a flute plays, the visuals highlighting the beauty of the glistening water, the stunning lilies floating, and then a deep, very somber voice speaks.

"Some of our people call this (paheoke) river of grass, it is where we have lived, survived. We are called (eelapnonke), the people, Miccosukee. (Feshahkee-ommehche), the breath maker, created the land and all living things. All wildlife and human life can wander freely. We have no boundaries, no fences. The breath maker taught us how to understand other people, but to keep our customs and culture. We seek a balance between what is explained and what is secret. He told us, carry on what I have taught you to live by. I will return one day, to see what you have done".

A CBS4 broadcast notation expresses that the heritage of the 600

members of the Miccosukees is still a secret, giving opportunities to highlight the Miccosukee existence in the Everglades, understanding their spiritual life and native language. This Icon is a link to the recorded audio: 
This was one instance of the Miccosukees reaching out to make themselves more familiar to the local communities, while building curiosity and hopefully enticing community members to experience the Miccosukee Arts \& Crafts Festival with them at the Miccosukee village. The village (Figures 5.21-22) is just west of the marking for the Miccosukee reservation on the Tamiami Trail map shown earlier.

Figures 5.21-5.22 Miccosukee Village
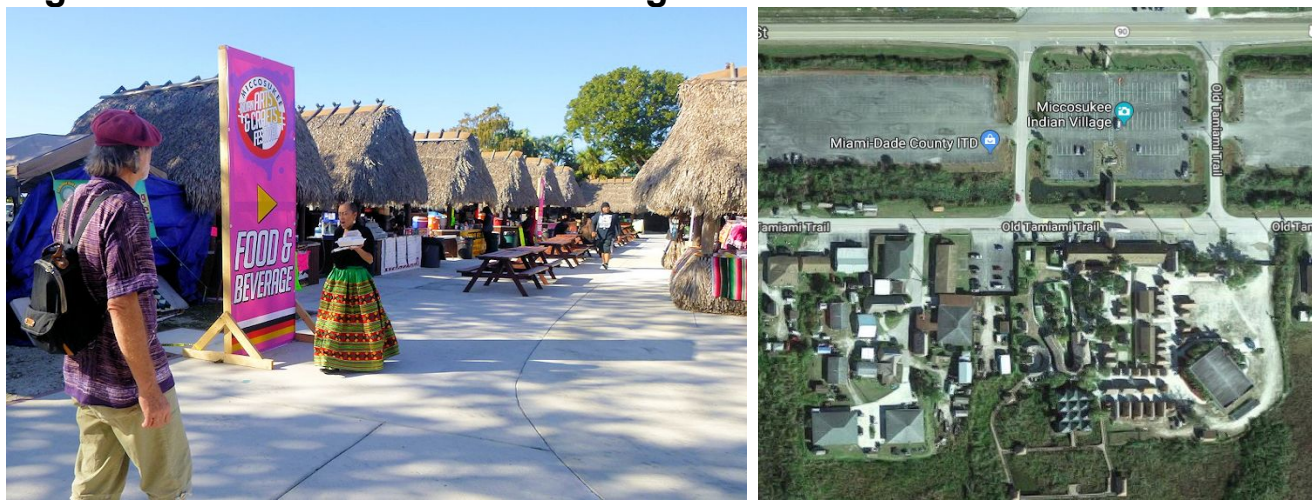

Source: Miccosukee Web Page and Google Earth

\section{Miccosukee Tribal Sustainability}

The Miccosukee Tribe also own several enterprises, including a resort and gaming facility, a world class golf course, a tobacco shop, a service plaza, and tourism attractions like the Miccosukee Indian Village and airboat rides. There is a distinction between the use of casino and gaming. Due to the Miccosukee not using class three gaming, the word casino is not used, rather it is a resort and gaming facility. Miccosukee tourism has been a long-standing business, with demonstrations done within the Miccosukee Village. The casino/resort is on the edge of the most prominent piece of reservation land. Unlike the Seminole Tribe of Florida, the Miccosukee Tribe of Indians of Florida have the single 
casino/resort and are much less accessible both in terms of location and interaction with outside populations. Their population also is much smaller than the Seminole Tribe of Florida, with an estimated 600-640 Miccosukee tribal members. In recent years they have made attempts to be more open.

The Miccosukee Golf Course and Country Club, at 6401 Kendale Lakes Drive, formerly the Miami National Golf Club and before that the Kendall Lakes Golf Club, is an example of the need for understanding of the Miccosukees. In 2001 the Miccosukee Tribe bought the Golf Club. In 2003 they petitioned the Bureau of Indian Affairs (BIA) to place the land under the federal trust with all other reservation land held in trust for them. The Miami-Dade government has fought to stop the transfer of the land, because the transfer would remove local authority and place it under federal authority, with the Miccosukee tribal government controlling the land for the tribal members. The transfer would also free the 229 acres of property taxes (over $\$ 65,000$ reported in 2015), along with fees and zoning restrictions. The local government argues that surrounding communities worry that the Miccosukees would build another casino on the land. Once transferred to federal land held in trust, the local government could no longer tax the property, so there is also the possibility that the loss of tax revenue is the major concern. The original golf course had a 99-year zoning restriction forcing the land to remain a golf course until 2071, but if transferred to the Miccosukee land trust the zoning restriction would be void. The Miccosukee Tribe has told the concerned county authorities that they have invested $\$ 4$ million in upgrades to the golf course, bringing the golf course up to the Professional 
Golfers' Association of America standards. They argue that they would not have invested such a sum if they intended to change the usage to a casino. Figures 5.23-5.24 are aerial depictions of the Golf Course areas that have been a contentious subject for Miami-Dade County. The first is a close-up of the center area, while in the second graphic the same area is the red dot with the horseshoe shaped golf course surrounding it.

Figure $5.23-5.24$ Overviews of the Miccosukee Golf Course
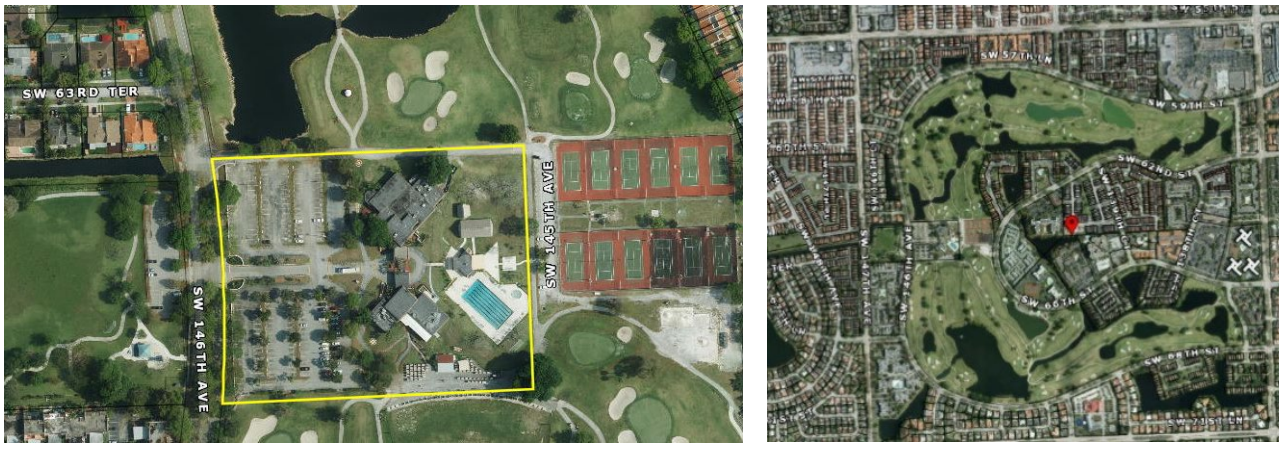

Source: Google Earth

Those familiar with the Miccosukee Tribe of Indians of Florida know that they place a much higher value on the land itself than the buildings on it. The commercial mentioned earlier shows the love that the Miccosukee Tribe holds toward the land. The relationship is more than just respect for the land. Thinking in terms of religion might help understand the Miccosukee relationship with land, water, and all other matters of life. Historically, the Miccosukee Tribe have passed their teachings down, generation after generation. The teachings reinforce that Breath maker (God), charged them with the responsibility to care over the land, at least that which they live on, with the injunction that they take care of the land in a way that honors the mother of creation (Mother Earth). 
Believing that they come from the earth, the Miccosukees desire to protect the land, preferring to keep it as pristine as possible. Though the stories of creation can vary between religions or regions, coming from the earth is like the Christian idea that they are from the earth and to the earth they return, as in ashes to ashes and dust to dust, a concept often recited at Christian funerals.

Like the Seminole Tribe of Florida naming of the Miami football stadium the Hard Rock Stadium, the Miccosukee Tribe has their tribal seal on the Miami Marlins baseball stadium. This is a very subtle but effective form of advertisement. Many of the non-tribal gaming facilities have taken exception to the Miccosukee seal on the outside of the Marlins stadium. The Miccosukee Tribe entered into an agreement with the Marlins for advertising while the Marlins were still playing at the former Pro Player, now Hard Rock Stadium. Because the Miccosukee Resort and Casino does not offer sports betting, Major League Baseball (MLB) does not take issue with the agreement, though they prohibit any affiliation with any organization that allows sports betting, not just betting on baseball games. On 4/3/12 the partnership made news headlines in Sports Business Daily, as the Marlins announced both Pepsi and the Miccosukee resort as quadrant sponsors of the new baseball park. The Dolphin Mall also advertises that they have a partnership with Pepsi and the Miccosukee Resort and Casino, listed under the Partners tab of Dolphin Mall's website. The Miccosukees also sponsor news outlets during breaking news or morning news, displaying the Miccosukee tribal seal on the television screen. 
A few of the partnerships consist of buying advertisements in various other forms for the Casino/Resort. From 2002 - 2010 the Miccosukee Resort and Casino sponsored several NASCAR teams; however, in 2010 the Miccosukee Tribe of Indians of Florida held an early election replacing the tribal chairman, with the desire to go in a different direction.

Some of the partnerships are not investments in advertisements as much as they are efforts to build consensus with local partners to ensure the safety and care of the Everglades. In 2017 and 2018, the Miami Heat basketball team collaborated with the Miccosukee Tribe of Indians to support the cleaning of the Florida Everglades. The Florida International University Crest Center for Aquatic Chemistry and Environment partners with several local organizations including the Miccosukee Tribe of Indians, sharing data and access to Native American students for recruitment. In 2016, Miami City Commissioner, Francis Suarez, collaborated for the seventh year with both the Miccosukee Tribe of Indians and Magic City Casino, both providing the funding used to distribute turkeys to Miami residents facing hardships during the holidays.

While looking up the land area of the Miccosukee Tribe of Indians' casino and tobacco shops, I discovered that the Miccosukee Tribe of Indians of Florida have invested in land in that area as well, transferring the purchased land to reservation land as they had wanted to do with the Golf Course purchase. Below (Figures 5.25-5.29) are aerial depictions of the land, with the red dots showing Miccosukee Tribe of Indians ownership. The first graphic displays the Miccosukee Tribe of Indians' casino/resort in the top left corner. The red dots 
continue as you travel east on SW $9^{\text {th }}$ Street from Krome Avenue. The second area is as you travel south, with the red dots appearing on the east side of Krome Avenue. An identifier in the second graphic shows the same location as the third graphic. Again, in the fourth graphic as you travel south along Krome, the curving road is SW $88^{\text {th }}$ Street, also known as Kendall Drive as it intersects Krome Avenue.

Figures 5.25-5.29 Aerial photos of land identified as Miccosukee owned
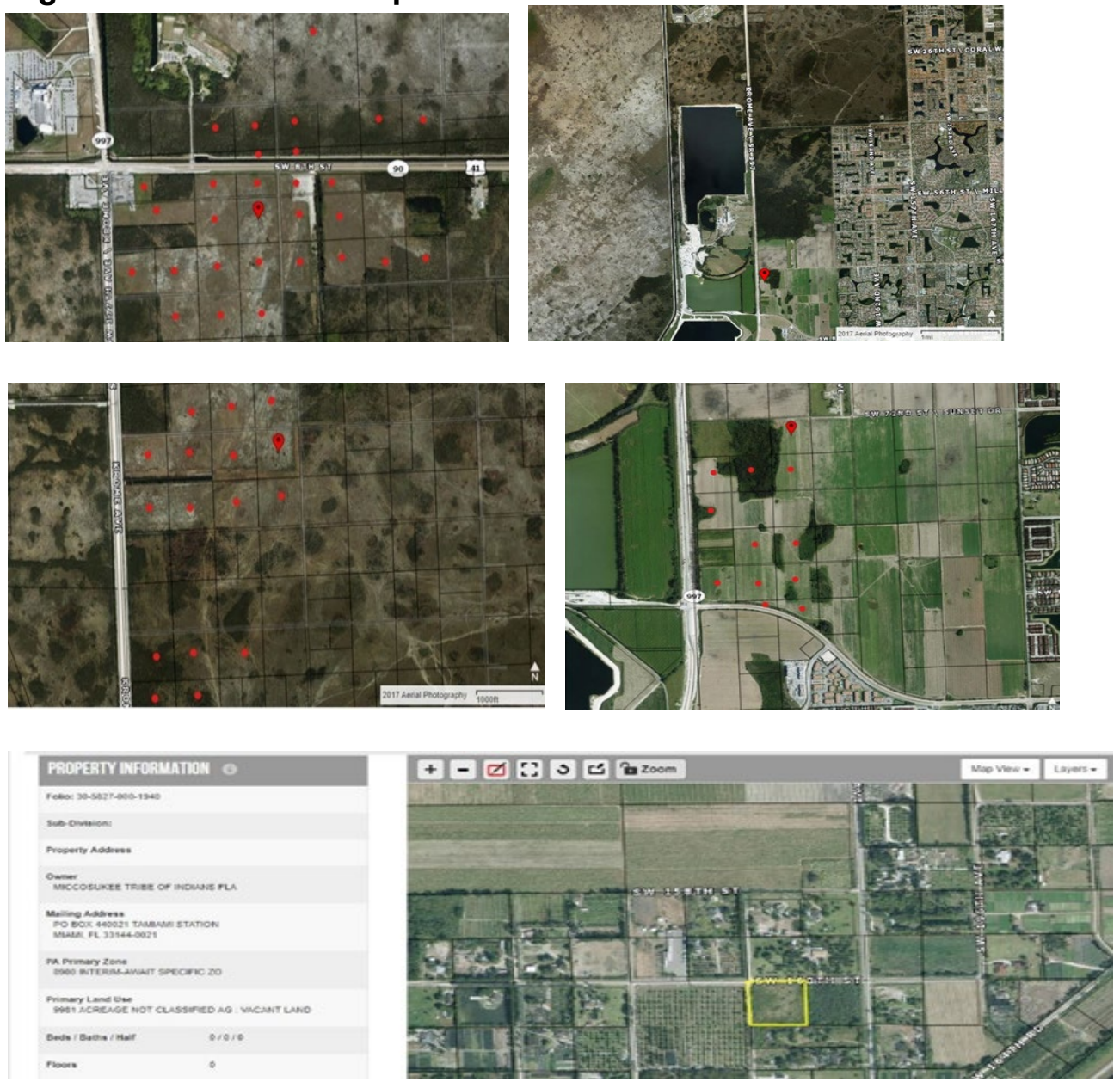

Source: Miami-Dade interactive map 
One final area found under Miccosukee Tribe of Indians of Florida ownership is in the graphic above. It is further south, along SW $164^{\text {th }}$ Street.

Figures 5.30-5.33 Photos of farmers markets supported by Miccosukee tribe
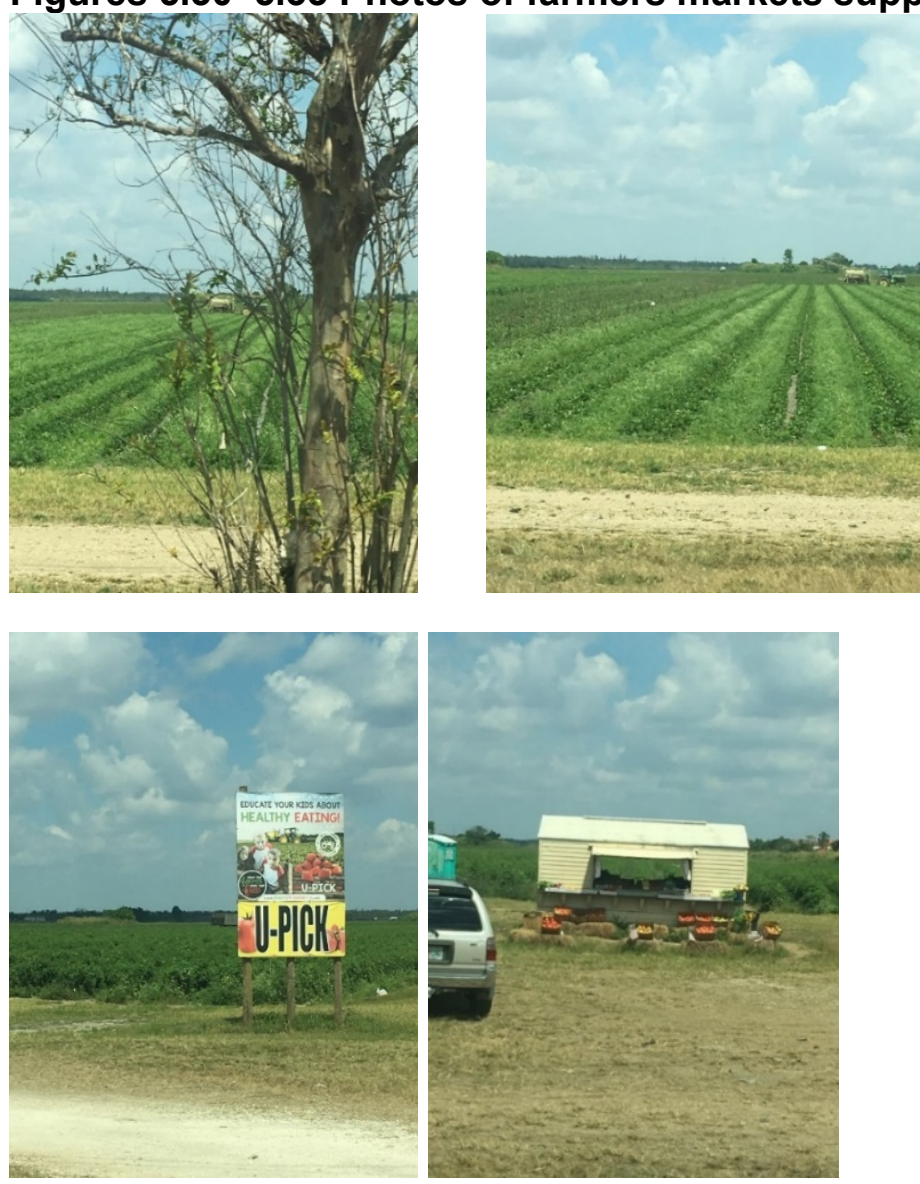

If the Miccosukee Tribe wanted to build another casino, they could do so easily as they already own enough land to do so. It appears more likely that they are trying to protect the land by preventing development through ownership. People in the area are not aware of some efforts that the Miccosukees undertake to help the general population. For instance, they provide fresh vegetables. There are a few U-pick markets provided by the Miccosukee, such as those 
shown in the photos (Figures 5.30-5.33), giving families an opportunity to teach children about food, how it grows, and the benefits of locally grown foods.

\section{Miccosukee Individual Entrepreneurship}

Like the Seminole Tribe of Florida members, some Miccosukee Tribe members have small businesses. There are a few independent airboat companies that run their own airboats for tourists. There are a few small restaurants as well, and several shops that sell bric-a-brac, handmade for use when making clothing. This type of activity is clearly for internal trade rather than attracting funds toward the tribe. The sale of traditional clothing with intricate design is also available. The work is beautiful but expensive due to all the work that goes into every piece. It is not like making a purchase at a department store where there are 20 identical pieces, mass made and ready to buy. You can see the pride and craftsmanship that designers put into every item.

Some of the Miccosukee natural talents have led to very successful musical careers, with recording deals and independent songwriting. Throughout their individual careers, the ties to their clan and customs stay strong. Many types of arts have received prestige through Native American and various other Indigenous artists.

There are also craft sales on the Miccosukee camps, like the sales that the Seminole Tribe of Florida hold at the gymnasium monthly. The Miccosukee Tribe also supports both Seminole and Miccosukee events, having individuals selling food or other commodities. It is not unusual to see Miccosukee members selling their goods at a Seminole event and vice versa. There has also been 
advancement on privately owned food trucks appearing on the reservations. The Miccosukee are not as aggressive in economic development, taking more measured steps along the way.

\subsection{Shared Economic Priorities and Concerns}

The main concern for the Seminole Tribe of Florida is protecting their sovereignty and independence, ensuring that they do not miss any challenge, especially legal challenge to their sovereignty. The Seminole appear to have developed several business plans with timelines and contingencies, and these plans were not subject to open discussion.

The Miccosukee Tribe are involved in many environmental issues. When

first speaking to one of the chairmen of the Miccosukees about the research topic and interest in economic development from a Miccosukee Tribe of Indians' perspective, he connected me with a lady in Washington DC, Debbie Ho, who is founder of Mapetsi Policy Group. The Mapetsi Policy Group has represented the Miccosukee Tribe of Indians of Florida and other tribes around the country on matters in Washington DC. Debbie Ho is a successful attorney, authorized to practice law in Mississippi and Washington DC. Her earlier work included several governmental agencies around the White House and the Department of Justice. She advocates for tribal governments on policy matters with a team of other highly skilled lobbyists. Several of her staff are from various US tribal entities. She shared that the only work that the Mapetsi Policy Group has done for the Miccosukee Tribe of Indians of Florida has involved environmental issues. Much 
of the work was in efforts to help the Miccosukee Tribe preserve the Everglades and minimize the damage done by pollutants affecting water safety.

Several tribal members, both Seminole Tribe of Florida and Miccosukee Tribe of Indians of Florida, are distressed over the dumping of phosphates into the natural waters in and around Florida, which causes algae to bloom. Fracking for natural gas is also a major concern for many of the tribal members from both tribes.

It seems that, annually, the Miccosukee Tribe of Indians of Florida leads an effort to bring awareness to issues negatively affecting the Everglades. In 2016, over a five-day period, several Miccosukee and Seminole members, along with several independent environmentalists and Florida citizens concerned with the construction of a bicycle path across Florida, decided to walk in protest along the proposed path on Tamiami Trail. They called the adventure the Walk for Future Generations, which was to protest building the bike path along the Tamiami Trail, causing widening of the roadway which was already encroaching on the Everglades, affecting the wildlife and waterway. The acronym ROGG refers to the bike path, named the River of Grass Greenway. Bobby C. Billie (who died recently on 4/9/18) of the Original Miccosukee Simanolee Nation Aboriginal People, and Betty Osceola, a Panther Clan Miccosukee Tribe of Indians of Florida member organized the protest walk. The walk started at the S334 Pump Station near the Miccosukee Resort and Gaming facility and was to end at a Seminole family camp on the Naples end of the trail. The group walked in line, two people in each row. The people attending this walk included small children, 
some carried in baby backpack transports, and older walkers, some in their $80 \mathrm{~s}$. The group was about evenly divided between men and women. They came from northern Florida, around St. Petersburg and Jacksonville, as well as both coasts of south Florida. Each day the group, traveling $10-15$ miles, would walk in silence. Transportation, provided by the Miccosukee, would take people to the camp grounds on Tamiami Trail where everyone set up camp to get a good night's rest. Some, like myself, would jump in the car, drive back to Miami to sleep, and return at 6:30AM to participate in the next day's walk. While walking, the group learned from Betty and Bobby $\mathrm{C}$. Billie about the various changes that the two had seen, having lived all their lives within the Everglades. They discussed what was happening to the wildlife and environment. We saw plants like wild bay leaves. Instructing us to use one of the wild bay leaves as aroma therapy, rubbing it between our hands and smelling it for rejuvenation to lower fatigue was helpful and enlightening. The guides highlighted the beauty of the Blue Heron when seen, but also associated this with the reduction in numbers that our escorts had been seeing over the years. They would show us how, due to ever expanding development and contamination, the water was not supporting the amount of wildlife that it once had. Because the water did not have the abundance of fish, frogs, and other food that the birds would have fed on, they no longer could survive with the meager water wildlife. I was deeply moved when Betty asked the people to walk in silence and try to hear nature speaking to us as we walked. She said, "Every day Mother Earth is beaten and cut as man tears at the layers of her skin without regard for her or the love and abundance she has 
given man". As she spoke, tears rolled down her face and you could hear in her voice the sincerity and love for Mother Earth, the passion and compassion as we saw earth not as an inanimate object without feeling, but as a loving 'being' represented by the life-giving abundance provided to the inhabitants. Though I only walked three of the five days, the walk was both exhausting and fulfilling.

It was clear, as we walked, that people would not use the proposed ROGG bike trail much. The trail has no overhead canopy, so the long biking trail with few rest stops would not be pleasant. The sun's intensity and heat would challenge the most ardent bicycle rider, even those involved in heavy training. A real possibility existed of bicycle riders experiencing heat related issues and needing emergency help. That in turn would affect the traffic flow, which appeared highly commercial. Along the way, leaders of the walk pointed out the disruption to the land as the widening of the road had begun. As we reached the final day of the walk, several Seminole members were also able to join. Upon reaching the end of our journey a family opened their camp, where they had prepared food and drink for all the walkers. Bobby C. Billie performed the blessing, and despite mosquito and ant bites everyone enjoyed the prepared food and drink, took a moment to relax, and then returned home exhausted. In 2017, due to work obligations, I was unable to join the walkers as they travelled from the Miccosukee Tribe of Indians of Florida casino to the government building at $111 \mathrm{NW} 1^{\text {st }}$ Street in Miami. Since Betty Osceola always assumes the leadership of these organized events, I asked her what Florida International University or the student club Global Indigenous Group (GIG) could 
do to help. For the first time, she asked us to give them lunch and refreshments as they would be walking on SW $8^{\text {th }}$ Street, past the university, in their journey. We were delighted at the opportunity to reciprocate; the Miccosukee Tribe of Indians of Florida had always afforded opportunities for us without allowing us to help them. Professors donated funds and Global Indigenous Group prepared tables of sandwiches, fruit, skewers of meat, and beverages for everyone. We had several canopies set up with blankets laid out on the ground, so people could find shade, eat, and rest before restarting their journey. The photos below (Figures 5.34-5.37) give an idea of the participation for 2017.

Figures 5.34-5.37 GIG lunch for walkers at FIU
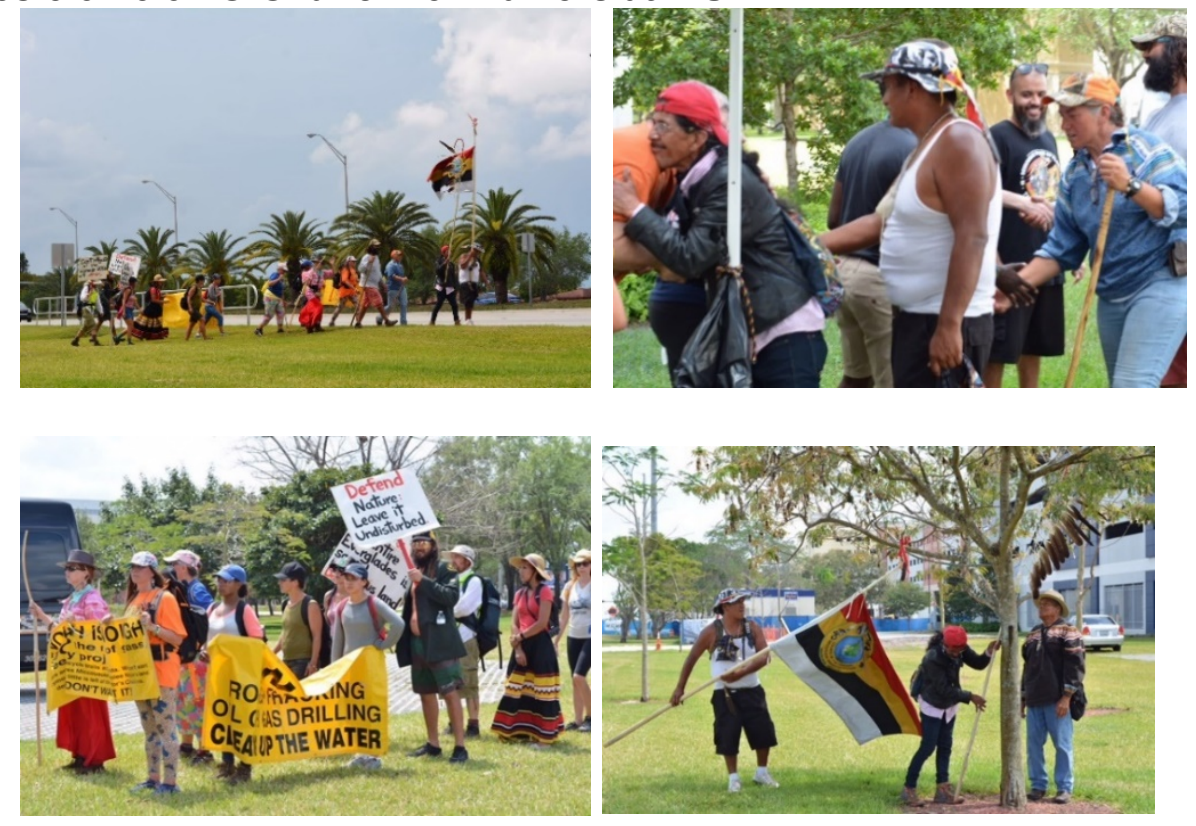

Various trips taken with the Miccosukees show the significant concerns that they have over environmental issues. We visited one of the Miccosukee tree islands reserved for the school children to learn traditional lessons. On this trip 
the children had not been able to use the island due to flooding caused by the Florida water management-controlled water releases north of the islands. This water control, which floods many of the islands, happens every time the water near Lake Okeechobee gets high. The water had just receded enough for the island to be muddy but bearable. We saw clumps of sugarcane in various spots around the island, which became a nice treat as one of the members cut down a stalk and chopped and shaved pieces for the group to chew to get the natural sugar from the cane. The plant is very fibrous and releases only a little sugar when chewed. Betty Osceola offered the rest of the stalk for personal use. She said to plant the stalk by laying it just under the ground and it would sprout on its own. As promised, after planting it a couple of inches deep, within weeks several stalks came poking out of the ground. Monitoring the sugarcane plant closely is important because it can easily overgrow, taking over any ground to which it has access. We cut the sugarcane stalks multiple times a year, some going to neighbors and planting others in new locations. It seems to be much like bamboo in that it travels as it grows until you stop it. It is important for the camp to teach children their cultural heritage, to share in experiences that are passed down in a natural cultural setting.

A display of concern for the needs of this very small, very significant group of people from the state/federal government could help multiple populations; working together with the Miccosukee people to find ways to reduce both the amount of phosphorous in the water, which would positively affect all of South Florida, and reducing Lake Okeechobee waters without flooding the Miccosukee 
people. Engineering solutions are available, if the will to make a change exists. These experiences showed just how important the land, especially undisturbed land, is to the Miccosukee Tribe of Indians of Florida. Miccosukee traditional ways are more in line with Smith's rational choice, "Thus those tribes desiring to live in traditional ways, and who are able to sustain that lifestyle, are making rational choices concerning their resources: this is the very definition of selfdetermination" (Smith, 2000, 357).

\section{Summary}

Members of both tribal groups expressed that, among the priorities, economic development meant independence for the tribal government and a protection of their sovereignty. They also spoke of economic development being a part of their direct democracy, saying that it is the people who should decide whether to approve an economic development project. These were part of the democratic decisions that the people make while considering whether the effects of that decision will positively or negatively affect their children and grandchildren. This was extremely important to members. Sustainability for them lies not just in the economic outcome but also in the environmental outcome. Having money was not as important to either tribal group, without preservation of the health and safety of the land and by extension the health and safety of the members. This supports the concept that a values-based approach to business leads to sustainability, particularly ecological sustainability (Dyllick \& Muff, 2016; Zhao \& Roper, 2011). 
Chapter 5 has reviewed both the Seminole Tribe of Florida business and community activities as well as the Miccosukee Tribe of Indians of Florida business and environmental activities. There are indistinct differences in the perspectives and characteristics of the two tribal groups. The Seminole Tribe members are much more economically progressive, whereas the Miccosukee Tribe of Indians of Florida are still traditional. Though this difference may have contributed to what separated them, there is also the need for separate constitutions and separate recognition by the US government. These tribal entities are and have always insisted that from the beginning they were separate. Members of both tribal groups set up small businesses including artistic expression through various mediums. The Seminole Tribe of Florida have been fortunate in hiring extremely talented professional help from outside the tribal entity who have performed enormously well in advocating for the Seminole Tribe of Florida people and their businesses. The Miccosukee Tribe of Indians of Florida, it appears, are less comfortable with outside talent. They once bought a bank in the hopes of developing banking business. To their dismay, that type of business is extremely regulated, requiring much more involvement with outside individuals than the tribe desired. They decided that, at least for the time being, banking was not of interest and sold the bank rather than endure the scrutiny. Interviewee N4, a casino evaluator and Native American fiction writer, said that the Seminole Tribe of Florida is very pragmatic in their approach to improvement of their casinos as well. They make incremental changes and 
improvements. The improvements he saw at the Miccosukee casino/resort were more sporadic.

Chapter 6 looks at the relationships between the tribal governments and their interactions with local, state, and federal governments. There are opportunities for public administration to understand both types of governmental entities, and in doing so, they can work together for the professional development of both organizations with a common goal of cooperation and success in the interactions between governmental entities. 


\section{CHAPTER 6: INTER-GOVERNMENTAL FACTORS}

\section{Introduction}

This chapter reviews inter-governmental exchanges between the tribal governments and federal, state, and/or local governments. The major case for the Seminole Tribe of Florida focuses on their interaction with the Florida State government in renewing a gambling compact negotiated between the Seminole Tribe of Florida and the State of Florida. The case for the Miccosukee Tribe of Florida involves the interaction with the Federal Government in an IRS investigation. These interactions between governments influence economic development; this is equally true for local city managers (Agranoff \& McGuire, 1998), since more projects involve inter-governmental cooperation due to the fact, they affect surrounding areas as well.

Establishing a government is never easy to do. The U.S. federal government experienced growing pains that went unnoticed, because until the Budget Enforcement Act of 1990 created caps for discretionary spending and rules for taxes and certain entitlement programs, there was very little oversight. With the advent of data availability and the Internet, citizens can now see and review the data themselves, and only since 2006 with the signing of the Federal Funding Accountability and Transparency Act, amended through the 2014 DATA Act, has the US federal government started to implement data transparency. As of May 9, 2017, all federal agencies needed to begin reporting their expenditures. 
By any measure, the Native American tribal governments have done remarkably well in accommodating rules that changed their traditional government structures and activities. Tribal governments had a form of government prior to colonization, and as with all learning, changing the norm takes time and needs adjustments. Some tribal governments adapted more quickly to this change. As pointed out earlier, the Seminole and Creek (Muscogee) were part of the "Five Civilized Tribes", due to their ability to adapt rapidly to changing environments. This provides context for the following interactions between the US federal government and the Miccosukee tribal government.

As these interactions are reported through news coverage, media priming and framing of issues is relevant. Public administrators should review this exchange with the goal of improving the outcomes of intergovernmental relationship(s) and consider the impact the interactions have on various stakeholders.

\subsection{Federal relations}

In April of 2010 there were reports that after 20 years of being the leading tribal chairman, the IRS was auditing a former chairman of the Miccosukee Tribe. The IRS had issued summons to the Miccosukee Tribe's bank, Morgan Stanley Smith Barney, requesting credit card statements and other tribal financial records from 2003-2005. Since tribal governments use the casino income to supply services to their members, like any other government, this is not taxable. However, this summons was not about taxation of the casino income, but 
disbursements made to any person, including the former chairman. Such distributed income is taxable on an individual basis (Weaver, 2010, para. 22).

In June 2010, the IRS investigation suggested that the former chairman charged at least $\$ 3$ million on tribal credit cards for personal travel to casinos in Las Vegas, Foxwoods, and other gaming venues between 2003 and 2005. The IRS reported that they were also working on a civil investigation of the distribution of gambling profits to 650 members, estimated to amount to about $\$ 61,000$ per person annually (Weaver, 2010, para. 2-3).

In August 2010 US District Judge Alan S. Gold said he would make the decision on whether to quash the IRS summons for the 2003-2005 credit card statements of the former chairman, along with the names of other tribal members authorized to use the Morgan Stanley account during that same period. Sonia E. O'Donnell, the Miccosukee attorney, agreed with the judge that it is "wellestablished law" that the IRS can impose taxes on the income of Indian tribal members (Weaver, 2010, para. 5).

In February 2012, the Miccosukee members blamed their former lawyer, Dexter Lehtinen, in a malpractice lawsuit suggesting that he provided "faulty advice" when he told them that they did not have to pay taxes on their gaming profits. With penalties and interest the amount owed the IRS had reached \$26 million. The article also reported that the former chairman owed $\$ 6.65$ million including penalties and interest on $\$ 2.8$ million (Franklin, 2012, para. 2-7). In May 2012 two gambling patrons of the Miccosukee casino filed a lawsuit against the tribe for not sending the withholdings of federal income tax 
from their winnings to the IRS. Upon winning $\$ 5500$ the Miccosukee withheld $\$ 1500$ in federal income tax, issuing W-2G forms reflecting that income and withholding information. When they filed their income tax, the IRS sent notice demanding payment, saying that the funds withheld by the Miccosukees had not been remitted to the IRS (Garcia-Roberts, 2012).

In July 2012, the Miccosukees filed a lawsuit against the former chairman alleging embezzlement of \$26 million from the tribal government between 2005 and 2009, including $\$ 11.5$ million at ATMs (Safdar, 2012, para. 2-3). When asked about the alleged embezzlement, Miccosukee members were very guarded in their opinions. Some felt that it probably showed a lack of oversight by the council, but it may also have been due to lack of understanding of gaming requirements, and blindly trusting in the lawyers.

In August 2012, the Miami Herald reported that the IRS was escalating the investigation into the Miccosukee finances showing payments of profits to tribal members. Miccosukee lawyer Bernardo Roman III said that "the Miccosukee Tribe is not subject to income taxes, yet the IRS seeks all of its records based on sections of the tax code that do not even apply to the tribe" (CBSMiami.com Team, 2012).

In October 2012, the IRS reiterated that individual members of a tribe are American citizens as well as tribal members and are therefore taxable. Despite the arguments set out by Miccosukee attorneys, the $11^{\text {th }}$ US Circuit Court of Appeals ruled for the IRS, allowing them to subpoena bank records. The tribe itself is exempt, the article explains, but they handle deductions and withholding 
of income tax from revenues paid to tribal members. At this point the Miccosukee Tribe acknowledged that at least 100 members owe the IRS more than $\$ 25$ million in taxes, penalties and interest (Wood, 2012).

In November 2012, a three-judge panel of the $11^{\text {th }}$ Circuit Court of Appeals ruled that the IRS can subpoena banks for records. Tribal officials argued that the records would reveal confidential financial information forcing them to change practices and keep money on the reservation. The judges decided that the records belonged to the banks and not the tribe and turned them over to the IRS. The article states that the Miccosukee Tribe had also filed lawsuits against two former US attorneys and the former chairman alleging that the three conspired to hide the theft, whereas the three men denied the allegations (Schreier, 2012).

In December 2012 Robert Wood, a San Francisco practicing attorney, wrote an article clarifying the difficulties in figuring out tax liability for Tribal governments. Not taxing a Tribe, he suggests, is like not taxing France or Germany, but that income when paid to tribal members, because tribal members are also US citizens, is taxable. He goes on to explain, however, that despite per capita distributions being taxable, the General Welfare Exception from income (GWE) exempts from income some payments made to individuals, both Native Americans and non-Native Americans, when the payments happen under legislatively given social benefit programs for the promotion of general welfare. He clarifies that the General Welfare Exception is not in the Internal Revenue Service Code but is, and has been for over 55 years, recognized by the courts and Congress. "To be excludable under the GWE, a payment must (1) be made 
under a governmental program, (2) be for the promotion of general welfare (that is based on individual, family, or other needs), and (3) not represent compensation for services". He points out that this exclusion has been used for payments to adoptive parents to help in raising adopted children and payments by a city to residents moving from flood damaged residences and is common. Regarding Native Americans, educational aid and contribution to employment training skills have been exempt. Wood notes that "the IRS wants to provide clarity and certainty to Native American tribal governments and consistency in the application of the GWE" (Wood, 2012, p. 1241).

A Tampa Bay Times article updated March 2013 suggested that the Miccosukee Tribe had proposed that tribal members may owe $\$ 26$ million to the IRS because of bad legal advice from their former attorney Dexter Lehtinen, husband of US Representative lleana Ros-Lehtinen. It is unclear if the earlier attorneys were referring to legal precedent for GWE, since that was not directly stated.

In August 2013, the South Florida Business Journal reported that former US attorney Dexter Lehtinen was facing a federal lawsuit from the IRS forcing him to turn over records about the Miccosukee Tribe for the 18 years that he was the attorney for the tribe. Lehtinen had told government attorneys that he would not give the documents without a court order. The tribe had also filed suit against Lehtinen for malpractice, which Lehtinen had been contesting (Brinkmann, 2013). In November of 2013, a federal judge warned the current Miccosukee tribal chairman that fines would be charged if the chairman continued to defy the 
judge's order to turn over income tax and other tribal financial documents to the IRS.

In November 2015, the tribal council removed the sitting chairman from his position of leadership of the tribe and named an interim chairman. However, in March 2016 the Miccosukee Tribe returned the former chairman to his leadership position (Weaver, 2016). It may seem odd to have returned the former chairman to his position in the middle of an ongoing tussle with the IRS, but since the chairman had previously led the tribe for nearly twenty years, many members felt that perhaps he understood the issue better. Weaver further states that the Miccosukee Tribe never submitted a "revenue allocation plan" to the Bureau of Indian Affairs indicating how funds were to be spent on general services and distribution to members. The revenue allocation plan is a plan that must be submitted and approved by the Indian Gaming Regulatory Act of 1988 (Public Law 100-497), if they intend to make per capita payment from net gaming revenues. Per capita payments are "distributions of money or other items of value to all tribal members, or specific groups of members, directly from the net revenues of tribal gaming activity. This does not apply to payments which have been set aside by the tribe for special purposes or programs, such as payments made for social welfare, medical treatment, education, housing or other similar, specifically identified needs" (Bureau of Indian Affairs [BIA], 2013, 290.6).

On January 10, 2017, the Miccosukee Tribe of Indians of Florida and Sally Jim appealed to the $11^{\text {th }}$ Circuit Court of Appeals. Of the over 100 members that owed taxes, according to the Miccosukee Tribe, the IRS sought one person, 
Sally Jim. Attorneys state that the Miccosukee Constitution organizational structure predates federal recognition and that the federally approved Constitution states that the Miccosukee Tribe's purpose is to promote the general welfare of the Miccosukee Tribe and to conserve their lands and resources. The Miccosukee Tribe set up the right to levy and collect fees or taxes associated with the tribal land. The document states that in 1984 the Tribe implemented a gross receipts tax and imposed it on the gross receipts of all businesses running within the authority of the tribal land, including tribal businesses.

A July 8, 1970 a New York Times article said that the Mobile Oil Company had discovered a pool of low-quality oil on land that drained directly into the major water conservation area that supplies Everglades National Park. The Seminoles had agreed to a 10-year lease on 42,000 acres in Big Cypress Reservation at $\$ 6.50$ an acre initially $(\$ 273,000)$ and $\$ 1.25$ per acre for each year of the lease $(\$ 52,500$ per year or $\$ 525,000)$ totaling $\$ 798,000$, and finding oil resulted in their receiving 12.5 percent of the profits. The Miccosukee had accepted a 10-year lease agreement with Humble Oil Company (now known as Exxon) on 75,000 acres at $\$ 1$ per acre per year $(\$ 750,000)$ and on finding oil .125 percent $(1 / 8)$ of the profits (Nordheimer, 1970). This was not the first venture for Humble Oil. According to James Covington, in 1955 Humble Oil had leased 104,000 acres of the reservation, which was before Miccosukee or Seminole federal recognition, but they had Florida State recognition. In 1955 a Florida cabinet, Board of commissioner of State Institutions, were custodians of the state Indian reservation oil revenue (Covington, 1986). It is worthy to note that 
Covington also states that the Miccosukee required, as part of the lease, that the company train and use Miccosukee members on their work teams, showing the tribe's interest in both economic development and job skills through training.

Covington states that Humble Oil had paid fees amounting to $\$ 32,414.86$ by 1956 , a single year period, after which a delegation of "reservation Indians" requested the release of the oil funds to the Indians. In 1959 a committee formed by then Florida Governor Collins to investigate the "problems" of the Seminole suggested that the "Indian monies held in trust by the state and should be available for medical care for the Indians and in making small loans to the Indians at moderate interest rates" (Covington, 1986, p. 43). This implies that money belonging to the Seminole and Miccosukee people, held in trust, was then used to create loans for Seminole and Miccosukee people at moderate interest rates. In 1984 oil drilling would have included an oil and gas exploration lease agreement between the Miccosukee Tribe and the American Quasar Petroleum Company and Tesoro Petroleum Corporation in 1982 (Waggoner et al., 1981). 
Figure 6.1 Map of Drilling sites

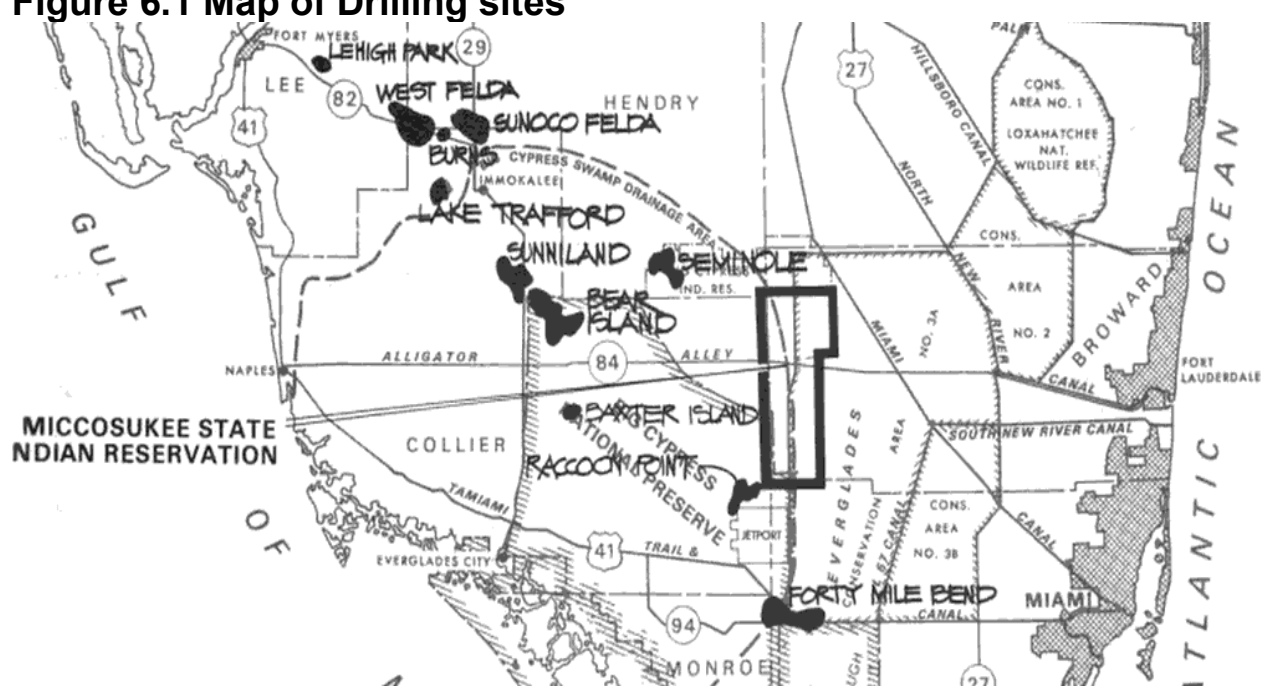

Source: State of Florida Department of Environmental protection

A review of current oil drilling shows only one active well, which appears to be the oil well from the Big Cypress preserve, shown in Figure 6.1 as Raccoon Point. In 1989 the construction of the Indian gaming facility began, with a thirdparty investor/manager. The Miccosukee state that they did not impose the gross receipts tax during the time that the third-party investor was recovering their outlay. In 1990 the gaming facility opened. From 1992 - 2010 Dexter Lehtinen served as primary counsel and recommended to the tribal government that once the third-party investor was no longer involved the gross receipts should apply. They placed the gross receipts taxes into a non-taxable distributable revenue account. The Miccosukees contended that these gross receipts, since 1984, had grown (United States of America v. Sally Jim and Miccosukee Tribe of Indians of Florida, 2016).

The Miccosukees explained their cultural norms, saying that a Miccosukee custom and practice "long before" enactment of the gross receipts tax or the 
gaming facility was to give distributions to each member of the Tribe.

Miccosukees are a matriarchal society, with women as heads of households.

Distributions are given to the head of a household according to tribal custom. The head of the household uses the distributions for the minor children's benefit or saves for the minors until they reach majority. If the head of a household does not save the money for the minor or use it for the minor child, the tribal government holds the distributions in trust for the minor child. Since tribal members are dependent on the Miccosukee tribal government for their general welfare, the tribe had decided that the distributions at issue were necessary to support the needs of the members and the needs of the Miccosukee. The distributions were necessary to sustain the tribal members in their community where they might sustain their separate language, identity, and culture. The final appeal was that the Miccosukee held these beliefs, in good faith, based on advice from counsel.

The tribal member, Sally Jim, was the head of a household that included her husband and two minor daughters. Ms. Jim held a ninth-grade education. Ms. Jim received the distribution following the Miccosukee General Council meetings, where Mr. Lehtinen made recommendations on many legal issues including the taxability of the gross receipt revenues. She believed that the distributions were not taxable. Ms. Jim did not pay taxes associated with the distribution relying on the advice of Miccosukee tribal leaders and attorneys, believing that the distributions were not subject to federal income tax. 
In 2015, former attorney Bernardo Roman prepared a 2001 tax return for Ms. Jim without her knowledge and brought the tax return to her urging her to sign it. She signed the tax return without reviewing it, which listed the distribution to her family as non-taxable general welfare benefits. In 2014, the Government filed a one-count complaint against Ms. Jim and only Ms. Jim, seeking every dollar her family had received, plus statutory additions and interest. The reason the Miccosukee tribal government filed a motion to intervene was that if the decision was "unfavorable to Ms. Jim, it would set a precedent" about the taxability of the tribal distributions (No. 16-17109, 2017).

On $3 / 13 / 2017$, the US court of appeals again found Sally Jim liable for the 2001 tax with penalty and interest and denied the Miccosukee motion to alter or amend the judgment. On 6/5/2018 The $11^{\text {th }}$ Circuit Court of Appeals ruled that the taxes alleged by the IRS were to be paid by the Miccosukee members and the Miccosukee Tribe itself. The court did acknowledge that the general revenue account was not exclusively gaming funds, as was pointed out during trial, but stated that most of the funds were from gaming revenue, which cannot be paid in per capita distributions without income tax being paid. As to the Tribal General Welfare Exclusion Act (GWEA), the court found that the goal was protection from being taxed on benefits received such as healthcare ("Miccosukee Tribe disappointed," 2018, para. 2).

The mindset of the Miccosukee tribal government is unknown. Looking at the issue as a whole, the Miccosukees had earlier experience with receiving funds from contracts with various oil companies for exploration. Distributions 
were normal both culturally and were allowed until the Indian Gaming Regulatory Act, which relates specifically to Gaming revenue. The US court of appeals found that what is clear is that the Miccosukee tribal council did not fully appreciate their responsibility to withhold taxes and send them to the IRS.

It would be easy to believe that the Seminole's progressive ideas and the luck that they experienced of hiring excellent legal counsel have allowed them to prosper without the tribulations haunting the Miccosukee Tribe. Nothing could be farther from the truth. There have been multiple stories, some in the Seminole Tribune, showing that the Seminole Tribe also went through such growing pains. The Seminoles also suffered from management issues and millions in penalties about management contracts for the casinos in Hollywood and Immokalee. A massive turnover in employees and tribal council led to the conclusion that the Seminole Tribe had to "seek employees with gaming experience, overhaul the gaming policies and procedures and revisit and renegotiate many of the contracts" (Bowers, 2003, para. 6).

Between 1981 and 2001, twenty years, the Seminole Tribe had experienced issues like the Miccosukees. James Billie, the chairman of the Seminole nation during that period, expanded gaming, replaced government funded programs with programs paid for entirely by Seminole revenue, built the school and museum and expanded the cattle enterprise. When news stories related the terrible status of Seminole business, Chairman Billie informed readers that they were talking about Indian people who had grown up in poverty, were uneducated, and working in business for the first time. He reminded people that 
they could not compare Seminoles to others who had been growing up in the outside world and amid the white man's business for hundreds of years. He expressed, with pride, that all the mistakes that the Seminole Tribe was making were lessons which would teach them to succeed over time (Gallagher, 2010, para. 46).

Chairman Billie's positive outlook on negative experiences gives hope for the future. The Miccosukees may have received poor recommendations, or communication was not clear, or the Tribal Council thought they could avoid the taxes if they were following customs and traditions, or perhaps the differences required for gaming funding were not understood. One cannot discount that there may be an element of resentment at the fact that the tribal governments, despite enduring an experience unparalleled in history, of being invaded and nearly exterminated, yet after 200 years of refusing to assimilate and fighting for mere survival, have somehow managed to survive and thrive.

The NCIA has passed resolution \#SAC-06-001 titled, "Support HR 4863 for the improvement of Government-to-Government relations with the Miccosukee Tribe of Indians of Florida", stating that the BIA has "failed for many years to fulfill its role as an advocate for Indian tribes and Indian people or to meet trust standards in managing Indian affairs". The "Honorable Mario DiazBalart" introduced the bill in 2006 at the request of the Miccosukee Tribe. The Miccosukee requested this bill "to establish a pilot program to explore the development of more appropriate and effective arrangements for managing relations between the Federal Government and Indian Tribes". They said that 
they would like to work with the Department of State, rather than the BIA, since the Secretary of State could consult with any other government official and would be a more proper diplomat for the interactions in government-to-government relationships with the Native American tribal governments (H.R. 4863, 2006). The mission of the BIA states that the goal is "to enhance the quality of life, to promote economic opportunity, and to carry out the responsibility to protect and improve the trust assets of American Indians, Indian tribes and Alaska Natives". It appears that the mission does not support the reality that the tribal governments experience, whereby they learn through the payments to outside individuals and trial and error.

That is not the only failure of the Bureau of Indian Affairs. In 1996 plaintiffs filed the largest class action in US history, requesting an accounting of 300,000 accounts belonging to Native American Tribes and tribal members, held in trust by the Bureau of Indian Affairs (BIA). Another 1400 tribal accounts also sought reconciliation through separate litigation. In 1972 the BIA declared that it could not reconcile the tribal trust accounts. In the 1980s the General Accounting Office (GAO), along with the Department of Interior and the accounting firm Price Waterhouse, urged reform in various reports. In 1985 the Department of Interior created the Branch of Trust Fund Accounting. In 1991 the creation of the Office of Trust Fund Management to oversee all trust fund investment and accounting duties occurred. A congressional report of 1992 states, "Congress urged reform in 1992 and in 1994 passed the American Indian Trust Reform Management Act, developing a special trustee within the Department of Interior tasked with 
creating a new management plan". As is usually the case, administrators created reports, and reports gathered dust on shelves. The American Indian Trust Reform Management Act requires the 'Individual Indian Money (IIM) trust beneficiaries be provided an accounting of all money held in trust for them'. The leader of the class action litigation, Eloise Cobell (Blackfeet), a banker by profession, argued in 2002 that totaling all individual accounts since 1877, the missing funds would amount to more than $\$ 100$ Billion in 2002 dollars (Nakashima \& Tucker, 2002).

Judge Royce C. Lamberth oversaw the Cobell led class action litigation. Despite Judge Lamberth's conservative background—he was the Reagan attorney that led to the Reagan administration's win against the air traffic controllers' strike—-he repeatedly found for the Native American litigants, at one point saying in his 2005 opinion, "Real justice for these Indians may still lie in the distant future; it may never come at all. This reality makes a statement about our society and our form of government that we should be unwilling to let stand" (Stein, 2005, para. 2). The Department of Interior accused Judge Lamberth of bias, so in 2007 appeals judges removed Lamberth from the case. In fact, the same qualities that endeared him to the Reagan administration, his hawkish approach to government spending of money, marked his approach as he presided over the case. Independent accounting firms tried to help the Department of Interior reconcile the accounts but found that the Department of Interior had "never kept complete records, used unknown amounts of the funds to help balance the federal budget, and let the oil and gas industry use Indian 
lands at bargain rates" (Weiss, 2006, para. 4). During the contention Lamberth vowed to, "expose a cabinet-level agency whose 'spite' has led it to turn its 'wrath' on trust beneficiaries and engage in 'willful misconduct', 'iniquities', 'scandals', 'dirty tricks', and 'outright villainy'” (Steidman, 2006, para. 1). The plaintiff, Eloise Cobell said that the reassignment would "end the truly heroic efforts of a sincere and devoted jurist, the Honorable Royce C. Lamberth, to remedy the century of abuse of Indian people by the Department of Interior" (Steidman, 2006, para. 8). Under the Obama administration, when the US agreed to pay $\$ 3.4$ billion in 2009 , the case concluded. This is a far cry from the amount that Cobell estimated. This included a $\$ 60$ million fund to advance college education (Wilkinson, 2009, para. 1). This is not a condemnation of the Bureau of Indian Affairs, but rather an enlightening of public administration. In serving the public, it is common knowledge that there are scarce resources to distribute among various stakeholders. As public administrators, fulfilling the organizational mission ensures that each stakeholder has access to government and a voice representing them in that quest.

Seminole Tribal government has done exceedingly well while only existing under these rules as a recognized tribal government for 61 years, while the Miccosukee Tribal government has continued to evolve over the past 56 years of recognition. The Seminole and Miccosukee tribes have different goals for economic development. This is clear in the creation of the economic development department for the Seminole Tribe, whereas the Miccosukees created the ecological department. 
Since tribal governments are subordinate to only the federal government, most interaction is Federal unless by choice, as in the case of gambling compacts.

\subsection{State relations}

The interaction between the Seminole government and the State of Florida involves primarily the interactions over the Seminole Tribe gambling compact with the state of Florida. For clarification, the Indian Gaming Regulatory Act (IGRA) set up three classes of gaming in 1988.

Class 1 games are described as traditional Indian gaming which are social in nature and with minimal prizes. This is handled exclusively by the tribal government and is not subject to IGRA requirements.

Class 2 are described as games of chance known as bingo (electronic or not) and played in the same location as bingo. Non-banked card games are played against other players, not against the house or a player acting as a bank. This class specifically excludes slot machines. If the state that the tribe exists in allows such gaming for any purpose, the tribal government adopts a gaming ordinance approved by the National Indian Gaming Commission (NIGC) and the tribal governments are responsible for regulating with Commission oversight.

Class 3 is basically all forms of gaming not covered by class 1 or class 2 , games commonly played at casinos, slot machines, blackjack, craps, and roulette or any electronic version of the same. Final approval of gaming compacts is left to the federal government and all gaming compacts must be negotiated "in good faith" by the state where the tribe exists (IGRA, 2015). 
In 2014 a part of the Seminole tribal compact held with the State of Florida was coming to an end. The efforts to develop an updated compact were becoming increasingly difficult.

The original compact between the Seminole Tribe and the State of Florida, under then governor Charlie Crist, began In July of 2010. Though the compact was for 30 years, the card game provision set the end following five (5) years, unless renewed by the Florida Legislature. The Seminole Tribe was also not to offer these card games at the Brighton or Big Cypress reservation facilities, unless the State of Florida allowed other organizations or entities to offer the games as well. In consideration for this benefit, the Seminole agreed to a generous payout to Florida. Using a scenario of $\$ 5$ billion over the first 5 years of the compact, the lowest revenue sharing value amounted to $\$ 15,530,000,064$. There is also an annual oversight assessment of $\$ 1,250,000$ over the 5 years, and an annual donation to the Florida Council on Compulsive Gambling of $\$ 8,750,000$ over the 5 years. Total payment to Florida amounted to $\$ 15,540,000,064$, of which local governments affected by the gambling establishments were to receive $\$ 466,200,002$. In the case of Hard Rock, the city of Hollywood and Broward County received payment as the local governments affected. A check of those budgets does not show revenue from a compact, but they do mention intergovernmental transfers. A breakdown of the distribution using the $\$ 5$ billion revenue scenario is in appendix $\mathrm{A}$.

As the end of the 2010 compact approached, news stories depicting litigious confrontations between the Florida legislators, Florida governor, and the 
Seminole Tribe were abundant. An examination of the news articles showed the intergovernmental activity. Reviewed from a perspective of diplomacy, the relationship was edifying.

On 2/4/14 an article by Ellan Klas of the Miami Herald, who often covers interactions involving tribal government, showed that the Florida house of representatives, through the speaker Will Weatherford, suggested that the Florida House would be open to allowing gambling elsewhere in the state of Florida. This act would remove the exclusivity of the Seminole and Miccosukee reservations. It should be noted that the Miccosukee do not run gaming needing exclusivity or a compact. The article notes that changing gambling policy would need Governor Scott to negotiate a new compact as well as a constitutional amendment, requiring voter approval of the expansion of gambling in Florida. In fact, the exclusivity of reservation gambling creates the need for a compact. Weatherford suggests that due to loopholes the gambling system is "a very disenfranchised gaming system in Florida" (Klas, 2014, para. 7). The president of an Orlando based group "No Casinos" states that a $\$ 400,000$ analysis of the impact of gambling on Florida's economy suggests that expanding gambling to other areas of the state would have minimal impact. At the same time, Weatherford told Klas that the Florida Senate was drafting a bill to allow casino companies to bid for new permits to set up casinos in Miami-Dade and Broward. Since the compact is not even 5 years along, the submission of such a bill is tantamount to breaking the 30-year compact with the Seminole Tribe. Even as the Seminole Tribe had paid out the revenue sharing monthly per the compact 
and had additionally contributed $\$ 500,000$ to Governor Scott's political committee, while the owner of Las Vegas Sands donated $\$ 250,000$, lobbyists in the state were working to change gambling in Florida.

A month later, on 3/5/2014, the Sun Sentinel reported that, as of April, the Seminole Tribe would have contributed to the State of Florida $\$ 1$ billion dollars since the start of the compact in January of 2008. The article clarifies for readers that if there is no exclusivity in the compact for the Seminole Tribe there is no revenue sharing needed under US law. Additionally, despite Florida ranking third in the nation for total gambling revenues, some in the state were talking of expanding gambling. The rest of the article analyzes the reasons why Florida should renew the compact, including the compassionate statement, "for centuries, Florida Seminoles struggled to gain an economic footing. Our fortunes began to change when the first Seminole Gaming operation opened in 1979". The statement continues, "the Seminole Tribe pushed for a gaming compact with the state of Florida for nearly two decades, a long-term gaming compact means a stable future for 3900 Seminoles" ("Jim Shore Compact," 2014, para. 8-9). Jim Shore, who is the general counsel for the Seminole Tribe, and the first Florida Seminole to become a lawyer, additionally points out that the Seminole "have achieved economic independence and expanded opportunities in education and business as a result". Seminole gaming has also brought 23,000 direct and indirect jobs to Florida and has contributed a billion dollars of goods and services bought state wide. 
In April 2014 Reuters published an article showing that the Florida legislature did not pass the 400 -page bill that was going to expand gambling by allowing the two "destination resort" hotels and casinos in the Miami area. Governor Scott was actively negotiating a new compact before the end of the 5year 2010 pact. Senator Richter of Naples said that the legislature should address the comprehensive gaming reform after the compact was negotiated (Cotterell, 2014).

In August 2014, there was a Tampa Bay Times story showing that the compact negotiations between Governor Scott and the Seminole Tribe had failed. Since elections were to take place in November of 2014, Florida suspended further negotiations until after the elections, so that if legislators changed because of elections, the new members would be in place before negotiations resumed (Rosica, 2014).

Following the election, on March 10, 2015, a Tampa Bay Times article said that the Seminole Tribe would like to expand the casinos and hotels in both Tampa and Hollywood, spending $\$ 1.6$ billion and creating 4,000 permanent jobs. Jim Shore told the reporter that the Seminoles had not heard from Governor Scott, and further that until Florida addressed the compact the $\$ 1.6$ billion projects were on hold (Thaji, 2015).

On March 17, 2015, the Orlando Sentinel printed an interview with the Seminole gaming CEO James F. Allen. Allen stated that the Seminoles had not just met the 2010 compact but had exceeded all revenue projections provided to the state. A scenario of continuing the expiring compact for another 15 years 
showed that Florida would receive $\$ 6.1$ billion from the Seminole Tribe. When asked what their thoughts were when critics suggested that the compact should expire and reduce the gambling in Florida, Allen responded that he hoped 3,000 people being put out of work, including dependents, affecting 5,122 people is not what those people would want. This reflected the number of dealers that the Seminole compact employed. Allen additionally pointed out that the Seminole Tribe, unlike many other casino organizations, has never been in bankruptcy, has never had financial issues, and most importantly the money stays in Florida. Other entities who may gain access to building a resort casino in Florida do not keep their money in Florida, it goes to another state or country. Seminoles spend the money in Florida ("Jim Allen speaks to Orlando Sentinel," 2015).

In October 2015, the Seminole Tribe filed a lawsuit in federal court against Florida, charging that Florida had violated the exclusivity of the compact regarding "banked" games in two ways. By both allowing dog tracks and other gambling locations to hold electronic black jack games and by allowing parimutuels to run card tables for poker and other card games where gamblers bet against each other, the state violated the 5-year exclusivity conditions of the compact (Salinero, 2015).

In December 2015 Governor Scott signed a \$3 billion over 7 years compact with the Seminole Tribe, giving the Seminole Tribe exclusive rights to run blackjack, craps, and roulette. At this time, the 5-year part of the banked card games of the 2010 compact had already expired as of July 2015. Allen had previously pointed out that most South American gamblers played roulette, 
suggesting that the roulette exclusivity allowed the Seminole operations to cater to the South American visiting gambler. With the new compact the Seminole Tribe would expand into the Brighton and Big Cypress casinos with the card games excluded in the 2010 compact. The new compact also expanded the licensing to facilities in Palm Beach and Miami, exposing the Seminole casinos to competition. If the legislators were to grant blackjack to the competing parimutuels in other parts of the state, the Seminole revenue sharing from blackjack would stop. Also, not addressed in the compact was the desire that the Seminoles had expressed about a new Fort Pierce casino that they would like to build (Klas, 2015).

In January 2016 Florida responded to the Seminole lawsuit suggesting that the Seminole had improperly filed the lawsuit in Tallahassee and that, regardless of actions by Florida, the Seminole Tribe, when the earlier compact ended, did not remove blackjack from the casinos. The Seminole response was that they could keep blackjack because the Florida regulators violated the exclusivity of the compact when they allowed the South Florida race tracks to have electronic versions of the card games. The article points out that approval of the Florida compact signed the previous month, December 2015, had not happened. Federal Indian gaming regulators, not just the Florida legislation, must approve the new compact signed by the Seminole chairman and Governor Scott. (Rosica, 2016).

On February 11, 2016, Politifact.com suggested that the Florida legislature had been reluctant to approve the compact previously signed by Governor Scott 
and the Seminole Tribe. The Seminole Tribe, in response, started running commercials designed to inform the legislature and Florida citizens about the benefits of the compact to Florida. Benefits like 20,000 new jobs, $\$ 3$ billion guaranteed revenue and empowering the legislature to limit casino expansion. The article stated that the Florida House Regulatory Affairs Committee had approved a bill to ratify the compact but that the Senate delayed the vote. Politifact.com also tried to highlight the relative amounts other states receive from reservation casinos (Table 6.1). They pointed out that the Miccosukee Tribe runs the $8^{\text {th }}$ casino in Florida but that they do not offer games which need a compact with Florida.

Table 6.12014 Casino contributions to states

\begin{tabular}{|c|l|l|l|c|}
\hline Year & State & Revenue & State Portion & $\begin{array}{c}\text { \# of } \\
\text { compacts }\end{array}$ \\
\hline 2014 & California & 7 billion & 241 million & $\begin{array}{l}73 \text { tribes but } \\
\text { only } 11 \text { paid }\end{array}$ \\
\hline 2014 & Oklahoma & 3.8 billion & 125 million & 124 \\
\hline 2014 & Florida & 2.3 billion & 200 million & 7 \\
\hline
\end{tabular}

Source: Politifact.com

The writer suggested that in the final year of the contract, the Seminoles would pay more to Florida than any other state receives from all tribes they have combined. Politifact.com is known for verifying the truthfulness of any political statement based on their analysis. They suggested that the commercial put out by the Seminole Tribe proposed that Florida was getting the best financial deal of any state in the country, which politifact.com rated as mostly true (Gillen, 2016).

In March 4, 2016, Florida Politics noted that the Seminole compact again died in legislature, unable to get enough votes to pass the bills. At this time 
Governor Scott said that if the compact did not pass 3,700 people were going to lose their jobs, per the Seminoles. The statement shared earlier actually mentioned that the Seminoles employed 3,000 dealers and that the impact would affect 5,122 persons including dependents (Rosica, 2016).

In April 2016, the Orlando Weekly pointed out that Florida, and in fact Florida taxpayers, had paid $\$ 260,000$ thus far to private law firms defending the state of Florida in the Seminole lawsuit, filed October 2015. A Detroit law firm, hired by Florida, would pay three lawyers from the firm $\$ 350$ per hour plus another three lawyers between $\$ 195$ and $\$ 275$ per hour. The state was also be paying a Tampa based firm $\$ 100,000$ to help them on the compact. According to the Indian Gaming Regulatory Act, the states negotiating compacts with tribal governments must negotiate in good faith. Florida lawyers argued that they need good faith negotiating on first compacts, not renegotiated deals that have expired (Kam, 2016).

On October 1, 2016, the Seminole Tribe v. Florida trial was set to begin a year after the Seminole Tribe originally filed the lawsuit (Smith, 2016). Then on November 9, 2016, US District Judge Robert Hinkle ruled that the state had broken an exclusivity deal with the Seminole Tribe of Florida, allowing it to keep its blackjack and baccarat tables until 2030. Since Governor Scott's 2015 renegotiated compact had failed ratification, new negotiations placed the Seminole Tribe in a stronger negotiating position, suggesting that the lucrative deal reached by Scott and the Seminoles was unlikely to repeat (Smith, 2016). 
In January 2017 Florida appealed Judge Hinkle's decision as the Florida legislature considered revamping Florida's gambling laws, stating only that a "leading" Republican state senator "filed a sweeping gambling proposal" which would grant the Seminoles the same right on the card games that the judge granted, but would expand slot machines around the state as well (Fineout, 2017, para. 10).

By July 2017 Florida had decided to stop the parimutuels from offering competing card games, which allowed Florida to receive more than $\$ 340$ million under a settlement agreement reached with the Seminole Tribe. Florida would also stop competing casinos from offering blackjack and slot machines that act as banked card games, honoring the exclusivity of the compact. The Seminole Tribe had withheld $\$ 220$ million in escrow from the time they originally filed the lawsuit and had added another $\$ 120$ million from the following fiscal year (Klas, 2017). In December 2017, the Seminole Tribe filed suit again after discovering eleven (11) electronic gambling parlors operating casino-style gambling, despite the knowledge that Florida Department of Business and Professional Regulation (DBPR) needed to enforce the exclusivity of the compact, again violating the compact. The failure of the DBPR stems from lack of authority over establishments that do not serve liquor (Ferrell, 2017).

As of February 2018, Florida legislators and the Seminole Tribe were yet to strike a deal with a new compact to replace the 2010 compact that they continue to work under, but there was hope that they would be able reach an agreement (Kam, 2018). 
On April 18, 2018, Governor Scott's website announced an agreement with the Seminole Tribe. The compact extends the Tribe's current commitment for revenue sharing through May 2019, paying Florida more than $\$ 300$ million per year. Scott points out that while he has been governor "the Compact has generated more than $\$ 1.75$ billion", helping Florida invest in education and environment. The Seminole Tribe is investing more than $\$ 2.4$ billion to expand the Hard Rock Casinos in Tampa and Hollywood Florida, hiring thousands of Floridians to fill jobs in construction and staff ("Gov. Scott," 2018), according to the Seminole chairman.

On May 8,2018 , a Jacksonville news service ran a story highlighting a proposal that could cost $\$ 50$ million a year and hundreds of jobs. The rule is an address to the pari-mutuel violation of the Seminole exclusivity broken by the pari-mutuel industry. The new language would ensure that the players compete against each other and not a designated player acting as "the house" which is the exclusive right of the Seminole Tribe under the compact. Naturally, the lawyer for the parimutuels considers the change "drastic", pointing to the $\$ 50$ million loss. The alternative, however, should Florida continue to fail enforcement, is a $\$ 300$ million loss of revenue from the Seminole Tribe.

On May 30,2018 , the Tampa Bay Business Journal described the $\$ 700$ million expansion of the Seminole Hard Rock Casino in Tampa. The article additionally points out that the investment made by the Seminole Tribe will also create 2,000 construction jobs during the expansion and more than 6,000 added jobs, according to the casino, pointing out that the Seminole Hard Rock Hotel \& 
Casino is one of the largest employers in Tampa Bay, with over 3,500 employees.

Delving into the Seminole intergovernmental factors, note what seem to be endless litigations, with issues often left unresolved. It may be that the Florida legislature is again going to wait until the compact has expired and try to renegotiate a continued contract. However, in November 2018 mid-term elections will end Governor Scott's tenure and other legislative positions. It is important to watch these negotiations in an effort to see the interactions between the governments and the extent to which Florida leaders adhere not only to the letter of the agreement between the two but to its spirit as well. The competing stakeholders in Florida are an ever-present reality, and it is leadership that prioritizes meeting those competing needs. If meeting the needs of the public is a financial reality, they must ensure there is no litigation paid through tax funding by adhering to contracts. If the compact is supplying $\$ 300$ million and hundreds of jobs, the competition is not $\$ 50$ million and a handful of jobs from the parimutuel industry.

The pari-mutuel industry was unchallenged for decades, taking in years of revenue without adapting to changing demographics and economies. They did not try other forms of gambling until the success with the Seminole Tribe form, which the parimutuels would now like to violate the compact by providing. The pari-mutuel industry should review the larger picture to understand the Seminole success, it is not just the coveted games that bring customers. Rather than trying to duplicate what is, they must evaluate what these locations have to offer, 
compete for the customer desired, and decide what customer brings benefit to the community that the location is in. Seminole Hard Rock Casinos do not compete for the gambler, they offer gambling to the customers that they attract. People that attend parimutuels attend those locations for specific purposes. Though gambling may be the focus with horse race customers, the parimutuels attract those familiar with horses, who love the art of the animal's lines and the majesty of the movements in the race. What about the race track which makes them return customers, win or lose? Emphasis should be on the demographics attracted to that type of event, offering customers more reasons to part with their money.

There have been many interactions between the Miccosukee government and the Florida government, mostly over ecology and environmental issues. The Miccosukee issues with the federal bureaucracy has dissuaded them from negotiating a compact with the state of Florida. If there is no request for concessions in allowing advanced gambling, the Miccosukee Tribe does not need a state compact. For the time being, they are content with their establishments and the economic development they have set up thus far. As the Seminole and Miccosukee Tribes have shown, economic development needs industry to challenge the accepted.

The US Department of Transportation as well as the Florida Department of Transportation have guidelines for transportation planning near Tribal lands. The Federal Highway Administration (FHWA) acknowledges that they have a government-to-government relationship with the 'Indian Tribal Governments' and 
that established consultation requirements exist. They also suggest that they are "committed to building more effective day-to-day working relationships" with Federal and State Governments, Metropolitan Planning Organizations, local governments and Indian Tribal Governments in transportation planning (Tribal Transportation Planning, n.d., para. 3). The Florida Department of Transportation (FDOT) also has a Native American Coordination page dedicated to "build partnerships and address transportation-related issues of concern to agencies and federally-recognized Indian tribes" (FDOT-Native American Coordination, n.d., para. 1). FDOT points out that, effective $1 / 11 / 2001$, there is a requirement to consult with the Native American Tribes, in all phases, when there is a "potential to affect Native American historic properties, on or off tribal lands". Concerning the events related to developing a River of Grass Greenway (ROGG) bicycle pathway, directly affecting the Miccosukee "tribal lands, both on and off the reservation", Miccosukee members state that no consultation occurred. Indeed, the Miccosukee Tribe collected and delivered petitions to the Hendry County and Miami-Dade County Clerk of Courts opposing the ROGG pathway. Acknowledging a goal of inclusion does not affect the change needed to result in inclusion. Inclusion needs strategies designed to result in the actual inclusion in decision making. This is a common issue between the public and governing bodies of every type, resulting in the governed increasingly being discontented with the governing bodies. If state and federal websites are informing the public that they consult with the tribal governments or tribal members as part of their normal course of business, public administrators should ensure that they comply 
with the statements. Not doing so risks the very trust that public administrators have expressed a desire to improve, for decades. The population of the Miccosukee Tribe is so small (at roughly 600 ) that consultation with the tribal government would be known throughout the population.

\subsection{Local government relations}

The tribal governments do not interact much with the local governments. Tribal members who live off the reservation are active members of their communities. As mentioned earlier, the Miccosukee Tribal members addressed county leaders both in Collier County and Miami-Dade County with respect to the River of Grass Greenway (ROGG). The members work to protect the environment, but they are also active in educating others of issues, often gaining widespread support. Collier County Commissioner Penny Taylor acknowledged that the county is supposed to contact the tribal governments regarding concerns before approving such development ("Disrespect," 2018).

Development and support of non-profit organizations committed to environmentalism, like the organization Love the Everglades, includes coordinating events aimed at raising awareness of issues and finding resolutions to them. The issue that Miami-Dade has with the Miccosukee purchase of the golf course is the only significant dealings they have had with local government. That interaction is not between the Miccosukee Tribal government and the Miami-Dade government. The Miccosukee Tribe bought land and under their rights as a federally recognized government, asked the Bureau of Indian Affairs (BIA) to place it into trust for them. It is the normal relationship, federal 
government to tribal government. It is the Miami-Dade government that has petitioned the Bureau of Indian Affairs to not place the land into federal trust for the Miccosukee, out of concern about what the Miccosukee may do with the land. Though the Miami-Dade government may be acting in the interest of their citizens, they do not reciprocate the actions that are obligatory of the tribal members. When the tribal members want to express their concerns, they attend city/county governmental meetings and request to speak. Though Miami-Dade residents could request that the issue of the golf course be part of a tribal council meeting or ask to be informed when it is part of the agenda so that they can express their concerns, this is not normally the case. The tribal government has repeatedly and publicly stated that they do not intend to change the golf course, having invested millions into upgrades of the course. For the local Miami-Dade government, that the function of the golf course will change may not be as much of a concern as the loss of tax revenue, should the land be transferred to trust as requested. The annual tax bill for the last 10 years ranged from $\$ 25,321.43$ in 2016 to $\$ 28,951.79$ in 2010.

At the same time, the Miami-Dade government plans to extend the SR836 expressway closer to the Miccosukee land without any consultation and in what is a violation of Florida Department of Transportation guidelines. No consultation occurred between the Miami-Dade government or Florida Department of Transportation and Miccosukee tribal government about the extension that would affect the tribal lands. The Miccosukee also suggested that SR836 not exit traffic onto SW $137^{\text {th }}$ Avenue but use Krome Avenue that is already under expansion 
(Portal, 2018). This minimizes the impact of construction on the area. In these circumstances, it is difficult to envision an inter-governmental relationship, without mutual respect or reciprocity.

The Seminole tribal government also does not deal directly with the local governments, though the members attend town halls and county meetings as members of the communities in which they live. Many people are unaware of the money poured into their government coffers from the gambling compact. It is often the case that people assume that the tribal members are rolling in untaxed gambling money.

\section{Conclusion}

Inter-governmental relationships are becoming increasingly more important as coordination and collaboration between neighboring communities becomes more common. Communities grow economically together as neighboring communities develop. This includes communities where Native American reservations exist.

When evaluating Native American governmental activity, proper context is important. Knowledge of the history between the US government and Native Americans can explain some of the tensions in the current relationships. It is as much the duty of state legislators to direct economic development, first by standing in leadership to support the compacts negotiated "in good faith". It is then essential for public administrators to ensure that public policy both minimizes unintended consequences and fulfills the missions expressed publicly. 
Inter-governmental relationships are based on the relationships that administrators build. Administrators can foster an atmosphere whereby competitors for resources see one another not purely as adversaries but as collaborators, which can help all competitors reach their potential together. Intergovernmental relationships, not defined by winners at the expense of losers, where administrators and community leaders can navigate the competition more as a relationship of dominos, finding ways whereby they can roll success to the next ripple in the development pond, would prove beneficial.

This atmosphere cannot come about without effort. Those working in the public sector need to be knowledgeable of the populations that they serve, if they are to serve them well. This also points to the need for journalists to understand the environment they report about.

In an age where the President of the United States chants "fake news" to crowds, journalists need to evaluate their role in misinformation. A review of the practice of news stories that no longer give information alone but frame that information in a way as to project opinion, needs to happen. Unless journalists understand the subject matter in total, they do a disservice to those who read their articles and form opinions based on such misinformation. Many of the news stories relating to Native American issues occur in incomplete bits and pieces, which continues to create biased opinions. People with these incorrect assumptions then work within the public sector where they do not understand the tribal governments' goals, so it is no wonder that the outcome is less than desirable. 
In fact, all governments, not only tribal governments, are exempt from income tax. Misunderstanding and alienation of Native American populations by the media is partially due to misleading headlines. It would not surprise anyone that the State of Florida does not pay income tax for any funds generated by business type functions like the Florida Turnpike or turnpike concessions agreements or Florida Lottery, but articles that imply that the Miccosukee government benefits from a special treatment of not paying taxes are misleading. Similarly, an article with the headline, "Despite its wealth, the tribe continues to get lots of federal help" is deceptive (Kestin, Franceschina, \& Maines, 2007). All state and local governments receive funds in the form of grants. A quick review of the 2017 Comprehensive Annual Financial Report indicates, under revenue which Florida received from the federal government: grants and donations amounting to $\$ 22,415,000$ for the general fund; $\$ 164,519,000$ for environment, recreation, and conservation; $\$ 2,125,543,000$ for public education, and $\$ 21,283,955,000$ for health and family services. The failure of journalists to know the topic when writing an article allows for the justification of the berating of news organizations. News organizations alienate the very populations that they rely upon for their existence through this type of "news" reporting. Often referred to as the fourth pillar of democracy or government, the media functions as a "watchdog" on government for the benefit of those governed. To meet the function of the fourth pillar of government, the media must be knowledgeable about the topics they write about, with a critical eye toward bias. 


\section{Summary}

Chapter 6 focused on the inter-governmental relationships between the Seminole Tribe and the Miccosukee Tribe and the local, state, and federal governments. The decimation of Native American tribal governments when reviewing Native American economic development deserves consideration. The expectation that the tribal governments can contort their functions more rapidly than the US government should be revised, if we are to be fair in assessing economic development. Finally, all public administrators including the Bureau of Indian Affairs should advocate for the populations that they serve. The BIA administrators in advocating for tribal governments could serve as a bridge between the US government and the tribal governments. This would require that the Bureau of Indian Affairs understand the goals of the tribal governments, which requires respectful and sincere communication between the BIA and the tribal governments that they serve. The Bureau of Indian Affairs has a mission statement of "enhancing" the quality of life, "promote" economic opportunity, and "protect and improve" the trust assets of American Indians, Indian tribes and Alaska Natives. Understanding historical improprieties can provide knowledge needed to develop empathy in dealing with tribal governments. Distrust in government has grown among all populations over the last $50-60$ years; these examples lay the groundwork for understanding the distrust and perceived unfair treatment experienced by Native American populations.

The focus has highlighted major cases involving the Seminole and Miccosukee tribal governments and the inter-governmental influences that they 
have experienced. The tribal governments have experiences that are unique to them and cannot be compared to any other minority's experience because of the individuality. H.R.4863 asserts that, at a minimum, the Miccosukee tribal government believes that the inter-governmental relationship could improve from changes and suggested a pilot program to effect improvements they felt valid. The suggestion that the Miccosukee tribal government communicate directly with the State Department rather than the BIA under the Department of Interior suggests that in doing so the US may be more understanding of Miccosukee sovereignty. Communication via the State Department may create more productive dialogue and policy development due to the consistency of respectful communication previously practiced by the State Department in discussions with foreign state governments. The idea of respectful communication should not be dependent on what department a tribal government is communicating with, though the public administrator is the reflection of their organization. If government organizations want to enhance their ability to gain cooperation and enhance the public perception, respectful communication with any citizen would be a good place to start and may go a long way in shattering the image of a cold and uncaring government.

As climate change comes with a heavy warning for Florida in particular, as possibly the first state affected, with Traditional Environmental Knowledge (TEK) of the tribal citizens and research facilities abundant in Florida, perhaps working together can save both Native and non-Native populations from avoidable difficulties. 
Chapter 7 considers tribal governmental factors that may affect economic development. Understanding tribal governance viewpoints of sustainability is of significance. The chapter analyzes the Seminole and Miccosukee tribal governments for current economic hindrances or support for tribal members in developing their personal entrepreneurial endeavors. Both tribes have a limited number of members, ensuring that the communities recognize one another regardless of context. My concern for their anonymity was most significant during these interviews. In interviewing non-native individuals that work with tribal governments, a consistent concern that suggested an atmosphere of conspiracy existed, a belief that disruptions in communications, if speaking by telephone, indicated that conversations about Native American issues were subject to scrutiny by US officials. Though these felt like the musings of paranoid individuals, dismissing the accusations because I had not shared the experiences could have equally negative consequences. Interviewees sharing their perspectives was the goal. Animosity affecting people who have experienced suppression through racism, real or perceived, is understandable. 


\section{CHAPTER 7: TRIBAL GOVERNMENTAL FACTORS}

\section{Introduction}

All U.S. governments have similar governing bodies, and most states have similarities to the federal government in having an executive, legislative, and judicial branch. State constitutions outline the unique qualities of their populations as well. Since tribal governments existed prior to the U.S., they too have similarities and unique qualities. As demanded by the Bureau of Indian Affairs, federally recognized tribes must have a tribal constitution. Both the Miccosukee and Seminole tribes have constitutions with the leadership of a tribal council led by elected members. Each tribe is self-determining, and as such this is not a determination of success or lack thereof, since the tribe itself defines success. By aligning the tribal governments, their unique qualities and focus on selfdetermination are clear.

To recap, tribal businesses in general serve the community, much like US governmental agencies. Rather than serve the community by taxing their citizens and providing services with the tax funds, tribal governments create businesses where member employment or patronizing the business generate profit. Governmental services consume profits. Health, education, community centers, libraries, museums, hospitals, police, and fire departments are all supported with the income generated through tribal businesses. When the tribal businesses pay the employees, tribal or non-tribal members, taxes apply, and the individuals must pay the taxes, not to the tribal governments but to the US Federal 
government. Where sustainable economic priorities were reviewed under tribal businesses, this chapter focuses on the tribal government itself.

There is a distinction between the Seminole Tribe of Florida and the Seminole Tribe of Florida, Inc. While the Seminole Tribe of Florida created a constitution and bylaws to set up US recognition of the Seminole Tribe, they also set out Articles of Incorporation for the expressed intent of economic development. A tribal council heads the Seminole Tribe of Florida. The tribal council is a lawmaking body which delivers governmental services. The Seminole Tribe of Florida, Inc. is a section 17 federally chartered LLC created to handle all business activity. Both the Board of Directors and Tribal Council are five-member panels. The board of directors and the tribal council share two members. The President of the Board of Directors serves as the Vice Chairman of the Council and the Chairman of the Council is the Vice President of the Board of Directors. The tribal members share equally in ownership of the tribal corporation. Interviews conducted are with individual members of the Seminole Tribe of Florida. They share their thoughts as individuals and not as spokespersons for the Seminole Tribe of Florida.

The section 17 designation allows the tribal government to enter into contracts without following technical requirements whereby business agreements must meet approval by the Bureau of Indian Affairs to confirm the agreement. The requirement to confirm approval in treaties began as protection for Indigenous tribes believing that, "Indians, either individually or collectively, were 
incapable of protecting themselves from fraud in the conduct of their economic affairs" (S. Rep. No. 106-150, 1999).

A tribal council leads The Miccosukee Tribe of Indians of Florida and the same tribal council leads the Miccosukee Business Council in handling all their economic development. The Miccosukee Tribe of Indians of Florida does not have a section 17 federally chartered LLC.

\subsection{Miccosukee Tribal Government}

\section{Figure 7.1 Depiction of Miccosukee Government Structure}

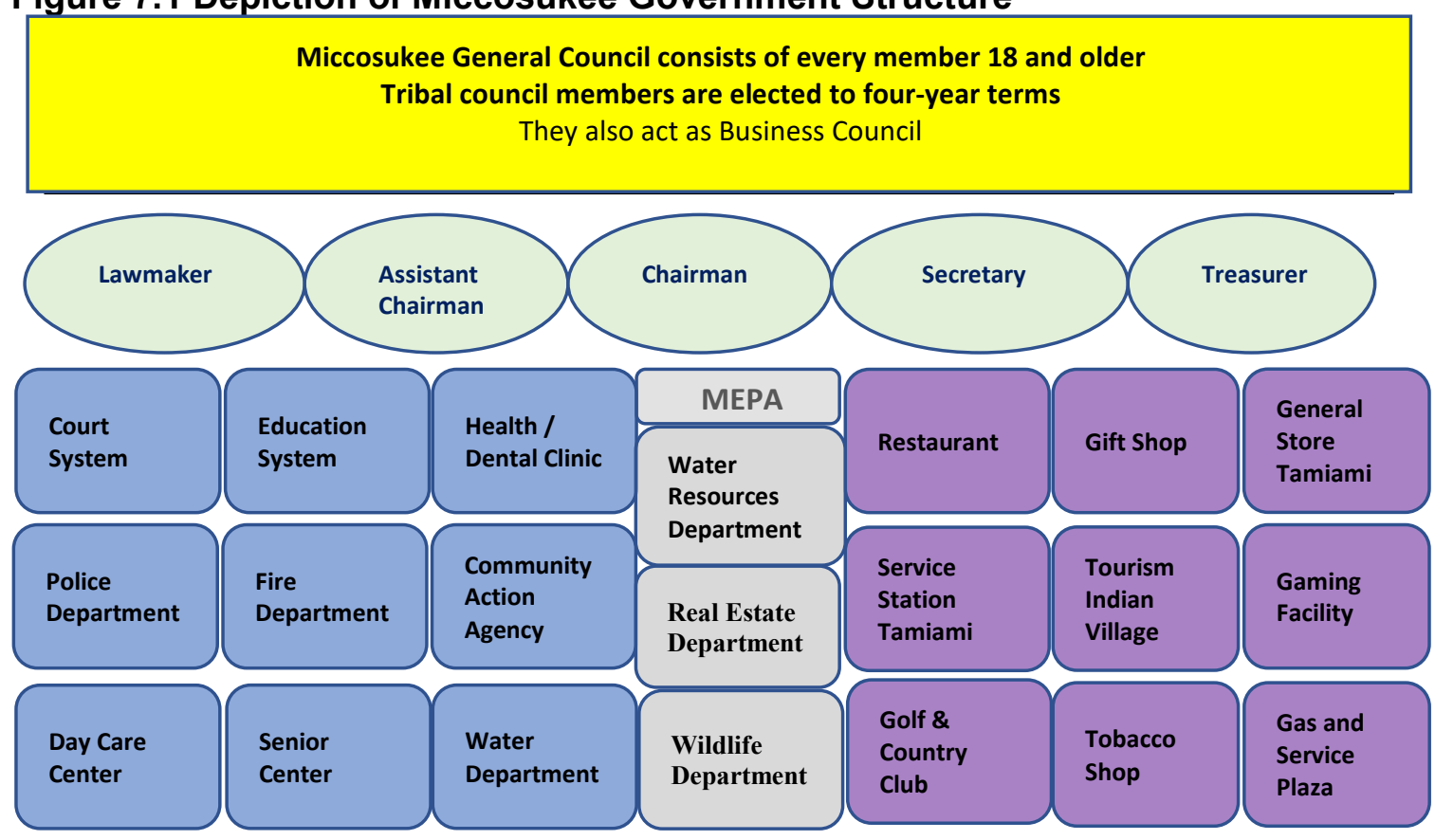

Source: Author's depiction

Figure 7.1 is a graphic depiction of the Miccosukee tribal government. This model is to aid in understanding the unique qualities and size of the government. The Tribal Council consists of five members elected to office, usually in November of election year, serving four-year terms. These members are referred to as the Tribal Business Council distinct from the Tribal General Council which 
consists of all tribal members 18 years of age and older. The elected council oversees the day to day operations when the general council is not in session. They oversee the normal government service departments depicted in blue. I have placed this water resource department in the center, reflecting the central concern for the Miccosukee people. The head of the Department of Water Resources department is Truman (Gene) Duncan.

The Miccosukee tribe is much smaller in membership and reservation land, at least occupiable reservation land which runs along the Tamiami Trail, than most other tribes. Privately organized homes are set back a few yards from the highway, within privacy fencing.

A council member offered to explain their views on the tax dispute discussed in Chapter 6.1. He asked if I was married, to which I responded in the affirmative. "How long did it take for you to figure out what upset each of you and how to avoid upsetting one another?", he asked. I thought about it and explained that we had been friends and had discussed many things for an exceptionally long time before getting married, so I do not think that it took us very long. He went on, "Do you think it would be different in an arranged marriage, where you meet and are married, and then learn about each other?" Of course, I had to admit that under those circumstances, it would be harder to get to know one another. He agreed and explained that this is the relationship they have with the US government. It was a forced marriage, and they are still getting to know one another. I was fascinated by the simplicity, yet thoroughness with which this comparison evoked understanding. 


\section{$\underline{\text { Miccosukee Governmental Departments }}$}

The following departments are like typical government departments, with a few unique qualities specific to Miccosukee government. The governmental businesses generate the funding to run the governmental departments. Though tribal courts have been in existence for centuries, their jurisdiction is restricted to reservation lands. The Miccosukee employ members within their government support staff and employ non-members as well to direct services such as fire and police protection. An assigned general council member listed with the Florida Department of Transportation (DOT) coordinates when contacted by the Florida DOT about environmental management, cultural resource management, and historic preservation.

Miccosukee Courts

Miccosukee courts are available for accused Miccosukee members when the occurrence is on tribal land. Unlike U.S. law, many tribal court systems, including Miccosukee, are more focused on healing the issue rather than punishing. These goals are often reflected in mainstream society, as being lenient or as protecting the tribal member. However, the fact is that it is much easier to apply the law evenly if it is not focused on punishment, to address individual problems. The Miccosukee courts oversee criminal, civil, juvenile, and traffic violations of tribal ordinances. The court building is near the administration building on Tamiami Trail. Court is heard the first Monday of every month. The judge, not necessarily trained in law, is very knowledgeable about cultural customs while addressing legal issues. The tribal attorney sits next to the judge, 
acting as legal counsel. Because the goal is healing and not punishment, there is no Miccosukee prosecutor, like there are in U.S. courts, where the prosecutor serves as the presenter of the case for the 'people'. If called for, a special prosecutor can be assigned by the judge. The Miccosukee do not believe in jails, so there isn't one on the reservation, but the Miccosukee court can sentence someone to Miami-Dade jail for up to one year. The difference between jail and prison is the one-year marker. Frequently, a person in U.S. court is sentenced to a year and a day, which places them in prison rather than jail.

\section{Miccosukee Police}

Figure 7.2 Photo of Buffalo Tiger and Don Osceola

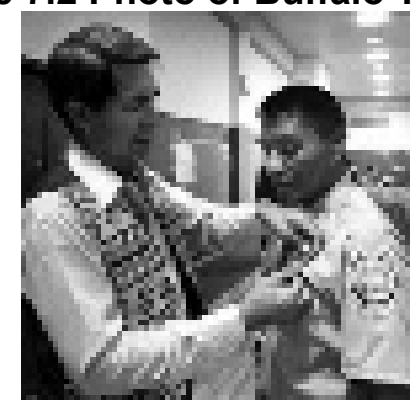

Source: 4mage Number PR23440, Print Collections, State Archives of Florida

An article carrying a photo of Buffalo Tiger pinning a badge on Dan Osceola (Figure 7.2) at Miami-Dade Community College (MDCC) in 1977 states that developing a police department and other aspects of their community infrastructure were the main efforts of the Miccosukee petition to the Department of the Interior to assume direct control over BIA programs run on tribal land in 1971. Interviewee M3 advised that the Miccosukee are culturally not able to 
serve as part of their tribal law enforcement because it is against their culture to point a firearm at another Miccosukee member. Though the Native American population is the among the smallest in numbers of the population, they are the largest demographic to serve in the US military, M3 advised that serving in the military is dissimilar to law enforcement. Confronting another Miccosukee member while fighting in war is not likely. This distinction could place the Miccosukee members at the mercy of outside and biased individuals if they did not control their own services. News articles have publicly discussed the difficulty in retaining law enforcement officers over the years. Some of the issues may be cultural in nature. Some officers felt that detaining non-Native populations for charges in a traditional court, while Native populations are charged in tribal court, shows leniency towards tribal members. Raised with an understanding of U.S. courts and seeing tribal courts as awarding lesser punishment than that handed down to non-natives in city/county/state court systems is unfamiliar to nonmember populations. Unless steps are taken to increase cultural competency, it is often difficult to work in an organization that is unfamiliar in culture. The new police leadership is looking into correcting any misperceptions.

\section{Miccosukee Education}

A Bureau of Indian Affairs August 2016 report states that the Miccosukee educational system made outstanding progress by successfully developing its own accountability system, exempting them from the BIE single accountability system. In traditional Miccosukee ground breaking fashion, they were the first to be granted a waiver from the No Child Left Behind Act (NCLB) on June 1, 2015. 
Interviewee M1 stated that the need for emphasis on teaching in the traditional culture and traditional language made the NCLB Act incompatible with Miccosukee education.

Much like the traditional end of school year field day at mainstream schools, the Miccosukee Tribe provides the older, middle and high school age members with a fun filled day on the reservation. I had the experience of engaging with the Miccosukee members while helping with their school celebration. This celebration happens around October/November of the year. The Miccosukee tribe with Florida Fish and Wildlife Conservation Commission (FWC) set up and teach archery and loaning the equipment for the day so the young men could experience the activity. While tradition forbids the young ladies from taking part in archery, they had fun canoeing along the canal. The teachers and volunteers set up strength and endurance races. The mothers served an abundance of food for everyone. Photos from the event are below as Figure 7.3. The FWC personnel trained the volunteers to help in training the young men and that was another experience with outreach. FWC personnel had been working with Miccosukee members prior to this event. Several conversations about how the rangers and members had worked together tracking and finding pythons in the Everglades occurred. The pythons wreak havoc on the indigenous wildlife, particularly alligators. The FWC rangers displayed respect to Miccosukee members while giving positive experiences. I was surprised when the young men took breaks and the mothers and aunts would also take lessons showing that the cultural restriction pertained only to young ladies and not once they are adults. 
Figure 7.3. FFWL personnel training volunteers and signage at school event
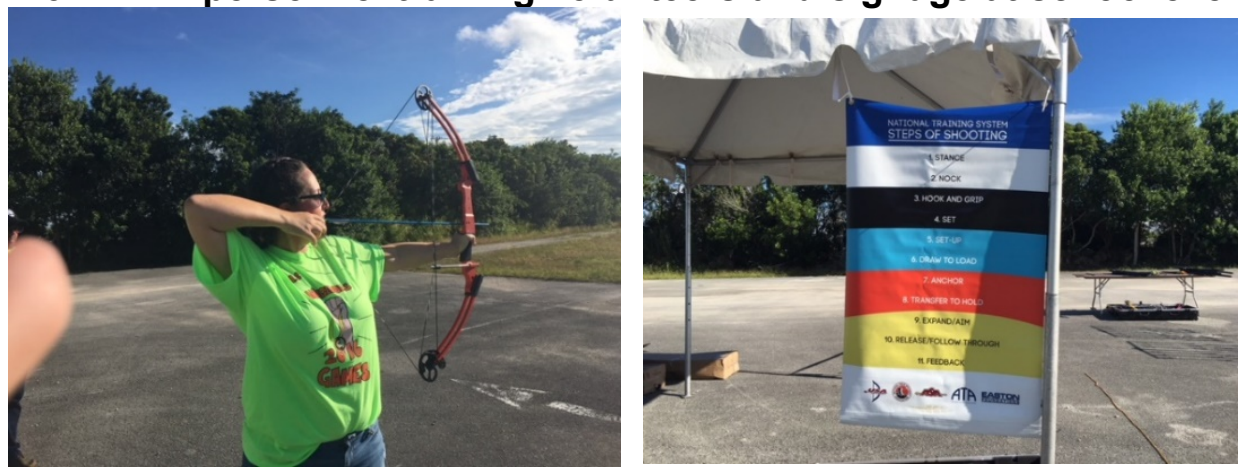

$\underline{\text { Miccosukee Health }}$

The health and dental clinic are the first services that the Miccosukees took control of from the Bureau of Indian Affairs through litigation. Annually, the Miccosukee Tribe Health and Wellness Department, in partnership with Whole Foods market, offers free health screenings, healthy eating information and other health related services to men in the surrounding South Florida community at the Miccosukee Administration Building.

Miccosukee Day Care Center

Early child development is the focus for the Miccosukee day care. The principal of the Miccosukee Indian School is also the contact for the day care center. No further information was made available.

\section{Miccosukee Senior Care}

As with many of the tribal communities, there is great love and admiration for the elderly. Not every elder attends the Senior Care, but often members would step into the senior center for a short visit with an elder, a grandparent, aunt or uncle. There was no further information provided.

\section{Miccosukee Community Action Agency}


The Miccosukee do not have an emergency management department. That is not to say that they do not address emergencies, such as hurricane related preparations or recovery, but they do not employ a department director or staff to address those issues. As the need arises, they address these concerns as a tribe, together.

\section{Miccosukee Water Resources Department}

The Miccosukee do have their own department of water resources with an environmental director. As you may recall, the Miccosukee make enormous efforts to reach out to environmentalists and outside members of the community on issues that affect all communities in Florida. Water concerns appear to be the largest of their anxieties. Much of the Miccosukee efforts are to ensure that their homeland areas are free of pollutants and that development does not destroy natural habitats for indigenous wildlife. Using their water management department, the Miccosukee Tribe checks their water quality independent of the South Florida Water Management. As detailed earlier, the Miccosukee have set the legal standard for the phosphorus at 10 parts per billion (ppb). The South Florida Water Management director said that the water has reached the designated level. The map below (Figure 7.4) provided by the Miccosukee water management shows where they have sampled on the reservation and why the Miccosukee dispute South Florida Water Management District's report that $90 \%$ of the Everglades is clean and pollution free. The Miccosukee Tribe has litigated the pollution issue of the Everglades several times and they have endured threats of land seizure by then Florida Governor (Bush) in 2003. The Miccosukee 
depend on the land and water around them to sustain their cultural existence. As you can see in the map, the circles are the sampling areas. The colors show the level of phosphorus parts per billion gallons. As shown, the areas within the Miccosukee reservation reflect the higher levels shown by the yellows, orange, and red. The Miccosukee members aver that this problem is the result of the water not flowing through the Everglades as nature intended. Because the water has no flow, areas where the current bends collect the pollutants and the water flow is unable to dilute them. Despite the common knowledge that the problem is manmade, decades of brainstorming and funding have failed to reach a solution thus far. 
Figure 7.4 Everglades Water Sample Map

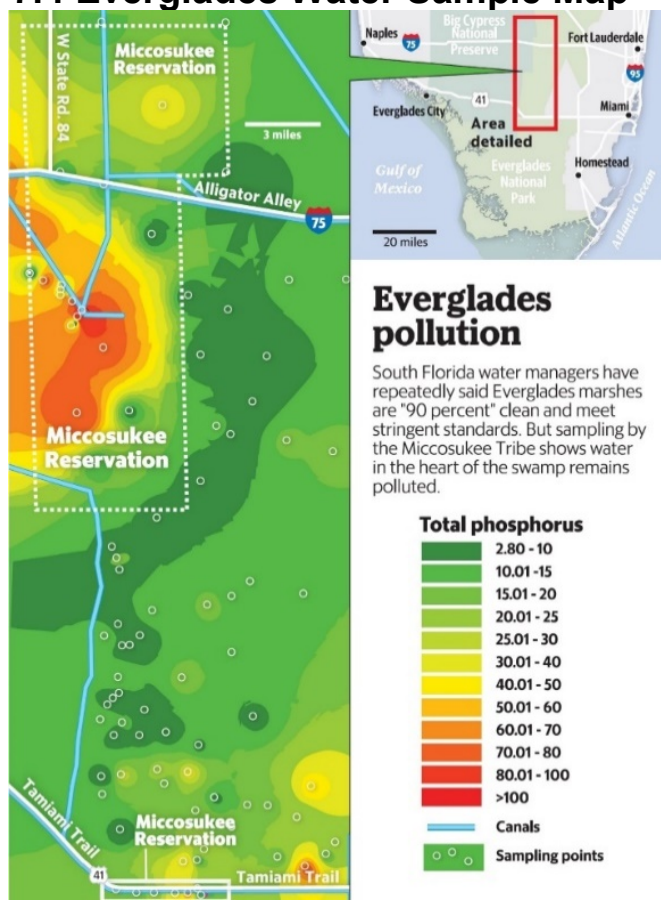

Source: Miccosukee Tribe

\section{Water Department}

The Water Department handles the tribal water tower and water connections to the homes.

\section{$\underline{\text { Real Estate Department }}$}

The Real Estate Department manages land resources, land leasing, etc. Any contracts for development or extraction would be handled by this department.

\section{Wildlife Department}

The Wildlife Department oversees wildlife on the reservation land and lease lands. 
Together, the Water Resources, Wildlife and Real Estate Departments make up the Miccosukee Tribe's Environmental Protection Agency, MEPA. The directors of these departments, along with three Miccosukee member advisors, make up the Miccosukee Environmental Committee.

\section{Economic Development and Training}

The U.S. Department of Labor Native American Employment and Training Council (NAETC) lists recent law graduates and Miccosukee tribal members as the Workforce Innovation and Opportunity Act (WIOA) council until May 2018, which has not been updated. The Council was established in Sept 2015. While serving on the NAETC, M10 also served on the Florida Governor's Council on Indian Affairs, Inc. He is now studying for the bar and working as a law clerk for a local Coral Gables Florida firm. He has the distinction of being the first Law Graduate of the Miccosukee Tribe, graduating from Miami University in 2018. Love the Everglades Non-profit

Created by a couple of fellows, one of which is a Miccosukee Tribe member, the organization coordinates events like Everglades clean-ups and the annual Love the Everglades symposium, which Florida International University has hosted portions of in the past. The picture below (Figure 7.5) shows a group of volunteers, following one of the Everglades clean-ups. 
Figure 7.5 Photo of Volunteering with Love the Everglades cleanup

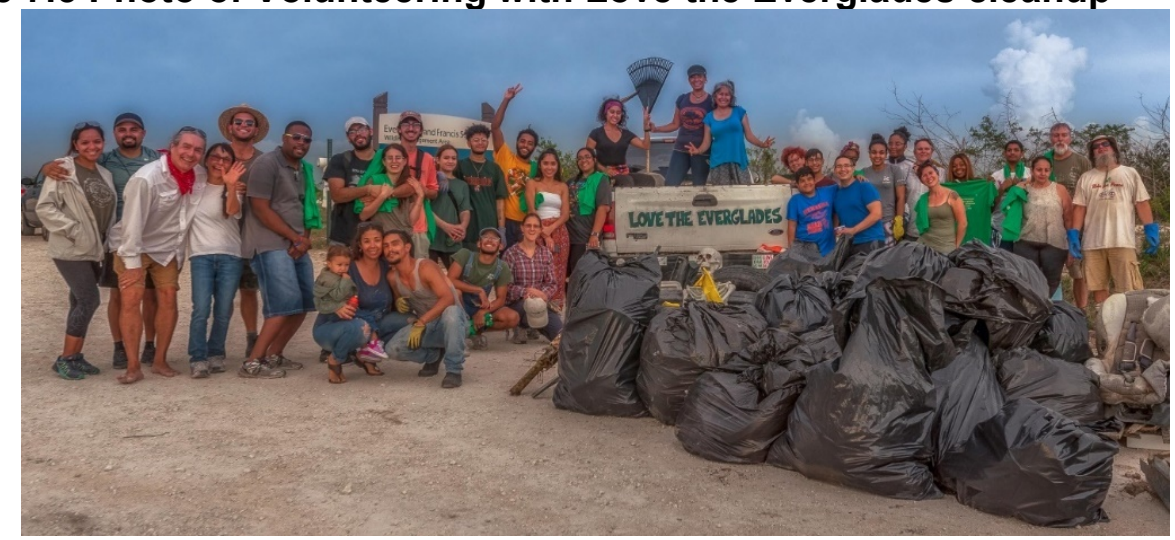

Source: Love the Everglades volunteer

\subsection{Seminole Tribal Government}

The Seminole tribal government is highly active in pointing out that they employ more than two thousand non-Indians paying more than $\$ 3.5$ million in payroll taxes annually. They additionally buy more than $\$ 24$ million dollars in goods and services from Florida vendors per year. Because the reservations are non-contiguous, addressing the issues at the various reservations is dissimilar to most other non-federal governments. Because of the size of the government, the sophistication alone is impressive, but the vast growth of the government and the services offered are a testament to the dedication they have in caring for their members. The members also say that though the tribal council and Board of Directors are accessible, the massive efforts have also introduced a level of bureaucracy that is no more welcome in the Seminole government than in U.S. government. Over 300 members of the Seminole Tribe are employed by the Tribal government. In Figure 7.6 (previous page) I have outlined the major 
activities graphically to help with the understanding developed during this

research.

Figure 7.6 Graphic Depiction of Seminole Government Structure

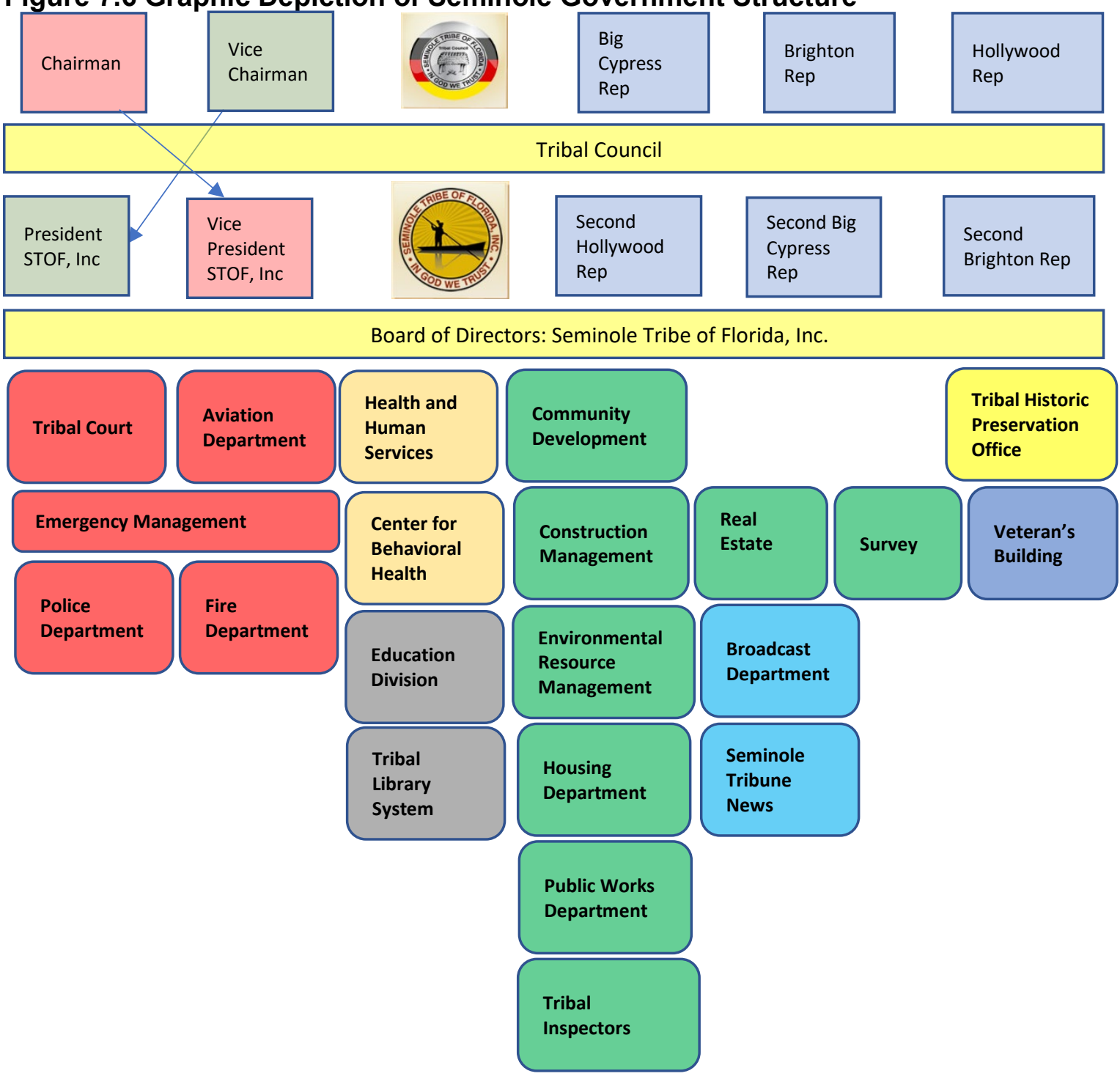

Source: Author's depiction

\section{$\underline{\text { Tribal Courts }}$}

The Seminole Tribal Courts consist of both trial and appellate courts.

Seminole courts are available for Seminole members. The Seminole courts are 
also more focused on healing than punishing. The Seminole courts oversee civil, juvenile, and traffic violations of tribal ordinances and codes. The Seminole court is at the administrative building in Hollywood, suite 320 . Seminole trial court consists of a Chief Judge and two associate judges, and all must be Seminole Tribal members. One of the three judges hear the filed cases. The trial judge also has an adviser to aid in matters of law and procedure. If the tribal member is not happy with the outcome there is an appeals court; however, the appeals court's ruling is final. Law training is not necessarily part of the tribal judges' skills, but they are very knowledgeable about Seminole tribal customs in addressing legal issues. The Seminole Tribe does have a jail, referred to as a lockup, which is in Hollywood FL. The lockup is a holding area. The area holds arrestees for a maximum for 72 hours. They are transferred to the nearest county jail, usually Broward County jail, if they are held longer than 72 hours.

When it comes to family court for Seminole tribal members, the U.S. $17^{\text {th }}$ Circuit Court has taken the lead in implementing the Indian Child Welfare Act (ICWA) of 1978 which stipulates that in case of "any State court proceedings for the foster care placement of, or termination of parental rights to, an Indian child not domiciled or residing within the reservation of the Indian child's tribe, the court, in the absence of good cause to the contrary, shall transfer such proceeding to the jurisdiction of the tribe" (H.R. Res. P.L. 95-608, 1978). The Seminole Tribal administration reached out to the $17^{\text {th }}$ Circuit Court and working together they have set up cooperation whereby attorneys can train to serve in the Seminole Tribal Court. They become a member of the Seminole Tribe of Florida 
Bar Association and serve the Seminole people in family proceedings. Court cases involving tribal members are transferred to the Seminole tribal court where the cases are heard.

\section{Police Department}

Due to the various reservations, the police department consists of South and North Commands. The North Command covers the Tampa / Brighton / Ft. Pierce reservations. The Ft. Pierce reservation is the result of a fifty-acre land purchase in 1995. The Seminole Tribe requested the BIA to transfer the land to the Federal trust for them. The reservation is home to Seminole Tribe descendants who lived in that area before the U.S. government entities in the area existed. The South Command covers the Hollywood/Coconut Creek / Big Cypress / Immokalee reservations.

The department also has two bureaus, operations and support services. Operations Bureau consists of the patrol division on all the locations. Support services is a collection of the administrative units such as professional standards and training, logistics division, human resources, records, budget, criminal and investigations division, including internal affairs and emergency management.

The criminal and investigations division has the criminal investigations unit, the threat response unit, youth services, and property and evidence unit. The youth services consist of the explorer's program, which several local police departments in South Florida have, to help relationships between law enforcement and community youth. The program allows a closer relationship, with officers allowing the youth to both see that officers are people that have 
chosen law enforcement as a career and that as the youth become older, they might choose the same field for themselves. This is succession planning as well as relationship building. Youth services also covers the topic of juvenile crimes. The unit works within the community to identify truancy issues, crime trends, and carry out investigations.

The state of Florida certifies all police officers, which is true of any police department within Florida, and Seminole Police meet the requirements set up by the Florida Department of Law Enforcement. Former Florida certification is one of the criteria, as Seminole Police rarely sponsor an individual through the police academy for the Seminole Police Department.

\section{Fire Department}

The fire department has locations on each reservation. The Fire Chiefs' Association of Broward County lists them as members of the mutual aid agreement, meaning that they support other fire departments as requested within Broward County, their main fire station in Broward County being the Hollywood Florida entity on State Road 7 hear the Hard Rock Casino. The fire chief has been with them for over ten years, with a rich background in fire department leadership, serving for Fort Lauderdale FL and Davie FL prior to Seminole Tribe. There are fire stations in Big Cypress (2002), Brighton (2005), Hollywood (2007), and Immokalee (2017).

\section{Emergency Management}

The Seminole Emergency Management Division falls under the Seminole Police Department. As the Seminole reservations are widely dispersed, they 
have an emergency notification system allowing tribal members to enroll in the system, so that during emergencies they can be notified by cell phone and email, keeping them always informed. The hazards that the Emergency Management Division focuses upon are any boil water alerts, drought, extreme temperatures, flooding, lighting strike issues, tornadoes, tropical cyclones, wildfires, or other severe weather. They have a Facebook presence as well. For evacuation preparation, they list both the on reservation and local county shelters for each reservation location. This certainly shows the inter-governmental cooperation that is increasingly relevant for all communities and governments. Generators and generator services are a telephone call away, with reminders of generator safety, including when and when not to run them due to carbon monoxide issues. A disaster hotline for tribal members and employees is also available.

\section{Aviation Department}

Due to the vast area required to be covered, the Seminole Tribal Government uses air travel, which is additionally used for fire suppression and response for both tribal and non-tribal communities. Working with the Bureau of Indian Affairs, the Seminole Tribe created a fire suppression and response program, allowing its extension beyond the reservation jurisdictions. They have a tribal airstrip (red dot in Figure 7.7) on Big Cypress reservation near the Ah-TahThi-Ki Museum (blue dot). 
Figure 7.7 Aerial View of Seminole Aviation Strip

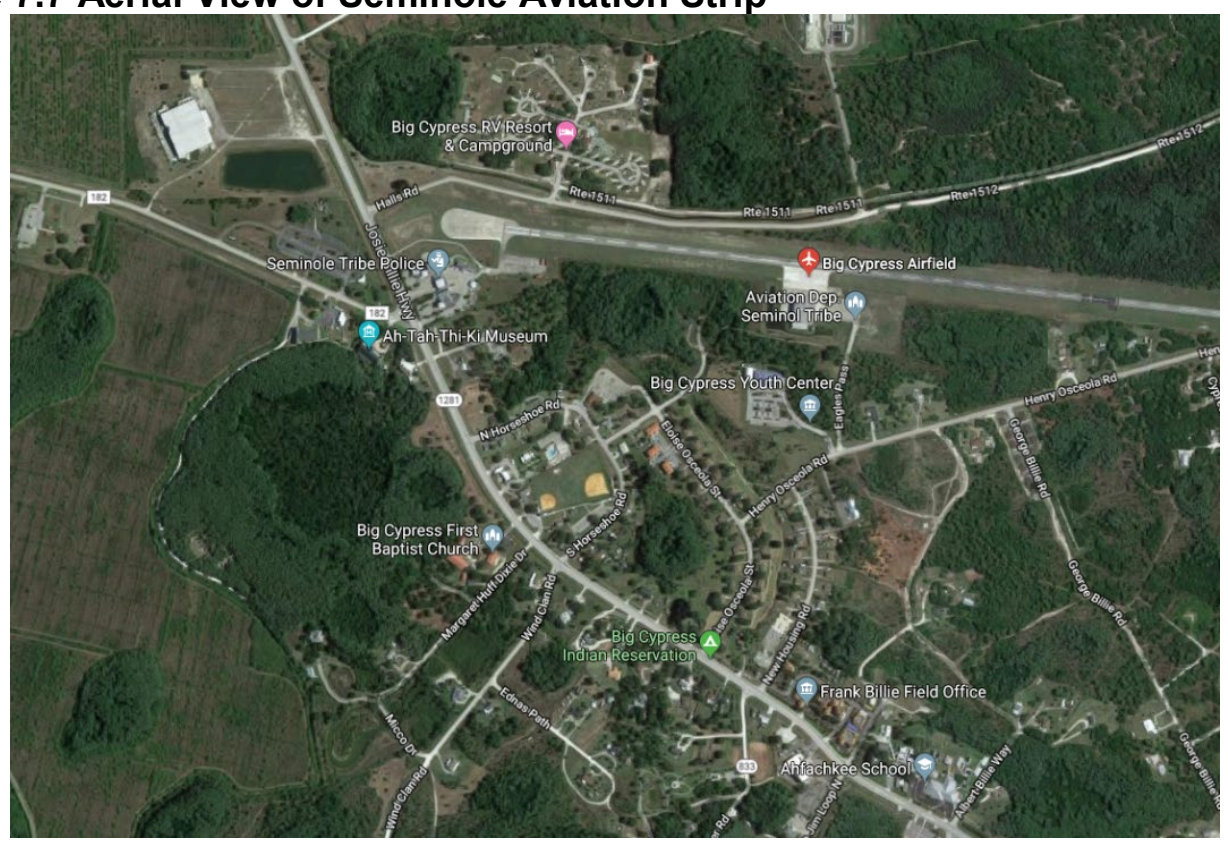

Source: Google Earth

The Aviation Department supports the Police department for security and traffic control. Though the Seminole Tribe has a fleet of aircraft, the exact types and numbers were not shared. They also have a crew of pilots, and at this time (7/2018) are seeking another pilot to direct maintenance testing; the candidate should hold over 3,000 hours of flight time with 1,500 in multi-engine jet, 500 hours in turbine planes and international operating experience. In March 2018 they were seeking a helicopter pilot. It should be noted that the first "additional qualification" in both positions is, "Interest in the Seminole Tribe of Florida history, culture and operations". Clearly, this is an issue of importance, stated before any aviation knowledge. 


\section{$\underline{\text { Health and Human Services }}$}

Health clinics are on Hollywood, Big Cypress, Brighton, and Immokalee reservations. They also have a Pharmacy and a health office in Tampa. They give medical, dental, and pharmacy services, and include health education and nutrition services as well.

Unique to the Health and Human title, environmental health includes covering food safety, animal control, mosquito and infections control, air quality, and pool / spa inspection.

\section{Center for Behavioral Health}

Separate from the Health and Human services, the Center for behavioral health addresses mental health and substance abuse treatment as well as traumatic brain injuries and bariatric evaluation and weight loss. Treatment of emotional and physical well-being is the goal.

\section{Education Division}

The design of the educational system is meant to encourage giving members skills toward successful careers while also strengthening their tribal knowledge and identity. The K-12 students can choose either public or private schools. If the student and their family choose to go to a private school, they can receive a tribal scholarship but must keep good grades. They have advisers on every reservation to help families make the choice. The application incorporates a parental release so consent for the tribal governance can monitor school grades. 
The Billy L Cypress scholarship for higher education, which can be used toward any two or four-year undergraduate or graduate degree, as well as trade school or technical college, is available for members. The scholarship can also help with continuing education or general education for adults. The Seminole education division also sponsors educational trips to colleges for high school students, and annual trips to Tallahassee FL and Washington DC to see government in action. There is a cultural exchange program with trips to other tribes to learn and experience other cultures. Trips called 'Close Up' take students to Washington DC to watch U.S. government in action, annually.

For professional development they also have a Work Experience Program (WEP) which places tribal members in a type of paid internship within a participating tribal organization. This program is open to both students studying a field or an individual as an 'on the job training'. They also have a tutoring program available for those students who need help, including homework help. One of the advantages of having help during their educational development years is that the students don't hesitate to ask for help going forward. While volunteering at the 2018 pow-wow event, one of the young ladies was having difficulty in her algebra homework. As soon as she learned that I teach, she reached out for help. She was very bright and after a couple of problems worked out together, she had no problem finishing her homework. I was happy to help and even more happy to see that she had a genuine interest in learning the material. 


\section{Library System}

The Seminole Tribe Library system is under the Center for Student Success and Services (CSSS). They provide educational and cultural activities for Seminole Tribe students. They have libraries on the Immokalee, Brighton, Big Cypress, and Hollywood reservations.

\section{Community Development}

Community planning and development is the largest of their agencies. Community development includes everything from building to leasing and public works delivery. Strategic land use that is sustainable while preserving the Seminole Tribe way of life is their mission. They coordinate with the Environmental Resources Management Department, Public Works, and the Tribal Historic Preservation office as well as other tribal entities and follow the federal regulatory process for trust lands.

\section{$\underline{\text { Construction Management }}$}

Construction management handles both commercial and residential capital projects. The commercial project managers oversee all construction, both commercial and residential. The residential team works with the tribal members to help design and budget based on the members' needs and wants. They assist with design, bidding, and selecting the contractor.

\section{Environmental Resource Management}

The Environmental Resource management group works to protect the ecosystem on the Seminole lands. This division was created in 1987. They have implemented the Clean Water Act within the Seminole Tribe lands with water 
quality monitoring for the Big Cypress reservation and are developing standards for the other reservations. Big Cypress land is part of the Everglades restoration area. They have developed spill prevention plans for above ground storage tanks and removal programs for underground storage.

This division also addresses Brownfield response for development, redevelopment, or expansion where hazardous substances, pollutants, or contaminates might be. The U.S. Environment Protection Agency (EPA) coordinates with them as well.

In 1989 the Seminole Tribe set up the Seminole Water Commission, with representation from all reservations. Together they set rules to protect the surface waters within the reservations. The Water Rights Compact is part of the guidelines that the commission uses.

\section{$\underline{\text { Housing Department }}$}

The housing department offers basic home repair for tribal members both on the reservation and in the surrounding communities. Whether it be electrical, plumbing, or $\mathrm{A} / \mathrm{C}$ and appliances, the tribal members feel that they can trust the work and they are just a call away. There is someone on every reservation to help. Members' Housing also covers housing insurance. Amerind Insurance covers the homes on the reservation under the Housing Department. Amerind is a Native American Tribe owned company founded in New Mexico. When a hurricane threatens the reservation, shutters (unless the home has impact windows) and generators are installed on the reservation homes. They take care 
of the elderly and members with special needs first. The Real Estate and Surveying departments support the housing department.

\section{$\underline{\text { Real Estate }}$}

The Seminole Tribe owns and has interests in both trust and non-trust lands. They have ordinances and regulations for occupancy and the use of lands that they hold and/or control. In following the ordinances that they have adopted, every person or entity using or occupying tribal land must first have a permit, lease, or other formal authorization. They have over 1,000 leases, permits, or authorizations for the various uses on the tribal lands. The real estate service division manages owned, non-trust property, including the leasing and property maintenance.

\section{Surveying}

This department does boundary and topographical surveys. They handle the construction site stakeouts, and elevation certificates. They determine property boundaries and record survey measurements. They create topographic and contour maps of surveyed land. They also provide advice to the engineers and architects working with the Seminole Tribe.

\section{Public Works}

This department administers the construction, operation, and maintenance of the Seminole Tribe infrastructure for water, waste water and distribution collection systems with facilities and sanitation services. The industry has recognized their water treatment facilities as one of the best (Figure 7.8). They use a reverse osmosis (RO) drinking water plant and the wastewater reclamation 
plant has undergone recent expansions. Florida does not regulate the plant, they run it as if it were. The Seminole Tribe compares the U.S. EPA regulation with the State and decides which is the more stringent regulation. The more stringent regulation would become their governing regulation. In addition to their routine water treatment activity, crews go out to help the emergency management division, picking up items that could become dangerous and distributing information to the tribal residents if a hurricane threatens the reservation. The crews also do community outreach, going to juvenile detention centers and giving career day presentations, encouraging juveniles to get their high school diploma or GED so that they can become an operator, since the Seminole Tribe is a founding member of United South and Eastern Tribes (USET), which has a licensing program for water and wastewater operators. USET water and wastewater training programs often use the Hollywood plants to train other tribes' operators. 
Figure 7.8 Aerial view of Seminole Water plant

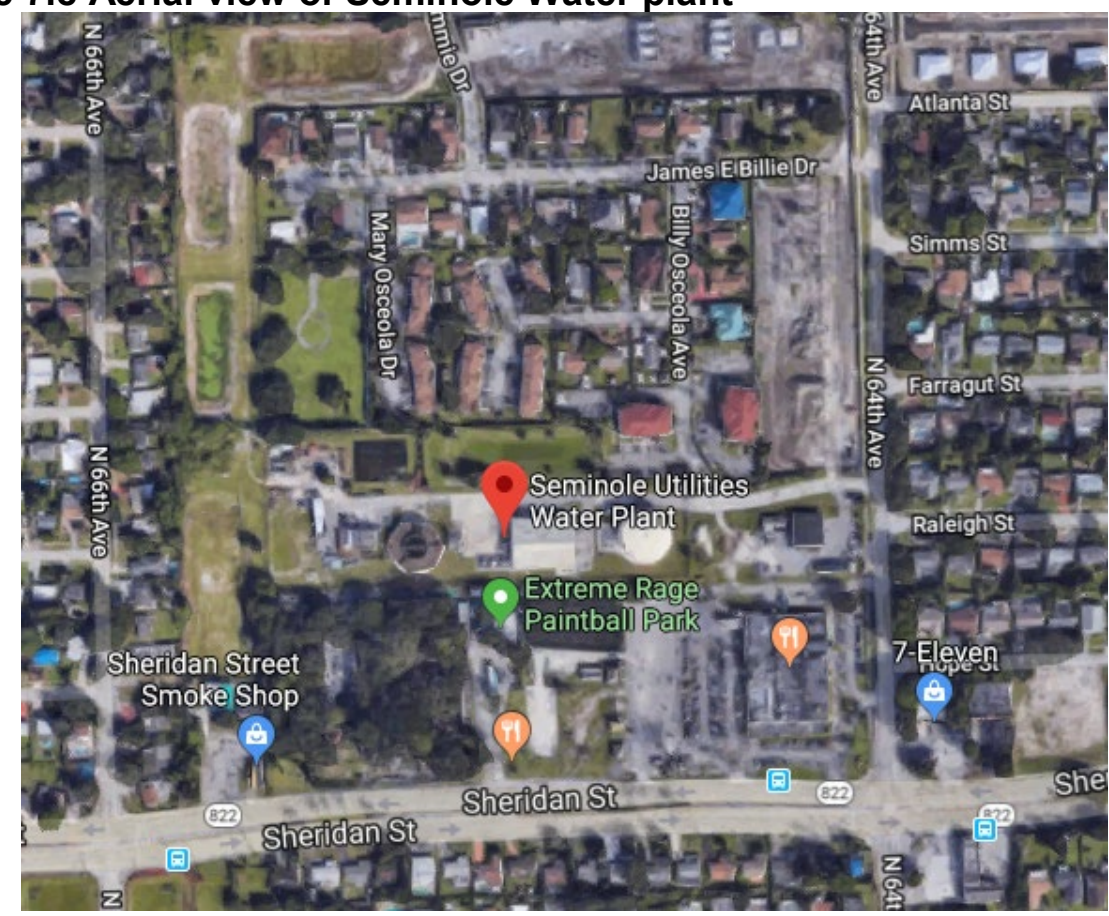

Source: Google Maps

\section{$\underline{\text { Tribal Inspections Department }}$}

The building inspections department covers new and renovated

properties, both residential and commercial. The Seminole Tribe has modeled their building codes after the Florida Building Code. They use the wind-borne debris region map to determine design and construction. To receive plan approval, the builder sends two sets of plans, signed by an architect or engineer registered in Florida, to the department. Once approved, they return one set for construction, while the department files the other set. 


\section{$\underline{\text { Historic Preservation }}$}

The Historic Preservation Division has five sections, archaeometry, architectural history, collections, compliance review, and tribal archeology. Together they canvas areas. They properly handle the collected items, preserving them for the collective knowledge about anything that has to do with the Seminole reservation lands. Tribal members work with non-members to ensure that they learn, understand, and share the needed skills. The Historic Preservation Officer also oversees the Ah-Tah-Thi-Ki museum.

\section{$\underline{\text { Veterans }}$}

It is not surprising, since the Native American is the largest demographic serving in the military, that the Seminole Tribe holds an extraordinary amount of appreciation for the Seminole Veterans. The characteristics of the Veterans Building are quite remarkable. The building is in the shape of a five-pointed star. Each point symbolizes the five branches of the US Armed Forces; Army, Navy, Air Force, Marines, and Coast Guard. The Seminoles used the same material, from the same quarry, used for the Smithsonian Museum of the American Indian in Washington D.C., i.e., Minnesota dolomite limestone. In keeping with the Florida Seminole respect for the cypress, cypress wood covers the ceiling in the auditorium. The aerial view of the building on the Brighton Reservation (Figure 7.9). 
Figure 7.9 Aerial View of Seminole Veterans Building

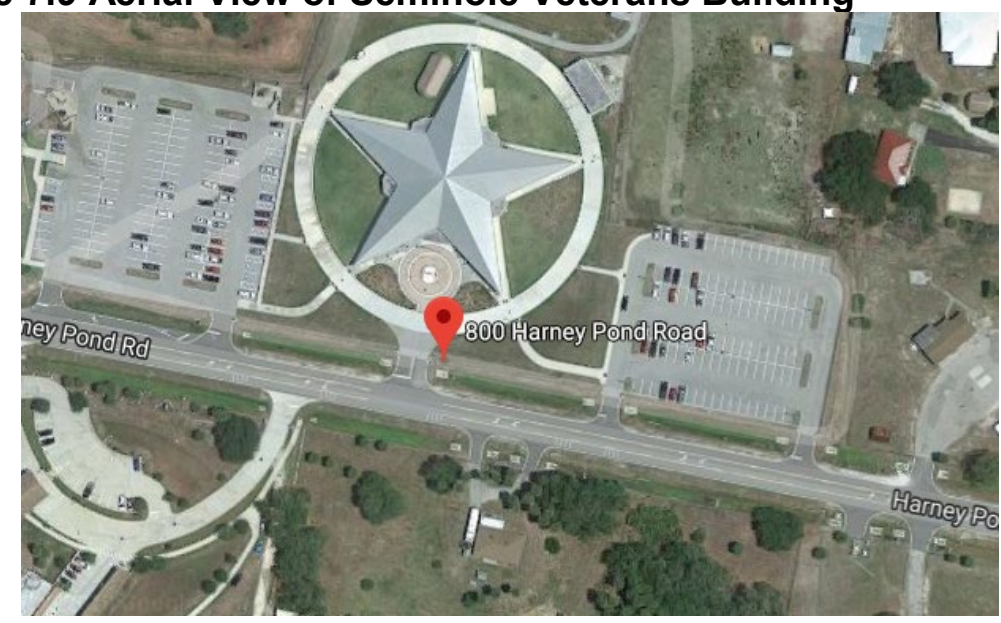

Source: Google Maps

One of the projects that the Seminole Tribe supports is the Native American Indian Memorial initiative. Many people are aware of the U.S. Marine Corps War Memorial in Washington D.C.; more commonly known as the Iwo Jima Memorial, because it is one of the more recognizable memorials (Figures 7.10-12). The memorial sits outside of the Arlington National Cemetery in Arlington, Virginia. What most people do not know is that there is a Native American among the group of six men raising that flag. The six men were Ira Hayes, Franklin Sousley, Harold Shultsz, Harlon Block, Rene Gagnon, and Michal Srank. Ira Hayes was a Native American from the Pima tribe, an Arizona reservation. The Native American Veterans Memorial Initiative is to place a memorial honoring the Native American veterans on the National Mall. 
Figures 7.10-7.12 Iwo Jima Memorial
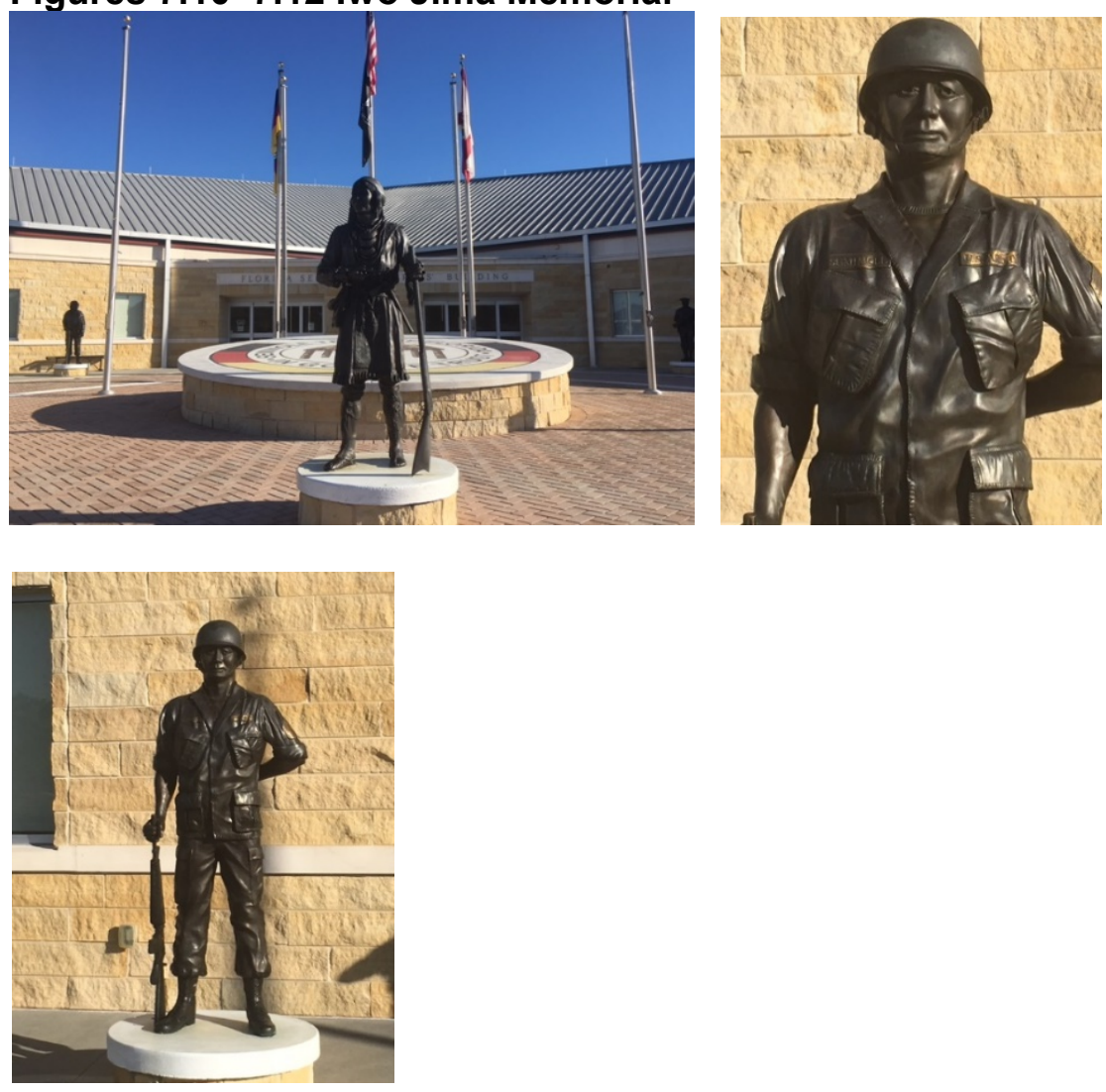

The art of design is nothing new for Seminole people. Artistry and creativity are a natural content of character, reinforced by tradition. One of the entries for the National Native American Veterans Memorial was a collaboration Seminole/Ponca design, according to the office of Tribal Government relations within the US Department of Veterans Affairs. Figure 7.13 below is design entry which was submitted for consideration. 
Figure 7.13 Seminole/Ponca entry

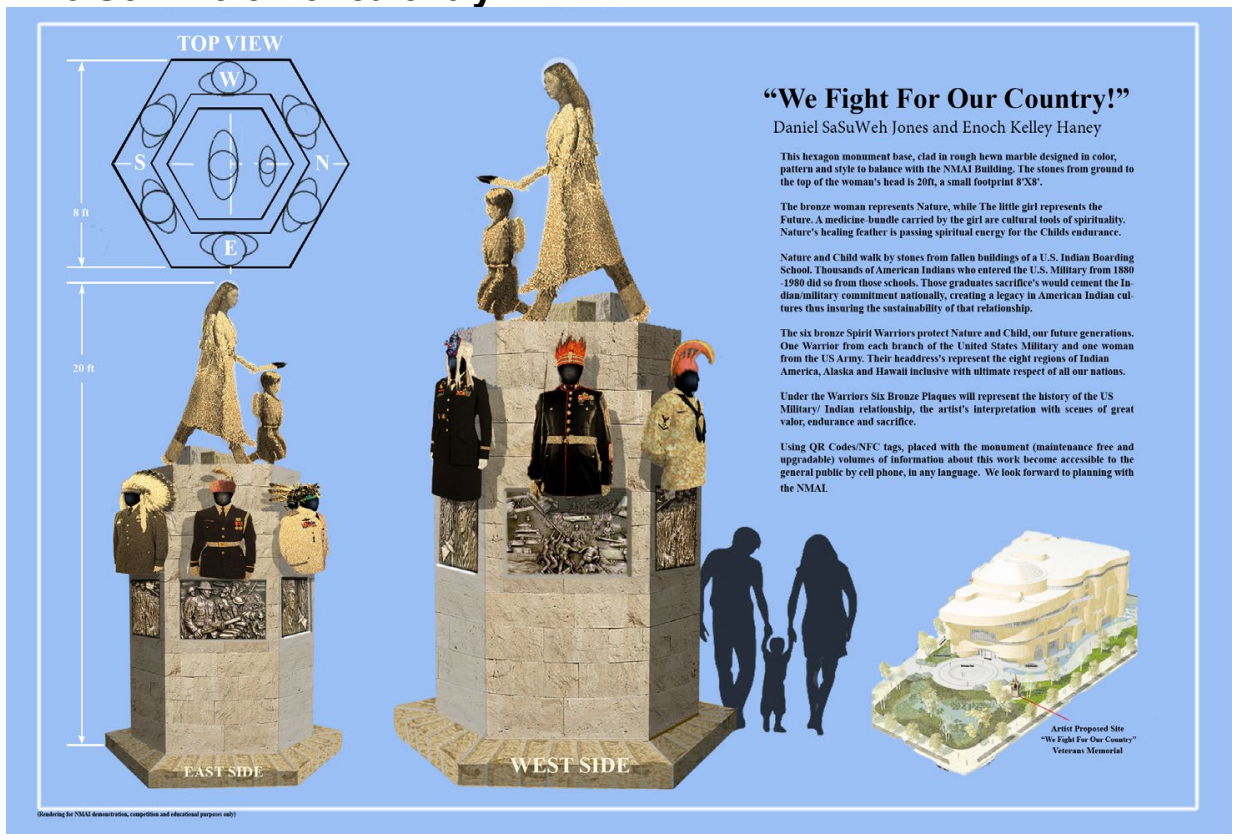

Source: http://nmai.si.edu/sites/1/files/nnavm/Jones-Haney-Stage-I.pdf

The Seminole/Ponca entry was one of the final four selections. In June 2018, the winning choice was "Warriors' Circle of Honor". The groundbreaking ceremony is slated for September 2019, and the dedication on Veteran's Day 2020. The rendering, done by Skyline Ink, (Figure 7.14).

\section{Summary}

This chapter reviews the governments of the Miccosukee and Seminole Tribes. It is easy to see why the Seminole members feel that the level of bureaucracy has developed in the Seminole Tribal government, considering that its size and sophistication rivals that of many municipalities in Florida. 
Figure 7.14 Winning entry depiction

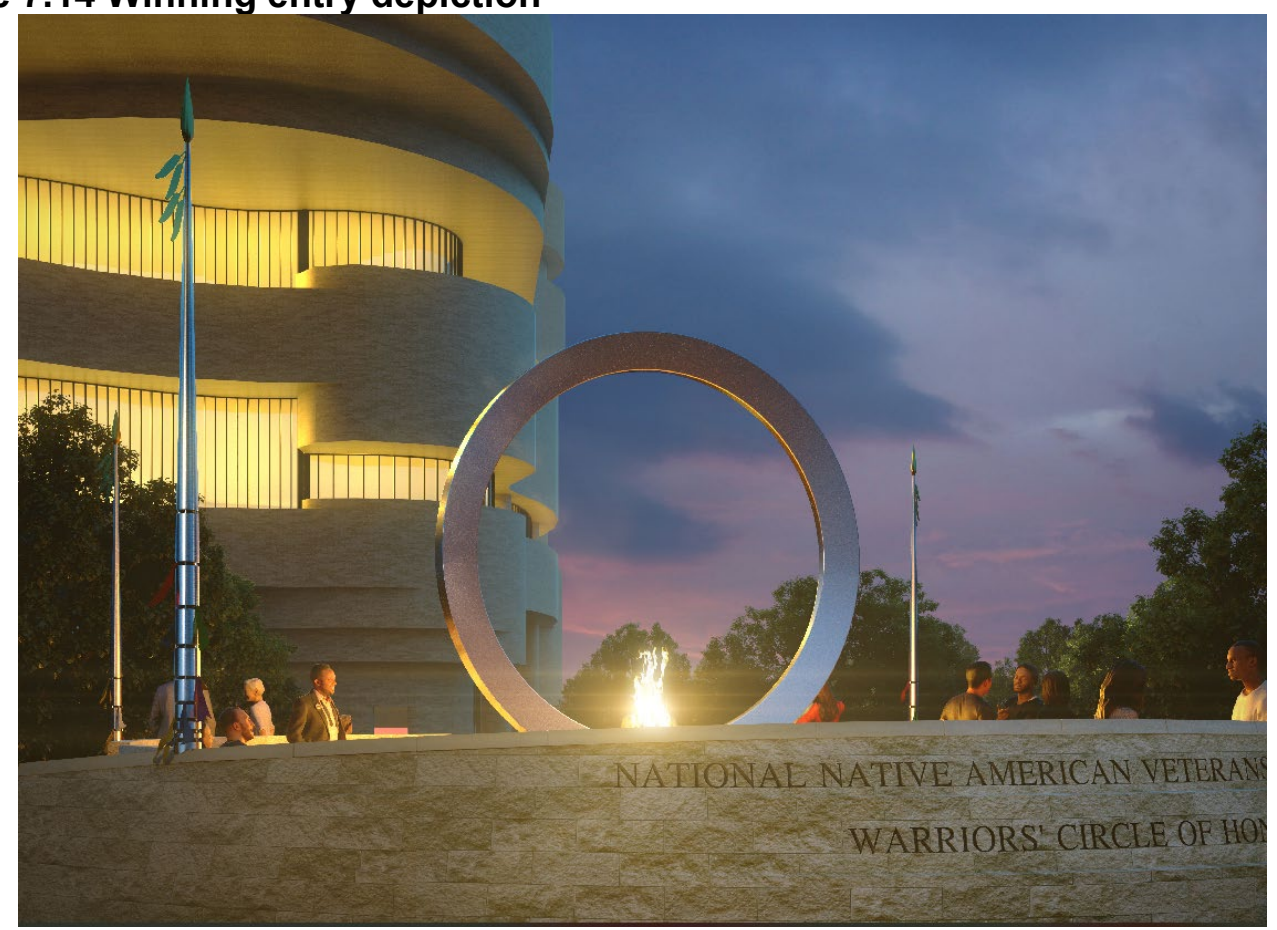

Source: National Museum of the American Indian

While interviewing S2, upon asking if there were lessons learned by the Seminole and Miccosukee experiences that may help struggling reservations enhance their economic development, he said that I had not asked the milliondollar question. When asked what question he was referring to, he suggested, "So what is so different about the Seminoles"? He explained that one of the reasons that the Seminole have been successful is because they never accept that they cannot affect their future with their own ideas. He clarified, saying that when tribal governments want to try something that has not been done before, the U.S. government often tells the tribal governments that they cannot do the project, or if it has been started, they cannot continue the project. In the case of 
other tribal governments, they accept that answer and stop trying to make the change. In the case of the Seminole, they will ask why not, and make every effort to continue in the desired direction until the Seminoles decide that there is a valid reason why the idea will not work. When and if they make that determination, they will then accept the outcome. If there is no good reason, they will do whatever is necessary to ensure that the endeavor continues, regardless of predetermined prohibitions. He guessed that for the reservations under formal treaties that were denied tribal self-determination for so long or with the time spent accepting no as an answer, it has become the norm to accept that outcome. There are restrictions within the treaties that confine the tribal governments in distress from even proposing economic advancements. S2 was quite clear that whatever the issues are, the Seminole do not accept answers from other authorities that negatively affect them. S2's conversation clarified that time may have contributed to the problem when reservation economic development lags.

The Seminole Tribe invests in outside organizations as well. As discussed earlier, they have decided that reaching out to collaborate with both Native American businesses and small farmers makes sense, giving them the opportunity to help while investing in organizations that support cultural integrity and beliefs. Additionally, they are shareholders in other Native American endeavors, such as the Native American Bank, which helps other tribal entities develop housing and build their communities. 
Chapter 7 reviewed the distinctions between the Seminole and Miccosukee tribal governments. The progress of each of these tribal entities hinges on a mixture of cultural distinctions, the level of desired tradition, and experience. The Seminole's progressive characteristics contrasting with the Miccosukee desire to hold traditions closer is not a factor of success but distinguishes what each has determined is the right level of progress enabling their definition of success. Though the Seminole Tribe has a cultural sensitivity to the effects of economic development, especially resource extraction, understanding and negotiating is based on real needs and wants.

Chapter 8 revisits the themes, clarifying how this research not only answers the research questions but prioritizes the knowledge gained while doing this research. Tribal members also shared ideas that the Miccosukee and Seminole tribal governments can consider. 


\section{CHAPTER 8: CONCLUSION AND RECOMMENDATIONS}

\section{Introduction}

Throughout this dissertation, in trying to understand the priorities of economic development for the Seminole Tribe of Florida and the Miccosukee Tribe of Indians of Florida, there have been examples of policy provided by both the tribal governments and the various U.S. governments. The Seminole and Miccosukee Tribes give examples that compliment as well as contrast with each other in many ways. Both are examples of self-determination, albeit different in pace and/or goals. The Seminole Tribe desires to support sovereignty while being functional in the mainstream economy. The Miccosukee Tribe desires to support sovereignty but would like to keep itself private. The Miccosukee Tribe is more interested in keeping their existence in the Everglades and keeping the Everglades in a way that the creator or Breath-maker will be pleased with.

This last part is significant in that the Miccosukee Tribe, through the media, has tried to explain the relationship with the Everglades by sharing their belief that Breath-maker gave the tribe the directive of protecting the Everglades. Just as Christians believe God will return to Earth to judge, the Miccosukee Tribe also believes that Breath-maker will return to judge, but their success is related to their protection of the Everglades, among other things.

Knowing the respective positions of both tribal governments and the U.S. governments, effective policy making can be both challenging and innovative. In looking at policy development and outcomes, along with political effects, public administration addresses public policy from development to implementation. It is 
the public administrator who ensures, in designing policy, that the wishes of the majority do not impinge upon the rights of the minority.

Serving the public interest is often expressed as public policy. It is the translation of what some believe is the popular will of the people into actions to carry out that will. As public administrators we must determine if policies are serving public interest. We know that if the majority view is taken to be the 'will' of the people, we must hear the will of the minority too. The entire population expressing a will or even a majority is a simplistic notion. Believing that translating that will into policy can address the competing concerns for limited resources is also naive, but with that in mind, public policy should ensure that unintended consequences do not place burdens on those precluded from having or unable to have their will heard.

U.S. economic policy analyzes several aspects before determining any policy change. Regulation is a balance of insuring safety for the citizens while minimizing burden on business. Taxation of business and individuals must insure that necessary and desired services can be provided, while also not burdening either causing a decline in confidence with regard to the economy. Healthcare is part of the U.S. economy and therefore must consider those costs that are provided both by the government and paid for through private insurance. Loss of any of these services can prove to be a deterrent to economic stability and growth. State and local governments make similar decisions in attempting to create a positive environment for business and talented workers, while also insuring that revenues match services that governments are responsible for 
providing. In areas needing economic growth, policy focuses on economic development. When a region would like to increase business investment, they often offer a predetermined period of tax reduction or elimination. Care must be taken in doing this, as the services such as drainage, water, roads etc. must still be paid for. Tax reduction or elimination places the burden elsewhere, on other business or individuals for the determined period. There is also no guarantee that the business will not move to the next generous area once they have met the end of the tax relief period.

To further the goal, the department of labor offers investment funds to improve infrastructure, while state and local governments give the incentives for business relocation or development. With reservation land, there are greater restrictions. The offer could be in the form of a favorable lease, if attracting businesses to reservation land is the goal. Factors to consider when thinking of economic development for a U.S. reservation, is that the reservation land is highly limited. Add to that limitation what seems like a constant threat of more land loss, as the U.S. federal government has taken additional land away from the reservations over the years. Utilizing reservation land for limited housing while adding land through purchase has been the observed usage for the Miccosukee and Seminole Tribes.

The characteristics of the tribal governments are all unique based on the tribe and their needs. While mainstream populations make decisions to incorporate or to have a strong mayor or council form of government, the choices and needs for tribal government are different. Not just different from mainstream 
governance, but also different from other tribal governments as well. If working within tribal governments or working with them, this uniqueness needs to be understood by the administrator. Public administrators cannot presume to know the inner workings of the tribal government like they might understand local government structures. Only after caring enough to understand the structure and what the tribal culture is, can the public administrator do their best to fulfill the administrative needs of the tribal government or the needs of a responsive outside agency working with the tribal government.

\subsection{Theme 1: Native Americans should be able to determine their own economic development priorities}

The participants of this study expressed many purposes for economic development, but for the Miccosukee and Seminole Tribes of Florida, the priority is clear. The ability to support sovereignty outweighed any other purpose, the authority to live in a way that honors both their heritage and self-determination.

The policies of the tribal governments may often mirror those of the nonNative American governments, but policy design and implementation is in response to an issue or to address the needs of the population. Just as each state needs to address the conditions of their environment, the tribal governments likewise address their unique concerns. Federal policies also place limitations on both state and tribal governments. What is unique are the needs and techniques used to meet those needs. Because tribal governments begin policy development from different points in both time and condition, and understanding the issues tribal governments are addressing, blanket policies are 
insufficient. Since the tribal governments need to ensure that they protect their sovereignty, they must develop their own policies. Any help would have to be in an advocacy role. Considering the possibility that $\mathbf{S} 2$ was correct, showing that self-determination has not previously meant finding a way to implement a desired policy, but rather to provide authorization, advocacy must manifest as support and helpful recommendations. Naturally, the most effective advocates are also those of Native American experience or heritage, along with policy knowledge with a positive advocacy outlook.

S2 stated that the Seminole have hired people to count and report things to those who need numbers, "but the fact is that every Seminole that wants a job, has a job". This is no different than the way the US counts employment or unemployment. The US bureau of labor and statistics does not count people who are not looking for work or who are retired because they are not part of the workforce.

The participants of this study listed the purposes for economic development as different methods to reach goals: educating themselves and others, being self-sufficient, giving their families what they need. Several participants spoke of self-sufficiency. There were suggestions that the ability to produce and sell food in a grocery/farmer's hybrid market was of interest. The current trend toward local harvesting even for prestigious restaurants supports this idea. The suggestion was a type of hybrid or cooperative. This would bring outside money into the reservation area and allow those that like to grow food to sell to one another. The Seminole economic development director suggested that 
feasibility studies showed insufficient population for a supermarket. The Seminole Tribe is also very conscious of the effect they have on economic conditions for Florida as a whole. As expressed earlier, the Seminole Tribe has cited several benefits that the gambling compact gives, including the money spent in the Florida economy.

There are programs as suggested, designed to help Native American entrepreneurship listed through the Department of Economic Development (DED) as Native American Foreign Trade Zones. One of the predominant programs is the establishment of a Foreign Trade Zone (FTZ) within US Native American reservations. DED defines a Foreign Trade Zone as "a designated geographical area where foreign and domestic goods are treated, for tax and tariff purposes, as if they never entered the United States". Goods shipped into the foreign trade zone then shipped to another foreign trade zone (reservation) or another country are exempt from U.S. duty (tariff). Goods entering the U.S. can significantly reduce duty in a foreign trade zone. Industries currently using this type of Foreign Trade Zone include petroleum, automotive, consumer electronics, and pharmaceuticals.

These zones are subject to federal, state, and local laws and regulations, and therefore Foreign Trade Zones cannot trade copyright, trademark, or patented items. Foreign Trade Zones are also not exclusive to Native American reservations; there are 250 Zones throughout the USA with only five tribal applications, four approved. One tribal application, (Lummi Nation) has had 
approval since 1986; however, none of the tribal Foreign Trade Zones have had any free trade activity yet.

There are currently 21 Foreign Trade Zones in Florida, four with Miami as the port of entry and two with Port Everglades. Since these FTZs are not exclusive to Native American reservations, local impact may be a factor in not using them.

U.S. government departments that work to provide opportunity without consultation with tribal governments cannot be effective. Each tribe, as shown in the cases of the Miccosukees and Seminoles, is unique. The attempt to view them as a monoculture is inappropriate. Each will have their own concerns and requirements that affect self-determination. Community development agencies do not supply the same development in every community. Considerations of location, demographics, environment, etc., are known before development of a plan. This knowledge rests with the tribal population and their elected government.

\subsection{Theme 2: External agencies should be empathetic to Native American economic development priorities}

Some literature, Rodrigues for example, has suggested that the only proper and correct version of policy development or policy implementation is that provided by the U.S. agencies. There is little acknowledgement of economic development of Native American people prior to colonization. This is not just incorrect, but lacks empathy, understanding, and support. Rodrigues points to the tribal council members holding 'menial' jobs at the various tribal businesses, 
expecting other staff to also contribute as needed. This contributed to the characterization of the Miccosukee tribe's inability to implement position classification. While external agencies may believe that the method familiar to them is best practice, the environment is not always similar and may need cultural adaptations. In fact, Rodrigues points out that, culturally, Miccosukee members are unable to judge one another, a point of criticism for position evaluation.

While economic development in the United States has had varying degrees of success, the conditions of Native American reservations have evolved through time and changing circumstances not created by the residents. Applying current economic development structures and requirements negates the respect for the trials endured by those residents and their ancestors. This respect is part of the cultural dynamic that external agencies do not normally consider in interactions. External agencies interacting with Native American reservations would advance their effectiveness by understanding the specific culture of the reservation population with which they are working. The agencies that take the time to support the culturally unique qualities of the population that they are supporting would also encounter less resistance to shared ideas. Outside agencies and imposed policies will ultimately be viewed as a continued assault on tribal sovereignty. 


\subsection{Theme 3: Support tribes to develop their own governance structures appropriate to their economic development priorities}

True support for Native American economic development needs to allow for the development of governance that considers tribal priorities. Defining the implementation regardless of cultural norms defeats the act of self-determination. The economic development itself is more important than the implementation process.

Support needs to be advocacy, with respect for what the various tribes want to try rather than the granting of permission. What works off the reservation may take adaptations to work within reservation environments or with reservation populations. Remote areas in particular may require infrastructure, based on tribal governments wishes.

The Miccosukees and Seminoles have adapted their growth to their own priorities. The economic exchange with surrounding areas has helped local governments and populations. Though both tribes are undergoing growth and development, they offer a record of success to guide other development if cultural differences are minimal. Despite the two tribes being together during their survival, they display variance in governance structures and priorities developed since recognition. The similarities in teaching their history to their children and not accepting limitations on their success have shown that these conditions are a common factor of success.

Tribal governments with prior limits placed on their efforts to try new development or to take self-determining actions need renewed support, which is 
to find ways to carry out efforts rather than impede them. Experience with stockholders who are also stakeholders is rare. Should Elkington be on the right track, suggesting that as these positions meld corporations building partnerships will become more common, those experienced with this environment can offer understanding of doing so successfully. Considering that the Seminoles and Miccosukees are perfect examples of shareholder/stakeholder in one, their views may raise important concepts to consider.

By respecting the tribal government structures, working with tribes may develop cooperation and ease tensions. Though the states and municipalities do not have direct interactions with tribes, state and federal laws require other government agencies to consult with tribal governments when the outside entity is developing or approving plans which could affect the tribal community. There are no barriers preventing county and local municipalities from reaching out to tribal governments. Collier county officials, seen at several Seminole events which took place on the reservation close to them, are building a better relationship with the Seminole tribe. By building the relationship, county officials feel that they can talk to the tribal council more easily and in a less formal way. Sharing ideas can help both entities support their constituents while discovering unique ways to address needs with limited resources. Concerns about land use, water use, and effects of climate change can be addressed using traditional ecological knowledge (TEK) while experience with stakeholder/shareholder knowledge may also prove quite valuable to mainstream economies as well. 


\section{Conclusion}

A major issue that public administration has sought solution to, is the lack of trust in government. There is a palpable distrust, within the Native American reservation communities. Treaties not honored, constant threat to loss of sovereignty and lack of respect, real or perceived, fuels this distrust. Much like the use of states as a testing ground for policy, reservations may be the best place to build trust. If trust can be rebuilt with the Native American population, there is so much that can be done to heal trust relationships and build trust with the general population.

The priorities for the Miccosukee and Seminole were very similar, sustainability centered around their history and culture. Knowing one's own history and having pride in who you are and where you came from has been essential. According to Daniel Sznycer, "the function of pride is to motivate the individual to cultivate traits and pick courses of action that increase others' tendency to value them" (Sznyceret al., 2017, p.1875). As a research participant in this study stated, "unless you know who you are as a member of your tribe, your clan, how can you learn about someone else and how you fit into the world?" Both the Miccosukee and Seminole also expressed the desire to inform mainstream populations of their histories and contributions. The expressed desire to be able to control their own destiny (independence) and being given the respect and recognition as a government and a people caring for their own population (sovereignty). This shared desire includes how communities impact one another within shared environments. These were all high priorities for the 
Miccosukee and Seminole. Addressing these issues when opportunities to interact with tribal governments would be helpful for public administrators.

Mainstream misconceptions about Native American people and their histories, especially if working with other governments, can be frustrating. Public administrators work within shared environments, examples would be regional governments that provide education or water for more than one area working with county or city governments. Similar structures and operational institutions provide those working within these relationships a familiarity. With tribal governments, there is both an opportunity to learn and work together but there is also unfamiliarity. Public administrators must be able to learn and understand cultural differences, as opportunities rather than obstacles.

Governments are increasingly interacting in cooperative and collaborative partnerships. Public Administration should not overlook the opportunity to develop these same relationships with tribal governments, recognizing the tribal government and the shared responsibilities within shared communities and environments. Tribal governments must be given the opportunity to fulfil the needs of their citizens. Tribal governance existed long before the U.S.A. was established so there is a long history of governance, some of which may be different from that which public administration is familiar with, but different is not necessarily wrong.

Forced changes negatively impacted each of the various tribes. Former policies maintained a goal of assimilation into mainstream society. Because of the various attempts to force assimilation, anything short of support and 
facilitation can, and will likely be viewed as continued forced assimilation policies and will be met with resistance.

Public administrators may find that the cooperation and coordination with tribal governments is more substantive than with other inter-governmental experiences. Working on joint projects requires public administrators understand each parties' goals focused on fulfilling the appropriate goals together. Public administrators may find that the experience itself will be inimitable.

Native American should determine their own economic development priorities. Only they know what they are prepared to do, and the way they are willing to do so. Support and facilitation should be the goal of outside agencies. The governance structures appropriate to their own economic development priorities should be supported by those agencies intent on assisting the reservation populations achieve economic success. That success must also be defined by the tribe, not the outside agencies.

Best Practices are only best if they continue to grow and improve the lives of those public administrator's service and impact; as environments change public administration must evolve. We can, and we should build the trust we want to have in our government. 


\section{APPENDIX}

\begin{tabular}{|c|c|c|c|c|c|c|c|c|c|}
\hline \multicolumn{2}{|l|}{ Card Games } & \multicolumn{2}{|c|}{ Class III Slots } & \multicolumn{6}{|c|}{5 Billion Annual Scenario } \\
\hline Year & Monthly & Year & Monthly & $12 \%$ to $2 B$ & $15 \% 2 B-3 B$ & $17.5 \% 3 \mathrm{~B}-3.5 \mathrm{~B}$ & $20 \% 3.5 B-4 B$ & $22.5 \% 4 \mathrm{~B}-4.5 \mathrm{~B}$ & $25 \% 4.5 B$ up \\
\hline 1 & $150,000,000$ & 1 & $12,500,000$ & & & & & & \\
\hline 1 & $150,000,000$ & 1 & $12,500,000$ & & & & & & \\
\hline 1 & $150,000,000$ & 1 & $12,500,000$ & & & & & & \\
\hline 1 & $150,000,000$ & 1 & $12,500,000$ & & & & & & \\
\hline 1 & $150,000,000$ & 1 & $12,500,000$ & & & & & & \\
\hline 1 & $150,000,000$ & 1 & $12,500,000$ & & & & & & \\
\hline 1 & $150,000,000$ & 1 & $12,500,000$ & & & & & & \\
\hline 1 & $150,000,000$ & 1 & $12,500,000$ & & & & & & \\
\hline 1 & $150,000,000$ & 1 & $12,500,000$ & & & & & & \\
\hline 1 & $150,000,000$ & 1 & $12,500,000$ & & & & & & \\
\hline 1 & $150,000,000$ & 1 & $12,500,000$ & & & & & & \\
\hline 1 & $150,000,000$ & 1 & $12,500,000$ & & & & & & \\
\hline 2 & $150,000,000$ & 2 & $70,416,668$ & $20,000,000$ & $15,000,000$ & $7,291,667$ & $8,333,334$ & $9,375,000$ & $10,416,667$ \\
\hline 2 & $150,000,000$ & 2 & $70,416,668$ & $20,000,000$ & $15,000,000$ & $7,291,667$ & $8,333,334$ & $9,375,000$ & $10,416,667$ \\
\hline 2 & $150,000,000$ & 2 & $70,416,668$ & $20,000,000$ & $15,000,000$ & $7,291,667$ & $8,333,334$ & $9,375,000$ & $10,416,667$ \\
\hline 2 & $150,000,000$ & 2 & $70,416,668$ & $20,000,000$ & $15,000,000$ & $7,291,667$ & $8,333,334$ & $9,375,000$ & $10,416,667$ \\
\hline 2 & $150,000,000$ & 2 & $70,416,668$ & $20,000,000$ & $15,000,000$ & $7,291,667$ & $8,333,334$ & $9,375,000$ & $10,416,667$ \\
\hline 2 & $150,000,000$ & 2 & $70,416,668$ & $20,000,000$ & $15,000,000$ & $7,291,667$ & $8,333,334$ & $9,375,000$ & $10,416,667$ \\
\hline 2 & $150,000,000$ & 2 & $70,416,668$ & $20,000,000$ & $15,000,000$ & $7,291,667$ & $8,333,334$ & $9,375,000$ & $10,416,667$ \\
\hline 2 & $150,000,000$ & 2 & $70,416,668$ & $20,000,000$ & $15,000,000$ & $7,291,667$ & $8,333,334$ & $9,375,000$ & $10,416,667$ \\
\hline 2 & $150,000,000$ & 2 & $70,416,668$ & $20,000,000$ & $15,000,000$ & $7,291,667$ & $8,333,334$ & $9,375,000$ & $10,416,667$ \\
\hline 2 & $150,000,000$ & 2 & $70,416,668$ & $20,000,000$ & $15,000,000$ & $7,291,667$ & $8,333,334$ & $9,375,000$ & $10,416,667$ \\
\hline 2 & $150,000,000$ & 2 & $70,416,668$ & $20,000,000$ & $15,000,000$ & $7,291,667$ & $8,333,334$ & $9,375,000$ & $10,416,667$ \\
\hline 2 & $150,000,000$ & 2 & $70,416,668$ & $20,000,000$ & $15,000,000$ & $7,291,667$ & $8,333,334$ & $9,375,000$ & $10,416,667$ \\
\hline 3 & $233,000,000$ & 3 & $70,416,668$ & $20,000,000$ & $15,000,000$ & $7,291,667$ & $8,333,334$ & $9,375,000$ & $10,416,667$ \\
\hline 3 & $233,000,000$ & 3 & $70,416,668$ & $20,000,000$ & $15,000,000$ & $7,291,667$ & $8,333,334$ & $9,375,000$ & $10,416,667$ \\
\hline 3 & $233,000,000$ & 3 & $70,416,668$ & $20,000,000$ & $15,000,000$ & $7,291,667$ & $8,333,334$ & $9,375,000$ & $10,416,667$ \\
\hline 3 & $233,000,000$ & 3 & $70,416,668$ & $20,000,000$ & $15,000,000$ & $7,291,667$ & $8,333,334$ & $9,375,000$ & $10,416,667$ \\
\hline 3 & $233,000,000$ & 3 & $70,416,668$ & $20,000,000$ & $15,000,000$ & $7,291,667$ & $8,333,334$ & $9,375,000$ & $10,416,667$ \\
\hline 3 & $233,000,000$ & 3 & $70,416,668$ & $20,000,000$ & $15,000,000$ & $7,291,667$ & $8,333,334$ & $9,375,000$ & $10,416,667$ \\
\hline 3 & $233,000,000$ & 3 & $70,416,668$ & $20,000,000$ & $15,000,000$ & $7,291,667$ & $8,333,334$ & $9,375,000$ & $10,416,667$ \\
\hline 3 & $233,000,000$ & 3 & $70,416,668$ & $20,000,000$ & $15,000,000$ & $7,291,667$ & $8,333,334$ & $9,375,000$ & $10,416,667$ \\
\hline 3 & $233,000,000$ & 3 & $70,416,668$ & $20,000,000$ & $15,000,000$ & $7,291,667$ & $8,333,334$ & $9,375,000$ & $10,416,667$ \\
\hline 3 & $233,000,000$ & 3 & $70,416,668$ & $20,000,000$ & $15,000,000$ & $7,291,667$ & $8,333,334$ & $9,375,000$ & $10,416,667$ \\
\hline 3 & $233,000,000$ & 3 & $70,416,668$ & $20,000,000$ & $15,000,000$ & $7,291,667$ & $8,333,334$ & $9,375,000$ & $10,416,667$ \\
\hline 3 & $233,000,000$ & 3 & $70,416,668$ & $20,000,000$ & $15,000,000$ & $7,291,667$ & $8,333,334$ & $9,375,000$ & $10,416,667$ \\
\hline 4 & $233,000,000$ & 4 & $70,416,668$ & $20,000,000$ & $15,000,000$ & $7,291,667$ & $8,333,334$ & $9,375,000$ & $10,416,667$ \\
\hline 4 & $233,000,000$ & 4 & $70,416,668$ & $20,000,000$ & $15,000,000$ & $7,291,667$ & $8,333,334$ & $9,375,000$ & $10,416,667$ \\
\hline 4 & $233,000,000$ & 4 & $70,416,668$ & $20,000,000$ & $15,000,000$ & $7,291,667$ & $8,333,334$ & $9,375,000$ & $10,416,667$ \\
\hline 4 & $233,000,000$ & 4 & $70,416,668$ & $20,000,000$ & $15,000,000$ & $7,291,667$ & $8,333,334$ & $9,375,000$ & $10,416,667$ \\
\hline 4 & $233,000,000$ & 4 & $70,416,668$ & $20,000,000$ & $15,000,000$ & $7,291,667$ & $8,333,334$ & $9,375,000$ & $10,416,667$ \\
\hline 4 & $233,000,000$ & 4 & $70,416,668$ & $20,000,000$ & $15,000,000$ & $7,291,667$ & $8,333,334$ & $9,375,000$ & $10,416,667$ \\
\hline 4 & $233,000,000$ & 4 & $70,416,668$ & $20,000,000$ & $15,000,000$ & $7,291,667$ & $8,333,334$ & $9,375,000$ & $10,416,667$ \\
\hline 4 & $233,000,000$ & 4 & $70,416,668$ & $20,000,000$ & $15,000,000$ & $7,291,667$ & $8,333,334$ & $9,375,000$ & $10,416,667$ \\
\hline 4 & $233,000,000$ & 4 & $70,416,668$ & $20,000,000$ & $15,000,000$ & $7,291,667$ & $8,333,334$ & $9,375,000$ & $10,416,667$ \\
\hline 4 & $233,000,000$ & 4 & $70,416,668$ & $20,000,000$ & $15,000,000$ & $7,291,667$ & $8,333,334$ & $9,375,000$ & $10,416,667$ \\
\hline 4 & $233,000,000$ & 4 & $70,416,668$ & $20,000,000$ & $15,000,000$ & $7,291,667$ & $8,333,334$ & $9,375,000$ & $10,416,667$ \\
\hline 4 & $233,000,000$ & 4 & $70,416,668$ & $20,000,000$ & $15,000,000$ & $7,291,667$ & $8,333,334$ & $9,375,000$ & $10,416,667$ \\
\hline 5 & $234,000,000$ & 5 & $70,416,668$ & $20,000,000$ & $15,000,000$ & $7,291,667$ & $8,333,334$ & $9,375,000$ & $10,416,667$ \\
\hline 5 & $234,000,000$ & 5 & $70,416,668$ & $20,000,000$ & $15,000,000$ & $7,291,667$ & $8,333,334$ & $9,375,000$ & $10,416,667$ \\
\hline 5 & $234,000,000$ & 5 & $70,416,668$ & $20,000,000$ & $15,000,000$ & $7,291,667$ & $8,333,334$ & $9,375,000$ & $10,416,667$ \\
\hline 5 & $234,000,000$ & 5 & $70,416,668$ & $20,000,000$ & $15,000,000$ & $7,291,667$ & $8,333,334$ & $9,375,000$ & $10,416,667$ \\
\hline 5 & $234,000,000$ & 5 & $70,416,668$ & $20,000,000$ & $15,000,000$ & $7,291,667$ & $8,333,334$ & $9,375,000$ & $10,416,667$ \\
\hline 5 & $234,000,000$ & 5 & $70,416,668$ & $20,000,000$ & $15,000,000$ & $7,291,667$ & $8,333,334$ & $9,375,000$ & $10,416,667$ \\
\hline 5 & $234,000,000$ & 5 & $70,416,668$ & $20,000,000$ & $15,000,000$ & $7,291,667$ & $8,333,334$ & $9,375,000$ & $10,416,667$ \\
\hline 5 & $234,000,000$ & 5 & $70,416,668$ & $20,000,000$ & $15,000,000$ & $7,291,667$ & $8,333,334$ & $9,375,000$ & $10,416,667$ \\
\hline 5 & $234,000,000$ & 5 & $70,416,668$ & $20,000,000$ & $15,000,000$ & $7,291,667$ & $8,333,334$ & $9,375,000$ & $10,416,667$ \\
\hline 5 & $234,000,000$ & 5 & $70,416,668$ & $20,000,000$ & $15,000,000$ & $7,291,667$ & $8,333,334$ & $9,375,000$ & $10,416,667$ \\
\hline 5 & $234,000,000$ & 5 & $70,416,668$ & $20,000,000$ & $15,000,000$ & $7,291,667$ & $8,333,334$ & $9,375,000$ & $10,416,667$ \\
\hline 5 & $234,000,000$ & 5 & $70,416,668$ & $20,000,000$ & $15,000,000$ & $7,291,667$ & $8,333,334$ & $9,375,000$ & $10,416,667$ \\
\hline SubTotals & $12,000,000,000$ & & $3,530,000,064$ & & & & & & \\
\hline State Revenue Totals & $15,530,000,064$ & & & & & & & & \\
\hline Annual oversight assessment & $1,250,000$ & & & & & & & & \\
\hline Donation to Florida Council & & & & & & & & & \\
\hline Cumpulsive Gambling & $8,750,000$ & & & & & & & & \\
\hline & & & & & & & & & \\
\hline Payment totals & $15,540,000,064$ & & & & & & & & \\
\hline To Local Govn'ts affected & $466,200,002$ & & & & & & & & \\
\hline
\end{tabular}




\section{Adult Verbal Consent}

\section{FIU] UNIVERSITY}

\section{ADULT VERBAL CONSENT TO PARTICIPATE IN A RESEARCH STUDY Economic Development on U.S. Native American Reservations: A case Study of the tribes of Florida}

Hello, my name is Diane Benitez. You were chosen at random to be in a research study about economic development on U.S. Native American reservations. The purpose of this study is to understand the priorities of the Seminole and Miccosukee tribes of Florida. If you decide to be part of this study, you will be one of people in this research study. Participation in this study will take about an hour of your time. If you agree to be in the study, I will ask you to do the following things:

1. If you don't mind I will be using a digital tape recorder to record our conversation, I can type up what is said afterwards.

2. If you would prefer not to be recorded, I can write notes on what is said but I do not want to interrupt our conversation if at all possible

3. If you don't mind, after I type up the conversation, I may have follow-up questions, if I could email or call you with those questions, it would be greatly appreciated.

4. I will give you the chance to read the typed conversation if you would like, just to make sure that we can both see what is captured.

There are no foreseeable risks or benefits to you for participating in this study. It is expected that this study will benefit society by allowing people to understand the priorities that may be different from standard economic development. Some of what I learn may also help other Native American tribes in their efforts in economic development.

There is no cost or payment to you. If you have questions while taking part, please stop me and ask.

You will remain anonymous and your answers are confidential. In any sort of report that might be published, I will not include any information that will make it possible to identify you as a person who provided answers. These research records will be stored securely and only the researcher will have access to the records.

They will be kept in a file which is password protected and no one other than myself will know or have access to that file. I will also use unique identifiers like numbers rather than names in the report.

If you have questions for me after our conversation, you can contact me (Diane Benitez) at 305321-1568 or diane.benitez@gmail.com. 
If you would like to talk with someone about your rights of being a subject in this research study or about ethical issues with this research study, you may contact the FIU Office of Research Integrity by phone at 305-348-2494 or by email at ori@fiu.edu.

Your participation in this research is voluntary. You can refuse to participate or decide to stop at any time. Do you agree to participate in this research? 


\section{References}

2010 Seminole Compact [Compact Agreement]. (2010). Retrieved from My Florida License:

http://www.myfloridalicense.com/dbpr/pmw/documents/2010_CompactSigned1.pdf

Ackerman, S. (2013). Seminole Indian charter school gives students the best of both worlds. Retrieved from

https://www.redefinedonline.org/2013/09/seminole-indian-charter-schoolgives-students-the-best-of-both-worlds/

Agranoff, R., \& McGuire, M. (1998). The intergovernmental context of local economic development. State and Local Government Review, 30, 150-164.

Akee, R. K., Splide, K. A., \& Taylor, J. B. (2014). Social and economic changes on American Indian reservations in California: an examination of twenty years of tribal government gaming. UNLV Gaming Research \& Review Journal, 18, 39-64.

Akee, R. K., \& Taylor, J. B. (2014). Social and economic change on American Indian reservations. Retrieved from http://static.squarespace.com/static/52557b58e4b0d4767401ce95/t/5379756c e4b095f55e75c77b/1400468844624/AkeeTaylorUSDatabook2014-05-15.pdf

Alderson, D. (2013). The Great Florida Seminole trail; Complete guide to Seminole Indian historic and cultural sites open to the public. Sarasota, FL: Pineapple Press.

Allison, M. T., Rivers, P. A., \& Fottler, M. D. (2007, 2/7/2007). Future public health delivery models for Native American tribes. Public Health, 121, 296307. http://dx.doi.org/10.1016/j.puhe.2006.11.005

American cowboy chronicles. (n.d.). http://www.americancowboychronicles.com/2017/01/the-first-americancowboys.html

Anderson, T., Benson, B., \& Flanagan, T. E. (2006). Self-determination: The other path for Native Americans. Redwood City, CA: Stanford University Press

Anderson, T. L. (Ed.). (1992). Property rights and Indian economies. Lanham, MD: Rowman \& Littlefield Publishers, Inc. 
Aufrecht, S. E. (1999). Missing Native American governance in American public administration literature. American review of public administration, 29, 370390

Aufrecht, S. E., \& Case, D. S. (2005). Indians 78, Washington State 0: Stories about Indians and the law. Public Administration Review, 4, 450-461.

Austin, A. (2013). Native Americans and jobs. Economic Policy Institute briefing paper, 1-37. Retrieved from https://www.epi.org/files/2013/NATIVEAMERICANS-AND-JOBS-The-Challenge-and-the-Promise.pdf

Baker, P. (1994). Tribal governance and economic development of American Indian Nations. Tribal College journal of American Indian higher education, 2. Retrieved from https://tribalcollegejournal.org/tribal-governance-economicdevelopment-american-indian-nations/

Benson, D. A., Lies, A., Okunade, A. A., \& Wunnava, P. V. (2009). Small business economics of the Lakota fund on the Native American Indian Reservations. IZA Discussion paper, 1-22. Retrieved from http://ftp.iza.org/dp3933.pdf

Bowers, E. (2003). The game has changed. Retrieved from https://www.semtribe.com/seminoletribune/Archive/2003/Seminole\%20Tribun e\%20 \%20January\%2017,\%202003.pdf

Brinkmann, P. (2013). IRS takes Dexter Lehtinen to federal court. Retrieved from https://www.bizjournals.com/southflorida/blog/2013/08/irs-takes-dexterlehtinen-to-federal.html

Broome, B., \& Broome, R. (2007). Native Americans: Traditional healing. Urologic Nursing, 27, 161-173.

Broward Bar. (2017). http://www.browardbar.org/wpcontent/uploads/barrister/2017/sept/seminole-tribecolaboration.pdf?utm_source=Digital+Barrister++September+2017\&utm_campaign=Barrister++August+2016\&utm_medium=email

Broward Women Lawyers. (2015). https://browardwomenlawyers.com/events/practicing-before-the-seminoletribe-of-florida-court-introduction-to-the-newest-court-system-in-florida/

Brown, A. (2018). Five spills, six months in operation: Dakota Access track record highlights unavoidable reality - pipelines leak. Retrieved from https://theintercept.com/2018/01/09/dakota-access-pipeline-leak-energytransfer-partners/ 
Bureau of Indian Affairs. (2013). Code of Federal Regulations (290). Washington, DC: Government Printing Office.

Cape sable seaside sparrow: species profile. (n.d.). Retrieved from https://www.nps.gov/ever/learn/nature/csss.htm

Carlisle Indian School Digital Resource Center. (n.d.). http://carlisleindian.dickinson.edu/teach/kill-indian-and-save-man-captrichard-h-pratt-education-native-americans

Carlos, A. M., \& Lewis, F. D. (2012, October). Exchange among Native Americans and Europeans before 1800: Strategies and interactions. Paper presented at the Canadian Network for Economic History, Baniff Alberta Canada. Retrieved from http://www.economichistory.ca/pdfs/2012/carloslewis.pdf

Cattelino, J. (2008). High stakes: Florida Seminole gaming and sovereignty. Durham, NC; Duke University Press; [Kindle version].

CBSMiami.com Team. (2012). IRS amps up Miccosukee tribe tax probe. Retrieved, from http://miami.cbslocal.com/2012/08/01/irs-amps-upmiccosukee-tribe-tax-probe/

Charmaz, K. (2014). Constructing grounded theory (2nd ed.). Thousand Oaks, CA: Sage Publications Inc.

Clarkson, G. (2007, May 1). Tribal bonds: Statutory shackles and regulatory restraints on tribal economic development. North Carolina Law Review, 85, 1009-1085. Retrieved from http://scholarship.law.unc.edu/cgi/viewcontent. cgi?article=4265\&context=nclr

Clarkson, G. (2008). Accredited Indians: Increasing the flow of private equity into Indian Country as a domestic emerging market. Law and Economics Working Papers, 1-40. Retrieved from https://repository.law.umich.edu/cgi/viewcontent.cgi?article=1083\&context=la w_econ_archive

Clarkson, G. (2018). The problem of dual-taxation in Indian Country: the billiondollar tax weevil. Tribal Business Journal, 1 Issue 98. Retrieved from http://tribalbusinessjournal.com/news/problem-dual-taxation-indian-countrybillion-dollar-tax-weevil/

Clayton, L. A., Knight Jr., V. J., \& Moore, E. C. (Eds.). (1993). The De Soto chronicles. Tuscaloosa, AL: The University of Alabama Press.

Cohen, K.: (1998). Native American medicine. ALTERNATIVE THERAPIES IN HEALTH AND MEDICINE, 4, 45-57. 
Colbourne, R. (2017) An understanding of Native American entrepreneurship, Small Enterprise Research, 24:1, 49-61

Colorlines. (2013). https://www.colorlines.com/articles/6-native-americanbasketball-facts-inspired-louisvilles-star-sisters

Corbin, J., \& Strauss, A. (1990). Grounded Theory Research; Procedures, Canons and Evaluative Criteria. Zeitscrift fur Soziologie, 19, 418-427. Retrieved from http://www.zfsonline.org/index.php/zfs/article/viewFile/2741/2278

Cornell, S., \& Kalt, J. P. (2005). Two approaches to economic development on American Indian reservations: One works, the other doesn't. Library of Congress, 1-25. Retrieved from https://www.honigman.com/media/site_files/111_imgimgjopna_200502_Approaches.pdf

Cornell, S., \& Kalt, J. P. (2007). Two approaches to the development of Native nations: One works, the other doesn't. In M. Jorgensen, Rebuilding Native nations: Strategies for governance and development. Tucson, AZ: The University of Arizona Press.

Cornell, S., \& Kalt, J. P. (Eds.). (1992). Reloading the dice: Improving the chances for economic development on American Indian reservations. What can tribes do? Strategies and institutions in American Indian economic development (pp. 2-51). Los Angeles, CA: American Indian Studies Center, University of California.

Corporate Charter of the Seminole Tribe of Florida. (1957). https://www.loc.gov/law/help/american-indian-consts/PDF/58060123.pdf

Cotterell, B. (2014, April 3). Florida legislature says no dice for casinos this year. Reuters. Retrieved from https://www.reuters.com/article/us-usa-floridacasinos/florida-legislature-says-no-dice-for-casinos-this-yearidUSBREA3227Z20140403

Covington, J. W. (1986). The State of Florida and the Florida Indians, 1954-1961. Tequesta (History Miami Museum), XLVI), 35-47. Retrieved from http://digitalcollections.fiu.edu/tequesta/files/1986/86_1_03.pdf

Creswell, J. W. (2003). Research design: qualitative, quantitative, and mixed method approaches (5th ed.). Thousand Oaks, CA; Sage Publications [Google Books]. Retrieved from http://books.google.com/books 
Crotty, M. (1998). The foundations of social research, meaning and perspective in the research process. Thousand Oaks, CA; Sage Publications [Google Play]. Retrieved from http://play.google.com/books

Cummings, S. L. (2001). Community economic development as progressive politics: Toward a grassroots movement for economic justice. Stanford Law Review, 54, 399-493. Retrieved from http://www.jstor.org.ezproxy.fiu.edu/stable/pdf/1229464.pdf

Darnell, S. C. (2010). Power, politics and "sport for development and peace": Investigating the utility of sport for international development. Sociology of sport journal, 54-75.

De la Merced, M. J. (2006). Florida's Seminole Tribe buys Hard Rock Cafes and Casinos. Retrieved from http://www.nytimes.com/2006/12/08/business/08rock.html

Feng-shui. (n.d.). In Dictionary.com. Retrieved from http://www.dictionary.com/browse/feng-shui?s=t

Diochon, M. C. (2003). Entrepreneurship and Community Economic Development. Montreal, Canada: McGill-Queen's University Press.

Douglas, M. S., \& Rothchild, J. (1987). Voice of the river. Sarasota, FL; Pineapple Press, Inc.; [Kindle]. Available from Amazon Kindle

Dube, S., \& Danescu, D. (2011). Supplemental Guidance: Public Sector Definition [Global Auditors' Guide]. Retrieved from https://na.theiia.org/standardsguidance/Public\%20Documents/Public\%20Sector\%20Definition.pdf

Dyllick, T., \& Muff, K. (2016). Clarifying the meaning of sustainable business: Introducing a typology from business-as-usual to true business sustainability. Organization \& Environment, 29(2), 156-174. https://doi.org/10.1177/1086026615575176

Economic Development Administration Fiscal Year 2016 Annual Report [Annual Report]. (2016). Retrieved from EDA-FY2016 Annual Report Full PDF: https://www.eda.gov/files/annual-reports/fy2016/EDA-FY2016-Annual-Reportfull.pdf

(Ed.). (2013). Seminole chairman, princesses star at Florida folk heritage awards. The Seminole Tribune. Retrieved from http://seminoletribune.org/seminolechairman-princesses-star-at-florida-folk-heritage-awards/ 
Elkington, J. (1999). Enter the triple bottom line. In Cannibals with forks (pp. 116). [pdf]. Retrieved from http://www.johnelkington.com/archive/TBLelkington-chapter.pdf

Esterberg, K. G. (2002). Qualitative methods in social research. Boston, MA: McGraw-Hill.

Etemad, H., Wright, R. W., \& Dana, L. P. (2001). Symbiotic International Business Networks: Collaboration between small and large firms. Thunderbird International Business Review, 43, 481-499.

Ethnographic studies can inform agencies' actions [Staff study]. (2003). Retrieved from GAO: https://www.gao.gov/assets/90/80115.pdf

Every Student Succeeds Act, 114-95 20 USC $6301 \S 8030$ et seq. (114th Congress 2015).

FDOT-Native American Coordination. (n.d.). http://www.fdot.gov/environment/na\%20website\%20files/Laws.shtm

Ferrell, J. (2017). Seminole Tribe suing Jacksonville 'electronic gambling parlors'. Retrieved from http://www.firstcoastnews.com/article/news/local/seminoletribe-suing-jacksonville-electronic-gambling-parlors/77-499310371

Fineout, G. (2017, January 20). No deal as Florida appeals Seminole Tribe blackjack ruling. Orlando Sentinel. Retrieved from http://www.orlandosentinel.com/news/politics/os-seminole-gambling-lawsuit20170120-story.html

Fischler, R. S. (1980). Protecting American Indian children. Social Work, 341349.

Flaherty, C. (2015). Not up for debate? Retrieved from https://www.insidehighered.com/news/2015/09/15/sacramento-state-studentsays-she-was-kicked-out-class-arguing-native-americans-were

Florida Chamber of Commerce Advocacy Issues. (n.d.). http://www.flchamber.com/advocacy/issues/

Florida Governor's Office. (2016). Division of Pari-Mutuel Wagering Fiscal 20152016 (85th). Retrieved from Florida License: http://www.myfloridalicense.com/dbpr/pmw/documents/AnnualReports/Annual Report-2015-2016--85th--20170125.pdf

Florida Statutes. (2017).

http://leg.state.fl.us/STATUTES/index.cfm?App_mode=Display_Statute\&URL $=0200-0299 / 0285 / 0285 . \mathrm{html}$ 
Flyvbjerg, B. (2006, April 1). Five misunderstandings about case-study research. Qualitative Inquiry, 12, 219-245. https://doi.org/ 10.1177/1077800405284363

Foreman, G. (1934). The five civilized tribes. Norman, OK: University of Oklahoma Press.

Frank, S. (2016). Seminole Tribe brings excellence to water and wastewater treatment. Treatment Plant Operations. Retrieved from https://www.tpomag.com/editorial/2016/04/seminole_tribe_brings_excellence _to_water_and_wastewater_treatment

Franklin, K. (2012). Miccosukees blame former lawyer for owing $\$ 26$ million to IRS. Retrieved from https://www.nbcmiami.com/news/local/MiccosukeesBlame-Former-Lawyer-For-Owing-26-Million-139220469.html

Frederickson, H. G. (2005). The state of social equity in American public administration. National Civic Review, 31-38. Retrieved from https://oied.ncsu.edu/selc/wp-content/uploads/2013/03/The-State-of-SocialEquity-in-American-Public-Administration.pdf

Fukuyama, F. (2002). Social capital and development: The coming agenda. SAIS Review, XXII, 23-37.

Gallagher, P. B. (2010). The rise and fall of Chief Jim Billie. Retrieved from http://www.gulfshorelife.com/September-2010/The-Rise-and-Fall-of-ChiefJim-Billie/

Garcia-Roberts, G. (2012). Miccosukee casino ripping off winners? Gamblers sue the tribe for bingo taxes. Retrieved from https://www.miaminewtimes.com/news/miccosukee-casino-ripping-offwinners-gamblers-sue-the-tribe-for-bingo-taxes-6538666

Garrison, T. A., \& Dobbs, C. (2015). Worcester v. Georgia. Retrieved from http://www.georgiaencyclopedia.org/articles/government-politics/worcester-vgeorgia-1832

General, K. E. (n.d.). Treaty rights and the UN Declaration on the rights of Indigenous peoples. Retrieved from http://indianlaw.org/content/treaty-rightsand-un-declaration-rights-indigenous-peoples

Gillen, J. (2016, February 11). New gaming compact offers Florida biggest guaranteed share of any state, Seminoles say. Tampa Bay Times. Retrieved from http://www.politifact.com/florida/statements/2016/feb/11/seminole-tribeflorida/new-gaming-compact-offers-florida-biggest-guarante/

Given, L. M. (2016). 100 Questions (and answers) about qualitative research. Thousand Oaks, CA; Sage Publications; Retrieved from 
https://play.google.com/books/reader?id=29i5BgAAQBAJ\&printsec=frontcove r\&output=reader\&hl=en\&pg=GBS.PP1

Glaser, B. G., \& Strauss, A. L. (1967). Discovery of grounded theory, strategies for qualitative research. New York, NY; Routledge Publications; Retrieved from https://play.google.com/books/

Godfrey, M. C., \& Catton, T. (2011). Preserving their interests: The Seminole and Miccosukee Indians. In River of interests: Water management in South Florida and the Everglades, 1948-2010 (pp. 229-237). [Pdf]. Retrieved from http://141.232.10.32/docs/river_interest/031512_river_interests_2012_chap_1 5.pdf

Goetzmann, W., \& Koll, E. (2005). The history of corporate ownership in China: State patronage, company legislation, and the issue of control. Retrieved from National Bureau of Economic Research: http://www.nber.org/chapters/c10269.pdf

Goodman-Draper, J. (1994). The development of underdevelopment at Akwesasne: Cultural and economic subversion. American Journal of Economics and Sociology, 53, 40-56.

Gov. Scott: Agreement with Seminole Tribe ensures continued investments for Florida families. (2018). Retrieved from https://www.flgov.com/2018/04/18/gov-scott-agreement-with-seminole-tribeensures-continued-investments-for-florida-families/

Graham, L. M. (2004). An interdisciplinary approach to American Indian economic development. North Dakota Law Review, 80, 597-655.

Gurley, D., Novins, D. K., Jones, M. C., Beals, J., Shore, J. H., \& Manson, S. M. (2001). Comparative use of biomedical services and traditional healing options by American Indian veterans. Psychiatric Services, 52, 68-74.

Hagan, W. T. (2013). American Indians (4th ed.). Chicago, IL: University of Chicago Press.

Hammer, J., \& Pivo, G. (2017). The triple bottom line and sustainable economic development theory and practice. Economic Development Quarterly, 31(1), 25-36.

Hansen, E. (2017). The forgotten minority in police shootings. Retrieved from https://www.cnn.com/2017/11/10/us/native-lives-matter/index.html

Hanushek, E. A., Ruhose, J., \& Woessmann, L. (2016). It pays to improve school quality. Education Next, 16+24. 
Harwood, R. (2015, December 14). Seminole 20-Year Compact Provides 'Stability and Certainty for the Long Term'. Indian Country Today. Retrieved from https://indiancountrymedianetwork.com/news/business/seminole-20year-compact-provides-stability-and-certainty-for-the-long-term/

Henry, N. (2018). Public administration and public affairs (13th ed.). New York, NY; Routledge Publications [Google Edition]. Retrieved from http://play.google.com/books

Herrera, C. (2016, May 22). The state of the Seminole tribe's compact with the Florida. Miami Herald. Retrieved from http://www.miamiherald.com/news/business/tourismcruises/article79199997.html

Hirschi, G., \& Jones, M. (2009). Affects of strategic leadership on business success- a cross-cultural analysis from a resource-based view. Management of Innovative Business \& Education Systems, 3, 1-18. Retrieved from http://ro.uow.edu.au/buspapers/450

Holm, T., Pearson, J. D., \& Chavis, B. (2003). Peoplehood: A model for the extension of sovereignty in American Indian studies. Wicazo Sa Review, 18, 7-24.

Hosmer, B., \& O'Neill, C. (2004). Native Pathways: American Indian culture and economic development in the twentieth century. Retrieved from http://www.jstor.org.ezproxy.fiu.edu/stable/j.ctt46nvxp

H.R. 4863, 109 Cong. (2006).

H.R. Doc. No. 465 at 331 (1969).

H.R. Rep. No. 1386 at 1 (1978).

H.R. Res. 331, 100th 2nd Session Cong., 331 H. Con. Res. 3311 (1988) (enacted).

Indian Child Welfare Act, H.R. Res. P.L. 95-608, 95th Cong., 92 Stat. 3069 Public Law 95-608 n/a (1978) (enacted).

Indian Claims Commission: Additional Findings, 73-A Okstate.edu 107 (Ft. Lauderdale FL 1977).

Indian Energy and Economic Development. (n.d.). https://www.bia.gov/asia/ieed/online-primers-economic-development-glance 
Indian Gaming Regulatory Act [Fact Sheet]. (2015). Retrieved from Indian Gaming Regulatory Act: https://www.nigc.gov/general-counsel/indian-gamingregulatory-act

Indian Law and Order Commission United States of America. (2013). Roadmap for making Native America safer: Report to the President and Congress of the United States [National Criminal Justice Reference Service publication]. Retrieved from National Criminal Justice Reference Service: https://www.aisc.ucla.edu/iloc/report/files/Chapter_4_Intergovernmental.pdf

Indigenous trade: The Southeast. (1997). In Encyclopedia.com. Retrieved from http://www.encyclopedia.com/history/news-wires-white-papers-andbooks/indigenous-trade-southeast

Jim Shore "State should continue the Seminole gaming compact". (2014, March 5,). Sun Sentinel. Retrieved from http://www.sun-sentinel.com/opinion/sfl-jimshore-state-should-continue-the-seminole-gaming-compact-20140305story.html

Johnson, T. M., \& Hamilton, J. (1995). Self-governance for Indian tribes: From paternalism to empowerment. Connecticut Law Review, 27, 1251-1279.

Juliano, A. C. (2004). What is the federal government's trust responsibility toward removed and unremoved Indian nations? Syracuse Journal of International Law and Commerce, 31, 71-81.

Kam, D. (2016). April 28. Retrieved from https://www.orlandoweekly.com/Blogs/archives/2016/04/28/floridas-legal-billsmount-over-gambling-dispute-with-seminole-tribe

Kam, D. (2018). Tribe, Legislative leaders huddle on gambling. Retrieved from https://www.law.com/dailybusinessreview/2018/02/14/tribe-legislative-leadershuddle-on-gambling/?slreturn=20180307234637

Kersey, H. A. (2001, September 22). The Havana connection. The American Indian Quarterly. Retrieved from https://www.thefreelibrary.com/The+Havana+connection.-a093009071

Kersey, Jr., H. A. (1992). The Miccosukees: Florida's oldest "new tribe". Forum: The Magazine of the Florida Humanities Council, 16-23.

Kersey Jr., H. A. (1996). An assumption of sovereignty: Social and political transformation among the Florida Seminoles 1953-1979. Lincoln, NE: University of Nebraska Press. 
Kestin, S., Franceschina, P., \& Maines, J. (2007). Despite its wealth, the tribe continues to get lots of federal help. Retrieved from http://www.sunsentinel.com/news/sfl-semgrantspnnov29-story.html

King, X. T., \& Begay Jr., M. A. (2003). Promoting strategic thinking in American Indian leaders. Indigenous Nations Studies Journal, 4, 53-67.

Klas, M. E. (2014, February 4,). Conservative legislators say they support limited expansion of gambling. Miami Herald. Retrieved from http://www.miamiherald.com/news/local/community/miamidade/article1959972.html

Klas, M. E. (2015, December 7). Deal: Florida Gov. Rick Scott signs \$3 billion gambling compact with Seminole Tribe. Miami Herald. Retrieved from http://www.miamiherald.com/news/politics-government/statepolitics/article48541885.html

Klas, M. E. (2017, July 5). Florida hits $\$ 340$ million jackpot by settling gambling dispute with Seminole Tribe. Miami Herald. Retrieved from http://www.miamiherald.com/news/local/community/broward/article159823589 .html

Koithan, M., \& Farrell, C. (2010). Indigenous Native American healing traditions. The Journal for Nurse Practitioners, 6, 477-478. http://dx.doi.org/10.1016/j.nurpra.2010.03.016

Koppisch, J. (2011, December 13). Why are Indian reservations so poor? A look at the bottom $1 \%$. Forbes. Retrieved from https://www.forbes.com/sites/johnkoppisch/2011/12/13/why-are-indianreservations-so-poor-a-look-at-the-bottom-1/\#5f7789e53c07

Kovach, M. (2009). Indigenous methodologies; characteristics, conversations, and contexts. Toronto, ON; University of Toronto Press Inc. [Kindle book]

Laws of the colonial and state governments relating to Indians and Indian affairs 1633-1831. (1832). Washington, DC: Thompson and Homans.

1LeBeau, T. A. (2001). Reclaiming reservation infrastructure: Regulatory and economic opportunities for tribal development. (The state of Native America and its unfolding self-governance). Stanford Law \& Policy Review, 12(2), 237-253.

Lomawaima, K. T., \& McCarty, T. L. (2002). When tribal sovereignty challenges democracy: American Indian education and the democratic ideal. American Educational Research Journal, 39, 279-305. 
Luton, L. S. (2010). Qualitative research approaches for public administration. Armonk, NY; M.E. Sharpe, Inc.; Retrieved from https://play.google.com/books

Macartney, S., Bishaw, A., \& Fontenot, K. (2013). Poverty rates for selected detailed race and Hispanic groups by state and place: 2007-2011. Retrieved from https://www.census.gov/prod/2013pubs/acsbr11-17.pdf

Madsen, B. D. (2007). The Northern Shoshoni (3rd ed.). Cladwell, ID: Caxton Press.

Mannes, M. (1995). Factors and events leading to the passage of the Indian Child Welfare Act. Child Welfare, 74, 264-282.

Marlowe, J. (2004). Part of the solution, or cogs in the system? The origins and consequences of trust in public administrators. American Society for Public Administration, 6, 93-113.

Masta, S. (2018). Strategy and resistance: How Native American students engage in accommodation in mainstream schools. Anthropology \& Education, 49, 21-35. https://doi.org/:10.1111/aeq.12231

Matten, D., Crane, A., \& Chapple, W. (2003, June 1). Behind the mask: Revealing the true face of corporate citizenship. Journal of Business Ethics, 45.

Maxwell, J. A. (2012). Qualitative research design: an interactive approach (3rd ed.). Thousand Oaks, CA; Sage Publications; Retrieved from https://play.google.com/books/reader?id=xAHCOmtAZd0C\&printsec=frontcov er\&output=reader\&hl=en\&pg=GBS.PR3

Meriam, L. (1928). The problem of Indian administration. Baltimore, MD: The Johns Hopkins Press.

Miccosukee Tribe accuses Collier officials of disrespect. (2018). Retrieved from http://www.nbc-2.com/story/35417032/miccosukee-tribe-accuses-collierofficials-of-disrespect

Miccosukee Tribe 'disappointed' by ruling on taxation of gaming per caps. (2018). Retrieved from https://www.indianz.com/IndianGaming/2018/06/05/miccosukee-tribedisappointed-by-ruling.asp

Miccosukee Tribe Reservation Areas. (n.d.). http://www.miccosukee.com/tribec/reservation-areas/ 
2Mika, K. (1995). Private dollars on the reservation: Will recent Native American economic development amount to cultural assimilation? New Mexico Law Review, 25, 23-34.

Mike Anderson Journal Staff. (2016). Dakota Access pipeline fight unites the seven Sioux nations. Retrieved from http://rapidcityjournal.com/news/local/dakota-access-pipeline-fight-unites-theseven-sioux-nations/article_9a746b78-f1fd-5f30-b5d5-cfde26c0642a.html

Miller, R. J. (1993). American Indian influence on the United States Constitution and its framers. American Indian Law Review, 18, 133-160.

Miller, R. J. (2012). Reservation "capitalism": Economic development in Indian country. Santa Barbara, CA: Praeger.

Nakashima, E., \& Tucker, N. (2002). Lost Trust: Billions go uncounted. Retrieved from http://www.washingtonpost.com/wp-dyn/articles/A25625-2002Apr21.html

National Center for Education Statistics. (2015). http://nces.ed.gov/ccd/tables/ACGR_RE_and_characteristics_2013-14.asp

National Congress of American Indians. (n.d.). http://www.ncai.org/about-ncai

National Congress of American Indians website. (2015). http://www.ncai.org/about-tribes

Native American Bank. (n.d.). http://www.nabna.com/about_us.php

Native American: Indigenous peoples of Canada and United States. (n.d.). Retrieved from https://www.britannica.com/topic/Native-American/NativeAmerican-history

Naude, W. (2013). Entrepreneurship and economic development: Theory, evidence and policy [IZA Discussion Paper No. 7507]. Retrieved from SSRN: https://ssrn.com/abstract=2314802

Nike. (2013). https://news.nike.com/nike-n7

Nissenbaum, P., \& Shadle, P. (1991). Evaluating land use proposals: A comprehensive system for the Puyallup Tribe of Indians [Project Report Series]. Retrieved from Harvard Project on American Indian Economic Development: https://hpaied.org/sites/default/files/publications/PRS91-2.pdf

No. 16-17109 United States Court of Appeals for the Eleventh Circuit 11 (Southern District Court for the Southern District of Florida 2017). 
Nordheimer, J. (1970). Oil exploration a peril to Everglades. Retrieved from https://www.nytimes.com/1970/07/08/archives/oil-exploration-a-peril-toeverglades.html

Norris, T., Vines, P. L., \& Hoeffel, E. M. (2012). The American Indian and Alaska Native population: 2010 [U.S. Census Bureau]. Retrieved from Census Briefs: http://www.census.gov/prod/cen2010/briefs/c2010br-10.pdf

O'Connell, M. P. (2014). Fundamentals of contracting by and with Indian tribes. American Indian Law Journal, III, 159-226.

Office of Management and Budget. (n.d.). Table 1.1-Summary of Receipts, Outlays, and Surpluses or Deficits (-) 1789-2021 [Data file]. Retrieved from https://obamawhitehouse.archives.gov/omb/budget/Historicals

On common ground: Coming to an understanding. (n.d.). Retrieved from https://seminolemiccosukeepolitics.omeka.net/exhibits/show/creating-tribesin-florida/variants-of-recognition/on-common-ground

Ortiz, J. (2002). Tribal governance and public administration. Administration \& Society, 34(5), 459-481.

Parry, W. (2018). Hard Rock hires 3,000th worker for Atlantic City casino. Retrieved from https://www.wgauradio.com/news/hard-rock-hires-000thworker-for-atlantic-city-casino/7iyPNmvlzQ2vpLiUk5wLMK/

Pevar, S. L. (2012). The rights of Indians \& tribes (4th ed.). New York, NY: Oxford University Press.

Pittman, C., \& Waite, M. (2009). Paving paradise: Florida's vanishing wetlands and the failure of no net lass. Gainsville, FL; University Press of Florida; [Kindle version]. Retrieved from Amazon Kindle

Plotkin, M. J. (1993). Tales of a Shaman's apprentice, an ethnobotanist searches for new medicines in the rain forest. New York, NY: Penguin Group (USA) LLC.

Portal, P. (2018). It was once part of the Everglades. Now Miami-Dade wants to use it for a highway. Retrieved from https://www.miamiherald.com/news/local/environment/article212824854.html

Public Law 105-313. (1998). Retrieved from https://www.congress.gov: https://www.congress.gov/105/plaws/publ313/PLAW-105publ313.pdf

Putnam, R. D. (1993, March 21). The prosperous community: Social capital and public life. The American Prospect, 4(13), 1-11. Retrieved from http://staskulesh.com/wp-content/uploads/2012/11/prosperouscommunity.pdf 
Ragsdale, J. W. (1991). Indian reservations and the preservation of tribal culture: Beyond wardship to stewardship. UMKC Law Review, 59(3), 503-554.

rezballaffiliate.com. (n.d.). https://rezballaffiliate.com/pages/custom

Rice, Z. C. (2017). The Dakota Access pipeline sprung 2 new leaks. Retrieved from http://www.businessinsider.com/the-dakota-access-pipeline-sprung-2new-leaks-2017-5

Riley, N. S. (2016). The new trail of tears, how Washington is destroying American Indians. New York, NY; Encounter Books; Retrieved from https://play.google.com/books/

Rodrigues, C. A. (1990). When cross-cultural equals double cross. Administration \& Society, 22, 341-357.

Ronquillo, J. C. (2011). American Indian tribal governance and management: Public administration promise or pretense. Public Administration Review, 7(2), 285-292.

Rosica, J. (2016). January 25. Retrieved from http://floridapolitics.com/archives/199646-state-responds-to-seminole-tribefederal-lawsuit

Rosica, J. (2016). Seminole compact dies (again) in legislature. Retrieved from http://floridapolitics.com/archives/203662-203662

Rosica, J. (2017). Seminole Tribe buys former Trump Taj Mahal casino in NJ. Retrieved from http://floridapolitics.com/archives/233050-seminole-tribetrump-taj-mahal

Rosica, J. L. (2014, August 3). Gaming talks with Seminoles likely stuck until November vote. Tampa Bay Times. Retrieved from http://tbo.com/news/politics/gaming-talks-with-seminoles-likely-stuck-untilnovember-vote-20140803/

Rosser, E. (2005, 06/22/2005). This land is my land, this is your land: Markets and institutions for economic development on Native American land. Arizona law review, 47(2), 245-312.

Ruffing, L. T. (1976). Navajo Economic Development subject to cultural constraints. Economic Development \& Cultural Change, 24, 611-621. Chicago, IL; The University of Chicago Press Journals

Rumberger, R. W. (2004). Dropouts in America: Confronting the graduation rate crisis. Cambridge, MA; Harvard Education Press; (Kindle ed.). [Kindle]. Retrieved from Kindle 
S. Doc. No. Public Law 100-228 at 1 (1987).

S. Rep. No. $106-150$ at 1 (1999).

Safdar, K. (2012). Billy Cypress, ex-Miccosukee chairman, accused of embezzling $\$ 26$ million. Retrieved from https://www.huffingtonpost.com/2012/07/05/billy-cypress-miccosukee-chiefembezzling_n_1651666.html

Sainato, M. (2017). How Florida's Native Americans predicted and survived hurricanes. Retrieved from http://therealnews.com/t2/story:19991:HowFlorida\%27s-Native-Americans-Predicted-and-Survived-Hurricanes

Salinero, M. (2015, October 26). Seminole tribe sues Florida in midst of talks over gaming pact. Tampa Bay Times. Retrieved from http://www.tbo.com/news/politics/seminole-tribe-sues-florida-in-midst-of-talksover-gaming-pact-20151026/

Sanderfur, G. D., \& Liebler, C. A. (1997). The demography of American Indian families. Southern Demographic Association, 16, 95-114.

Santayana, G. (1905). The life of reason. New York, NY; Open Road Media; [Google eBook version]. Retrieved from http://books.google.com/books

Sarche, M., \& Spicer, P. (2008, 1/1/2008). Poverty and health disparities for American Indian and Alaska native children. Annals of the New York Academy of Sciences, 126-136.

Schreier, G. (2012). US court panel upholds ruling against Fla. tribe. Retrieved from https://www.cnbc.com/id/100172368

Scott, H. (2009). Grounded Theory Online. Retrieved from http://www.groundedtheoryonline.com/what-is-grounded-theory/

Seminole Board of Directors. (n.d.). http://www.semtribe.com/Government/BoardofDirectors.aspx

Seminole Constitution [Historical]. (1957). U.S. Department of the Interior: U.S. Government

Seminole History. (n.d.). Retrieved from http://www.semtribe.com/History/IndianRemoval.aspx

Seminole Pride Beef. (n.d.). http://www.stofinc.com/sempridebeef/seminolecattle-history/ 
Seminole Tribune. (n.d.).

https://www.semtribe.com/seminoletribune/archive/40anniversary/interview_bi llie.html

Siniard, D. (n.d.). Brief Background on Seminoles. Retrieved from http://florida.lostsoulsgenealogy.com/seminoles/seminolebackground.htm

Smith, D. H. (2000). Modern Tribal Development. Walnut Creek, CA: Altamira Press.

Smith, N. (2016). Seminole Tribe can keep dealing blackjack, baccarat until 2030. Retrieved from http://sunshinestatenews.com/story/seminole-tribe-cankeep-dealing-blackjack-baccarat-until-2030

Smith, N. (2016). Seminole Tribe v. Florida to begin Monday in Tallahassee Federal court. Retrieved from http://sunshinestatenews.com/story/seminoletribe-v-florida-lawsuit-begin-federal-court-tallahassee

Soler, E. (2013). Annual Shootout Celebrates Seminole Victory. Retrieved from https://www.semtribe.com/SeminoleTribune/Archive/2013/SeminoleTribune_ March\%2029_2013v2.pdf

Sortal, N. (2015, June 24). Seminole Tribe says state voided gambling agreement. Sun-Sentinel. Retrieved from http://www.sun-sentinel.com/local/flseminole-compact-void-20150624-story.html

Stake, R. E. (1995). The art of case study research. Thousand Oaks, California: Sage Publications.

StarTalk with Neil deGrasse Tyson. (10/23/2017, 10/23/2017). Katie Couric [Video file]. Retrieved from https://www.youtube.com/watch?v=6MJi2r1RUuA

Steidman, J. (2006). Judge thrown off decade-old Indian Trust case. Retrieved from http://www.nbcnews.com/id/13816812/ns/politics/t/judge-thrown-decadeold-indian-trust-case/\#.W2iPsIVKhhE

Stein, J. (2005). Contempt from court: The blistering eloquence of Judge Royce C. Lamberth. Retrieved from https://www.motherjones.com/politics/2005/09/contempt-court-blisteringeloquence-judge-royce-c-lamberth/

Strauss, A., \& Corbin, J. (1998). Basics of qualitative research: second edition: techniques and procedures for developing grounded theory (2 ed.). Thousand Oaks, CA: Sage.

Strickland, R. (1986). Genocide-at-law: An historic and contemporary view of the Native American experience. University of Kansas Law Review, 34, 713-755. 
Success Stories: U.S. Economic Development Administration. (July 2017). https://www.eda.gov/success-stories/edd/stories/swreda.htm

Support for the Improvement of Government-to-Government Relations with the Miccosukee Tribe of Indians of Florida, H.R. 4863, 109th Cong. (2006).

Sznycer, D., Al-Shawaf, L., Bereby-Meyer, Y., Curry, O. S., De Smet, D., Ermer, E., ... Tooby, J. (2017). Cross-cultural regularities in the cognitive architecture of pride. Proceedings of the National Academy of Sciences, 114(8), 1874-1879. doi:10.1073/pnas.1614389114

Tavory, I., \& Timmermans, S. (2014). Abductive analysis: theorizing qualitative research. Chicago, IL; The University of Chicago Press; [Google eBook]. Retrieved from http://play.google.com/books

Thaji, J. (2015, March 10). Seminole Tribe's 1.6 billion expansion hinges on fate of gaming compact. Tampa Bay Times. Retrieved from http://www.tampabay.com/news/business/economicdevelopment/seminoletribes-16-billion-expansion-hinges-on-fate-of-gaming-compact/2220780

The American Presidency Project. (n.d.). http://www.presidency.ucsb.edu/ws/?pid $=43130$

The economy of youth sports. (2015). Retrieved from https://ufonline.ufl.edu/infographics/youth-sports/

The multiplier effect. (n.d.). Retrieved from http://www.economicsonline.co.uk/Managing_the_economy/The_multiplier_ef fect.html

Tiger, B., \& Kersey Jr., H. A. (2002). Buffalo Tiger: A life in the Everglades. Lincoln, NE: University of Nebraska Press.

Tribal Education Departments National Assembly. (2011). Tribal Education Departments Report. TEDNA Report (https://tedna.org/). Boulder, CO.

Tribal Transportation Planning. (n.d.). https://www.fhwa.dot.gov/planning/processes/tribal/index.cfm

Tribe: Compact benefits Florida: front \& center. (2015, March 17). Orlando Sentinel. Retrieved from http://www.orlandosentinel.com/opinion/os-ed-frontcenter-seminoles-allen-20150316-story.html 
Trosper, R. L. (1987). That other discipline: Economics and American Indian History. In C. G. Calloway (Ed.), New directions in American Indian history (pp. 199-222). Norman OK: University of Oklahoma Press.

Turkey Point units $6 \& 7 \mathrm{COL}$ application part 3 - environmental report [COL application environmental report]. (2010). Retrieved from NRC Gov docs: http://pbadupws.nrc.gov/docs/ML1335/ML13357A418.pdf

Uenuma, F., \& Fritz, M. (2011). Why the Sioux are refusing $\$ 1.3$ billion. Retrieved from http://www.pbs.org/newshour/updates/north_america-july-dec11blackhills_08-23/

United States of America - Native Americans. (2009). Retrieved from http://minorityrights.org/minorities/native-americans/

United States of America v. Sally Jim and Miccosukee Tribe of Indians of Florida, Case No. 14-22441-Civ-Altonaga/O'Sullivan Document 186 Entered on FLSD Docket 08/16/2016 7 (Southern District of Florida 2016).

US Department of Housing and Urban Development Office of Policy Development and Research. (2017). Housing needs of American Indians and Alaska Natives in tribal areas [Annual Report]. Retrieved from HUD: https://www.huduser.gov/portal/sites/default/files/pdf/HNAlHousingNeeds.pdf

U.S. Department of the Interior. (2016, June 8). Acting Assistant Secretary Roberts issues final regulation to strengthen implementation of the Indian Child Welfare Act, focusing on family unification [Press release]. Retrieved from Indian Affairs: https://www.indianaffairs.gov/sites/bia.gov/files/assets/public/news/pdf/idc1034237.pdf

U.S. planning 3rd FLA. tribe. (1961, December). Seminole Indian News, p. 1. Retrieved from http://www.miccosukeeseminolenation.com/fourth_edition1.htm

USET-CEDS. (n.d.). https://www.usetinc.org/wpcontent/uploads/bvenuti/RN\%20Economic\%20Development/FINAL\%20USET --\%20CEDS.pdf

3Van Otten, G. A., \& Vasquez, M. (1992). Economic development on Arizona's Native-American reservations. Journal of Cultural Geography, 136(1), 114.

Vinje, D. L. (1996). Native American economic development on selected reservations: A comparative analysis. The American Journal of Economics and Sociology, 55(4), 427-442. 
Von Aderkas, E. (2005). American Indians of the Pacific Northwest. Oxford, United Kingdom: Osprey Publishing.

Vrasidas, C. (2000). Constructivism versus objectivism. International Journal of Educational Telecommunications, 6, 339-362. Retrieved from http://vrasidas.com/wp-content/uploads/2007/07/continuum.pdf

Waggoner, G. S., Carter, A. R., Root, R. R., Schramm, D., Thorwardson, N. K., \& Titlow, B. (1981). Miccosukee State Indian Reservation, oil and gas leasing program, environmental assessment (EA). Retrieved from Haithi Trust Digital Library: https://catalog.hathitrust.org/Record/100976360

Wagner, J. M. (2008). Improving Native American access to Federal funding for economic development through partnerships with rural communities. American Indian Law Review, 32, 525-613.

Weatherford, J. (1991). Native roots: How the Indians enriched America. New York, NY: The Random House Publishing Group.

Weaver, J. (2010). Judge to rule on Miccosukee financial records. Retrieved from http://articles.sun-sentinel.com/2010-08-10/news/fl-irs-miccosukee20100810_1_single-tribal-member-sonia-e-o-donnell-billy-cypress

Weaver, J. (2010). Miccosukee tribe takes on IRS: Says no tax owed on income from west Miami-Dade casino. Retrieved from https://www.palmbeachpost.com/news/state--regional/miccosukee-tribetakes-irs-says-taxes-owed-income-from-west-miami-dadecasino/YYIZ1Dn1J0vwMok1T1atQO/

Weaver, J. (2010). The IRS alleging the Miccosukee tribe used armored vehicles to deliver up to $\$ 10$ million in cash from its Miccosukee resort \& gaming hall to hundreds of Indians without anyone reporting the money as taxable income. Retrieved from http://www.hotelonline.com/News/PR2010_2nd/Jun10_IRSMiccosukee.html

Weaver, J. (2016). Ousted chairman Cypress regains leadership of Miccosukee Tribe. Retrieved from https://www.miamiherald.com/news/local/article64576622.html

Weisman, B. R. (1999). Unconquered People: Florida's Seminole and Miccosukee Indians. Gainesville, FL: University Press of Florida.

Weiss, E. M. (2006). At U.S. urging, court throws Lamberth off Indian case. Retrieved from http://www.washingtonpost.com/wpdyn/content/article/2006/07/11/AR2006071101161_pf.html 
West, P. (1998). The enduring Seminoles: From alligator wrestling to casino gaming. Gainesville, FL: University Press of Florida.

Why the Sioux are refusing $\$ 1.3$ billion. (2013, August 24). PBS News Hour. Retrieved from https://www.pbs.org/newshour/arts/north_america-july-dec11blackhills_08-23

Wickman, P. R. (2015). Seminole 'cowboys'. Retrieved from http://seminoletribune.org/seminole-cowboys/

Wiedman, D. (2010). Global marketing of Indigenous culture: Discovering Native America with Lee Tiger and the Florida Miccosukee. American Indian Culture and Research Journal, 34(3), 1-26.

Wilkins, D. E., \& Stark, H. K. (2018). American Indian politics and the American political system (4th ed.). Lanham, MD: Rowman \& Littlefield.

Wilkinson, T. (2009). Indian land trust abuse and the woman who finally got US to pay up. Retrieved from

https://www.csmonitor.com/USA/2009/1210/p02s10-usgn.html

Williams, J. L. (2011). American Indian heritage month commemoration vs. exploitation: Economic development. Retrieved from http://www.historyandtheheadlines.abc-

clio.com/ContentPages/ContentPage. aspx?entryld=1171637\&currentSection $=1161468 \&$ productid $=5$

Wood, M. (1994). Indian land and the promise of native sovereignty: The trust doctrine revisited. Utah Law Review 1994(4), 1471-1570.

Wood, R. W. (2012). IRS wins fight with Native American tribe. Retrieved from https://www.forbes.com/sites/robertwood/2012/10/19/irs-wins-fight-withnative-american-tribe/\#63fddac2530c

Wood, R. W. (2012). Native Americans and tribes face unsettling tax issue. Retrieved from http://www.woodllp.com/Publications/Articles/pdf/Native_Americans_and.pdf

Woodrow, S. (2012). Growing economies in Indian country: Taking stock of progress and partnerships. Retrieved from https://www.federalreserve.gov/newsevents/conferences/GEIC-white-paper20120501.pdf

World Commission on Environment and Development. (1987). Report of the World Commission on Environment and Development: Our common future [UN GA ED Report]. Retrieved from UN Documents: http://www.undocuments.net/our-common-future.pdf 
Yarbrough, C. (2008). 1/16th Seminole Indian. Retrieved from http://www.charlesyarbrough.com/2008/12/116th-seminole-indian/

Yin, R. K. (2014). Case study research design and methods (5th ed.). Thousand Oaks, CA: Sage.

Zaferatos, N. C. (1998). Planning the Native American tribal community: Understanding the basis of power controlling the reservation territory. Journal of the American Planning Association, 64(4), 395-410.

Zhao, L., \& Roper, J. (2011). A Confucian approach to well-being and social capital development. Journal of Management Development, 30, 740-752. 
VITA

DIANE BENITEZ

Born, Detroit, Michigan

1993

A.S., Computer Programming and Applications Broward College

Davie, Florida

2009

B.A., Public Administration

Florida International University

Miami, Florida

2012

M.A., Public Administration

Florida International University

Miami, Florida

$2014-2018$

Doctoral Candidate

Florida International University

Miami, Florida

2015-2018

Adjunct Faculty

Miami Dade College, Kendall Campus

Miami, Florida

PUBLICATIONS AND PRESENTATIONS

- Presenter, American Society for Public Administration (ASPA) National Conference

- 2015: Presenter, Long term effects of displacement - U.S. Native American Reservations \& Haiti 